Policy Research Working Paper 3084

\title{
Major Trade Trends in East Asia What are their Implications
for Regional Cooperation and Growth?
}

\author{
Francis $\mathrm{Ng}$ \\ Alexander Yeats
}

The World Bank

Development Research Group

Trade

June 2003 


\section{Abstract}

This study's empirical findings have positive implications for further efforts to expand East Asian regional trade and cooperation initiatives. Since the mid-1980s regional intra-trade has grown at a rate roughly double that of world trade, and at a rate far higher than the intra-trade of the North America Free Tradc Agreement (NAFTA) member countries or the European Union. Evidence based on intra-industry trade ratios or statistics on international production sharing show economic linkages and the interdependence of East Asian economies have considerably strengthened over the past two decades. On a global scale, East Asia (excluding Japan) now originates 19 percent of world trade, which is approximately the same share as the NAFTA member countries.

This paper-a product of Trade, Development Research Group-is part of a larger effort in the group to study regional trade and growth prospects. Copies of the paper are available free from the World Bank, $1818 \mathrm{H}$ Street NW, Washington, DC 20433. Please contact Paulina Flewitt, room MC3-333, telephone 202-473-2724, fax 202-522-1159, email address pflewitt@worldbank.org. Policy Research Working Papers are also posted on the Web at http://econ.worldbank.org. Francis Ng may be contacted at fng@worldbank.org. June 2003. (93 pages)

The Policy Research Working Paper Series disseminates the findings of work in progress to encourage the exchange of ideas about development issues. An objective of the series is to get the findings out quickly, even if the presentations are less than fully polished. The papers carry the names of the authors and should be cited accordingly. The findings, interpretations, and conclusions expressed in this paper are entirely those of the authors. They do not necessarily represent the view of the World Bank, its Executive Directors, or the countries they represent.

Produced by Partnerships, Capacity Building, and Outreach 


\section{MAJOR 'TRADE TRENDS IN EAST ASIA}

What are Their Implications for Regional Cooperation and Growth?

Francis $\mathrm{Ng}$ and Alexander Yeats

Member, World Bank Trade Team

and

Consultant on Trade Issues

For the World Bank 



\title{
MAJOR TRADE TRENDS IN EAST ASIA
}

\author{
What are Their Implications for Regional Cooperation and Growth?
}

Francis $\mathrm{Ng}$ and Alexander Yeats*

\section{INTRODUCTION}

During the last decade major changes occurred in global markets that have important implications for East Asian countries' export and growth prospects. The North American Free Trade Agreement (NAFTA) liberalized barriers to the intra-trade of Canada, Mexico, and the United States, while similar regional arrangements expanded in both Latin America and Europe. The Uruguay Round agreement significantly altered conditions under which international trade is conducted. Among the Round's achievements were an average 40 percent reduction in industrial countries' tariffs, an agreement on the phase-out of the Multifibre Accord (MFA), non-tariff barriers on agricultural products were converted to tariffs and lowered, "voluntary" export restraints were abolished, and some progress was made in the liberalization of barriers to trade in services. Major changes also occurred within East Asia including a remarkable increase in the relative importance of machinery and electronics products in intra-regional trade, and a rapid expansion of international production sharing as reflected in trade in parts and components.

While many of these developments have positive implications for East Asia, there are some potentially negative aspects. Regional trade arrangements (RTAs) like NAFTA, MERCOSUR, or the extended European Union give momber countries preferential (discriminatory) access to each other's markets, which may displace East Asian and other nonmembers' exports. Similarly, the Uruguay Round's reduction of most-favored-nation (MFN) tariffs lowered, or eliminated, preferences some East Asian exporters received under some industrial countries' GSP programs. The phase-out of the MFA may have negative implications if East Asian countries are not fully competitive in what promises to be a drastically aitered trading environment for textile and clothing products.

Recognizing that improved export opportunities can make a significant contribution to regional economic growth, this investigation analyzes the economic implications of major trends in East Asia's trade. A primary objective is to supplement recent analyses, both within and outside the World Bank, which examined prospects for strengthening and extending East Asian regional cooperation and preferential trade arrangements (Asian Development Bank 2002). This study proceeds as follows. First, the importance and growth in East Asian intra-trade is compared to that for other major country groups, the major origins and destinations of East Asian regional trade are identified, and the product composition of this exchange is analyzed. Next, measures such as the "revealed" comparative advantage (RCA) index, trade intensity and complementarity indices, measures of trade diversification and competitiveness are employed to help assess East Asia's export performance and prospects for further cooperative efforts such as regional production sharing, or joint efforts to upgrade the quality of exports. These analyses often focus on the economic implications of regional trade in parts and components which has greatly increased economic linkages and the interdependence of East Asian countries.

\footnotetext{
- The authors are, respectively, a member of the World Bank's trade team and consultant to the World Bank on international trade issues. This paper was prepared as part of a larger World Bank initiative to analyze prospects for regional cooperation initiatives in East Asia. We would like to thank Milan Brahmbhatt and Kathie Krumm for comments and suggestions.
} 
Trade Trends 1

Global Implications of East Asian Trade Changes

Key Point

From 1975 to 2001, East Asia's share of global exports expanded more than three-fold (to just under 19 percent), and doubled from 1985 to 2001. The region presently originates about the same share of global exports as NAFTA. Intra-regional exports, expressed as a share of world trade, experienced an even sharper expansion rising more than six-fold during 1975-2001.

A question of considerable interest is how has the importance of emerging East Asian countries' global or regional trade changed relative to world trade, or to the trade of other major countries. ${ }^{1}$ If East Asian intra-trade expanded at a relatively faster pace than world trade this could have positive implications for initiatives to negotiate regional trade arrangements (RTAs), like MERCOSUR or the North American Free Trade Agreement, in East Asia. The potential importance of this point was underscored in a recent Asian Development Bank (2002, pp. 157-196) report that argued Asian RTAs could have important beneficial economic effects including increased levels of trade and welfare, as well as positive scale effects associated with increased market size. Also, regional trade arrangements continue to proliferate elsewhere. In the mid-1990s, approximately one-half of global trade in manufactured goods occurred within regional trade arrangements (Primo Braga and Yeats 1995), and the recent extensions of the European Union and other RTAs increased this share.

Table 1.1 provides summary statistics bearing on these points. Shown here are East Asian global exports for selected years over 1975 to 2001, along with corresponding information on the share of this exchange in world trade. For comparison, similar statistics are shown for several major comparator country groups, like the European Union (15), NAFTA, Latin America and the Caribbean, or South Asia. The memo item provides statistics on the value and global share of East Asian intra-trade, as well as on the region's trade with Japan, China, and all non-regional countries as a group. ${ }^{2}$

Two key points emerge from these statistics,

- The relative change in East Asian trade was far greater than that for any other comparator group. This is clearly the case whether comparisons are made over the full 1975-2001 interval, or for the more recent 1985-2001 period. From 1975 to 2001, East Asia's share of global trade expanded more than three-fold (to just under 19 percent), and doubled from 1985 to 2001. In contrast, the global trade shares of NAFTA rose by about one percentage point while the EU (15) was steadily declining in relative importance.

' Following the lead of Kawai and Urata (2002) emerging East Asia (hereafter just referred to as East Asia) includes; Brunei, Cambodia, China, Hong Kong, Indonesia, Korea, Lao PDR, Malaysia, Mongolia, Philippines, Singapore, Taiwan (China), Thailand and Vietnam. Where Japan plays a pivotal role in regional trade, as in the exchange of parts and components, it may be included in some of the analyses that follow in order to better illustrate factors underlying East Asian trade trends.

${ }^{2}$ Statistics on East Asian countries' trade were tabulated from the reported imports of their trading partners. One reason for this approach is the transshipment of a high share of China's exports through Hong Kong. As a result, China often is unable to accurately identify the final destinations of its exports in its own trade statistics. However, evidence suggests importing countries are better equipped to identify goods of Chinese origin that are transshipped through Hong Kong, or some other entrepot center. See Appendix 1 for a discussion of this, and other related technical problems, in East Asian trade statistics. 
- East Asia's intra-regional exports, expressed as a share of world trade, experienced an even greater expansion rising more than six-fold during 1975-2001. The 16 percent annual growth rate for this exchange far exceeded that for any other group listed in Table 1.1. These statistics clearly have positive implications for the formation of RTAs in East Asia since these countries have rapidly increased the relative importance of their mutual trade contacts.

Table 1. 1 The Relative IImportance of East Asia and Other Regions in World Trade

\begin{tabular}{|l|c|c|c|c|c|c|c|c|}
\hline \multirow{2}{*}{ Group } & \multicolumn{3}{|c|}{ Total Exports (\$billion) } & \multicolumn{3}{|c|}{ Share of World Trade (\%) } \\
\cline { 2 - 9 } & 1975 & 1985 & 1995 & 2001 & 1975 & 1985 & 1995 & 2001 \\
\hline Australia/ New Zealand & 14.7 & 32.6 & 70.1 & 84.6 & 1.8 & 1.6 & 1.4 & 1.3 \\
East Asia' & 44.5 & 186.2 & 839.0 & $1,194.4$ & 5.4 & 9.4 & 16.3 & 18.7 \\
ASEAN & 22.0 & 72.0 & 307.8 & 403.8 & 2.7 & 3.6 & 6.0 & 6.3 \\
European Union (15) & 32.5 .3 & 711.6 & $1,893.4$ & $2,194.8$ & 39.2 & 36.0 & 36.9 & 34.3 \\
Japan & 49.1 & 190.3 & 476.1 & 448.6 & 5.9 & 9.6 & 9.3 & 7.0 \\
Latin America & 45.3 & 115.8 & 245.3 & 382.1 & 5.5 & 5.9 & 4.8 & 6.0 \\
Middle East & 84.7 & 109.1 & 155.1 & 247.8 & 10.2 & 5.5 & 3.0 & 3.9 \\
NAFTA & 143.9 & 351.9 & 922.4 & $1,214.7$ & 18.0 & 17.8 & 18.0 & 19.0 \\
North Africa & 13.4 & 29.4 & 33.9 & 49.3 & 1.6 & 1.5 & 0.7 & 0.8 \\
Other Europe-Cent. Asia ${ }^{2}$ & 40.5 & 128.7 & 244.7 & 340.7 & 4.9 & 6.5 & 4.8 & 5.3 \\
South Asia & 6.2 & 16.5 & 52.0 & 70.3 & 0.7 & 0.8 & 1.0 & 1.1 \\
Sub-Saharan Africa & 28.9 & 52.8 & 74.7 & 101.2 & 3.5 & 2.7 & 1.5 & 1.6 \\
& & & & & & & & \\
MEMO ITEM & & & & & & & & \\
East Asian Intra-Trade & 8.0 & 44.1 & 314.5 & 418.0 & 1.0 & 2.2 & 6.1 & 6.5 \\
East Asia-Japan Trade & 11.3 & 35.3 & 118.7 & 144.9 & 1.4 & 1.8 & 2.3 & 2.3 \\
East Asia- China Trade & 0.4 & 5.9 & 43.5 & 83.5 &. & 0.3 & 0.8 & 1.3 \\
East Asia-Rest of World & 36.5 & 142.1 & 524.5 & 776.4 & 4.4 & 7.2 & 10.2 & 12.1 \\
& & & & & & & & \\
NAFTA Intra-Trade & 55.6 & 159.5 & 396.0 & 646.5 & 6.7 & 8.1 & 7.7 & 10.1 \\
EU (15) Intra-Trade & 200.2 & 416.9 & $1,168.5$ & $1,296.6$ & 24.1 & 21.1 & 22.7 & 20.2 \\
MERCOSUR Intra-Trade & 1.0 & 2.0 & 14.5 & 16.6 & 0.1 & 0.1 & 0.3 & 0.3 \\
ASEAN Intra-Trade & 2.5 & 11.3 & 64.6 & 74.2 & 0.3 & 0.6 & 1.3 & 1.2 \\
WORLD EXPORTS & 829.2 & $1,975.9$ & $5,137.3$ & $6,403.1$ & 100 & 100 & 100 & 100 \\
\hline
\end{tabular}

1 East Asia is defined here as consisting of: Brunei, Cambodia, China, Republic of Korea, Hong Kong, Indonesia, Lao PDR, Malaysia, Mongolia, Philippines, Singapore, Taiwan (China), Thailand, and Vietnam.

${ }^{2}$ The totals for this group exclude Western Europe.

${ }^{3}$ The totals are based on 1978 Chinese trade data since 1975 statistics were not ayailable from IMF records.

Source: International Monetary Fund Direction of Trade Statistics

Table 1.2 examines the data from a somewhat different perspective and focuses on the strongest relative gainers, and strongest relative losers, in world trade during the two longer-term periods, that is, 1975-2001 and 1985-2001. East Asia figures prominently among the former. In terms of both annual growth rates and global trade share changes, East Asia is involved in the three most buoyant directional trade flows with NAFTA intra-trade in a relatively distant fourth place. East Asian intra-trade, for 
example, grew at an annual rate of 16 percent since 1975, which was about 6 percentage points higher than the intra-trade of NAFTA. ${ }^{3}$ Sub-Saharan Africa and the Middle East registered the lowest annual growth rates for exports, and highest losses of global trade shares over 1975-2001. The Middle East poor performance is partially due to the OPEC price increases in the early 1970 s, and the subsequent erosion of energy prices over the last two decades, while the marginalization of Africa is part of a long-term trend dating back to the 1950 s.

Table 1.2 The Strongest Relative Gainers and Losers in Global Trade; 1975 to 2001

\begin{tabular}{|l|c|c|c|c|c|c|c|}
\hline \multirow{2}{*}{} & \multicolumn{4}{|c|}{ Share of World Exports (\%) } & \multicolumn{2}{c|}{$\begin{array}{c}\text { Annual Growth } \\
\text { Rate (\%) }\end{array}$} \\
\cline { 2 - 7 } Directional Trade Flow & \multicolumn{3}{|c|}{ Actual Value (\%) } & \multicolumn{2}{c|}{ Share Change } & \multicolumn{2}{c|}{$1975-$} \\
\cline { 2 - 7 } & 1975 & 1985 & 2001 & 2001 & 2001 & 2001 & 2001 \\
\hline Strong Relative Gainers & & & & & & & \\
East Asian Intra-Trade & 1.0 & 2.2 & 6.5 & 4.3 & 5.5 & 15.1 & 16.4 \\
East Asian Global Trade & 5.4 & 9.4 & 18.7 & 9.3 & 13.3 & 12.3 & 13.5 \\
East Asia - Rest of World & 4.4 & 7.2 & 12.1 & 4.9 & 7.7 & 11.2 & 12.5 \\
NAFTA Intra-Trade & 6.7 & 8.1 & 10.1 & 2.0 & 3.4 & 9.1 & 9.9 \\
Strong Relative Losers & & & & & & & \\
EU (15) Intra-Trade & 24.1 & 21.1 & 20.2 & -0.9 & -3.9 & 7.4 & 7.5 \\
Sub-Sahara Africa Global Trade & 3.5 & 2.7 & 1.6 & -1.1 & -1.9 & 4.2 & 5.0 \\
Middle East Global Trade & 10.2 & 5.5 & 3.9 & -1.6 & -6.3 & 5.2 & 4.2 \\
WORLD EXPORTS & 100.0 & 100.0 & 100.0 & -- & - & 7.6 & 8.2 \\
\hline
\end{tabular}

Source: International Monetary Fund Direction of Trade Statistics.

${ }^{3}$ In the recent 1995-2001 period, East Asian exports to China almost doubled and experienced the fastest rate of growth of any trade flow reported in Table 1.1. In part, this was due to several counter-cyclical monetary and fiscal policies adopted by China during the period of the financial crisis that increased, or stabilized, demand for other East Asian countries' exports. 
Trade Trends 2

What are the Geographic Destinations of East Asian Exports?

\section{$\underline{\text { Key Point }}$}

Over 1985-2001, the share of East Asia's exports to the region rose from 24 to 35 percent with Indonesia, Taiwan (China), Korea, and the Philippines experiencing significantly higher directional trade changes. This shift was, in part, due to the fact that global import demand in East Asia was more buoyant than in any other major market.

An important question concerning East Asian countries' trade is whether significant changes in the direction of this exchange occurred and, if so, what factors were responsible. ${ }^{4}$ Specifically, statistics in Table 1.1 show East Asian global exports expanded during 1985-2001 at an annual rate almost 5 percentage points above that for world trade. Were shifts in the direction of East Asian trade toward newer (faster growing) geographic markets responsible for these above average growth rates? Second, has there been a general relative shift in East Asian exports toward the region, or do the high intra-regional trade growth statistics in Table 1.1 largely reflect the experience of a few bigger countries?

Table 2.1 examines 1985-2001 changes in the geographic direction of individual East Asian country's exports. The table reports the global value of this exchange in 1985, 1995 and 2001, and also shows the share destined for major markets like the European Union (15), North American Free Trade Agreement (NAFTA), or South Asia. To help analyze this information, Table 2.1 also presents similar statistics for the combined exports of all 14 East Asian countries. Finally, the table's memo item provides two summary measures relating to the regional trade changes. The first is the 1985-2001 change in the share of East Asia's exports destined for each major market, while the second is the annual growth rate of that market's global imports. Ideally, an East Asian country would want to see its exports shifting toward destinations that are experiencing above average import growth rates.

Table 2.1 indicates significant changes occurred in the general direction of East Asia's exports. Over 1985-2001, the share of exports going to other East Asian countries rose by over 11 percentage points (from 23.7 to 35 percent), while East Asia had the highest annual global import growth rate (11.6 percent). Although the relatively high import demand contributed to the strengthening of intra-regional trade, East Asia generally increased its import shares for most major traded products (see Trade Trends 8 that follows). Among the larger East Asian exporters, China, Indonesia, Republic of Korea, Philippines, and Taiwan (China) experienced major competitive share gains in regional markets

Two additional developments relating to Asia should be noted. First, ASEAN appears to have played a relatively minor role in the expansion of East Asian intra-trade trade. This is reflected in the fact the share of all regional countries' exports to ASEAN increased by little more than a percentage point. Second, a sizeable decline (almost 7 percentage points) occurred in the share of East Asia's exports going to Japan. The latter's longer-termi economic and financial problems were, no doubt, contributing factors.

\footnotetext{
${ }^{4}$ On strategic grounds there are reasons why a country should be concerned about the direction of its trade. For example, prior to World War II the United States initiated studies to determine how an outbreak of hostilities might affect imports of strategic materials 'from geographically remote areas. More recent investigations stress the need for countries to diversify the origins and destinations of their trade to avoid unfavorable monopoly effects associated with excessive concentration (see, among others, Hufbauer and O'Neill 1966, or Yeats (1990)). Geographic diversification has also been advised as a means of mitigating effects of unfavorable economic developments within a single major market. Countries whose recent trade was strongly oriented toward Germany or Japan probably were negatively affected by the persistent depressed economic conditions in these markets.
} 
Table 2. 1 The Geographic Destinations of East Asian Exports; 1985, 1995, 2000

\begin{tabular}{|c|c|c|c|c|c|c|c|c|c|c|c|c|}
\hline \multirow[b]{3}{*}{ East Asian Country } & \multirow[b]{3}{*}{ Year } & \multirow{3}{*}{$\begin{array}{c}\text { Global } \\
\text { Exports } \\
\text { (\$ Million) }\end{array}$} & \multicolumn{10}{|c|}{ Share of Total Exports Destined For (\%) } \\
\hline & & & \multirow{2}{*}{$\begin{array}{c}\text { East } \\
\text { Asia* }\end{array}$} & \multicolumn{2}{|c|}{ Of which: } & \multirow[b]{2}{*}{ Japan } & \multirow[b]{2}{*}{ EU (15) } & \multirow[b]{2}{*}{ NAFTA } & \multirow{2}{*}{$\begin{array}{c}\text { Australia/ } \\
\text { New Zealand }\end{array}$} & \multirow{2}{*}{$\begin{array}{l}\text { South } \\
\text { Asia }\end{array}$} & \multirow{2}{*}{$\begin{array}{c}\text { Sub-Sahara } \\
\text { Africa }\end{array}$} & \multirow{2}{*}{$\begin{array}{l}\text { Rest of } \\
\text { World }\end{array}$} \\
\hline & & & & China & ASEAN & & & & & & & \\
\hline \multirow[t]{3}{*}{ Brunei } & 1985 & 2,864 & 32.2 & 0.0 & 20.7 & 66.6 & 1.2 & 0.1 & 0.0 & 0.0 & 0.0 & 0.0 \\
\hline & 1995 & 2,573 & 37.0 & 0.0 & 20.4 & 52.2 & 8.2 & 1.7 & 0.7 & 0.0 & 0.1 & 0.2 \\
\hline & 2001 & 3,632 & 32.8 & 4.1 & 16.3 & 46.7 & 1.5 & 11.7 & 7.0 & 0.1 & 0.0 & 0.2 \\
\hline \multirow[t]{3}{*}{ Cambodia } & 1985 & 8 & 44.8 & 7.8 & 37.0 & 2.6 & 0.0 & 3.9 & 0.0 & 0.1 & 0.0 & 48.5 \\
\hline & 1995 & 393 & 70.1 & 1.5 & 63.1 & 1.9 & 14.5 & 1.6 & 0.1 & 7.7 & 0.1 & 4.0 . \\
\hline & 2001 & 1,719 & 10.6 & 2.0 & 6.8 & 3.8 & 24.1 & 60.1 & 0.2 & 0.0 & 0.3 & 0.9 \\
\hline \multirow[t]{3}{*}{ China } & 1985 & 31,356 & 34.7 & 0.0 & 10.5 & 20.8 & 10.0 & 14.7 & 1.2 & 1.4 & 1.2 & 15.9 \\
\hline & 1995 & 232,623 & 39.0 & 0.0 & 4.5 & 15.4 & 13.9 & 22.7 & 1.6 & 0.9 & 0.5 & 6.0 \\
\hline & 2001 & 415,879 & 30.7 & 0.0 & 5.0 & 13.9 & 15.3 & 29.5 & 1.6 & 0.9 & 1.1 & 6.9 \\
\hline \multirow[t]{3}{*}{ Hong Kong } & 1985 & 24,071 & 27.6 & 19.8 & 4.6 & 3.2 & 18.1 & 40.4 & 2.5 & 0.9 & 0.6 & 6.8 \\
\hline & 1995 & 55,742 & 35.9 & 15.4 & 15.7 & 4.9 & 24.1 & 21.5 & 1.8 & 2.1 & 1.7 & 8.1 \\
\hline & 2001 & 59,682 & 35.2 & 15.8 & 14.2 & 2.4 & 26.3 & 19.2 & 1.5 & 4.0 & 1.6 & 9.8 \\
\hline \multirow[t]{3}{*}{ Indonesia } & 1985 & 19,684 & 9.9 & 1.7 & 2.0 & 51.8 & 7.5 & 25.5 & 1.5 & 0.6 & 0.0 & 3.1 \\
\hline & 1995 & 47,885 & 25.1 & 4.3 & 5.9 & 29.7 & 16.9 & 18.0 & 2.6 & 1.4 & 0.4 & 5.9 \\
\hline & 2001 & 63,149 & 27.2 & 6.2 & 7.6 & 23.6 & 15.6 & 19.2 & 3.7 & 2.9 & 1.3 & 6.7 \\
\hline \multirow[t]{3}{*}{ Korea } & 1985 & 25,207 & 10.2 & 0.0 & 5.2 & 16.4 & 11.5 & 47.7 & 1.7 & 1.8 & 0.6 & 10.1 \\
\hline & 1995 & 117,907 & 34.2 & 8.7 & 13.8 & 14.7 & 12.7 & 24.2 & 1.8 & 1.6 & 1.5 & 9.4 \\
\hline & 2001 & 163,645 & 34.1 & 14.3 & 10.0 & 10.5 & 12.0 & 26.7 & 1.8 & 1.7 & 2.0 & 11.2 \\
\hline \multirow[t]{3}{*}{ Laos } & 1985 & 22 & 76.6 & 43.8 & 30.0 & 5.5 & 5.1 & 3.2 & 4.7 & 0.3 & 0.7 & 3.9 \\
\hline & 1995 & 345 & 55.1 & 1.9 & 47.7 & 8.6 & 29.6 & 3.9 & 0.0 & 0.0 & 0.0 & 2.7 \\
\hline & 2001 & 364 & 60.3 & 2.0 & 56.9 & 1.9 & 32.7 & 1.7 & 0.3 & 0.1 & 0.0 & 3.0 \\
\hline \multirow[t]{3}{*}{ Malaysia } & 1985 & 17,947 & 38.1 & 1.1 & 26.5 & 24.2 & 13.1 & 14.1 & 1.6 & 4.1 & 0.5 & 4.2 \\
\hline & 1995 & 86,288 & 43.6 & 2.4 & 30.6 & 12.2 & 13.1 & 22.8 & 1.8 & 2.4 & 0.3 & 3.8 \\
\hline & 2001 & 111,429 & 42.0 & 5.6 & 24.4 & 11.5 & 12.9 & 23.9 & 2.4 & 2.3 & 0.5 & 4.6 \\
\hline \multirow[t]{3}{*}{ Mongolia } & 1985 & 94 & 4.1 & 2.1 & 1.9 & 8.1 & 15.0 & 4.0 & 0.0 & 0.1 & 0.8 & 68.0 \\
\hline & 1995 & 380 & 29.2 & 26.5 & 0.0 & 23.8 & 10.1 & 6.7 & 0.0 & 0.1 & 0.0 & 30.2 \\
\hline & 2001 & 489 & 49.6 & 49.0 & 0.1 & 2.2 & 8.1 & 31.2 & 0.0 & 0.3 & 0.2 & 8.5 \\
\hline
\end{tabular}


Table 2.1 Continued.

\begin{tabular}{|c|c|c|c|c|c|c|c|c|c|c|c|c|}
\hline \multirow[b]{3}{*}{ East Asian Country } & \multirow[b]{3}{*}{ Year } & \multirow{3}{*}{$\begin{array}{c}\text { Global } \\
\text { Exports } \\
\text { (\$ Million) }\end{array}$} & \multicolumn{10}{|c|}{ Share of Total Exports Destined For (\%) } \\
\hline & & & \multirow{2}{*}{$\begin{array}{l}\text { East } \\
\text { Asia* }\end{array}$} & \multicolumn{2}{|c|}{ Of which: } & \multirow[b]{2}{*}{ Japan } & \multirow[b]{2}{*}{$\mathrm{EU}(15)$} & \multirow[b]{2}{*}{ NAFTA } & \multirow{2}{*}{$\begin{array}{c}\text { Australial } \\
\text { New Zealand }\end{array}$} & \multirow{2}{*}{$\begin{array}{l}\text { South } \\
\text { Asia }\end{array}$} & \multirow{2}{*}{$\begin{array}{l}\text { Sub-Sahara } \\
\text { Africa }\end{array}$} & \multirow{2}{*}{$\begin{array}{l}\text { Rest of } \\
\text { World }\end{array}$} \\
\hline & & & & China & ASEAN & & & & & & & \\
\hline \multirow[t]{3}{*}{ Philippines } & 1985 & 6,112 & 17.5 & 1.6 & $\overline{8.4}$ & 20.5 & 16.5 & 39.6 & 1.9 & 0.5 & 0.0 & 3.4 \\
\hline & 1995 & 19,780 & 23.5 & 1.4 & 11.4 & 17.7 & 15.5 & 39.6 & 1.1 & 0.2 & 0.0 & 2.4 \\
\hline & 2001 & 42,870 & 34.4 & 4.5 & 13.4 & 15.0 & 16.1 & 31.2 & 0.8 & 0.2 & 0.1 & 2.2 \\
\hline \multirow[t]{3}{*}{ Singapore } & 1985 & 17,199 & 35.1 & 1.4 & 22.1 & 9.3 & 10.8 & 26.8 & 5.0 & 4.7 & 0.5 & 7.7 \\
\hline & 1995 & 88,629 & 44.0 & 3.8 & 23.0 & 7.7 & 14.8 & 22.9 & 2.4 & 2.3 & 0.9 & 5.0 \\
\hline & 2001 & 93,268 & 44.8 & 5.5 & 22.4 & 5.8 & 14.7 & 18.6 & 2.7 & 5.1 & 1.2 & 7.1 \\
\hline \multirow[t]{3}{*}{ Taiwan, China } & 1985 & 33,610 & 14.9 & 0.0 & 5.9 & 10.2 & 10.2 & 55.9 & 2.9 & 0.5 & 0.5 & 5.0 \\
\hline & 1995 & 122,940 & 39.9 & 12.0 & 12.2 & 11.7 & 13.5 & 27.0 & 2.0 & 0.4 & 0.3 & 5.1 \\
\hline & 2001 & 151,981 & 41.1 & 18.0 & 11.1 & 9.3 & 14.7 & 27.1 & 1.3 & 0.9 & 0.2 & 5.3 \\
\hline \multirow[t]{3}{*}{ Thailand } & 1985 & 7,787 & 25.4 & 3.4 & 14.4 & 13.3 & 22.4 & 21.1 & 1.9 & 2.5 & 3.9 & 9.5 \\
\hline & 1995 & 54,837 & 32.0 & 2.9 & 19.7 & 18.5 & 16.6 & 23.4 & 1.7 & 1.1 & 1.4 & 5.3 \\
\hline & 2001 & 72,746 & 33.5 & 6.5 & 17.0 & 14.2 & 15.7 & 24.0 & 2.4 & 1.5 & 1.7 & 7.0 \\
\hline \multirow[t]{3}{*}{ Vietnam } & 1985 & 407 & 44.9 & 0.0 & 20.3 & 16.1 & 5.8 & 0.4 & 2.0 & 1.7 & 1.0 & 28.0 \\
\hline & 1995 & 6,222 & 30.8 & 5.3 & 15.2 & 27.6 & 24.5 & 4.4 & 3.9 & 0.3 & 0.7 & 7.8 \\
\hline & 2001 & 14,894 & 29.2 & 6.8 & 15.3 & 17.5 & 26.8 & 8.8 & 8.2 & 0.5 & 1.1 & 7.8 \\
\hline \multirow[t]{3}{*}{ All Above Countries } & 1985 & 186,156 & 23.7 & 3.2 & 10.2 & 19.0 & 12.0 & 33.0 & 2.2 & 1.7 & 0.7 & 7.9 \\
\hline & 1995 & 839,045 & 37.5 & 5.2 & 13.7 & 14.1 & 14.8 & 23.4 & 1.8 & 1.3 & 0.7 & 6.0 \\
\hline & 2001 & $1,194,401$ & 35.0 & 7.0 & 11.5 & 12.1 & 15.3 & 25.9 & 2.0 & 1.7 & 1.1 & 7.1 \\
\hline MEMO ITEM & & & & & & & & & & & & \\
\hline $\begin{array}{l}\text { East Asian Countries } \\
\text { Export Share Change }\end{array}$ & $\begin{array}{l}1985- \\
2001\end{array}$ & -- & 11.3 & 3.8 & 1.3 & -6.9 & 3.3 & -7.1 & -0.2 & 0.0 & 0.4 & -0.8 \\
\hline $\begin{array}{l}\text { Major Market Import } \\
\text { Growth Rate }(\%)\end{array}$ & & -- & 11.6 & 10.2 & 12.1 & 6.4 & 8.1 & 8.3 & 6.8 & 7.1 & 4.9 & 6.9 \\
\hline
\end{tabular}

* Brunei, Cambodia, China, Republic of Korea, Hong Kong, Indonesia, Lao PDR, Malaysia, Mongolia, Philippines, Singapore, Taiwan (China), Thailand, Vietnam

Source: IMF Direction of Trade statistics. 
One surprising observation is decline in the share of several East Asian countries (Philippines, Taiwan, Hong Kong, and Korea) exports going to NAFTA, which had a relatively high growth rate (8.3 percent annually) for global imports. Previous empirical analyses projected NAFTA preferential tariffs, which discriminate against non-member countries, would cause some diversion (mainly by Mexico) of East Asian exports to North America, and Table 2.1 suggests this occurred (Safadi and Yeats, 1996).

\section{Trade Trends 3 \\ Does Size Matter?}

\section{$\underline{\text { Key Point }}$}

The five largest regional exporters account for 80 percent of East Asian intra-trade. At the other extreme, the five smallest regional traders, namely, Brunei, Cambodia, Lao PDR, Mongolia and Vietnam have a combined regional export share under 2 percent. If size is measured by gross domestic product somewhat greater inequalities are observed as China alone accounts for about 43 percent of regional $G D P$, as opposed to its 30 percent share of intra-regional trade.

If countries that are engaged in regional trade differ markedly in their economic size this potentially could have negative implications for perceptions concerning the benefits of this exchange. In cases, changes in the macroeconomic, fiscal, or monetary policies of a large country have had major adverse effects on smaller RTA members. As an example, Brazil is the dominant member of the original Latin American MERCOSUR agreement (other original members include Argentina, Paraguay and Uruguay) with a GDP two and one-half times larger than that of the three smaller members combined, and a population almost four times greater. Brazil's major devaluation of the Real in the late 1990s resulted in significant export losses for Argentina, whose own currency was then tied to the United States dollar. This chain of events contributed to Argentina's present economic and financial problems.

Some analysts have also argued that significant differences in the size of intra-regional trade flows can potentially have negative effects for some partner countries if resources are drawn disproportionately to areas where production for export is relatively high (see Jabar 1971, or Healey 1977). The unequal sharing of benefits due to disparities in regional trade shares may have contributed to the collapse of the Latin Americas Free Trade Area (LAFTA) and original Andean Pact agreement (Viatsos 1978). In the case of the latter, one country (Venezuela) originated more than 60 percent of all members' exports. More recently, Michaely (1994) demonstrated the lack of similarities between member countries major imports and exports also played a role in the failure of these agreements. How important are relative size differences in East Asian regional trade shares, or in the share of regional GDP originating in each country?

Table 3.1 shows the value and share of regional exports that originated in each East Asian country in 1985,1995 or 2001 , along with its current share of regional gross domestic product. As indicated, the five largest regional exporters now account for 80 percent of intra-trade, although China is the dominant supplier originating almost one-third of this exchange. At the other end of the spectrum, the five smallest regional exporters, namely, Brunei, Cambodia, Lao PDR, Mongolia and Vietnam have a combined trade share under 2 percent. In addition, the data suggest the relative size differences have been increasing. Over $1985-2001$ the share of the current five largest countries in regional trade rose by almost 10 percentage points, due largely to China and the Republic of Korea.

If size is measured by the origins of regional gross domestic product a somewhat different picture emerges. China alone accounts for 43 percent of regional GDP (it originates about 30 percent of intraregional trade) as opposed to about one-tenth of a percent for Cambodia, Laos, and Mongolia. Aside from China the greatest disparities in the "size" measures occur for Singapore and Malaysia where their regional trade shares are roughly three times high than their GDP shares. 
Finally, there is the problem of how to properly account for the proper size of China in any East Asian regional arrangement. As indicated in the memo item, greater China, that is, China plus Hong Kong plus Taiwan would originate about one-half of all regional exports, and absorb about 55 percent of regional imports (import data not shown in Table 3.1). Currently, China and Hong Kong generate about 50 percent of regional GDP and this share would rise to about 65 percent if Taiwan (China) were included. For comparison, at the time of the original EU formation Germany, the largest country, produced about 30 percent of the member's gross domestic product. Greater China, like Brazil in MERCOSUR, clearly is of major importance in East Asian regional intra-trade.

Table 3. 1 The Share of Intra-Regional Trade Accounted for by Individual East Asian Exporters: 1985, 1995 and 2001

\begin{tabular}{|c|c|c|c|c|c|c|c|}
\hline \multirow[b]{2}{*}{ Exporter } & \multicolumn{3}{|c|}{$\begin{array}{l}\text { Intra-Regional Export Value* } \\
\text { (\$million) }\end{array}$} & \multicolumn{3}{|c|}{$\begin{array}{l}\text { Share of Intra-Regional } \\
\text { Exports }(\%)^{*}\end{array}$} & \multirow{2}{*}{$\begin{array}{c}2000 \\
\text { Share of } \\
\text { Regional } \\
\text { GDP }\end{array}$} \\
\hline & 1985 & 1995 & 2001 & 1985 & 1995 & 2001 & \\
\hline Brunei & 922 & 951 & 1,192 & 2.1 & 0.3 & 0.3 & 0.4 \\
\hline Cambodia & 3 & 276 & 182 & -- & 0.1 & -- & 0.1 \\
\hline China & 10,867 & 90,799 & 127,796 & 24.7 & 28.9 & 30.6 & 43.1 \\
\hline Hong Kong & 6,637 & 20,016 & 20,981 & 15.1 & 6.4 & 5.0 & 7.5 \\
\hline Indonesia & 1,953 & 12,008 & 17,155 & 4.4 & 3.8 & 4.1 & $\begin{array}{c}4.2 \\
144\end{array}$ \\
\hline Korea & 2,559 & 40,346 & 55,748 & 5.8 & 12.8 & 13.3 & $\begin{array}{l}14.4 \\
0.1\end{array}$ \\
\hline Lao PDR & 17 & 190 & 220 & -- & 0.1 & 0.1 & 3.3 \\
\hline Malaysia & 6,844 & 37,642 & 46,759 & 15.5 & 12.0 & 11.2 & 0.1 \\
\hline Mongolia & 4 & 111 & 242 & 0.0 & 0.0 & 0.1 & 2.9 \\
\hline Philippines & 1,071 & 4,645 & 14,736 & 2.4 & 1.5 & 3.5 & 3.8 \\
\hline Singapore & 6,032 & 38,979 & 41,806 & 13.7 & 12.4 & 10.0 & 13.9 \\
\hline Taiwan, China & 4,994 & 49,069 & 62,477 & 11.3 & 15.6 & 14.9 & 5.0 \\
\hline Thailand & 1,982 & 17,548 & 24,359 & 4.5 & 5.6 & 5.8 & 1.2 \\
\hline Vietnam & 182 & 1,916 & 4,354 & 0.4 & 0.6 & 1.0 & 100.0 \\
\hline All Above Countries & 44,067 & 314,496 & 418,007 & 100.0 & 100.0 & 100.0 & \\
\hline MEMO ITEM & & & & & & & $\begin{array}{l}50.6 \\
64.5\end{array}$ \\
\hline China and Hong Kong & 17,504 & 110,815 & 148,777 & 39.8 & 35.3 & 35.6 & \\
\hline China, Hong Kong and Taiwan & 22,498 & 159,884 & 211,254 & 51.1 & 50.9 & 50.5 & 21.0 \\
\hline ASEAN & 19,006 & 114,155 & $150 ; 763$ & 43.1 & 36.3 & 36.1 & \\
\hline
\end{tabular}

* Brunei, Cambodia, China, Republic of Korea, Hong Kong, Indonesia, Lao PDR, Malaysia, Mongolia, Philippines, Singapore, Taiwan (China), Thailand, Vietnam

Source: IMF Direction of Trade clata. 


\section{Trade Trends 4 \\ Regional Implications of China's Emergence}

\section{Key Point}

Over 1995-2001, East Asia's exports to China grew at an average annual rate of 11.5 percent, which was far above the corresponding 3.8 percentage growth rate for world trade. China's internal contra-cyclical policies, and its maintenance of a stable exchange rate during this period, are generally viewed as important factors helping to contain the effects of the Asian financial crisis. Furthermore, the profile of China's imports and exports is changing in directions that facilitate the international segmentation of production processes. As a result, the interdependence of China and the East Asian countries has been rapidly increasing.

Since the mid-1980s China has become an increasingly important factor in both world and East Asian regional markets. In 1985, China accounted for about 1.6 percent of global exports as opposed to about 6.5 percent in 2001 . Viewed somewhat differently, in 1985 China's global exports were about 40 percent lower than the combined exports of all Sub-Saharan African countries. In 2001, just 16 years later, China's exports were more than four times higher. China's emergence has had a major positive impact on the trade of other East Asian countries. For example, over 1995-2001 East Asia's exports to China grew at an average annual rate of 11.5 percent, which was far above the corresponding 3.8 percentage growth rate for world trade. China's internal contra-cyclical policies, and its maintenance of a stable exchange rate during this period, are generally viewed as important factors helping to contain the effects of the Asian financial crisis. At present, China's regional trade is more that double that of Taiwan (China) which is the second largest East Asian exporter (see Table 3.1).

A point that has received less attention, however, is that major changes also occurred in the structure of China's trade with East Asia that also have important implications for the region. The share of machinery and transport equipment products in China's regional exports rose almost seven fold (to 38 percent) since 1985, while sizeable declines occurred in the trade shares for foodstuffs, agricultural materials, and mineral fuels. There is evidence that the magnitude of ties between China and the regional countries are rapidly growing in relative importance. For example, analyses based on the use of so called "trade intensity" indices show that trade between China and individual East Asian countries is considerably greater than what should be expected based their proximity and relative size in world trade (see $\underline{\text { Trade }}$ Trends 8 that follows).

As an illustration of the changing nature of China's trade with East Asia, Table 4.1 lists China's 30 largest four-digit imports from other East Asian countries in 2001 and also shows their value and share in 1987 and $1995 .^{5} \quad$ The three largest products, which account for approximately 15 percent of total regional imports, consist of parts and components for further assembly. Often these components are produced in relatively high wage countries, like Singapore or the Republic of Korea, who then capitalize on China's relatively low wage costs for product assembly - which is often a labor intensive process. The growth of some component product imports has been remarkable. For example, from 1995 to 2001 imports of office machinery parts grew approximately six fold, while imports of electronic microcircuits are now nine times their corresponding level in 1995. As a result of this internationalization of product processes the interdependence of China and other East Asian countries has been greatly strengthened.

5 Although data on China's total imports and exports are available from the IMF Direction of Trade Statistics, only UN COMTRADE records provide a detailed breakdown of the products traded in terms of the Standard International Trade Classification system China did not report trade statistics to the UN prior to 1987 so this is the first year for which product line trade data are available for analysis. 
Table 4.1 The 30 Largest Products in China's Imports from East Asia; 1987, 1995 and 2001

\begin{tabular}{|c|c|c|c|c|c|c|c|}
\hline \multirow[b]{2}{*}{ SITC } & \multirow[b]{2}{*}{ Product } & \multicolumn{3}{|c|}{ Export Value $(\$ 000)$} & \multicolumn{3}{|c|}{ Export Share (\%) } \\
\hline & & 1987 & 1995 & 2001 & 1987 & 1995 & 2001 \\
\hline 7599 & Parts of office machines & 50,722 & 490,818 & $2,869,804$ & 0.94 & 1.88 & 6.45 \\
\hline 7764 & Electronic microcircuits & 10,199 & 228,983 & $2,021,807$ & 0.19 & 0.88 & 4.54 \\
\hline 7649 & Parts of telecom equipment & 473,013 & $1,235,248$ & $1,570,519$ & 8.75 & 4.74 & 3.53 \\
\hline 5138 & Poly-carbonic acids & 890 & 230,246 & $1,084,298$ & 0.02 & 0.88 & 2.44 \\
\hline 5831 & Polyethylene & 42,910 & 548,252 & 997,861 & 0.79 & 2.10 & 2.24 \\
\hline 5833 & Polystyrene & 68,824 & 535,690 & 806,538 & 1.27 & 2.06 & 1.81 \\
\hline 7284 & Special industry machines & 73,015 & 460,893 & 716,848 & 1.35 & 1.77 & 1.61 \\
\hline 3330 & Petroleum oils & 0 & 803,865 & 628,421 & 0.00 & 3.09 & 1.41 \\
\hline 5112 & Cyclic hydrocarbons & 6,252 & 408,371 & 626,479 & 0.12 & 1.57 & 1.41 \\
\hline 7768 & Piezo-electric crystals & 7,925 & 70,075 & 622,133 & 0.15 & 0.27 & 1.40 \\
\hline 7762 & Electrical valves and tubes & 177 & 13,024 & 581,159 & 0.00 & 0.05 & 1.31 \\
\hline 6552 & Knitted fabrics & 100,251 & 460,805 & 569,087 & 1.85 & 1.77 & 1.28 \\
\hline 7761 & Television picture tubes & 2,857 & 146,215 & 549,693 & 0.05 & 0.56 & 1.24 \\
\hline 5834 & Polyvinyl chloride & 56,122 & 212,458 & 548,773 & 1.04 & 0.82 & 1.23 \\
\hline 6746 & Iron sheets and plates & 4 & 180,986 & 540,908 & 0.00 & 0.69 & 1.22 \\
\hline 8451 & Jerseys and pullovers & 56,820 & 191,990 & 530,948 & 1.05 & 0.74 & 1.19 \\
\hline 5121 & Acyclic alcohols & 20,104 & 90,731 & 517,723 & 0.37 & 0.35 & 1.16 \\
\hline 6573 & Coated textile fabrics & 29,992 & 247,752 & 450,836 & 0.55 & 0.95 & 1.01 \\
\hline 6114 & Bovine leather & 27,685 & 465,378 & 443,100 & 0.51 & 1.79 & 1.00 \\
\hline 5832 & Polypropylene & 33,466 & 405,059 & 440,034 & 0.62 & 1.56 & 0.99 \\
\hline 3413 & Petroleum gases & 136 & 158,981 & 430,925 & 0.00 & 0.61 & 0.97 \\
\hline 7524 & Digital storage units & 17 & 41,937 & 422,290 & 0.00 & 0.16 & 0.95 \\
\hline 7788 & Other electrical machinery & 25,693 & 150,333 & 420,781 & 0.48 & 0.58 & 0.95 \\
\hline 2320 & Natural rubber & 378,006 & 369,856 & 415,131 & 6.99 & 1.42 & 0.93 \\
\hline 6727 & Iron or steel coils & 0 & 116,099 & 410,476 & 0.00 & 0.45 & 0.92 \\
\hline 4242 & Palm oil & 5,963 & 687,280 & 408,704 & 0.11 & 2.64 & 0.92 \\
\hline 8471 & Clothing accessories & 50,182 & 109,219 & 405,531 & 0.93 & 0.42 & 0.91 \\
\hline 6412 & Printing paper & 295 & 268,817 & 394,777 & 0.01 & 1.03 & 0.89 \\
\hline 6522 & Cotton fabrics & 227,577 & 392,338 & 380,991 & 4.21 & 1.51 & 0.86 \\
\hline 6531 & Synthetic fabrics & 30,499 & 377,074 & 380,585 & 0.56 & 1.45 & 0.86 \\
\hline 0 to 9 & $\begin{array}{l}\text { All above products } \\
\text { All goods }\end{array}$ & $\begin{array}{l}1,779,594 \\
5,406,025\end{array}$ & $\begin{array}{l}10,098,773 \\
26,046,467\end{array}$ & $\begin{array}{l}21,187,159 \\
44,488,304\end{array}$ & $\begin{array}{c}32.92 \\
100.00\end{array}$ & $\begin{array}{c}38.77 \\
100.00\end{array}$ & $\begin{array}{l}47.62 \\
100.00\end{array}$ \\
\hline
\end{tabular}

Source: UN COMTRADE statistics

While parts and components also appear in the list of China's major regional exports (often these products are manufactured in association with Hong Kong - see Trade Trends 18), Table 4.2 suggest East Asian countries often draw on China as a supplier of goods normally produced using labor intensive manufacturing processes. The textile, clothing and footwear products listed in the table account for about 14 percent of China's regional exports. This share increases to over 20 percent if other items, like toys and footwear, which are normally produced by labor intensive processes, are included. Although the exact dimensions of this activity cannot be determined, World Bank (1994) consultations with Chinese government officials using thread, fabrics, or other unassembled or partly assembled materials produced abroad. China actively encourage these types of operations through the use of duty drawback schemes and other trade incentives on intermediate good imports that will be further processed and then exported. As such, both China's imports and exports reflect rapidly growing interdependence with other Asian countries due to the international "splitting up" of production processes. 
Table 4.2 The 30 Largest Products in China's Exports to East Asia; 1987, 1995 and 2001

\begin{tabular}{|c|c|c|c|c|c|c|c|}
\hline \multirow[b]{2}{*}{ SITC } & \multirow[b]{2}{*}{ Product } & \multicolumn{3}{|c|}{ Export Value $(\$ 000)$} & \multicolumn{3}{|c|}{ Export Share (\%) } \\
\hline & & 1987 & 1995 & 2001 & 1987 & 1995 & 2001 \\
\hline 8942 & Children s toys. & 747,991 & $4,997,380$ & $5,804,360$ & 4.16 & 5.54 & 4.67 \\
\hline 7599 & Parts of office machinery & 44,387 & $1,539,151$ & $5,613,303$ & 0.25 & 1.71 & 4.52 \\
\hline 8510 & Footwear & 265,788 & $6,080,400$ & $4,832,699$ & 1.48 & 6.74 & 3.89 \\
\hline 7649 & Parts of telecom equipment & 159,007 & $1,722,096$ & $4,454,386$ & 0.88 & 1.91 & 3.58 \\
\hline 8451 & Jerseys and pullovers & 464,827 & $1,861,786$ & $3,610,732$ & 2.59 & 2.06 & 2.91 \\
\hline 8310 & Travel goods & 563,662 & $3,140,776$ & $3,130,025$ & 3.14 & 3.48 & 2.52 \\
\hline 7712 & Electric power machinery & 30,873 & 942,769 & $2,517,265$ & 0.17 & 1.04 & 2.03 \\
\hline 7643 & Radiotelephonic equipment & 3,949 & 674,338 & $2,427,842$ & 0.02 & 0.75 & 1.95 \\
\hline 8459 & Knit outer garments & 367,769 & $1,031,914$ & $2,021,568$ & 2.05 & 1.14 & 1.63 \\
\hline 7638 & Sound recorders & 42,345 & $1,022,828$ & $1,957,036$ & 0.24 & 1.13 & 1.57 \\
\hline 8439 & Other outer garments & 246,762 & $1,272,787$ & $1,846,140$ & 1.37 & 1.41 & 1.49 \\
\hline 8462 & Under garments & 198,525 & $1,499,694$ & $1,836,566$ & 1.10 & 1.66 & 1.48 \\
\hline 8939 & Miscellaneous articles & 107,399 & $1,170,145$ & $1,798,534$ & 0.60 & 1.30 & 1.45 \\
\hline 7525 & Peripheral control units & 5,366 & 215,958 & $1,749,821$ & 0.03 & 0.24 & 1.41 \\
\hline 7788 & Other electrical machinery & 51,935 & 617,227 & $1,674,432$ & 0.29 & 0.68 & 1.35 \\
\hline 7641 & Telephonic line & 60,177 & 838,522 & $1,665,002$ & 0.33 & 0.93 & 1.34 \\
\hline 7721 & Switches and relays & 39,395 & 689,593 & $1,565,098$ & 0.22 & 0.76 & 1.26 \\
\hline 7764 & Electronic microcircuits & 1,918 & 222,354 & $1,540,239$ & 0.01 & 0.25 & 1.24 \\
\hline 7524 & Digital storage units & 0 & 439,188 & $1,520,902$ & 0.00 & 0.49 & 1.22 \\
\hline 6552 & Knitted fabrics & 136,737 & 705,440 & $1,455,088$ & 0.76 & 0.78 & 1.17 \\
\hline 6522 & Cotton fabrics & 515,919 & $1,763,450$ & $1,420,636$ & 2.87 & 1.95 & 1.14 \\
\hline 7162 & Electric motors & 29,141 & 924,022 & $1,415,277$ & 0.16 & 1.02 & 1.14 \\
\hline 3222 & Other coal & 84,722 & 554,337 & $1,389,743$ & 0.47 & 0.61 & 1.12 \\
\hline 7758 & Electro-thermal appliances. & 109,531 & $1,088,780$ & $1,297,473$ & 0.61 & 1.21 & 1.04 \\
\hline 7731 & Insulated electrical wire & 31,174 & 597,212 & $1,292,963$ & 0.17 & 0.66 & 1.04 \\
\hline 8851 & Watches and movements & 221,653 & $1,462,017$ & $1,258,668$ & 1.23 & 1.62 & 1.01 \\
\hline 7722 & Printed circuits and parts & 11,073 & 233,719 & $1,228,034$ & 0.06 & 0.26 & 0.99 \\
\hline 8811 & Photographic cameras & 33,758 & 622,677 & $1,156,399$ & 0.19 & 0.69 & 0.93 \\
\hline 7757 & Domestic appliances & 84,288 & 976,719 & $1,103,904$ & 0.47 & 1.08 & 0.89 \\
\hline \multirow[t]{2}{*}{8423} & Trousers & 235,975 & 858,065 & $1,071,445$ & 1.31 & 0.95 & 0.86 \\
\hline & All above products & $4,896,049$ & $39,765,344$ & $65,655,581$ & 27.24 & 44.06 & 52.83 \\
\hline 0 to 9 & All goods & $17,975,100$ & $90,243,269$ & $124,282,677$ & 100.00 & 100.00 & 100.00 \\
\hline
\end{tabular}

Source: United Nations COMTRADE records. Prior to 1987 China did not report trade statistics to the United Nations. 
Trade Trends 5

East Asian Regional Intra-Trade

(Who is Dependent - Who is Not?)

\section{$\underline{\text { Key Point }}$}

Overall, East Asian average intra-trade shares for both exports and imports increased significantly during 1985-2001, thus, indicating increased dependency on regional trade. Seven of the 14 East Asian countries now draw on regional suppliers for 50 percent, or more, of their total imports, while only Lao PDR directs more than one-half its exports to the region. Increased dependency is reflected in all countries' regional import and export shares, although China's increasing reliance on non-regional markets for its exports constitutes an important exception. Available evidence does not indicate smaller countries are more dependent on regional markets for trade.

Several published studies show larger countries often are able to export a broader range of products that, in turn, helps them extend the geographic directions of their trade. ${ }^{6}$ If they have a larger trade base larger, or wealthier, countries may be better able to develop required logistical infrastructure to maintain commercial relations with a greater number of trading partners. If this is the case it might be presumed that the smaller East Asian countries may be more dependent on relatively near regional markets. As such, an important question is what variation exists in individual country's dependency on regional markets, and what factors account for these differences.

The top one-half of Table 5.1 provides information on individual East Asian country's trade dependency by reporting global export values and the share of this exchange destined for regional markets. The lower one-half of the table provides corresponding information on imports. In each case, the share of the country in regional GDP (a measure of relative size) is shown for an initial assessment of the relationship between size and regional trade dependency. Two points are evident from these statistics,

- East Asian average shares for both regional exports and imports increased by 11 and 15 percentage points, respectively, over 1985-2001, thus indicating increased dependency on regional trade. Increased dependency is reflected in all 14 countries regional import shares, although the relative importance of non-regional markets increased for China's exports. Some of the shares, however, appear to be quite volatile. For example, from 1995 to 2001 the share of Cambodia's exports destined for regional markets fell by 60 percentage points to about 10 percent. Over the same, relatively short, period a 20 percentage point increase occurred in Mongolia's regional export share.

- Sizeable differences exist in the individual East Asian country's trade dependency ratios in the case of both imports and exports. However, the relative variation is considerably larger for imports, as reflected in a coefficient of variation of $\mathbf{4 2 . 9}$ percent, as opposed to 30.8 percent for exports. Laos PDR and Cambodia currently source about 90 percent of their total imports from regional countries, while 60 percent of the formers exports go to other East Asian countries. However, there is no indication that these variations are associated with country size. Statistical tests indicate the dependency ratios are not

\footnotetext{
${ }^{6}$ Khalaf (1974) examined the relationship between country size and trade concentration and determined that small countries' exports were generally less diversified. Tuong and Yeats (1977) extended these findings and showed smaller countries often were able to maintain relatively fewer trade contacts. In the 1960 s and 1970s, these investigations were motivated by the proliferation of new small states, particularly in Africa, and the feeling that there may be some critical size below which countries were not economically viable. More recently, $\mathrm{Ng}$ and Yeats (2002) determined that a relatively strong relationship still existed between the size of Sub-Saharan African countries and the diversity of their exports.
} 
significantly correlated with the relative size of each country's global exports or imports, or the share of the country in regional gross domestic product. In spite of previous evidence that size can influence the direction of a country's trade, it does not appear to be an important factor in East Asia.

Table 5. 1 The Share of Intra-Regional Trade in East Asian Imports and Exports; 1985, 1995 and 2001

\begin{tabular}{|l|c|c|c|c|c|c|}
\hline & \multicolumn{3}{|c|}{ Global Trade Value } & \multicolumn{2}{c|}{ Share of Intra-Regional Trade in } \\
\cline { 2 - 7 } East Asian Trader* & 1985 & 1995 & 2001 & 1985 & 1995 & 2001 \\
\hline EXPORTS & & & & & & \\
Brunei Darussalam (0.4) & 2,864 & 2,573 & 3,632 & 32.2 & 37.0 & 32.8 \\
Cambodia (0.1) & 7 & 393 & 1,719 & 52.2 & 70.1 & 10.6 \\
China (43.1) & 30,928 & 232,487 & 414,884 & 35.1 & 39.1 & 30.8 \\
Hong Kong, China (7.5) & 24,108 & 56,163 & 59,649 & 27.5 & 35.6 & 35.2 \\
Indonesia (4.2) & 19,661 & 47,987 & 63,132 & 9.9 & 25.0 & 27.2 \\
Korea (14.4) & 25,240 & 118,360 & 163,645 & 10.1 & 34.1 & 34.1 \\
Lao P. D. Rep. (0.1) & 22 & 345 & 364 & 75.2 & 55.1 & 60.3 \\
Malaysia (3.3) & 17,982 & 86,557 & 111,422 & 38.1 & 43.5 & 42.0 \\
Mongolia (0.1) & 81 & 380 & 489 & 4.7 & 29.2 & 49.6 \\
Philippines (2.9) & 6,110 & 19,802 & 42,870 & 17.5 & 23.5 & 34.4 \\
Singapore (3.8) & 17,208 & 88,932 & 93,178 & 35.1 & 43.8 & 44.9 \\
Taiwan, China (13.9) & 33,797 & 123,903 & 151,942 & 14.8 & 39.6 & 41.1 \\
Thailand (5.0) & 7,771 & 54,975 & 72,624 & 25.5 & 31.9 & 33.5 \\
Vietnam (1.2) & 377 & 6,189 & 14,851 & 48.4 & 31.0 & 29.3 \\
All Above Exporters & 186,156 & 839,044 & $1,194,400$ & 23.7 & 37.5 & 35.0 \\
& & & & & & \\
IMPORTS & & & & & & \\
Brunei Darussalam (0.4) & 663 & 3,090 & 1,202 & 55.2 & 62.3 & 70.8 \\
Cambodia (0.1) & 28 & 1,430 & 1,962 & 68.9 & 84.1 & 89.4 \\
China (43.1) & 38,189 & 145,981 & 222,108 & 23.0 & 52.1 & 49.8 \\
Hong Kong, China (7.5) & 29,469 & 169,508 & 173,798 & 46.8 & 54.6 & 60.0 \\
Indonesia (4.2) & 7,778 & 36,079 & 31,526 & 13.8 & 25.8 & 37.3 \\
Korea (14.4) & 21,380 & 119,208 & 131,076 & 13.4 & 18.7 & 25.8 \\
Lao P. D. Rep. (0.1) & 53 & 593 & 651 & 64.5 & 81.2 & 90.7 \\
Malaysia (3.3) & 11,742 & 76,021 & 73,251 & 44.4 & 45.2 & 51.6 \\
Mongolia (0.1) & 87 & 489 & 596 & 7.5 & 24.7 & 39.1 \\
Philippines (2.9) & 5,743 & 29,236 & 39,596 & 34.1 & 33.6 & 37.1 \\
Singapore (3.8) & 25,560 & 114,164 & 111,074 & 39.2 & 42.2 & 43.5 \\
Taiwan, China (13.9) & 18,169 & 94,962 & 100,776 & 12.7 & 22.3 & 31.4 \\
Thailand (5.0) & 7,972 & 65,690 & 55,671 & 33.4 & 31.6 & 36.2 \\
Vietnam (1.2) & 576 & 9,942 & 15,028 & 33.4 & 68.1 & 64.9 \\
All Above Importers & 167,409 & 866,393 & 958,314 & 29.4 & 39.8 & 44.5 \\
\hline
\end{tabular}

* Statistics in parentheses show the 2000 share of each economy in regional gross domestic product. This has been included as a measure of market size to help determine if larger economies are generally less dependent on regional trade.

Source: IMF Direction of Trade Data 
If size is not a factor, what explains the variation in regional trade shares observed in Table 5.1. Almost certainly considerations relating to comparative advantage have an influence. Some countries comparative advantage may, more strongly, direct trade toward non-regional market to better exploit differences in natural resource endowments or differences in worker wage costs or productivity. Government imposed trade barriers may also be important. For example, Safadi and Yeats (1993) determined that Asian trade barriers often escalate sharply with commodity processing. This appeared to be an important barrier to increased regional trade in processed natural resource based products. In addition, there is a growing appreciation of the importance of the influence of international transport costs on the direction of trade. The World Bank (2003), for example, cites evidence that on some liner routes transport and insurance costs may double the fob cost of products exported from Vietnam, Laos and Cambodia.

\section{Trade Trends 6}

\section{Changing Geographic Patterns of Regional Trade Dependency}

\section{$\underline{\text { Key Point }}$}

The relative importance of China as a destination for regional exports significantly increased since the mid-1980s, and this trend appears to have sharply accelerated since 1995. In part, China's maintenance of a stable exchange rate, in the face of major devaluations in other East Asian currencies, appears to have contributed to its recent increased importance as a regional market.

The conclusion that East Asian countries became increasingly interdependent in trade raises questions concerning the factors responsible. Was a diversification of products exported a factor promoting regional trade, or did increased opportunities for intra-industry trade play a role? Do the changes reflect an increasing complementarity of regional exports and imports, were the gains due to increased competitiveness of East Asian exporters, or were growing opportunities for international production sharing a factor. While these points will be addressed in sections that follow, the focus here is on the intra-regional geographic pattern of this increased dependency. Specifically, was the overall increase in the importance of trade clue to a relatively few countries, or was it generally broad based across the region?

For answers, a 1985, 1995 and 2001 bilateral regional matrix of export shares for each East Asian country's exports was first constructed (see Appendix Table A6.1). Next, differences in the 1985-2001 and 1995-2001 shares were calculated, and the largest positive and negative changes identified. The intention here was to try and determine how the direction of regional trade was changing, both in the longer term and over the period of the East Asian financial crisis.

Information on the longer-term 1985-2001 East Asian trade share changes is summarized in Table 6.1. As an example, the table show: China's largest positive 1985 to 2001 export share increase (a gain of over 10 percentage points) occurred in trade with Korea, while the second largest gain (4.6 points) was in trade with Taiwan (China). In contrast, the share of China's regional exports destined for Singapore fell by 15 percentage points. The largest of all bilateral regional trade share gains was recorded for Mongolia's exports to China (up 46 percentage points), while the largest decline (down almost 54 percentage points) was for Laos PDR exports to China.. Similarly, Table 6.2 provides similar statistics for the recent 1995 2001 period.

The statistics in Table 6.1 confirm the longer-term increase in China's relative importance as a destination for regional exports during 1985-2001, but the data in Table 6.2 strongly suggest China's' this swing toward China accelerated over 1995-2001. For example, 11 of the 13 countries listed in Table 6.2 record their largest, or second largest regional trade share increase for exports to China. In this six year 
Table 6.1 Major Changes in East Asian Regional Trade Dependency: 1985-2001.

\begin{tabular}{|c|c|c|c|c|c|c|}
\hline \multirow[b]{3}{*}{ Exporter } & \multicolumn{4}{|c|}{ Export Markets Increasing In Relative Importance } & \multirow{2}{*}{\multicolumn{2}{|c|}{$\begin{array}{l}\text { Largest Declining } \\
\text { Market Share }\end{array}$}} \\
\hline & \multicolumn{2}{|c|}{$\begin{array}{l}\text { Largest Market Share } \\
\text { Increase }\end{array}$} & \multicolumn{2}{|c|}{$\begin{array}{l}\text { Second Largest Market Share } \\
\text { Increase }\end{array}$} & & \\
\hline & Importer & $\begin{array}{l}\text { \% Point } \\
\text { Change }\end{array}$ & Importer & $\begin{array}{l}\text { \% Point } \\
\text { Change }\end{array}$ & Importer & $\begin{array}{l}\text { \% Point } \\
\text { Change }\end{array}$ \\
\hline Brunei & Korea & 13.7 & China & 12.4 & Singapore & -11.4 \\
\hline Cambodia & Thailand & 6.8 & Hong Kong & 6.5 & Vietnam & -23.1 \\
\hline China & Korea & 10.4 & Taiwan, China & 4.6 & Singapore & -15.3 \\
\hline Hong Kong & Malaysia & 5.9 & Singapore & 5.9 & China & -26.9 \\
\hline Indonesia & Malaysia & 6.0 & China & 5.8 & Korea & -8.1 \\
\hline Korea & China & 42.0 & Taiwan, China & 4.7 & Hong Kong, China & -25.2 \\
\hline Lao PDR & Thailand & 33.5 & Vietnam & 31.3 & China & -53.8 \\
\hline Malaysia & China & 10.4 & Hong Kong, China & 8.3 & Singapore & -11.6 \\
\hline Mongolia & China & 46.2 & Korea & 1.0 & Vietnam & -47.4 \\
\hline Philippines & Taiwan, China & 12.4 & China & 4.2 & Malaysia & -9.0 \\
\hline Singapore & China & 8.3 & Vietnam & 5.1 & Malaysia & -10.1 \\
\hline Taiwan, China & China & 43.8 & Vietnam & 3.0 & Hong Kong, China & -31.5 \\
\hline Thailand & China & 6.0 & Indonesia & 3.8 & Malaysia & -10.0 \\
\hline Vietnam & China & 23.2 & Taiwan, China & 9.6 & Hong Kong, China & -48.7 \\
\hline
\end{tabular}

Source: IMF Direction of Trade Data.

period, the regional share of Brunei, Cambodia, Korean, Taiwan (China), and Thailand's exports to China rose by 10 percentage points, or more, with the increase for Cambodia and Korea exceeding 16 points. However, in cases these recent changes were clearly part of a longer-term trend. For example, Table 6.1 shows that over 1985-2001 the share of Korea's exports destined for China rose by 42 percentage points. Roughly two-fifths of this increase occurred within the 1995-2001 sub-interval.

Apart from the longer-term trends, what factors account for the recent acceleration in the importance of China in regional trade. In part, one important factor was China's economic policies during the period of the Asian financial crisis. China is widely seen as having contributed to stability in 1997-98 by maintaining a fixed exchange rate in the face of major devaluations of other East Asian currencies. The combination of a strong currency and strong growth in China, set against weakening currencies in other East Asian countries, clearly contributed to the re-orientation of trade regional toward Chinese markets.

Table 6.2 Major Changes in East Asian Regional Trade Dependency: 1995-2001.

\begin{tabular}{|c|c|c|c|c|c|c|}
\hline \multirow[b]{3}{*}{ Exporter } & \multicolumn{4}{|c|}{ Export Markets Increasing In Relative Importance } & \multirow{2}{*}{\multicolumn{2}{|c|}{$\begin{array}{l}\text { Largest Declining } \\
\text { Market Share }\end{array}$}} \\
\hline & \multicolumn{2}{|c|}{$\begin{array}{l}\text { Largest Market Share } \\
\text { Increase }\end{array}$} & \multicolumn{2}{|c|}{$\begin{array}{l}\text { Second Largest Market Share } \\
\text { Increase }\end{array}$} & & \\
\hline & Importer & $\begin{array}{l}\text { \% Point } \\
\text { Change }\end{array}$ & Importer & $\begin{array}{l}\text { \% Point } \\
\text { Change }\end{array}$ & Importer & $\begin{array}{l}\text { \% Point } \\
\text { Change }\end{array}$ \\
\hline Brunei & China & 12.4 & Thailand & 2.1 & Singapore & -8.3 \\
\hline Cambodia & China & 17.0 & Singapore & 14.7 & Thailand & -51.5 \\
\hline China & Korea & 2.2 & Taiwan, China & 1.2 & Hong Kong, China & -8.3 \\
\hline Hong Kong & Indonesia & 3.0 & Hong Kong, China & 1.7 & Singapore & -7.2 \\
\hline Indonesia & China & 5.6 & Malaysia & 3.0 & Hong Kong, China & -4.9 \\
\hline Korea & China & 16.5 & Taiwan, China & 1.3 & Hong Kong, China & -7.1 \\
\hline Lao PDR & Vietnam & 8.8 & Thailand & 3.9 & Taiwan, China & -7.6 \\
\hline Malaysia & China & 7.8 & Korea & 2.1 & Singapore & -8.1 \\
\hline Mongolia & China & 8.1 & Thailand & 0.1 & Korea & -7.7 \\
\hline Philippines & Taiwan, China & 8.2 & China & 7.3 & Singapore & -5.2 \\
\hline Singapore & China & 3.6 & Indonesia & 2.9 & Thailand & -3.9 \\
\hline Taiwan, China & China & 13.7 & Indonesia & 2.6 & Hong Kong, China & -11.9 \\
\hline Thailand & China & 10.1 & Indonesia & 2.0 & Singapore & -15.4 \\
\hline Vietnam & China & 5.9 & Thailand & 5.3 & Taiwan, China & -4.5 \\
\hline
\end{tabular}


Appendix Table A6.1 The Origins and Destinations of East Asian Intra-Trade in 1985, 1995 and 2001

\begin{tabular}{|c|c|c|c|c|c|c|c|c|c|c|c|c|c|}
\hline \multirow[b]{2}{*}{$\begin{array}{l}\text { Origin of } \\
\text { Regional Exports }\end{array}$} & \multirow[b]{2}{*}{ Year } & \multirow{2}{*}{$\begin{array}{l}\text { Regional } \\
\text { Exports } \\
\text { (\$ Mill.) } \\
\end{array}$} & \multicolumn{11}{|c|}{ Share of Regional Exports Destined For (\%) } \\
\hline & & & China & $\begin{array}{l}\text { Hong } \\
\text { Kong }\end{array}$ & Indonesia & $\begin{array}{c}\text { Rep. of } \\
\text { Korea }\end{array}$ & Malaysia & Philippines & Singapore & $\begin{array}{l}\text { Taiwan } \\
\text { (China) } \\
\end{array}$ & Thailand & Vietnam & Others* \\
\hline \multirow[t]{3}{*}{ Brunei } & $\overline{1985}$ & 922 & 0.0 & 0.1 & 0.1 & 24.2 & 0.1 & 1.6 & 26.6 & 11.4 & 35.9 & 0.0 & . \\
\hline & 1995 & 951 & 0.0 & 0.1 & 0.0 & 39.5 & 0.4 & 0.8 & 23.5 & 5.3 & 30.4 & 0.0 & . \\
\hline & 2001 & 1,192 & 12.4 & 0.1 & 1.4 & 37.9 & 0.4 & 0.0 & 15.2 & 0.0 & 32.5 & 0.0 & . \\
\hline \multirow[t]{3}{*}{ Cambodia } & 1985 & 3 & 17.5 & 0.0 & 0.0 & & 10.8 & 0.0 & 33.8 & 0.0 & 0.0 & 37.9 & \\
\hline & 1995 & 276 & 2.1 & 4.5 & 1.6 & 0.0 & 5.3 & 0.0 & 15.3 & 3.5 & 58.3 & 8.5 & 1.0 \\
\hline & 2001 & 182 & 19.1 & 6.5 & 0.4 & 3.9 & 10.4 & 1.8 & 30.0 & 5.8 & 6.8 & 14.8 & 0.6 \\
\hline \multirow[t]{3}{*}{ China } & 1985 & 10,867 & -- & 69.6 & 2.3 & 0.0 & 2.3 & 2.7 & 20.9 & $0^{\circ}$ & 2.0 & 0.0 & 0.1 \\
\hline & 1995 & 90,799 & -- & 76.8 & 1.6 & 8.2 & 2.9 & 0.7 & 4.5 & 3.4 & 2.3 & 0.4 & 0.3 \\
\hline & 2001 & 127,796 & -- & 68.5 & 2.4 & 10.4 & 3.0 & 0.7 & 5.6 & 4.6 & 2.9 & 1.6 & 0.2 \\
\hline \multirow{3}{*}{ Hong Kong } & 1985 & 6,637 & 71.8 & -- & 0.8 & 6.7 & 3.1 & 3.2 & 7.4 & 4.8 & 1.6 & 0.4 & 0.1 \\
\hline & 1995 & 20,016 & 43.0 & -- & 1.4 & 4.2 & 8.4 & 6.9 & 20.5 & 9.2 & 3.7 & 2.1 & 0.7 \\
\hline & 2001 & 20,981 & 44.9 & - & 4.4 & 5.9 & 9.0 & 6.0 & 13.3 & 8.8 & 3.9 & 2.8 & 1.0 \\
\hline \multirow[t]{3}{*}{ Indonesia } & 1985 & 1,953 & 16.9 & 7.7 & - & 34.2 & 7.1 & 9.7 & . & 21.2 & 3.1 & 0.0 & \\
\hline & 1995 & 12,008 & 17.1 & 13.6 & -- & 27.7 & 10.1 & 5.2 & . & 17.9 & 5.6 & 1.6 & 1.2 \\
\hline & 2001 & 17,155 & 22.7 & 8.7 & - & 26.1 & 13.1 & 4.4 & . & 14.7 & 8.0 & 2.2 & 0.3 \\
\hline \multirow[t]{3}{*}{ Korea } & 1985 & 2,559 & 0.0 & 41.6 & 8.0 & -- & 10.8 & 8.4 & 16.5 & 7.3 & 7.3 & 0.1 & \\
\hline & 1995 & 40,346 & 25.5 & 23.5 & 6.1 & -- & 7.9 & 3.5 & 13.4 & 10.7 & 6.1 & 3.1 & 0.2 \\
\hline & 2001 & 55,748 & 42.0 & 16.4 & 6.5 & -- & 5.3 & 3.5 & 6.9 & 12.0 & 3.8 & 3.4 & 0.3 \\
\hline \multirow[t]{3}{*}{ Laos } & 1985 & 17 & 57.2 & 3.6 & 0.0 & 0.0 & 0.0 & 0.0 & 10.5 & 0.0 & 7.1 & 21.7 & . \\
\hline & 1995 & 190 & 3.4 & 0.5 & 0.0 & 0.0 & 0.0 & 0.0 & 5.6 & 9.5 & 36.7 & 44.2 & . \\
\hline & 2001 & 220 & 3.4 & 0.1 . & 0.5 & 0.2 & 0.1 & 0.0 & 0.2 & 1.9 & 40.6 & 53.0 & . \\
\hline \multirow[t]{3}{*}{ Malaysia } & 1985 & 6,844 & 2.9 & 2.5 & 0.8 & 18.0 & 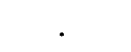 & 5.7 & 54.6 & 7.0 & 8.0 & 0.0 & 0.4 \\
\hline & 1995 & 37,642 & 5.5 & 9.9 & 6.9 & 6.7 & & 1.7 & 51.1 & 7.8 & 8.6 & 0.5 & 1.3 \\
\hline & 2001 & 46,759 & 13.3 & 10.8 & 3.7 & 8.8 & 1.1. & 2.0 & 43.0 & 9.0 & 6.6 & 1.1 & 1.7 \\
\hline \multirow[t]{3}{*}{ Mongolia } & 1985 & 4 & 52.6 & 0.0 & & & 0.0 & & . & . & 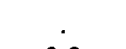 & 47.4 & . \\
\hline & 1995 & 111 & 90.7 & 0.5 & 0.0 & 8.7 & 0.1 & $0.0^{\circ}$ & 0.0 & . & 0.0 & 0.0 & . \\
\hline & 2001 & 242 & 98.8 & 0.1 & 0.0 & 1.0 & 0.0 & 0.0 & 0.0 & . & 0.1 & 0.0 & . \\
\hline \multirow[t]{3}{*}{ Philippines } & 1985 & 1,071 & 9.9 & 19.5 & 2.1 & 14.1 & 21.5 & . & 18.5 & 9.7 & 5.6 & 0.0 & \\
\hline & 1995 & 4,645 & 5.9 & 18.6 & 1.7 & 13.1 & 9.9 & . & 23.7 & 13.9 & 12.5 & 0.5 & 0.2 \\
\hline & 2001 & 14,736 & 13.2 & 13.4 & 1.0 & 12.3 & 12.5 & & 17.3 & 22.1 & 7.7 & 0.5 & \\
\hline
\end{tabular}


Appendix Table A6.1 Continued

\begin{tabular}{|c|c|c|c|c|c|c|c|c|c|c|c|c|c|}
\hline \multirow[b]{2}{*}{$\begin{array}{l}\text { Origin of } \\
\text { Regional Exports }\end{array}$} & \multirow[b]{2}{*}{ Year } & \multirow{2}{*}{$\begin{array}{c}\text { Regional } \\
\text { Exports } \\
\text { (\$ Mill.) }\end{array}$} & \multicolumn{11}{|c|}{ Share of Regional Exports Destined For (\%) } \\
\hline & & & China & $\begin{array}{l}\text { Hong } \\
\text { Kong }\end{array}$ & Indonesia & $\begin{array}{c}\text { Rep. of } \\
\text { Korea }\end{array}$ & Malaysia & Philippines & Singapore & $\begin{array}{l}\text { Taiwan } \\
\text { (China) }\end{array}$ & Thailand & Vietnam & Others* \\
\hline \multirow[t]{3}{*}{ Singapore } & 1985 & 6,032 & 4.0 & 24.0 & 13.9 & 4.4 & 32.3 & 2.1 & - & 4.6 & 11.4 & 0.4 & 2.9 \\
\hline & 1995 & 38,979 & 8.7 & 25.9 & 6.1 & 5.6 & 24.7 & 3.3 & -- & 7.6 & 10.7 & 3.7 & 3.8 \\
\hline & 2001 & 41,806 & 12.3 & 22.4 & 9.0 & 7.2 & 22.2 & 4.3 & - & 8.1 & 6.8 & 5.5 & 2.2 \\
\hline \multirow[t]{3}{*}{ Taiwan, China } & 1985 & 4,994 & · & 53.7 & 5.8 & 6.7 & 6.5 & 3.7 & 17.5 & - & 5.8 & 0.0 & 0.3 \\
\hline & 1995 & 49,069 & 30.1 & 34.1 & 0.0 & 5.2 & 8.1 & 3.1 & 10.4 & -- & 7.0 & 1.8 & 0.2 \\
\hline & 2001 & 62,477 & 43.8 & 22.2 & 2.6 & 6.9 & 6.7 & 2.6 & 7.9 & - & 4.2 & 3.0 & 0.1 \\
\hline \multirow[t]{3}{*}{ Thailand } & 1985 & 1,982 & 13.3 & 14.9 & 2.4 & 7.7 & 22.0 & 2.8 & 27.5 & 7.4 & -- & 0.0 & 2.0 \\
\hline & 1995 & 17,548 & 9.2 & 15.5 & 4.2 & 5.3 & 11.6 & 2.4 & 36.6 & 8.5 & -- & 2.5 & 4.1 \\
\hline & 2001 & 24,359 & 19.3 & 14.4 & 6.2 & 6.5 & 12.0 & 3.7 & 21.2 & 9.0 & -- & 3.6 & 4.2 \\
\hline \multirow[t]{3}{*}{ Vietnam } & 1985 & 182 & 0.0 & 54.7 & 3.3 & 0.0 & 7.4 & 0.0 & 34.1 & 0.0 & 0.3 & -- & 0.1 \\
\hline & 1995 & 1,916 & 17.3 & 9.1 & 8.2 & 10.1 & 6.5 & 2.2 & 23.4 & 14.1 & 2.2 & - & 6.7 \\
\hline & 2001 & 4,354 & 23.2 & 6.0 & 6.9 & 8.9 & 7.3 & 6.4 & 19.5 & 9.6 & 7.5 & -- & 4.6 \\
\hline \multirow[t]{3}{*}{ All Above } & 1985 & 44,067 & 24.7 & 15.1 & 4.4 & 5.8 & 15.5 & 2.4 & 13.7 & 11.3 & 4.5 & 0.4 & 2.1 \\
\hline & 1995 & 314,496 & 28.9 & 6.4 & 3.8 & 12.8 & 12.0 & 1.5 & 12.4 & 15.6 & 5.6 & 0.6 & 0.5 \\
\hline & 2001 & 418,007 & 30.6 & 5.0 & 4.1 & 13.3 & 11.2 & 3.5 & 10.0 & 14.9 & 5.8 & 1.0 & 0.5 \\
\hline
\end{tabular}

* Includes Brunei, Cambodia, Lao PDR and Mongolia

Source: Partner country import statistics drawn from IMF Direction of Trade data 


\section{Trade Trends 7 \\ How "Intense" is East Asian Intra-Regional Trade?}

\section{$\underline{\text { Key Point }}$}

Even after the influence of their relatively close proximity is accounted for East Asian intra-trade must be generally classified as highly "intense." Also, the intensity of trade within the region increased markedly over both the full 1985-2001, and the shorter 1995-2001 period. For example, in 1985 only 40 percent of all East Asian bilateral trade flows were greater than expected, based on the countries' shares in world trade, as opposed to 61 percent in 2001. Trade relations between most East Asian countries have been growing sharply in terms of their intensity and importance!

Several statistical indices can provide useful insights concerning aspects of East Asian intra- trade. One such measure -- the so called "trade intensity" or TI index - has been used to determine whether the value of trade between two countries is greater, or smaller, than should be expected based on their relative importance in world trade. For example, IMF Direction of Trade statistics report that approximately 46 percent of Indonesia's 2001 exports went to other East Asian countries. Is this above, or below, what should be expected on the basis of the partners' relative size in global trade? Is China's year 2001 trade with other regional countries, about 32 percent of total exports, higher or lower than should be expected? Another question of importance is whether the intensity of trade between East Asian countries has been increasing over time. If so, what is the magnitude of the change?

In previous applications the trade intensity index has been defined as;

$$
T_{i j}=\left[x_{i j} / X_{i t}\right] \div\left[x_{w j} / X_{w t}\right] \text {, }
$$

where $x_{i j}$ and $x_{w j}$ are the values of $i^{\prime} ! 3$ exports and world exports to $j, X_{i t}$ is $i$ 's total exports, and $X_{w t}$ are total world exports. As such, the index reflects the ratio of the share of country $i$ 's exports going to country $j$, relative to the share of world trade destined for country j (see Frankel 1997, Anderson 1983, or Drysdale and Garnaut 1982 for illustrative applications). ${ }^{7}$ An index of more (less) than unity has been interpreted as indicating a bilateral trade flow is larger (smaller) than expected given the partner country's importance in world trade. However, a clear limitation of the standard trade intensity index is that it fails to account for distances between individual countries. With all other things equal, countries that are near to each other should be expected to have more "intense" trade relations than those that are geographically distant. This point has long been recognized, and validated, in so called "gravity models" of international trade (see Linnemann 1966, Tinbergen 1962 and Pulliainen 1963), but the influence of distance has yet to be properly accounted for in previous analyses employing the trade intensity index.

In recognition of this point, a modified application of the standard TI index, which accounts for geographic distance, is used for analysis of East Asian countries' trade. This approach first employs a regression equation to determine how trade intensities between countries normally vary with distance. The regression was estimated using bilateral trade statistics from a randomly drawn sample of both regional and non-regional countries and took the form,

$$
\log \left(T_{i j}\right)=0.6245-0.00015 \text { (distance), }
$$

$$
\mathrm{R}^{2}=.672
$$

7 Several investigations have jointly computed trade intensity indices using both import and export statistics. These data could produce somewhat different results if a country's trade (that is, exports versus imports) was seriously out of balance. Also, some modified versions of equation 7.1 have subtracted country $j$ 's imports from the world trade total $\left(X_{w t}\right)$ to account for the fact that a country cannot trade with itself. Given the relatively small size of most East Asian countries this "adjustment" would not have produced dissimilar results to those shown in Table 7.1. 
where $t$ values (which are all statistically significant at the 99 percent confidence level) are shown in parentheses. $^{8}$ In the above, distances were expressed in miles between the capitals of exporting and importing countries with the exceptions of the United States and Canada. Here, if trade involved a South or East Asian country, distance was measured by the number of miles to San Francisco or Vancouver.

Next, the regression equation was used to project the "expected" trade intensity $\left(T_{i j}^{*}\right)$ given the geographic distance between two countries. The ratio of the actual to expected trade intensities was then calculated,

$$
R_{i j}=T_{i j} \div T_{i j}{ }^{*}
$$

If this ratio exceeds unity the bilateral trade intensity between the two countries is higher than expected given the distance that separates them. Ratios below unity reflect a lower than expected trade intensity. Finally, the actual value of the expected distance adjusted trade intensity index can be derived from,

$$
T_{i j}^{*}=T_{i j} \div R_{i j}
$$

If the value of the traditional trade intensity (equation 7.1) index fails to exceed $\mathrm{T}_{\mathrm{ij}}{ }^{*}$ the intensity of bilateral trade must be considered as lower than expected even if the former exceeds unity.

The top one-half of Table 7.1 reports values for the expected distance adjusted trade intensity indices between East Asian countries in 2001, while the lower half shows values for the traditional index. In the case of the latter, situations where the traditional index exceeds unity, but still falls below the critical value of the distance adjusted index, are marked with an asterisk. The intention here is to quickly identify situations where the traditional index would inappropriately lead to the conclusion that trade between two East Asian countries was more intense than expected. Table 7.2 provides information on traditional trade intensity indices for 1985 and 1995 and indicates whether or not they exceeded their distance adjusted expected values. ${ }^{\text {' }}$

Two points are evident from these comparisons,

- First, any analysis of the intensity of trade between East Asian countries must account for the influence of the distance. Average expected distance adjusted TI indices for East Asia ranged from a high of 2.89 for Cambodia to a low of 2.22 for Korea. These values far exceed unity which was the "cut off" used in traditional trade intensity analyses. In 2001 , there were 15 bilateral trade flows where the standard $\mathrm{TI}$ index exceeded unity, but which fell short of the expected distance adjusted index. In these cases, the traditional approach would have misclassified the intensity of trade as higher than expected although the reverse was true.

${ }^{8}$ To be included in the sample countries had to be classified by the World Bank (2001) as being either middle or high income countries. Low income countries were excluded since a disproportionately high number are located in Africa and appear to have abnormally high transport costs that could distort the normal relation between distance and trade (Amjadi and Yeats 1995). Even more important is the fact that many of the low income countries fail to report timely trade data so the statistics in IMF DOT may often be unreliable estimated trade data. The mileage statistics used in the regression are "great circle" estimates of distance that account for features like the curvature of the earth between two geographic points. These estimates were taken from a US Department of Agriculture web page that can be found at www.wcrl.ars.usda.gov/cec/java/lat-long.html. Tests involving a linear regression equation were distinctly inferior to equation 7.2 and could only "explain" about one-third the total variation in the data.

${ }^{9}$ Some extremely high TI index values reported in Table 7.2, like that shown for Cambodia's trade with Vietnam, result from the partner's very small share of global imports, and the fact that bilateral trade relations were still distorted by unusual social, economic, or governmental problems, 
Table 7. 1 East Asian Distance Adjusted and Traditional Trade Intensity Ratios in 2001

\begin{tabular}{|c|c|c|c|c|c|c|c|c|c|c|c|c|}
\hline \multirow[b]{2}{*}{ Exporter } & \multicolumn{12}{|c|}{ Expected Distance Adjusted Trade Intensity Indices } \\
\hline & Cambodia & China & $\begin{array}{l}\text { Hong } \\
\text { Kong }\end{array}$ & Indonesia & Korea & Malaysia & Philippines & Singapore & $\begin{array}{c}\text { Taiwan, } \\
\text { China }\end{array}$ & Thailand & Vietnam & Japan \\
\hline Cambodia & -- & 2.05 & 3.02 & 2.76 & 1.91 & 3.40 & 2.82 & 3.29 & 2.52 & 3.76 & 3.35 & 1.63 \\
\hline China & 2.05 & -- & 2.76 & 1.36 & 3.43 & 1.66 & 2.29 & 1.61 & 2.91 & 2.07 & 2.55 & 2.69 \\
\hline Hong Kong & 3.02 & 2.76 & -- & 2.10 & 2.69 & 2.46 & 3.31 & 2.42 & 3.53 & 2.90 & 3.49 & 2.27 \\
\hline Indonesia & 2.76 & 1.36 & 2.10 & -- & 1.35 & 3.27 & 2.32 & 3.48 & 1.85 & 2.56 & 2.20 & 1.21 \\
\hline Korea & 1.91 & 3.43 & 2.69 & 1.35 & -- & 1.57 & 2.40 & 1.54 & 3.07 & 1.89 & 2.34 & 3.29 \\
\hline Malaysia & 3.40 & 1.66 & 2.46 & 3.27 & 1.57 & -- & 2.48 & 3.94 & 2.10 & 3.27 & 2.72 & 1.34 \\
\hline Philippines & 2.82 & 2.29 & 3.31 & 2.32 & 2.40 & 2.48 & -- & 2.52 & 3.27 & 2.62 & 2.89 & 2.36 \\
\hline Singapore & 3.29 & i.ói & 2.42 & 3.48 & 1.54 & 3.94 & 2.52 & -- & 2.10 & 3.10 & 2.63 & 1.34 \\
\hline Taiwan, China & 2.52 & 2.91 & 3.53 & 1.85 & 3.07 & 2.10 & 3.27 & 2.10 & -. & 2.45 & 2.95 & 2.68 \\
\hline Thailand & 3.76 & 2.07 & 2.90 & 2.56 & 1.89 & 3.27 & 2.62 & 3.10 & 2.45 & -- & 3.41 & 1.57 \\
\hline Vietnam & 3.35 & 2.55 & 3.49 & 2.20 & 2.34 & 2.72 & 2.89 & 2.63 & 2.95 & 3.41 & -- & 1.91 \\
\hline \multirow[t]{2}{*}{ Average } & 2.89 & 2.27 & 2.87 & 2.33 & 2.22 & 2.68 & 2.69 & 2.66 & 2.67 & 2.80 & 2.85 & 2.23 \\
\hline & \multicolumn{12}{|c|}{ Traditional Trade Intensity Indices } \\
\hline Cambodia & -- & $1.55^{*}$ & 0.34 & 0.16 & 0.76 & $2.36^{*}$ & $1.14^{*}$ & 4.27 & $1.29^{*}$ & $2.48^{*}$ & 9.41 & 0.59 \\
\hline China & $1.01^{*}$ & -- & 10.22 & 2.88 & 5.92 & 1.96 & $1.41^{*}$ & 2.33 & 2.99 & 3.10 & 2.86 & 5.88 \\
\hline Hong Kong & 9.34 & 12.11 & - & 5.95 & 3.80 & 6.78 & 12.95 & 6.28 & 6.53 & 4.79 & 5.95 & 2.79 \\
\hline Indonesia & 0.75 & 0.10 & $1.14^{*}$ & -. & 13.08 & 7.58 & 7.39 & $3.14^{*}$ & 8.41 & 7.48 & 3.54 & 6.08 \\
\hline Korea & $1.45^{*}$ & 10.96 & 2.70 & 8.45 & - & 3.86 & 7.31 & 3.14 & 8.63 & 4.48 & 6.97 & 11.57 \\
\hline Malaysia & 0.82 & 4.27 & $2.19^{*}$ & 5.91 & 6.83 & .- & 5.11 & 24.24 & 7.96 & 9.56 & 2.80 & 5.83 \\
\hline Philippines & 0.28 & 0.14 & $2.23^{*}$ & $1.30^{*}$ & 7.83 & 9.17 & -- & 8.01 & 15.97 & 9.10 & 0.96 & 12.45 \\
\hline Singapore & 20.44 & 4.23 & 4.87 & 15.51 & 5.96 & 21.31 & 11.81 & -- & 7.61 & 10.60 & 14.88 & 4.90 \\
\hline Taiwan, China & $2.44^{*}$ & 13.80 & 4.43 & 4.09 & 5.22 & 5.90 & 6.48 & 4.36 & -- & 5.92 & 7.49 & 12.66 \\
\hline Thailand & 33.05 & 4.98 & $2.34^{*}$ & 7.93 & 4.04 & 8.61 & 7.58 & 9.55 & 6.32 & -- & 7.23 & 10.18 \\
\hline Vietnam & 35.27 & 5.22 & 0.85 & 7.79 & 4.80 & 4.58 & 11.57 & 7.69 & 5.94 & 7.62 & -- & 2.64 \\
\hline
\end{tabular}

* Although the traditional trade intensity index exceeds unity in this case it falls below the expected distance adjusted index for the two trading partners. As such, the intensity to trade is lower than expected given the geographic distance between the two trading partners.

Source: Based on data from International Monetary Fund, Direction of Trade (DOT) Statistics 
Table 7.2 East Asian Traditional Trade Intensity Ratios in 1985 and 1995

\begin{tabular}{|c|c|c|c|c|c|c|c|c|c|c|c|c|}
\hline & \multicolumn{12}{|c|}{ Trading Partner } \\
\hline Exporter & Cambodia & China & $\begin{array}{l}\text { Hong } \\
\text { Kong }\end{array}$ & Indonesia & Korea & Malaysia & Philippines & Singapore & $\begin{array}{l}\text { Taiwan } \\
\text { China }\end{array}$ & Thailand & Vietnam & Japan \\
\hline & \multicolumn{12}{|c|}{1985 Traditional Trade Intensity Indices } \\
\hline Cambodia & -- & 8.16 & 0.00 & 0.00 & 0.00 & 16.37 & 0.00 & 19.16 & 0.00 & 0.00 & $1,719,58$ & 0.78 \\
\hline China & $1.15^{*}$ & -- & 17.74 & 0.89 & 0.00 & $1.11 *$ & 4.26 & 5.79 & 0.05 & 0.92 & 0.00 & 3.47 \\
\hline Hong Kong & 0.00 & 17.00 & -- & 2.21 & $1.17^{*}$ & $1.21^{*}$ & 3.82 & $2.16^{*}$ & 0.13 & $1.52^{*}$ & 9.82 & 0.66 \\
\hline Indonesia & 0.00 & 0.30 & $1.27^{*}$ & - & 2.28 & 0.68 & 3.96 & 6.70 & 0.08 & 0.95 & $1.39^{*}$ & 7.19 \\
\hline Korea & 0.00 & 0.00 & 3.50 & $1.27^{*}$ & -- & 2.43 & 2.95 & $1.24^{*}$ & 0.01 & $1.03^{*}$ & 0.00 & $2.33^{*}$ \\
\hline Malaysia & 4.49 & 0.68 & 0.91 & 0.84 & 3.80 &.- & 8.85 & 14.88 & 0.00 & 7.45 & 0.34 & 3.82 \\
\hline Philippines & 0.00 & $1.15^{*}$ & $2.74^{*}$ & 0.78 & $1.05^{*}$ & 6.16 &.- & 4.15 & 0.01 & 3.92 & $1.49^{*}$ & 2.95 \\
\hline Singapore & 38.60 & 0.95 & 4.32 & 7.23 & 0.80 & 25.39 & 3.54 & -- & 0.75 & 9.06 & 29.92 & 1.46 \\
\hline Taiwan, China & 0.00 & $2.02^{*}$ & 0.01 & 0.00 & 0.00 & 0.05 & 0.00 & 0.00 & - & 0.08 & 0.00 & 0.00 \\
\hline Thailand & 0.00 & 2.49 & 2.74 & $1.19^{*}$ & $1.21^{*}$ & 8.16 & 2.76 & 6.09 & 0.01 &.- & 0.00 & 2.08 \\
\hline \multirow[t]{2}{*}{ Vietnam } & 309.55 & 0.00 & 4.67 & 0.06 & $1.45^{*}$ & 0.00 & 0.00 & 4.02 & 0.00 & 0.13 & -- & 0.73 \\
\hline & \multicolumn{12}{|c|}{1995 Traditional Trade Intensity Indices } \\
\hline Cambodia & -- & 0.00 & 0.01 & 0.21 & 0.00 & $2.41^{*}$ & 0.00 & 0.00 & 0.00 & $2.14^{*}$ & $3.17^{*}$ & 0.04 \\
\hline China & $1.65^{*}$ & -- & 11.71 & 3.82 & 8.26 & 1.84 & 4.24 & 3.16 & $1.25^{*}$ & 4.07 & 2.90 & 2.97 \\
\hline Hong Kong & $1.07^{*}$ & 25.57 & -- & 2.34 & 2.98 & $1.90^{*}$ & 7.10 & $3.83^{*}$ & $2.05^{*}$ & 3.22 & $2.20^{*}$ & 0.95 \\
\hline Indonesia & 7.51 & 3.07 & $1.76^{*}$ & -- & 12.37 & 4.91 & 7.67 & 8.33 & $1.55^{*}$ & 5.28 & 2.92 & 4.37 \\
\hline Korea & 0.00 & 5.62 & 4.11 & 9.05 & -- & 5.04 & 7.31 & 7.18 & 6.69 & 6.70 & 6.47 & $2.12^{*}$ \\
\hline Malaysia & 5.01 & 1.96 & 2.59 & 5.04 & 5.04 &.- & 5.42 & 27.77 & 5.81 & 13.46 & $2.18^{*}$ & 1.94 \\
\hline Philippines & 0.08 & 0.92 & $2.29^{*}$ & 2.79 & 4.70 & 3.86 & -- & 7.69 & 19.05 & 15.51 & 4.26 & 2.45 \\
\hline Singapore & 20.15 & 1.79 & 4.15 & 5.77 & 5.06 & 40.96 & 10.01 & -- & 6.91 & 19.98 & 9.07 & $1.21^{*}$ \\
\hline Taiwan, China & 0.01 & 4.75 & 4.99 & 0.19 & 5.31 & 4.99 & 5.25 & 3.85 & -- & 3.39 & 0.44 & 3.11 \\
\hline Thailand & 84.51 & 2.22 & $2.38^{*}$ & 5.08 & 3.10 & 7.83 & 4.50 & 15.53 & $2.21^{*}$ & -- & 5.55 & 2.84 \\
\hline Vietnam & 309.55 & 4.34 & $2.79^{*}$ & 10.27 & 0.00 & 4.56 & 12.45 & 10.30 & 3.62 & $2.54^{*}$ & -- & 4.56 \\
\hline
\end{tabular}

* Although the traditional trade intensity index exceeds unity in this case it falls below the expected distance adjusted index for the two trading partners. As such, the intensity to trade is lower than expected given the geographic distance between the two trading partners.

Source: Based on data from International Monetary Fund, Direction of Trade (DOT) Statistics 
- Second, in spite of this qualification, the statistics indicate East Asian intra-trade must be generally classified as highly "intense." This conclusion follows from the fact that TI indices for 85 (61 percent) of the possible 140 bilateral trade flows among regional countries exceed their critical distance adjusted expected values, often by a considerable margin. Also, the evidence strongly suggests that the intensity of trade between East Asian countries has been increasing markedly. For example, in 1985 only 40 percent of the distance adjusted TI indices exceeded their critical values as opposed to 61 percent in 2001. The general trend toward more intense trade continued in the recent 1995-2001 period (China is an exception - see Table 7.2). In 1995, for example, the TI indices for 78 bilateral trade flows (excluding Japan) exceeded their critical values as opposed to 85 in 2001 . Also, in 2001 the median value for all East Asian trade intensity rose to 5.1 from 4.3 in 1995. Trade relations between East Asian countries have been growing sharply in terms of their iniensity and importance!

\section{Trade Trends 8}

Have East Asian Trade Profiles Become More Complementary?

\section{$\underline{\text { Key Point }}$}

A trade "complementarity" index shows growing similarities between the types of goods East Asia exports, and the goods imported, was a potent factor promoting the expansion of intra-trade. The current East Asian values for this index are very similar to those for countries, like the original EU (6) members at the time of the formation of the European Economic Community.

One possible explanation for the impressive expansion of East Asian intra-trade, which is reflected in the previous analyses, is that regional countries' export and import profiles became more "complementary" over time. That is, in the 1970s and early 1980s, the potential for intra-trade may have been constrained by the fact that niany East Asian countries could not competitively export the types of goods that constituted the region's major imports. An important question is whether the region's export and import profiles became more similar over time and, therefore, facilitated the growth in intra-trade.

The so called "trade complementarity index" can show how well the export profile of one country, or group of countries, matches the import profiles of others. Furthermore, changes in the index over time can help determine whether their trade profiles are becoming more, or less, compatible. The index of trade complementarity between two countries $k$ and $j\left(C_{k j}\right)$ is defined as,

$$
C_{i j}=100-\sum\left(\left|m_{i k}-x_{i j}\right| \div 2\right)
$$

where $x_{i j}$ is the share of good $i$ in the exports of country $j$, and $m_{i k}$ is the share of good $i$ in the imports of country $k$. The index is zero when no good exported by one country is imported by the other, and 100 when the export-import shares exactly match. As such, it is assumed that higher index values indicate more favorable prospects for a successful trade arrangement between countries. ${ }^{10}$ Michaely (1994) used the

\footnotetext{
${ }^{10}$ Several caveats should be noted. First, use of the index presumes that a country can expand production and trade of its exports on a relatively constant cost basis. Second, considerations must be given to relevant factors like economic geography. High complementarity indices may be misleading if the countries are geographically distant, or have other natural barriers that make trade unprofitable. Third, relative size differences can be very important. If exporter $i$ can only supply a very small share of country $j$ 's import needs this would be a negative factor, even if their trade complementarity indices were quite high. Finally, the index assumes that countries assign equal priorities for trade expansion to all goods. If there are different priorities for (say) manufactures as opposed to raw materials this complicates the use of the index.
} 
index to assess prospects for Latin American trade arrangements, while Yeats (1998) employed the measure to analyze the compatibility of Sub-Saharan African countries' intra-trade.

Table 8.1 reports 1985, 1995 and 2001 complementarity indices for trade between individual East Asian countries. Although indices for several smaller counties, like Brunei, Cambodia, Laos PDR, and Mongolia are low and essentially static, dramatic increases occur in the indices for most other countries. In fact, the latter rose by about 16 points over its value (51.2) in the mid-1980s. The trade complementarity indices for five countries, namely, Hong Kong, Malaysia, Philippines, Thailand and Taiwan rose by more than 50 percent, while Indonesia's indices more than doubled. Overall, the evidence presented in Table 8.1 shows growing similarities between the goods East Asia exports, and the goods other regional countries import, was a potent factor promoting the expansion of intra-trade.

An interesting, although somewhat dissimilar, pattern emerges for trade with the non-regional partners. The indices for trade with the EU (15) registered only a slight increase (under 4 points) since the mid-1980s, while the increase for NAFTA trade was less than 8 points. The indices for trade with Japan, however, registered about the same magnitude of change as those for East Asian intra-trade. These data strongly suggest that the trade profiles of the regional countries changed in a way that allowed them to capitalize on opportunities in other Asian markets. This should not be surprising, however, since statistics compiled and analyzed by UNCTAD (1990, pp. 234-237) show a relatively strong interrelation exists between changes in national income and changes in the structure of exports. ${ }^{11}$ In general, as income levels rise the structure of a country's exports change to more closely parallel the structure of world trade. As a result of its rising income levels, East Asia's exports more closely matched regional imports, that is, trade became more complementary.

An interesting question concerns similarities between the statistics shown in Table 8.1 with indices for countries that previously formed regional trade arrangements. . Yeats (1998) provides relevant information by reporting complementarity indices for "successful" and "failed" regional arrangements computed using trade data from the year in which the agreements were implemented. The indices ranged from values of 7 to 22 for previously failed arrangements (in the sense that the agreements were eventually dissolved) like LAFTA and the original Andean Pact, and from values of 53 to 64 for the EU(6) and NAFTA.

Finally, the increase in East Asia's trade complementarity indices no doubt were an important factor fueling the rapid expansion of intra-regional trade. In 2001, trade among the emerging East Asian countries was approximately $\$ 418$ billion. If Japan were included the value would be about $\$ 563$ billion. This is approximately $\$ 30$ billion higher than the current intra-trade of the six original founders (BelgiumLuxembourg, Netherlands, France, Germany, and Italy) of the European Union, and about $\$ 70$ billion below NAFTA intra-trade. In contrast, intra-trade of MERCOSUR members is under $\$ 20$ billion.

${ }^{11}$ These conclusions were based on the use of a trade structure (TS) index that took the form,

$$
\mathrm{TS}_{\mathrm{j}}=\left[\Sigma\left|\mathrm{h}_{\mathrm{ij}}-\mathrm{h}_{\mathrm{i}}\right|\right] \div 2,
$$

where $h_{i j}$ is the share of commodity $i$ in the exports of $j$, and $h_{i}$ is the share of $i$ in total world exports. Lower values of the index indicate a country's export structure more closely matches that of world trade. For example, the UNCTAD (1990) document reported a mid-1980s TS index value of 0.429 for Japan, 0.605 for Singapore, and 0.909 for Lao PDR. 
Table 8. 1 Complementarity Indices for East Asian Trade

\begin{tabular}{|l|c|c|c|c|c|c|}
\hline \multirow{2}{*}{ Trader } & \multicolumn{3}{|c|}{ Regional Exports (\$ million) } & \multicolumn{3}{|c|}{ Trade Complementarity Index } \\
\cline { 2 - 7 } & 1985 & 1995 & 2001 & 1985 & 1995 & 2001 \\
\hline REGIONAL TRADE & & & & & & \\
Brunei & 922 & 951 & 1,192 & 5.0 & 8.1 & 7.6 \\
Cambodia & 3 & 276 & 182 & 10.2 & 8.2 & 6.7 \\
China & 10,867 & 90,799 & 127,796 & 33.4 & 44.3 & 47.0 \\
Hong Kong, China & 6,637 & 20,016 & 20,981 & 32.0 & 53.6 & 54.9 \\
Indonesia & 1,953 & 12,008 & 17,155 & 16.7 & 30.9 & 40.2 \\
Korea & 2,559 & 40,346 & 55,748 & 47.3 & 64.9 & 67.7 \\
Lao, PDR & 17 & 190 & 220 & 7.7 & 8.5 & 8.0 \\
Malaysia & 6,844 & 37,642 & 46,759 & 29.9 & 50.1 & 56.4 \\
Mongolia & 4 & 111 & 242 & 6.5 & 8.7 & 7.6 \\
Philippines & 1,071 & 4,645 & 14,736 & 28.1 & 43.8 & 47.2 \\
Singapore & 6,032 & 38,979 & 41,806 & 47.5 & 53.0 & 61.3 \\
Taiwan, China & 4,994 & 49,069 & 62,477 & 43.4 & 62.2 & 68.5 \\
Thailand & 1,982 & 17,548 & 24,359 & 29.3 & 48.5 & 57.3 \\
Vietnam & 182 & 1,916 & 4,354 & 13.2 & 16.2 & 23.5 \\
All Above Countries & 44,067 & 314,496 & 418,007 & 51.2 & 65.2 & 67.3 \\
& & & & & & \\
NON-REGIONAL TRADE & & & & & & \\
East Asia-Japan & 35,280 & 118,717 & 144,884 & 51.9 & 60.1 & 65.4 \\
East Asia - NAFTA & 61,368 & 196,118 & 309,066 & 53.8 & 63.0 & 61.4 \\
East Asia-EU (15) & 22,352 & 124,015 & 182,182 & 56.4 & 59.2 & 59.8 \\
& & & & & & \\
\hline
\end{tabular}

Source: Computations based on UN COMTRADE data

\section{Trade Trends 9}

Competitive Factors and the Change in Regional Exports

\section{$\underline{\text { Key Point }}$}

An empirical procedure is used to isolate the effects of demand, diversification and competitiveness changes on East Asia's regional exports. The results show that a markedly improved ability to compete played a major role in the expansion of East Asian intra-trade since the mid-1980s. Separate tests for the 1995-2001 period indicate East Asian regional market shares continued to grow in spite of the effects of the financia! crisis. Similar analyses involving exports to the EU(15), NAFTA and Japan shows East Asia's improved competitiveness also occurred in major global markets.

The previous analyses showed East Asian regional trade expanded at a relatively rapid pace since the mid-1980s. Factors relating to both supply and demand influenced these trade changes, and an important question concerns the extent to which an improvement in competitiveness contributed to this favorable performance. This question can be addressed by decomposing East Asian export growth into three factors, two of which relate to demand changes and changes in the ability to compete. ${ }^{12}$ The influence of demand for a specific product can be measured by the change in the total (global) value of regional

${ }^{12}$ A detailed description and early application of this procedure can be found in GATT (1966). The analysis also constituted a large part of Irving Kravis' (1970) classic analysis of the influence of trade on the $20^{\text {th }}$ century growth of developing countries. 
imports of the item. In calculating the influence of this factor, one assumes that a given country (like Thailand) maintains its regional trade share for the commodity. Specifically, if $D_{o, j}$ and $D_{i, j}$ represent regional trade in product $j$, at time period $o$ and $t$ respectively, the change in a specific country's exports attributed solely to demand $\Delta \mathrm{E}_{\mathrm{d}, \mathrm{i}}$ is:

$$
\Delta E_{d, i}=\Sigma\left(s_{o, j}\right) \times\left(D_{t, j}-D_{o, j}\right)
$$

where $s_{0, j}$ is the share of country $i$ in regional imports of product $j$ (defined at the four-digit level of the Revision 2 SITC) from all countries in the base period $o$, and the summation is over all goods traded. Therefore, the above equation shows the change in country i's exports that would have occurred if only changes in demand took place.

Second, the change in the competitive position of country $i$ is measured by the difference between the exports that would have occurred if the country's market share had not changed, and those regional exports that were in fact realized. This competitive factor $\left(\Delta E_{c, i}\right)$ is:

$$
\Delta E_{c, i}=\Sigma\left(s_{L j}-s_{o, j}\right)\left(D_{L, j}\right)
$$

where $s_{\mathrm{t}, j}$ is the share of the country in regional imports of the product in period $t$, and the summation is over all goods imported. Any differences between changes in a country's total exports and the sum of these two "demand" and "competitive" factors are due to product diversification."

Table 9.1 summarizes the results when these equations was applied to statistics on all four-digit SITC products exported by the East Asian countries to regional markets in 1985, 1995 and 2001. The table shows the value of exports in each year along with changes due to the supply and demand factors. For example, China's regional exports totaled $\$ 90.8$ billion in 1995 and $\$ 127.8$ billion in 2001 . The 1995-2001 demand change factor generated a potential increase in annual exports worth $\$ 2.9$ billion. However, China's improved ability to compete, as reflected in its higher regional market shares (particularly for products like telecommunications and office machinery components), resulted in a further increase of $\$ 30.8$ billion. The sum of the supply and demand induced changes ( $\$ 33.652$ billion) falls about $\$ 3.345$ billion short of the total 1995-2001 change in China's exports. As noted, this difference reflects China's diversification into new product lines that were not exported in 1995.

Several important positive points are evident from the statistics in Table 9.1. First, in both the full 1985-2001, and shorter 1995-2001 periods, East Asian countries registered strong competitive gains in regional trade. Over the recent interval, which covered the period of the financial crisis, competitive regional export gains (about $\$ 51.802$ billion) exceeded gains associated with increased demand by approximately $\$ 13$ billion. Second, although China accounted for about one-half of the 1985-2001 competitive gains, only Brunei (whose major regional export is petroleum) experienced losses due to erosion of its market shares. Third, on a percentage basis, market share changes more than doubled the exports of the Philippines and Vietnam - an expansion that far exceeded the 34 percent increase associated

${ }^{13}$ An illustrative example may help explain this approach. Assume country $\mathrm{i}$ exports one product $\mathrm{j}$ and has a 20 percent share of the regional markets with exports $\$ 20$ million in 1995 , and a 25 percent share with exports of $\$ 37.5$ million in 2001 . During this period regional demand for j rose from $\$ 100$ to $\$ 150$ million. The change in i's exports attributed solely to changes in demand would be:

$$
\Delta \mathrm{E}_{\mathrm{d}, \mathrm{i}}=.20(\$ 150-\$ 100)=\$ 10 \text { million }
$$

while the change due to the competitive factor is:

$$
\Delta \mathrm{E}_{\mathrm{c}, \mathrm{i}}=(.25-.20) \times \$ 150=\$ 7.5 \text { million }
$$

This example assumes that the country experiences no diversification in its exports. 
with China's improved competitive ability. Overall, the data show that East Asian countries experienced a marked improvement in their competitive position in regional markets. ${ }^{14}$

For East Asia as a whole the diversification into new product lines added about $\$ 30.8$ billion to regional trade over 1985-2001 which represents about 7 percent of current exports. Measured as a percentage of 2001 exports the diversification factor was strongest in Hong Kong ( 24 percent), although new products account for 11 to 13 percent of Singapore, Malaysia and Thailand's current exports. An analysis of the underlying statistics shows that certain ores and minerals products account for the negative diversification values in non-regional markets. In other words, East Asia became. internationally uncompetitive for products like tin and lead ores and stopped exporting these items.

While the evidence indicates East Asia greatly improved its ability to compete in regional markets, an important question concerns its performance elsewhere. Specifically, could the results for regional markets have been biased by special factors like, for example, geographic proximity. For answers, the previous analysis, which was based on trade in individual four-digit SITC products, was repeated for trade with the European Union (15), NAFTA, and Japan. The results are reported in the lower one-half of Table 9.1.

In all three major markets the East Asian countries registered strong competitive trade gains during both time periods tested. Over 1995-2001, the competitive market share gains were between $\$ 34$ to $\$ 36$ billion in NAFTA and the EU (15). In the latter, the competitive gains exceeded those associated with higher demand by about $\$ 13$ billion. A likely cause of the depressed European demand was prolonged sluggish economic conditions, particularly in Germany. In Japan, both the demand and competitive gains were smaller, averaging about $\$ 13$ billion. Overall the data document the improved ability of East Asian countries to compete in both regional and global markets.

${ }^{14}$ The actual change in total 1985-2001 intra-regional trade exceeded the sum of changes reported for the demand and competitive factors by approximately $\$ 30.8$ billion. As indicated, this value represents the increase in regional trade associated with diversification into new product lines. For useful analyses of the factors responsible for the improvernent in East Asia's competitiveness see Yusuf and Evenett (2002) or Crafts (1998) 
Table 9. 1 The Impact of Competition and Demand Changes on East Asian Intra-Regional Trade

\begin{tabular}{|c|c|c|c|c|c|c|c|c|c|}
\hline \multirow[b]{2}{*}{ Trader } & \multicolumn{3}{|c|}{ Exports $(\$ 000)$} & \multicolumn{3}{|c|}{$\begin{array}{l}\text { Factors Underlying the 1995-2001 Export Change } \\
\text { (\$ million)* }\end{array}$} & \multicolumn{3}{|c|}{$\begin{array}{l}\text { Factors Underlying the 1985-2001 Export Change } \\
\qquad(\$ \text { million })^{*}\end{array}$} \\
\hline & 1985 & 1995 & 2001 & $\begin{array}{l}\text { Demand } \\
\text { Factor }\end{array}$ & $\begin{array}{l}\text { Competitive } \\
\text { Factor }\end{array}$ & Diversification & $\begin{array}{c}\text { Demand } \\
\text { Factor }\end{array}$ & $\begin{array}{l}\text { Competitive } \\
\text { Factor }\end{array}$ & Diversification \\
\hline REGIONAL TRADE & & & & & & & & & \\
\hline Brunei Darussalam & 922 & 951 & 1,192 & 923 & -650 & -32 & 2,073 & $-1,796$ & -7 \\
\hline Cambodia & 3 & 276 & 182 & -10 & -85 & 1 & 2 & 150 & 27 \\
\hline China & 10,867 & 90,799 & 127,796 & 2,856 & 30,796 & 3,345 & 43,052 & 69,649 & 4,228 \\
\hline Hong Kong & 6,637 & 20,016 & 20,981 & 3,601 & $-3,419$ & 783 & 38,480 & $-29,183$ & 5,047 \\
\hline Indonesia & 1,953 & 12,008 & 17,155 & 2,575 & 2,093 & 479 & 4,516 & 9,473 & 1,213 \\
\hline Korea & 2,559 & 40,346 & 55,748 & 2,243 & 10,441 & 2,718 & 13,070 & 36,365 & 3,754 \\
\hline Lao P.D. Republic & 17 & 190 & 220 & -7 & 4 & 33 & 18 & 71 & 114 \\
\hline Malaysia & 6,844 & 37,642 & 46,759 & 8,087 & 1,105 & -75 & 23,367 & 11,417 & 5,131 \\
\hline Mongolia & 4 & 111 & 242 & 22 & 111 & -2 & 53 & 185 & 0 \\
\hline Philippines & 1,071 & 4,645 & 14,736 & 1,930 & 8,157 & 4 & 12,979 & 536 & 150 \\
\hline Singapore & 6,032 & 38,979 & 41,806 & 9,209 & $-6,629$ & 249 & 25,678 & 5,594 & 4,502 \\
\hline Taiwan, China & 4,994 & 49,069 & 62,477 & 3,930 & 5,965 & 3,513 & 28,293 & 25,918 & 3,272 \\
\hline Thailand & 1,982 & 17,548 & 24,359 & 3,398 & 1,694 & 1,719 & 9,172 & 10,156 & 3,049 \\
\hline Vietnam & 182 & 1,916 & 4,354 & 60 & 2,218 & 160 & 484 & 3,396 & 292 \\
\hline All Above Countries & 44,067 & 314,496 & 418,007 & 38,817 & 51,801 & 12,893 & 201,237 & 141,931 & 30,772 \\
\hline \multicolumn{10}{|l|}{$\begin{array}{l}\text { NON-REGIONAL } \\
\text { TRADE }\end{array}$} \\
\hline East Asia - Japan & 35,280 & 118,717 & 144,884 & 13,419 & 12,743 & 5 & 64,707 & 45,289 & -392 \\
\hline East Asia-NAFTA & 61,368 & 196,118 & 309,066 & 79,093 & 34,373 & -518 & 155,262 & 92,136 & 300 \\
\hline East Asia - EU (15) & 22,352 & 124,015 & 182,182 & 23,049 & 35,808 & -690 & 61,232 & 97,759 & 839 \\
\hline
\end{tabular}

* The demand factor isolates the effects of the increase or decrease in regional demand for other East Asian countries' exports. This factor shows the increase or decrease in exports that would have occurred had there been no change in the country's market shares from the 1990 or 1995 base period. The competitive factor shows the change in exports, over or under that associated with demand changes, due to changes in a country's import market shares. Any difference between the change in the total exports and the sum of these two factors is due to product diversification.

Source: Computations based on UN COMTRADE statistics. 


\section{Trade Trends 10 \\ Who Lost in East Asian Markets!!!}

\section{$\underline{\text { Key Point }}$}

East Asian exporters made broad based competitive gains in local markets against all major nonregional suppliers during 1985-2001. On average, East Asia increased its regional import share by about 18 percentage points for the 30 largeit products in intra-trade (which implies trade gains of approximately $\$ 78$ billion). NAFTA and Japan experienced the largest competitive losses in East Asian markets as their import shares fell by seven to eight percentage points, respectively.

Trade Trends 9 showed that competitive gains often were responsible for significant increases in East Asian countries intra-trade, but the underlying disaggregate statistics revealed instances where regional trade shares appeared to static (as in the case of some textile and clothing products), or even declined in the case of energy products. This raises the question as to whether any non-regional countries, or groups of countries, expanded their share of regional imports. Conversely, what non-regional countries suffered the greatest displacement due to competitive gains made by East Asian exporters. For example, were (say) NAFTA or the European Union's regional import shares eroded to the same degree, or were there important differences in how they fared against East Asian competitors.

Table 10.1 provides information on East Asian 1985-2001 market share changes for six major countries or country groups, namely, NAFTA, the European Union (15), all countries in Latin America and the Caribbean, South Asia, Japan, and Australia and New Zealand combined. These import share changes are reported for the 30 largest four-digit products East Asian countries export to the region. Altogether, these items account for just over one-half of total intra-regional trade (see Trade Trends 12 which follows). To assist in the evaluation of this information the table also shows regional market share changes for the East Asian countries combined.

Three significant points emerge from these statistics. First, the East Asian countries made broad based competitive gains against all of the major non-regional suppliers. On average, East Asia increased its regional import share by about 18 percent (which implies annual trade gains of approximately $\$ 78$ billion). In six of the thirty product groups, East Asian regional import shares increase by more than fifty percentage points (the product descriptions of these items are highlighted in boldface), while in thirteen of the groups the increase exceeded twenty five percentage points. The only exception to the general pattern of increases occurs for the two energy products where regional market shares declined.

Second, the NAFTA countries saw the greatest erosion of their regional import shares which fell by an average of about 8 percentage points. This implies annual trade losses of about $\$ 36$ billion. The relatively strong US dollar, particularly in the last half of the 1990's, almost certainly was a contributory factor. NAFTA countries may also have diverted some exports from Asia to North America in order to capitalize on the newly established p:eferential tariffs. The average market share for Japanese exports fell by 7.4 points on average. However, four products, namely, radiotelephonic equipment, telephonic electrical line, sound recorders, and copper alloys had their market shares reduced by more than 30 percentage points.

Third, the most important East Asian competitive share trade gains occurred within the broad machinery and transport equipment (SITC 7) group. Market share increases for seven four-digit SITC office machinery and equipment (SITC 77) products generated increased annual earnings of about \$26 billion, while competitive gains for four telecommunications equipment (SITC 76) products increased export earnings by approximately $\$ 18$ billion. East Asia virtually eliminated regional competition for digital control storage units (SITC 752.4) and radiotelephonic and radiotelegraphic equipment (SITC 764.3) where their market shares rose by more than 60 percentage points. 
Table 10.1 1985-2001 Major Product Competitive Change Effects for Non-Regional Countries in East Asian Markets.

\begin{tabular}{|c|c|c|c|c|c|c|c|c|}
\hline \multirow[b]{2}{*}{ Major Export Product (SITC)* } & \multirow{2}{*}{$\begin{array}{c}2001 \text { East Asian } \\
\text { Global Imports } \\
(\$ \text { million })\end{array}$} & \multicolumn{7}{|c|}{ 1985-2001 East Asian Market Share Changes (percentage points) } \\
\hline & & $\begin{array}{l}\text { East } \\
\text { Asia }\end{array}$ & NAFTA & EU(15) & LAC & $\begin{array}{c}\text { South } \\
\text { Asia }\end{array}$ & Japan & $\begin{array}{c}\text { Australia/ } \\
\text { New Zealand }\end{array}$ \\
\hline Electronic microcircuits (776.4) & 89,707 & 14.0 & -3.6 & 3.3 & 0.4 & -0.1 & -13.0 & 0.0 \\
\hline Parts of office machinery (759.9) & 37,547 & 36.8 & -35.7 & -1.1 & 1.4 & -0.2 & -4.2 & -0.2 \\
\hline Parts of telecommunications equipment (764.9) & 23,658 & 20.7 & -3.1 & 3.3 & 0.3 & 0.0 & -25.6 & 0.2 \\
\hline Radiotelegraphic and telephonic equipment (764.3) & 13,047 & 61.2 & -25.0 & 6.1 & 0.0 & 0.0 & -44.8 & 0.0 \\
\hline Digital central storage units $(\mathbf{7 5 2 . 4 )}$ & 11,786 & 68.7 & -32.5 & -1.1 & -17.1 & 0.1 & -22.1 & 0.0 \\
\hline Petroleum oils (333.0) & 60,469 & -21.0 & -0.1 & 0.2 & -3.5 & -0.2 & 0.0 & 2.5 \\
\hline Diodes and transistors (776.3) & 11,984 & 23.5 & -16.8 & -8.6 & 0.3 & 0.1 & -1.4 & 0.0 \\
\hline Children's toy and games (894.2) & 7,010 & 19.1 & -5.3 & -3.3 & 0.0 & 0.0 & -9.6 & -0.1 \\
\hline Other electrical machinery $(778.8)$ & 14,509 & 22.7 & -3.8 & -6.2 & 0.6 & -0.2 & -15.9 & 0.0 \\
\hline Piezo-electric crystals (776.8) & 25,111 & 9.6 & -24.6 & 6.6 & 0.3 & 0.0 & 4.2 & 0.0 \\
\hline Electronic Peripheral control units (752.5) & 7,694 & 60.1 & -36.8 & -7.1 & -3.2 & -0.5 & -14.5 & -0.9 \\
\hline Footwear $(851.0)$ & 5,613 & 34.0 & -1.1 & -20.7 & 0.0 & 0.0 & -7.2 & 0.0 \\
\hline Other electrical power machinery (771.2) & 7,584 & 29.3 & -8.0 & -0.8 & -0.4 & 0.5 & -23.7 & 0.2 \\
\hline Electrical switches and relays $(772.1)$ & 14,148 & 19.7 & -8.7 & 0.0 & 0.3 & 0.0 & -11.4 & -0.2 \\
\hline Printed circuits and parts thereof (772.2) & 6,738 & 39.4 & -42.0 & -4.5 & 0.4 & 0.0 & 4.3 & -0.1 \\
\hline Jerseys and pullovers ( 845.1 ) & 4,420 & 4.8 & -0.1 & -4.1 & 0.1 & 0.9 & -2.1 & 0.6 \\
\hline Polystyrene (583.3) & 5,104 & 62.1 & -8.5 & -14.5 & -3.1 & 0.3 & -6.1 & -1.1 \\
\hline Petroleum gases (341.3) & 8,509 & 16.4 & 0.4 & 0.3 & 0.0 & 0.0 & 0.1 & -1.9 \\
\hline Knitted fabrics (655.2) & 4,577 & 5.1 & 0.9 & 0.4 & 0.0 & 0.2 & -10.3 & 0.2 \\
\hline Woven fabrics (653.1) & 4,482 & 17.5 & -0.5 & 0.0 & 0.0 & 0.4 & -18.4 & 0.0 \\
\hline Miscellaneous art materials (893.9) & 6,221 & 16.1 & -3.3 & -7.5 & 0.2 & 0.1 & -4.8 & -0.3 \\
\hline Travel goods and handbags $(831.0)$ & 4,093 & 7.0 & -0.3 & -2.8 & 0.0 & -0.2 & -3.8 & -0.1 \\
\hline Electric motors and generators (716.2) & 5,135 & 53.6 & -25.4 & -3.7 & 0.0 & 0.0 & -30.4 & 0.2 \\
\hline Specialized machinery and appliances (728.4) & 18,808 & 6.3 & -3.2 & -3.3 & 0.0 & 0.1 & 0.0 & -0.1 \\
\hline Woven cotton fabrics $(652.2)$ & 4,266 & 17.4 & -1.2 & -0.4 & 0.0 & -0.8 & -19.6 & 0.0 \\
\hline Insulated electrical wire and cable (773.1) & 4,854 & 41.1 & -4.5 & -12.3 & 0.2 & 0.0 & -27.9 & 0.5 \\
\hline Telephonic electrical line (764.1) & 8,689 & 27.3 & 20.3 & -12.4 & 1.1 & 0.0 & -36.8 & -0.1 \\
\hline Other sound recorders (763.8) & 4,323 & 55.6 & 0.2 & 0.3 & 0.1 & 0.0 & -38.7 & 0.0 \\
\hline Copper and copper alloys $(682.2)$ & 4,792 & 34.1 & -3.1 & -4.2 & -0.6 & 0.1 & -30.4 & 0.1 \\
\hline Gas oils (334.3) & 3,395 & -16.9 & -3.7 & 0.1 & 0.0 & 0.0 & 3.8 & -0.4 \\
\hline ALL ABOVE PRODUCTS & 428,272 & 18.1 & -8.5 & -1.7 & -0.8 & -- & -7.4 & -- \\
\hline
\end{tabular}

East Asian import market shares rose by 50 percentage points or more for products whose description are highlighted in boldface. To be included in this list a product had to be among the 30 largest four-digit SITC items in intra-regional trade.

Source: Computations based on UN COMTRADE statistics. 
Table 10.2 1995-2001 Major Product Competitive Change Effects for Non-Regional Countries in East Asian Markets.

\begin{tabular}{|c|c|c|c|c|c|c|c|c|}
\hline \multirow[b]{2}{*}{ Major Export Product (SITC)* } & \multirow{2}{*}{$\begin{array}{c}2001 \text { East Asian } \\
\text { Global Imports } \\
\text { (\$million) }\end{array}$} & \multicolumn{7}{|c|}{ 1995-2001 East Asian Market Share Changes (percentage points) } \\
\hline & & $\begin{array}{l}\text { East } \\
\text { Asia }\end{array}$ & NAFTA & $\mathrm{EU}(15)$ & LAC & $\begin{array}{c}\text { South } \\
\text { Asia }\end{array}$ & Japan & $\begin{array}{c}\text { Australia/ } \\
\text { New Zealand }\end{array}$ \\
\hline Electronic microcircuits (776.4) & 89,707 & 10.9 & -3.8 & 1.0 & 0.5 & 0.0 & -10.2 & 0.0 \\
\hline Parts of office machinery (759.9) & 37,547 & 5.1 & -7.4 & 0.0 & 1.4 & 0.7 & -2.7 & -0.5 \\
\hline Parts of telecommunications equipment (764.9) & 23,658 & -3.0 & 1.0 & 8.1 & 0.2 & 0.0 & -9.8 & 0.1 \\
\hline Radiotelegraphic and telephonic equipment (764.3) & 13,047 & 44.2 & -31.9 & -11.8 & 0.0 & 0.0 & -1.7 & -0.4 \\
\hline Digital central storage units (752.4) & 11,786 & 7.5 & -4.2 & 1.2 & 0.3 & 0.1 & -8.3 & -0.2 \\
\hline Petroleum oils (333.0) & 60,469 & -5.8 & 0.1 & 0.1 & -0.4 & 0.2 & 0.0 & 2.1 \\
\hline Diodes and transistors (776.3) & 11,984 & 9.0 & -0.1 & -1.9 & -0.2 & 0.1 & -10.3 & 0.0 \\
\hline Children's toy and games (894.2) & 7,010 & 7.3 & -6.2 & -1.1 & 0.0 & -0.1 & -0.9 & 0.3 \\
\hline Other electrical machinery (778.8) & 14,509 & 6.7 & -0.7 & -0.9 & 0.5 & 0.0 & -7.6 & 0.0 \\
\hline Piezo-electric crystals (776.8) & 25,111 & 7.8 & -2.9 & 4.0 & 0.2 & 0.0 & -12.5 & 0.0 \\
\hline Electronic Peripheral control units (752.5) & 7,694 & 28.9 & -14.6 & -6.4 & -0.1 & -0.1 & -10.4 & -0.7 \\
\hline Footwear $(851.0)$ & 5,613 & 1.2 & -0.4 & -0.8 & 0.2 & 0.0 & -0.5 & 0.0 \\
\hline Other electrical power machinery $(771.2)$ & 7,584 & 5.9 & -0.4 & 1.0 & 0.0 & 0.2 & -9.7 & -0.2 \\
\hline Electrical switches and relays $(772.1)$ & 14,148 & 6.5 & 0.4 & -0.7 & 0.3 & 0.0 & -7.5 & -0.2 \\
\hline Printed circuits and parts thereof $(772.2)$ & 6,738 & 4.0 & -3.6 & 1.4 & 0.3 & 0.0 & -4.4 & 0.0 \\
\hline Jerseys and pullovers (845.1) & 4,420 & 2.1 & -0.1 & -2.4 & 0.1 & 0.6 & 0.0 & 0.5 \\
\hline Polystyrene (583.3) & 5,104 & 18.7 & -6.6 & -2.3 & -0.1 & 0.3 & -10.2 & -0.2 \\
\hline Petroleum gases (341.3) & 8,509 & -11.7 & -0.2 & 0.2 & 0.0 & 0.0 & 0.0 & 1.5 \\
\hline Knitted fabrics (655.2) & 4,577 & -1.2 & 0.5 & 0.9 & 0.0 & 0.0 & -1.9 & 0.1 \\
\hline Woven fabrics $(653.1)$ & 4,482 & -5.5 & 0.1 & 0.3 & 0.0 & 0.2 & 4.1 & 0.0 \\
\hline Miscellaneous art materials (893.9) & 6,221 & -0.4 & 0.7 & -0.3 & 0.1 & 0.0 & -0.2 & -0.2 \\
\hline Travel goods and handbags (831.0) & 4,093 & -0.5 & -0.1 & 0.3 & 0.0 & 0.1 & -0.1 & 0.0 \\
\hline Electric motors and generators (716.2) & 5,135 & 20.2 & -8.7 & -4.5 & 0.0 & 0.0 & -12.8 & -0.1 \\
\hline Specialized machinery and appliances (728.4) & 18,808 & 2.9 & 1.5 & -5.7 & 0.0 & 0.1 & 1.0 & -0.2 \\
\hline Woven cotton fabrics $(652.2)$ & 4,266 & $-3: 3$ & -1.5 & 0.5 & 0.0 & -0.6 & 5.0 & 0.0 \\
\hline Insulated electrical wire and cable (773.1) & 4,854 & 9.5 & -2.4 & -3.0 & 0.1 & 0.0 & -6.0 & 0.3 \\
\hline Telephonic electrical line (764.1) & 8,689 & 3.3 & 15.7 & -8.7 & 1.1 & 0.0 & -11.1 & -1.1 \\
\hline Other sound recorders $(763.8)$ & 4,323 & 6.5 & 0.4 & 0.2 & 0.0 & 0.0 & -8.3 & 0.0 \\
\hline Copper and copper alloys (682.2) & 4,792 & 11.1 & -2.8 & 1.0 & -0.3 & 0.1 & -9.7 & -2.0 \\
\hline Gas oils (334.3) & 3,395 & 2.1 & -5.6 & -1.9 & -0.2 & 0.0 & -3.4 & -0.1 \\
\hline ALL ABOVE PRODUCTS & 428,272 & 4.2 & -2.4 & -1.0 & 0.3 & 0.1 & -7.1 & 0.2 \\
\hline
\end{tabular}

Source: Computations based on UN COMTRADE statistics. 
Finally, a question of interest concerns the pattern of market share changes during the 1995-2001 period that covers the Asian financial crisis. As indicated in Table 10.2, East Asian countries generally continued to improve their competitive position with their average market share increasing by just over 4 percentage points. $^{15}$ However, what is different from the full 1985-2001 period is the fact that East Asian exporters market shares declined for 8 of the 30 products. Aside from energy products, the eroded shares appear to be concentrated in products that are often manufactured using labor intensive production processes, that is, items like travel goods, and knit or woven fabrics.

Trade Trends 11

Changes in the Product Composition of East Asian Intra-Trade

\section{$\underline{\text { Key Point }}$}

Since 1985 the product composition of East Asian intra-trade changed dramatically as the share of machinery and transport equipment rose by over 26 percentage points. At present, these goods account for almost one half of all goods traded within the region. A similar pattern is observed in non-regional trade as the share of machinery and transport equipment rose from 18 to 46 percent from 1985 to 2001 . In both regional and non-regional markets, mineral fuels and crude materials exports registered the largest decline in relative importance.

Several important policy questions relate to the broad product composition of individual East Asian country's regional exports. Are the export profiles basically similar, or do important differences exist. Differences in the composition of exports could be a positive factor if it allowed the exploitation of trade based on comparative advantage. However, it should be noted that countries that previously formed "successful" regional trade arrangements, like the European Union, imilar export profiles. ${ }^{16}$ This may be due, in part, to the importance of opportunities to exploit intra-industry trade, or to engage in mutually beneficial production sharing. Second, does the evidence indicate that most East Asian export profiles are static, or are important changes taking place. If the export profiles are changing, are they evolving in similar, or dissimilar, directions? Third, it has long been recognized that primary commodities, and most other raw materials, have unfavorable long-term trade prospects. If some East Asian countries' exports contain a relatively high share of these goods this could have negative implications for longer-term trade prospects. $^{17}$

\footnotetext{
${ }^{15}$ If one sums the positive and negative market share changes for the "all products group" in Table 10.2 the latter exceeds the positive changes by almost 5 percentage points. This difference is largely accounted for by market share gains made by energy exporters in Africa and the Middle East. These regions have not been included in the table.

${ }^{16}$ At the time of the original EU (6) formation the share of manufactured goods in member countries' exports ranged from highs of nearly 80 percent for Italy and Germany to the mid-50s for the Netherlands. Similarly, the corresponding shares for the original EFTA countries averaged well over 60 percent. The share of manufactures in Canada's exports was about 60 percent, as opposed to a corresponding share of 75 percent for the United States, when negotiations on the Canadian-American Free Trade Agreement were concluded.

${ }^{17}$ This proposition traces it origins to the writing of Raul Prebisch, former chairman of the UN Economic Commission for Latin America and Hans Singer of the United Nations. A major contributing factor to the adverse long term prospects for primary commodities is the low income elasticity of demand for many of these items. Hogendorn (1987, chapter 12) provides a useful survey of the relevant issues. Recent evidence (Ng and Yeats, 2002) shows an extensive deterioration in the terms-of-trade for commodities occurred over the last two decades, and this is projected to continue into the foreseeable future.
} 
Table 11.1 provides summary statistics on the composition of each East Asian country's regional exports in 1985, 1995 and 2001 by showing the share of trade accounted for by broad product groups like foodstuffs, agricultural raw materials, ores and metals, or manufactures. In addition, the table provides similar trade statistics for all regional countries combined. The question as to whether export opportunities within the region differ substantially from those found elsewhere is also considered. For answers, the table's "memo item" shows the shares of these product groups in total exports to all non-regional markets.

Perhaps the most striking point to emerge from Table 11.1 concerns the major increase in the relative importance of machinery and transportation equipment in intra-trade. These goods share in Malaysian and Thailand's exports rose more than four-fold since the mid-1980s, while their export share for China, the Philippines, Singapore, and Thailand rose by 30 percentage points or more. ${ }^{18}$ Significant increases in the share of machinery and transport equipment occurred for almost all of the East Asian countries, with the exceptions of Brunei, Laos, and Mongolia. At the opposite extreme, the importance of mineral fuels registered the largest relative decline. In 1985, fuels accounted for about one-fifth of East Asian intra-trade as opposed about 7 percent today.

Which countries regional exports differ significantly from the East Asian average? In terms of manufactured goods (that is, the combined trade of chemicals, transport and machinery, and the "other" manufactures group) Brunei, Lao PDR, and Mongolia exports contain less than one-half the average share of these goods in all East Asian regional exports. Brunei's exports are concentrated in mineral fuels whose export share ( 82.5 percent) is more than 20 times higher than the regional average. Similarly, Lao PDR exports are highly concentrated in agricultural raw materials ( 85 percent of total exports) while Mongolia's exports, which largely consist of copper ores, have an abnormally high concentration (77 percent) in ores, minerals and metals. Appendix Table A4 identifies the largest four-digit regional products exported by each East Asian country.

As far as these product grcups are concerned, the changes in the composition of East Asia's exports to regional markets closely parallels that in trade with other countries. The overall share of machinery and transport equipment in regional exports increased by about 27 percentage points (from 21 to 47.9 percent), which was one percentage point less than the increase in non-regional markets (see the memo item). Furthermore, in both regional and non-regional trade mineral fuels experienced the greatest relative decline in importance, followed by foodstuffs and agricultural raw materials.

Table 11.2 examines the regional countries' export profiles from a somewhat different perspective. Shown here are the total values of East Asian exports in 1985, 1995 and 2001 to; (i) other regional countries, (ii) Japan, and (iii) all other countries combined. The lower portion of the table shows the share of these exports accounted for by each one-digit SITC product group. These data reveal strong similarities in the composition of exports to these different destinations. In each case, the rank order of the three largest product groups is the same, that is, machinery and transport equipment, followed by miscellaneous manufactures, and manufactures classified by material. ${ }^{19}$ In addition, these three categories of goods account for about 70 percent, or more, of the total exports to each destination. Table 11.2 also reveals strong similarities in trade trends. In each case, exports of machinery and transport equipment registered the largest 1985-2001 trades share increase, while mineral fuels and crude materials experienced the largest relative declines.

\footnotetext{
${ }^{18}$ The rapid expansion of Chinese and several other East Asian countries exports of these products was made possible by participation in the international segmentation of production processes. China specializes in assembling imported parts and components. According to Lemoine and Unal-Kesenci (2002) in 199985 percent of China's exports of electrical machinery, and 80 percent of its exports of precision instruments were the result of international assembly operations.

${ }^{19}$ Trade Trends 12 provides additional information on the largest four-digit SITC products East Asia exports to these three destinations. Even at these relatively low levels of detail strong similarities exist in the composition of exports.
} 
Table 11.1 The Export Structure of East Asian Intra-Trade by Major Product Categories: 1985, 1995 and 2001

\begin{tabular}{|c|c|c|c|c|c|c|c|c|c|c|}
\hline \multirow[b]{2}{*}{ Exporter } & \multirow[b]{2}{*}{ Year } & \multirow{2}{*}{$\begin{array}{l}\text { Exports to } \\
\text { East Asia } \\
\text { (\$million) }\end{array}$} & \multicolumn{8}{|c|}{ Share of Product Group in Total Exports to East Asia (\%) } \\
\hline & & & $\begin{array}{l}\text { Foods and } \\
\text { Feeds }\end{array}$ & $\begin{array}{c}\text { Agricultural } \\
\text { Materials }\end{array}$ & $\begin{array}{c}\text { Mineral } \\
\text { Fuels } \\
\end{array}$ & $\begin{array}{c}\text { Ores, Minerals } \\
\text { \& Metals }\end{array}$ & Chemicals & $\begin{array}{l}\text { Machinery } \\
\text { \& Transport }\end{array}$ & $\begin{array}{c}\text { Other } \\
\text { Manufactures } \\
\end{array}$ & $\begin{array}{l}\text { Misc. } \\
\text { Goods }\end{array}$ \\
\hline \multirow[t]{3}{*}{ Brunei } & 1985 & 921 & 0.1 & 0.1 & 98.3 & 0.1 & 0.2 & 0.4 & 0.1 & 0.5 \\
\hline & 1995 & 952 & 0.1 & 0.1 & 93.0 & 0.4 & 0.0 & 1.3 & 3.6 & 0.5 \\
\hline & 2001 & 1,213 & 0.1 & 0.1 & 82.5 & 0.3 & 0.0 & 3.5 & 12.3 & 0.5 \\
\hline \multirow[t]{3}{*}{ Cambodia } & 1985 & 2 & 18.7 & 47.2 & 0.0 & 0.0 & 0.3 & 0.0 & 0.0 & 0.1 \\
\hline & 1995 & 249 & 3.9 & 88.4 & 0.0 & 0.2 & 0.3 & 0.7 & 5.9 & 0.2 \\
\hline & 2001 & 154 & 9.1 & 21.2 & 0.0 & 2.1 . & 0.2 & 6.6 & 49.5 & 1.3 \\
\hline \multirow[t]{3}{*}{ China } & 1985 & 10,818 & 15.1 & 5.0 & 21.6 & 2.2 & 4.0 & 5.6 & 33.8 & 10.9 \\
\hline & 1995 & 90,243 & 4.0 & 1.5 & 2.2 & 6.1 & 3.8 & 25.8 & 28.3 & 27.1 \\
\hline & 2001 & 124,283 & 3.4 & 0.6 & 3.2 & 3.2 & 3.1 & 37.9 & 25.3 & 22.6 \\
\hline \multirow[t]{3}{*}{ Hong Kong } & 1985 & 10,279 & 2.1 & 1.5 & 1.0 & 1.3 & 3.6 & 39.5 & 34.0 & 15.3 \\
\hline & 1995 & 19,460 & 3.2 & 1.3 & 0.6 & 2.7 & 5.2 & 45.9 & 24.2 & 14.2 \\
\hline & 2001 & 19,597 & 1.6 & 0.6 & 0.9 & 3.5 & 6.4 & 49.7 & 21.8 & 13.0 \\
\hline \multirow[t]{3}{*}{ Indonesia } & 1985 & 2,221 & 7.6 & 13.4 & 44.4 & 2.0 & 5.6 & 1.0 & 25.2 & 0.2 \\
\hline & 1995 & 11,673 & 4.2 & 8.8 & 31.8 & 6.7 & 8.2 & 4.4 & 28.5 & 2.5 \\
\hline & 2001 & 16,812 & 4.1 & 10.8 & 32.1 & 6.6 & 9.5 & 14.0 & 16.7 & 1.8 \\
\hline \multirow[t]{3}{*}{ Korea } & 1985 & 2,573 & 2.1 & 2.4 & 3.6 & 11.8 & 12.5 & 28.3 & 30.0 & 6.2 \\
\hline & 1995 & 39,707 & 1.1 & 2.2 & 2.5 & 8.1 & 14.5 & 39.5 & 25.0 & 3.4 \\
\hline & 2001 & 52,511 & 0.6 & 1.5 & 7.1 & 8.8 & 16.0 & 45.9 & 16.1 & 3.3 \\
\hline \multirow[t]{3}{*}{ Laos } & 1985 & 14 & 12.9 & 83.2 & 0.0 & 0.9 & 0.0 & 1.5 & 0.7 & 0.4 \\
\hline & 1995 & 106 & 7.9 & 76.4 & 0.2 & 2.9 & 3.8 & 0.4 & 4.1 & 0.8 \\
\hline & 2001 & 102 & 2.1 & 77.4 & 1.7 & 5.1 & 0.2 & 2.8 & 3.1 & 0.7 \\
\hline \multirow[t]{3}{*}{ Malaysia } & 1985 & 6,939 & 15.5 & 20.8 & 37.5 & 1.3 & 1.3 & 15.5 & 5.8 & 1.3 \\
\hline & 1995 & 35,159 & 7.6 & 7.3 & 7.7 & 2.8 & 3.9 & 53.7 & 10.5 & 5.3 \\
\hline & 2001 & 44,724 & 4.3 & 2.3 & 9.4 & 2.0 & 5.3 & 64.5 & 7.0 & 4.5 \\
\hline \multirow[t]{3}{*}{ Mongolia } & 1985 & 5 & 0.0 & 83.1 & 0.0 & 2.5 & 0.0 & 0.0 & 13.7 & 0.7 \\
\hline & 1995 & 109 & 3.4 & 39.5 & 0.0 & 55.2 & 0.7 & 0.1 & 1.1 & 0.1 \\
\hline & 2001 & 243 & 1.0 & 7.7 & 0.7 & 77.6 & 0.0 & 0.1 & 13.1 & 0.0 \\
\hline
\end{tabular}


Table11.1. Continued

\begin{tabular}{|c|c|c|c|c|c|c|c|c|c|c|}
\hline \multirow[b]{2}{*}{ Exporter } & \multirow[b]{2}{*}{ Year } & \multirow{2}{*}{$\begin{array}{l}\text { Exports to } \\
\text { East Asia } \\
\text { (\$million.) }\end{array}$} & \multicolumn{8}{|c|}{ Share of Product Group in Total Exports to East Asia (\%) } \\
\hline & & & $\begin{array}{l}\text { Foods and } \\
\text { Feeds }\end{array}$ & $\begin{array}{l}\text { Agricultural } \\
\text { Materials }\end{array}$ & $\begin{array}{l}\text { Mineral } \\
\text { Fuels }\end{array}$ & $\begin{array}{c}\text { Ores, Minerals } \\
\& \text { Metals }\end{array}$ & Chemicals & $\begin{array}{l}\text { Machinery } \\
\text { \& Transport }\end{array}$ & $\begin{array}{c}\text { Other } \\
\text { Manufactures }\end{array}$ & $\begin{array}{l}\text { Misc. } \\
\text { Goods }\end{array}$ \\
\hline Philippines & $\begin{array}{l}1985 \\
1995 \\
2001\end{array}$ & $\begin{array}{c}1,120 \\
4,596 \\
14,727\end{array}$ & $\begin{array}{l}12.7 \\
8.8 \\
3.0\end{array}$ & $\begin{array}{l}3.9 \\
1.8 \\
0.3\end{array}$ & $\begin{array}{c}10.1 \\
3.6 \\
1.3\end{array}$ & $\begin{array}{l}10.0 \\
11.1 \\
3.0\end{array}$ & $\begin{array}{l}11.4 \\
3.0 \\
1.6\end{array}$ & $\begin{array}{l}40.1 \\
60.8 \\
84.1\end{array}$ & $\begin{array}{l}6.4 \\
4.4 \\
2.2\end{array}$ & $\begin{array}{l}2.1 \\
3.5 \\
2.3\end{array}$ \\
\hline Singapore & $\begin{array}{l}1985 \\
1995 \\
2001\end{array}$ & $\begin{array}{c}6,273 \\
36,403 \\
38,076\end{array}$ & $\begin{array}{l}2.5 \\
1.8 \\
1.1\end{array}$ & $\begin{array}{l}1.5 \\
0.6 \\
0.3\end{array}$ & $\begin{array}{l}46.7 \\
20.9 \\
15.6\end{array}$ & $\begin{array}{l}2.6 \\
2.4 \\
1.5\end{array}$ & $\begin{array}{c}9.4 \\
8.2 \\
11.7\end{array}$ & $\begin{array}{l}25.5 \\
53.7 \\
59.3\end{array}$ & $\begin{array}{l}4.3 \\
4.0 \\
3.5\end{array}$ & $\begin{array}{l}3.4 \\
4.8 \\
5.3\end{array}$ \\
\hline Taiwan, China & $\begin{array}{l}1985 \\
1995 \\
2001\end{array}$ & $\begin{array}{c}5,525 \\
49,927 \\
59,992\end{array}$ & $\begin{array}{l}3.6 \\
1.1 \\
0.7\end{array}$ & $\begin{array}{l}3.7 \\
2.2 \\
1.3\end{array}$ & $\begin{array}{l}2.6 \\
0.4 \\
1.1\end{array}$ & $\begin{array}{l}7.0 \\
6.1 \\
8.3\end{array}$ & $\begin{array}{c}7.1 \\
14.9 \\
13.8\end{array}$ & $\begin{array}{l}26.9 \\
41.0 \\
53.3\end{array}$ & $\begin{array}{l}36.7 \\
26.7 \\
15.9\end{array}$ & $\begin{array}{l}9.7 \\
6.5 \\
5.3\end{array}$ \\
\hline Thailand & $\begin{array}{l}1985 \\
1995 \\
2001\end{array}$ & $\begin{array}{c}2,091 \\
16,396 \\
22,020\end{array}$ & $\begin{array}{l}50.6 \\
17.1 \\
10.5\end{array}$ & $\begin{array}{l}11.5 \\
5.7 \\
5.4\end{array}$ & $\begin{array}{l}0.4 \\
1.0 \\
5.7\end{array}$ & $\begin{array}{l}5.3 \\
2.4 \\
2.9\end{array}$ & $\begin{array}{c}4.0 \\
6.0 \\
11.7\end{array}$ & $\begin{array}{l}12.2 \\
49.6 \\
50.1\end{array}$ & $\begin{array}{l}11.8 \\
11.9 \\
9.2\end{array}$ & $\begin{array}{l}3.0 \\
4.8 \\
3.2\end{array}$ \\
\hline Vietnam & $\begin{array}{l}1985 \\
1995 \\
2001\end{array}$ & $\begin{array}{c}183 \\
1,787 \\
4,062\end{array}$ & $\begin{array}{l}77.6 \\
43.8 \\
17.3\end{array}$ & $\begin{array}{c}16.0 \\
10.5 \\
3.6\end{array}$ & $\begin{array}{c}0.3 \\
18.1 \\
42.4\end{array}$ & $\begin{array}{l}2.3 \\
2.8 \\
1.6\end{array}$ & $\begin{array}{l}0.5 \\
1.6 \\
2.6\end{array}$ & $\begin{array}{c}0.1 \\
3.8 \\
15.2\end{array}$ & $\begin{array}{l}1.1 \\
11.8 \\
10.4\end{array}$ & $\begin{array}{l}0.1 \\
5.6 \\
5.7\end{array}$ \\
\hline $\begin{array}{l}\text { All Above } \\
\text { Countries }\end{array}$ & $\begin{array}{l}1985 \\
1995 \\
2001\end{array}$ & $\begin{array}{c}48,965 \\
306,767 \\
398,516\end{array}$ & $\begin{array}{l}9.9 \\
4.2 \\
3.0\end{array}$ & $\begin{array}{l}6.4 \\
2.9 \\
1.7\end{array}$ & $\begin{array}{l}20.9 \\
6.2 \\
7.1\end{array}$ & $\begin{array}{l}3.2 \\
5.2 \\
4.5\end{array}$ & $\begin{array}{l}5.2 \\
7.8 \\
8.3\end{array}$ & $\begin{array}{l}21.0 \\
38.6 \\
47.9\end{array}$ & $\begin{array}{l}23.5 \\
21.0 \\
16.1\end{array}$ & $\begin{array}{c}7.9 \\
12.0 \\
10.3\end{array}$ \\
\hline $\begin{array}{l}\text { MEMO ITEM } \\
\text { East Asian Non- } \\
\text { Regional Exports }\end{array}$ & $\begin{array}{l}1985 \\
1995 \\
2001\end{array}$ & $\begin{array}{l}128,907 \\
501,687 \\
719,116\end{array}$ & $\begin{array}{l}9.2 \\
6.0 \\
3.8\end{array}$ & $\begin{array}{l}4.9 \\
2.5 \\
1.2\end{array}$ & $\begin{array}{l}19.4 \\
4.0 \\
3.8\end{array}$ & $\begin{array}{l}4.1 \\
2.8 \\
3.0\end{array}$ & $\begin{array}{l}2.0 \\
3.1 \\
3.3\end{array}$ & $\begin{array}{l}17.9 \\
40.6 \\
45.9\end{array}$ & $\begin{array}{l}23.4 \\
21.2 \\
19.4\end{array}$ & $\begin{array}{l}15.1 \\
17.6 \\
18.5\end{array}$ \\
\hline
\end{tabular}

Note: The product groups are classified by SITC products in Revision 2 as Foods and Feeds $(0+1+22+4)$; Agricultural raw materials (2-22-27-28); Mineral Fuels (3); Ores And metais (27+28+67+68); Chemicals (5); Machinery and Transport (7); Other Manufactures (6-67-68+84); and Miscellaneous manufactured goods (SITC 8-84).

Source: Computations based on UN COMTRADE statistics. 
Table 11.2 The Composition of East Asian Exports to Regional and Non-Regional Markets in 1985, 1995 and 2001

\begin{tabular}{|c|c|c|c|c|c|c|c|c|c|}
\hline \multirow[b]{2}{*}{ East Asian Exports (SITC No.) } & \multicolumn{3}{|c|}{ East Asia } & \multicolumn{3}{|c|}{ Japan } & \multicolumn{3}{|c|}{ All Other Countries } \\
\hline & 1985 & 1995 & 2001 & 1985 & 1995 & 2001 & 1985 & 1995 & 2001 \\
\hline & \multicolumn{9}{|c|}{ East Asian Exports ( $\$$ million) } \\
\hline ALL GOODS & 48,965 & 306,767 & 398,516 & 35,007 & 118,841 & 145,003 & 99,339 & 382,846 & 574,780 \\
\hline & \multicolumn{9}{|c|}{ Share of East Asian Exports (in \%) } \\
\hline ALL GOODS ( 0 to 9$)$ & 100.0 & 100.0 & 100.0 & 100.0 & 100.0 & 100.0 & 100.0 & 100.0 & 100.0 \\
\hline Food and live animals $(0)$ & 8.6 & 3.4 & 2.7 & 12.1 & 13.1 & 8.8 & 6.3 & 3.3 & 2.6 \\
\hline Beverages and tobacco (1) & 0.5 & 0.5 & 0.3 & 0.1 & 0.1 & 0.1 & 0.3 & 0.1 & 0.1 \\
\hline Crude materials, inedible (2) & 8.1 & 3.7 & 2.4 & 11.4 & 6.6 & 3.6 & 4.5 & 2.5 & 1.4 \\
\hline Mineral fuels and lubricants (3) & 23.0 & 6.2 & 7.1 & 50.9 & 12.9 & 12.6 & 7.4 & 1.2 & 1.6 \\
\hline Animal and vegetable oils (4) & 1.9 & 0.8 & 0.4 & 0.5 & 0.4 & 0.2 & 2.3 & 1.3 & 0.5 \\
\hline Chemicals and related products (5) & 5.0 & 7.8 & 8.3 & 2.4 & 3.1 & 3.6 & 2.0 & 3.1 & 3.2 \\
\hline Manufactured goods (6) & 18.2 & 20.8 & 15.1 & 8.7 & 13.4 & 10.1 & 14.9 & 11.4 & 11.0 \\
\hline Machinery and transport equipment (7) & 18.1 & 38.6 & 47.9 & 3.5 & 24.9 & 35.4 & 24.4 & 45.5 & 48.5 \\
\hline Miscellaneous manufactured articles (8) & 10.6 & 16.7 & 15.2 & 8.6 & 23.8 & 23.4 & 36.6 & 30.4 & 29.8 \\
\hline Commodities and transactions, nes (9) & 5.8 & 1.6 & 0.6 & 1.9 & 1.8 & 2.1 & 1.1 & 1.0 & 1.4 \\
\hline
\end{tabular}

Source: UN COMTRADE Statistics 


\title{
Trade Trends 12 \\ What Products Dominate East Asian Intra-Trade?
}

\author{
$\underline{\text { Key Point }}$
}

East Asian intra-trade is dominated by 30 four-digit SITC products that accounted for just over one half of this exchange in 2001. Within this group, electronic products are of major importance, as are several SITC categories used to record trade in components of various manufactured goods. The latter reflects the rapid expansion in East Asian production sharing operations in which various stages of a manufacturing process are undertaken at different geographic locations. Very strong similarities are observed in the lists of largest products exported to regional and non-regional markets.

There are reasons why countries may want to identify relatively important products in their intratrade, and also determine how the composition of these goods was changing. First, this information could help focus attention on priority seciors for liberalization of government imposed trade barriers in future trade negotiations. Second, if goods that are increasing in importance generally have common characteristics like labor, capital or natural resource intensity in production, this could help focus regional efforts to reduce any transport, or other infra-structure constraints, these types of goods encounter. Third, analyses of intra-trade should attenipt to identify any major potentially "sensitive" products which might adversely affect bilateral trade relations. For example, the Canadian-American Free Trade Agreement (CAFTA) experienced major disputes over issues involving purportedly subsidized Canadian lumber exports.

Given the potential importance of these issues, Table 12.1 reports the value and share of the 30 largest four-digit SITC (Revision 2) products in 2001 intra-regional trade. Similar 1985 statistics for these products are shown, along with 1985-2001 average annual growth rates. The table also identifies the largest exporter and shows its current share of total trade in the good. Appendix Table A4 shows the largest regional export products of each individual East Asian country while Appendix Tables A5 and A6 shows East Asia's largest exports to Japan and all other destinations.

Four important points emerge from these statistics. First, the 30 largest products accounted for just over 50 percent of regional trade in 2001, up sharply from their 35 percent 1985 share. The fact that the SITC system identifies close to 800 individual products at this level (four-digit) of detail accents the relative importance of these thirty items in regional trade. Second, some of the 1985-2001 value and share changes are remarkable! The share of electronic microcircuits rose by over 10 percentage points (to 12.4 percent). Similarly, the share of "parts of office machinery" (SITC 759.9) increased by over 5 percentage points. The fact that 15 of the 30 largest products are classified in SITC groups 75, 76, and 77 (office machinery, telecommunications equipment, and electrical machinery (nes) testifies as to the major importance of electronics in East Asian intra-trade.

Third, a number of the major products are SITC groups that consist solely of parts and components (that is, groups like SITC 759.9 "parts of office machinery", or SITC 764.9 "parts of telecommunications equipment"). "This reflects the rapidly growing importance of international production sharing in East Asia. (see Trade Trends 17 to 19 that follow). Finally, no agricultural products appear in the list. This point, is potentially important since the rural population is normally the most disadvantaged sector of society in developing countries, and a major expansion of agricultural exports could significantly improve living conditions. ${ }^{20}$ A more detailed analysis of intra-trade in agricultural products could provide useful information on this important question.

${ }^{20}$ Available evidence suggests that changes in the structure of East Asian trade barriers could make a significant contribution towards alleviating conditions of rural poverty. Safadi and Yeats (1993) analyzed statistics on tariff escalation in East: Asian countries and concluded this problem was far more serious than in OECD markets. Reduction of tariff escalation in Asia would have a two-fold positive impact on rural 
Table 12.1 raises an interesting question, that is, does the composition of exports to regional markets differ substantially from East Asia's exports to other countries? This might be the case if (say) significant differences occur in regional and non-regional trade barriers, or if transport costs were an important negative constraint to penetration of relatively remote markets in North America or Europe. For answers, Table 12.2 identifies East Asia's 30 largest exports to Japan, and to all other non-regional markets combined (that is, global exports less exports to Japan, less exports to other East Asian countries). To help in assessing this information; items that appear on the list of the largest regional exports (Table 12.1) are highlighted in boldface.

Strong similarities are observed in the profile of exports to these three destinations. Electronic microcircuits (SITC 776.4) are the largest single product in each case, and the seven largest products exported to both Japan and the "rest of the world" appears on the list of the largest goods in regional trade. Approximately 60 percent of the largest products in regional trade are among the largest products exported to other destinations. The profile of East Asia exports is such that it allows the region to capitalize on opportunities in both regional and non-regional markets.

poverty. First, it would increase the level of demand for primary commodities due to increased opportunities for local processing. Second, it appears likely that some of the increased processing would be conducted where the commodities were produced and have a job creation effect. 
Table 12. 1 East Asia's Largest Four-Digit SITC Intra-Regional Export in 2001

\begin{tabular}{|c|c|c|c|c|c|c|}
\hline \multirow[b]{2}{*}{ Commodity (SITC No.) } & \multirow[b]{2}{*}{ Major Supplier (share) } & \multicolumn{2}{|c|}{ Regional Trade ( $\$$ million) } & \multicolumn{2}{|c|}{ Share of Total $(\%)$} & \multirow{2}{*}{$\begin{array}{l}\text { Growth } \\
\text { Rate (\%) }\end{array}$} \\
\hline & & 1985 & 2001 & 1985 & 2001 & \\
\hline Electronic microcircuits (776.4) & Malaysia (23) & $1,106.5$ & $48,975.0$ & 2.26 & 12.43 & 26.7 \\
\hline Parts of office machinery (759.9) & China (25) & 294.0 & $22,365.9$ & 0.60 & 5.67 & 31.1 \\
\hline Parts of telecommunications equipment (764.9) & China (45) & 644.7 & $9,840.7$ & 1.32 & 2.50 & 18.6 \\
\hline Radiotelegraphic and telephonic equipment (764.3) & Korea (32) & 6.6 & $8,334.0$ & 0.01 & 2.11 & 56.3 \\
\hline Digital central storage units (752.4) & Singapore (23) & 0.1 & $8,184.7$ & -- & 2.08 & 98.9 \\
\hline Petroleum oils (333.0) & Indonesia (30) & $5,903.6$ & $6,287.2$ & 12.06 & 1.60 & 0.4 \\
\hline Diodes and transistors (776.3) & Malaysia (20) & 283.5 & $6,208.9$ & 0.58 & 1.58 & 21.3 \\
\hline Children's toy and games (894.2) & China $(\overline{9} 5)$ & 947.8 & $6,127.8$ & 1.94 & 1.55 & 12.4 \\
\hline Other electrical machinery (778.8) & China (28) & 199.4 & $6,050.9$ & 0.41 & 1.54 & 23.8 \\
\hline Piezo-electric crystals (776.8) & Taiwan (24) & 329.2 & $5,500.8$ & 0.67 & 1.40 & 19.2 \\
\hline Peripheral control units (752.5) & China (33) & 85.4 & $5,344.5$ & 0.17 & 1.36 & 29.5 \\
\hline Footwear (851.0) & China (93) & 188.1. & $5,190.0$ & 0.38 & 1.32 & 23.0 \\
\hline Other electrical power machinery (771.2) & China (56) & 128.7 & $4,511.4$ & 0.26 & 1.14 & 24.9 \\
\hline Electrical switches and relays (772.1) & China (35) & 177.2 & $4,481.2$ & 0.36 & 1.14 & 22.4 \\
\hline Printed circuits and parts thereof (772.2) & Taiwan (28) & 133.1 & $4,474.5$ & 0.27 & 1.14 & 24.6 \\
\hline Jerseys and pullovers (845.1) & China (88) & 238.3 & $4,063.9$ & 0.49 & 1.03 & 19.4 \\
\hline Polystyrene (583.3) & Taiwan (44) & 131.7 & $4,012.0$ & 0.27 & 1.02 & 23.8 \\
\hline Petroleum gases (341.3) & Indonesia (47) & 101.8 & $3,883.1$ & 0.21 & 0.99 & 25.6 \\
\hline Knitted fabrics (655.2) & China (38) & 139.0 & $3,867.3$ & 0.28 & 0.98 & 23.1 \\
\hline Woven fabrics (653.1) & Taiwan (45) & 835.2 & $3,321.0$ & 1.71 & 0.84 & 9.0 \\
\hline Miscellaneous art materials (893.9) & China (54) & 206.7 & $3,304.5$ & 0.42 & 0.84 & 18.9 \\
\hline Travel goods and handbags ( 831.0$)$ & China (95) & 271.9 & $3,293.6$ & 0.56 & 0.84 & 16.9 \\
\hline Electric motors and generators (716.2) & China (46) & 47.9 & $3,104.9$ & 0.10 & 0.79 & 29.8 \\
\hline Specialized machinery and appliances (728.4) & Taiwan (42) & 441.4 & $2,987.6$ & 0.90 & 0.76 & 12.7 \\
\hline Woven cotton fabrics (652.2) & China (48) & $2,370.6$ & $2,898.6$ & 4.84 & 0.74 . & 1.3 \\
\hline Insulated electrical wire and cable (773.1) & China (45) & 133.2 & $2,852.8$ & 0.27 & 0.72 & 21.1 \\
\hline Telephonic electrical line (764.1) & China (61) & 37.2 & $2,740.4$ & 0.08 & 0.70 & 30.8 \\
\hline Other sound recorders $(763.8)$ & China (72) & 71.1 & $2,725.3$ & 0.15 & 0.69 & 25.6 \\
\hline Copper and copper alloys (682.2) & Taiwan (38) & 93.9 & $2,554.4$ & 0.19 & 0.65 & 22.9 \\
\hline Gas oils (334.3) & Singapore (50) & $1,609.4$ & $2,519.1$ & 3.29 & 0.64 & 2.8 \\
\hline ALL ABOVE PRODUCTS & & $17,159,068$ & $200,017,751$ & 35.05 & 50.79 & 16.9 \\
\hline
\end{tabular}

Source: Computations based on UN COMTRADE statistics. 
Table 12.2 East Asia's Thirty Largest Four-Digit SITC Exports to Japan and All Other Non-Regional Countries in 2001

\begin{tabular}{|c|c|c|c|c|c|c|c|}
\hline \multicolumn{4}{|c|}{ EXPORTS TO JAPAN } & \multicolumn{4}{|c|}{ EXPORTS TO ALL OTHER NON-REGIONAL COUNTRIES } \\
\hline SITC & Product Description* & Value $(\$ 000)$ & Share $(\%)$ & SITC & Product Description* & Value $(\$ 000)$ & Share (\%) \\
\hline & TOTAL EXPORTS & $145,002,541$ & 100.00 & & TOTAL TRADE & $572,884,033$ & 100.00 \\
\hline 776.4 & Electronic microcircuits & $8 ; 834,146$ & 6.09 & 776.4 & Electronic microcircuits & $33,851,396$ & 5.91 \\
\hline 341.3 & Petroleum gases & $8,618,857$ & 5.94 & 759.9 & Parts of office machinery & $30,882,450$ & 5.39 \\
\hline 759.9 & Parts of office machinery & $5,064,704$ & 3.49 & 894.2 & Children s toys and games & $22,689,247$ & 3.96 \\
\hline 333.0 & Petroleum oils & $3,385,009$ & 2.33 & 752.4 & Digital central storage units & $21,150,427$ & 3.69 \\
\hline 845.1 & Jerseys and pullovers & $3,043,494$ & 2.10 & 752.5 & Peripheral units $\mathbb{\&}$ adapters & $21,033,579$ & 3.67 \\
\hline 764.9 & Parts of telecom equipment & $2,967,883$ & 2.05 & 851.0 & Footwear & $20,054,966$ & 3.50 \\
\hline 752.5 & Peripheral units including adapters & $2,805,570$ & 1.93 & 764.3 & Radiotelephonic equipment & $12,944,357$ & 2.26 \\
\hline 752.4 & Digital central storage units & $2,784,993$ & 1.92 & 781.0 & Passenger motor cars & $12,461,436$ & 2.18 \\
\hline 334.1 & Motor spirit and other light oils & $2,457,621$ & 1.69 & 763.8 & Other sound recorders & $10,267,198$ & 1.79 \\
\hline 851.0 & Footwear & $2,272,008$ & 1.57 & 752.2 & Complete digital data processing machines & $10,163,693$ & 1.77 \\
\hline 752.3 & Complete digital processing equipment & $2,204,222$ & 1.52 & 845.1 & Jerseys and pullovers & $9,778,780$ & 1.71 \\
\hline 036.0 & Crustaceans & $2,187,799$ & 1.51 & 764.1 & Electric telephonic \& telegraphic line & $8,491,822$ & 1.48 \\
\hline 843.9 & Other textile outer garments & $2,060,961$ & 1.42 & 831.0 & Travel goods and handbags & $8,010,007$ & 1.40 \\
\hline 763.8 & Other sound recorders & $1,904,222$ & 1.31 & 821.9 & Other furniture and parts & $7,934,572$ & 1.39 \\
\hline 761.1 & Color television receivers & $1,874,914$ & 1.29 & 843.9 & Other outer garments of textile fabric & $7,790,250$ & 1.36 \\
\hline 846.2 & Under garments of cotton & $1,789,840$ & 1.23 & 764.9 & Parts of telecom equipment & $7,163,547$ & 1.25 \\
\hline 894.2 & Children s toys and games & $1,764,205$ & 1.22 & 893.9 & Miscellaneous articles & $6,647,579$ & 1.16 \\
\hline 752.2 & Complete digital data processing machines & $1,725,974$ & 1.19 & 778.8 & Other electrical machinery & $5,773,110$ & 1.01 \\
\hline 773.1 & Insulated electrical wire & $1,686,788$ & 1.16 & 845.9 & Other knit outer garments & $5,667,265$ & 0.99 \\
\hline 634.2 & Plywood sheets & $1,592,357$ & 1.10 & 771.2 & Other electric power machinery & $5,435,563$ & 0.95 \\
\hline 831.0 & Travel goods and handbags & $1,575,179$ & 1.09 & 812.4 & Lighting fixtures and fittings & $5,058,851$ & 0.88 \\
\hline 821.9 & Other furniture and parts & $1,544,285$ & 1.07 & 775.8 & Electro-thermal appliances & $4,968,078$ & 0.87 \\
\hline 322.2 & Other coal & $1,422,334$ & 0.98 & 762.8 & Other radio-broadcast receivers & $4,800,235$ & 0.84 \\
\hline 771.2 & Other electric power machinery & $1,416,974$ & 0.98 & 752.8 & Off-line data processing equipment & $4,521,606$ & 0.79 \\
\hline 778.8 & Other electrical equipment & $1,314,368$ & 0.91 & 821.1 & Chairs and other seats & $4,473,660$ & 0.78 \\
\hline 764.1 & Electrical and telephonic line & $1,310,827$ & 0.90 & 772.1 & Electrical switches and relays & $4,203,768$ & 0.73 \\
\hline 845.9 & Other knit outer garments & $1,303,814$ & 0.90 & 333.0 & Petroleum oils & $3,951,801$ & 0.69 \\
\hline 034.2 & Frozen fish (excluding fillets) & $1,235,742$ & 0.85 & 846.2 & Under garments of cotton & $3,840,324$ & 0.67 \\
\hline 772.1 & Electrical switches and relays & $1,216,875$ & 0.84 & 761.1 & Color television receivers & $3,695,114$ & 0.65 \\
\hline 037.1 & Fish, prepared & $1,153,974$ & 0.80 & 772.2 & Printed Circuits and Parts & $\cdot 3,546,071$ & 0.62 \\
\hline
\end{tabular}

* Products whose SITC numbers and descriptions are reported in boldface also occur among the 30 largest regional exports (see Table 11.1). 


\section{Trade Trends 13 \\ Have East Asian Markets Facilitated Export Diversification?}

\section{$\underline{\text { Key Point }}$}

Summary measures of export concentration suggest very little general diversification of exports occurred over 1985-2001 in East Asian intra-trade. However, there are instances involving Korea, the Philippines and Taiwan (China) where exports became more concentrated. The underlying statistics show the trend toward increased concentration of exports in these cases was largely due to a remarkable export expansion for electronic products, or for office machinery parts and components. This greatly increased the importance of these products reiative to other exports.

Does the available evidence suggest regional trade promoted the diversification of East Asian exports? This could be the case if regional markets were an initial base for the launch of new exports, which subsequently were traded elsewhere once positive scale and other "learning" effects were achieved. The question is important since it is generally assumed that the greater the level of diversification the better the prospects a country's regionally or global exports. If only a limited range of tradable goods exist, RTA members may have to rely on third countries for a high share of their imports, and this could reduce perceived benefits from the regional trade scheme. Important negative effects from a high concentration of exports may exist. For example, some studies show countries with highly concentrated exports may experience relatively unstable export earnings, a factor that makes economic planning difficult. ${ }^{21}$

In analyses of the magnitude and effects of trade concentration, three empirical indices often have been employed. These include,

- A count of the number of products exported. Two related problems are how to distinguish between established and marginal exports, and at what level of aggregation should products be defined. UNCTAD adopted an approach that seems sensible and differentiates goods at the four-digit level of the SITC. To be included in the count, a product had to account for at least one-half of one percent of total exports.

- A second index is the share of a country's total exports accounted for by the largest products. Previous studies based this measure on the three, or ten, largest products. The higher the shares of these products the higher is the level of export concentration.

- The so called "Hirschmann" index has been used as a measure of trade concentration (see UNCTAD, various issues). This index ranges between 0 and 1 , with lower values indicating less concentrated trade structures. The Hirschmann index is defined as;

$$
\mathrm{H}_{\mathrm{j}}=\sqrt{ }\left(\Sigma\left(\mathrm{x}_{\mathrm{i}} / \mathrm{X}\right)^{2}\right.
$$

where $x_{i}$ is the value of exports of commodity $i$ (normally defined at the four-digit SITC level) and $X$ is the total value of country j's exports.

${ }^{21}$ For an earlier related analysis see MacBean (1966), while Labys and Montague (1990) and the World Bank (2001b) stress the need for many developing countries to diversify their exports. For recent evidence on the negative impact of unstable export earnings, and the need for diversification, in Sub-Saharan Africa see $\mathrm{Ng}$ and Yeats (2002). 
Table 13.1 presents 1985, 1995 and 2001 results when these concentration indices were calculated for; (i) each individual country's regional trade, (ii) the total intra-trade of all East Asian country's combined, and (iii) for East Asia's global exports. There are instances, involving Cambodia, Hong Kong,

Table 13.1 Changes in Concentration Indices for East Asian Intra-Trade

\begin{tabular}{|c|c|c|c|c|c|}
\hline \multirow[b]{2}{*}{ Exporter } & \multirow[b]{2}{*}{ Year } & \multirow{2}{*}{$\begin{array}{l}\text { No. of Products } \\
\text { Exported }\end{array}$} & \multirow{2}{*}{$\begin{array}{c}\text { Concentration } \\
\text { Index }\end{array}$} & \multicolumn{2}{|c|}{ Products Share in Exports (\%) } \\
\hline & & & & Three Largest & Ten Largest \\
\hline \multirow[t]{3}{*}{ Brunei } & 1985 & 1 & 0.98 & 98.9 & 99.4 \\
\hline & 1995 & 5 & 0.78 & 92.4 & 95.5 \\
\hline & 2001 & 7 & 0.70 & 85.7 & 96.6 \\
\hline \multirow[t]{3}{*}{ Cambodia } & 1985 & 4 & 0.37 & 53.9 & 58.0 \\
\hline & 1995 & 8 & 0.54 & 86.5 & 93.9 \\
\hline & 2001 & 31 & 0.26 & 37.5 & 64.3 \\
\hline \multirow[t]{3}{*}{ China } & 1985 & 37 & 0.18 & 22.1 & 36.8 \\
\hline & 1995 & 51 & 0.12 & 15.8 & 28.7 \\
\hline & 2001 & 45 & 0.12 & 13.1 & 29.3 \\
\hline \multirow[t]{3}{*}{ Hong Kong, China } & 1985 & 24 & 0.26 & 39.0 & 58.9 \\
\hline & 1995 & 39 & 0.15 & 19.7 & 36.1 \\
\hline & 2001 & 45 & 0.16 & 21.0 & 37.3 \\
\hline \multirow[t]{3}{*}{ Indonesia } & 1985 & 20 & 0.46 & 64.3 & 80.7 \\
\hline & 1995 & 30 & 0.23 & 37.3 & 56.6 \\
\hline & 2001 & 37 & 0.19 & 27.8 & 45.5 \\
\hline \multirow[t]{3}{*}{ Korea } & 1985 & 46 & 0.16 & 19.7 & 35.5 \\
\hline & 1995 & 43 & 0.19 & 24.5 & 38.7 \\
\hline & 2001 & 45 & 0.16 & 20.9 & 35.2 \\
\hline \multirow[t]{3}{*}{ Laos } & 1985 & 9 & 0.75 & 90.6 & 96.6 \\
\hline & 1995 & 16 & 0.45 & 62.9 & 91.9 \\
\hline & 2001 & 18 & 0.53 & 73.2 & 87.9 \\
\hline \multirow[t]{3}{*}{ Malaysia } & 1985 & 20 & 0.37 & 51.8 & 72.8 \\
\hline & 1995 & 39 & 0.18 & 23.0 & 43.7 \\
\hline & 2001 & 31 & 0.29 & 40.2 & 55.6 \\
\hline \multirow[t]{3}{*}{ Mongolia } & 1985 & 9 & 0.63 & 81.8 & 98.5 \\
\hline & 1995 & 19 & 0.37 & 49.2 & 83.9 \\
\hline & 2001 & 15 & 0.73 & 79.0 & 92.8 \\
\hline \multirow{3}{*}{ Philippines } & 1985 & 32 & 0.29 & 37.9 & 59.4 \\
\hline & 1995 & 27 & 0.30 & 45.1 & 65.0 \\
\hline & 2001 & 19 & 0.49 & 64.0 & 78.3 \\
\hline \multirow[t]{3}{*}{ Singapore } & 1985 & 32 & 0.24 & 35.4 & 54.4 \\
\hline & 1995 & 36 & 0.17 & 23.0 & 41.2 \\
\hline & 2001 & 39 & 0.23 & 30.1 & 48.6 \\
\hline \multirow[t]{3}{*}{ Taiwan, China } & 1985 & 47 & 0.12 & 14.5 & 29.3 \\
\hline & 1995 & 43 & 0.12 & 13.3 & 31.7 \\
\hline & 2001 & 40 & 0.21 & 27.1 & 41.5 \\
\hline
\end{tabular}


Table 13.1 Continued

\begin{tabular}{|l|c|c|c|c|c|}
\hline & & No. of Products & Concentration & \multicolumn{2}{|c|}{ Products Share in Exports (\%) } \\
\cline { 5 - 6 } Country & Year & Exported & Index & Three Largest & Ten Largest \\
\hline Thailand & 1985 & 27 & 0.22 & 32.5 & 53.9 \\
& 1995 & 35 & 0.19 & 26.8 & 46.8 \\
& 2001 & 37 & 0.18 & 27.0 & 41.9 \\
Vietnam & & & & & \\
& 1985 & 25 & 0.36 & 53.8 & 76.3 \\
& 1995 & 36 & 0.25 & 38.3 & 57.9 \\
All Above Countries & 2001 & 28 & 0.42 & 48.7 & 62.8 \\
& 1985 & 36 & & & \\
& 1995 & 45 & 0.15 & 20.2 & 34.6 \\
MEMO ITEM & 2001 & 41 & 0.11 & 13.7 & 24.5 \\
East Asian Global & 1985 & & & 20.6 & 32.4 \\
Exports & 1995 & 45 & & & \\
& & 46 & 0.11 & 13.4 & 28.0 \\
& & & 0.14 & 17.0 & 34.3 \\
\hline
\end{tabular}

Source: UN COMTRADE Statistics.

Indonesia, Laos, Mongolia and Thailand where an important diversification of exports occurred. ${ }^{22}$ For example, over 1985-2001 the numbier of Cambodia's regional export products rose more than ten fold (from 3 to 31), while the share of Indonesia's three largest exports fell from 64 to 28 percent. However, there are several instances involving the Philippines, Taiwan (China) and Korea where the Hirschmann, and other indices, reflect an increased concentration of exports. What factors were responsible for these divergent trends?

For an initial appraisal, these three countries current largest export products were identified. The value and export share of these items was tabulated and compared with similar information for 1985 (see Table 13.2). Two points emerge from these comparisons. First, a remarkable relative increase occurred in the importance of exports of electronic goods and components which did, in fact, cause the overall structure of exports to become more concentrated. For example, the share of electronic microcircuits (SITC 776.6) in Taiwan's exports rose from 1.2 to almost 19 percent over 1985 to 2001 . A similar increase occurred in the relative importance of this product in Korean and the Philippines exports. Second, increased electronic or machinery component exports figure prominently in the trade of all three countries (a point that underscores the growing importance of international production sharing in the region (see Trade Trends 1719). In short, the statistics in Table 13.2 indicating increasingly concentrated trade structures for these countries can largely be explained by' the rapid expansion of these types of specialized products which grew at rates far in excess of those for other established exports.

\footnotetext{
${ }^{22}$ The 1985-2001 export share of the three largest products fell by 10 percentage points or more in the case of Brunei, Cambodia, Hong Kong, Indonesia, Laos and Malaysia. Hong Kong and Indonesia recorded the largest reductions in their 10 product export shares, that is, 22 and 35 percentage points, respectively. For Indonesia the reduction was largely due to a decline in the relative importance of petroleum exports.
} 
Finally, in answer to the question posed in Trade Trends 6 the available evidence does not support the proposition that regional markets fostered a general diversification of exports. From 1995 to 2001 the share of the three largest products in regional trade rose by 7 percentage points to approximately the same level as in 1985. Similar changes occurred in the concentration index and the export product count. These developments do not appear to be related to the financial crisis, but are seemingly due to intense East Asian demand for several specific electronics products.

Table 13.2 Why Some East Asian Exporters Did Not Diversify! Evidence from Korea, the Philippines, and Taiwan, (China)

\begin{tabular}{|l|c|c|c|c|c|c|}
\hline & \multicolumn{3}{|c|}{$\begin{array}{c}\text { Value of Regional Exports } \\
\text { (\$million) }\end{array}$} & \multicolumn{3}{c|}{$\begin{array}{c}\text { Share of Regional Trade } \\
\text { Exporter/Product/SITC No. }\end{array}$} \\
\cline { 2 - 7 } & 1985 & 1995 & 2001 & 1985 & 1995 & 2001 \\
\hline KOREA & & & & & & \\
ALL GOODS & 2,573 & 39,707 & 52,511 & 100.0 & 100.0 & 100.0 \\
Electronic microcircuits (776.4) & 119 & 6,237 & 6,223 & 4.6 & 15.7 & 11.9 \\
Radiotelephonic gear (764.3) & -- & 75 & 3,151 &.- & 0.2 & 6.0 \\
Electronic peripheral units (752.5) & 1 & 171 & 1,619 & 0.1 & 0.4 & 3.1 \\
Parts of telecommunications (764.9) & 34 & 876 & 1,293 & 1.3 & 2.2 & 2.5 \\
& & & & & & \\
PHILIPPINES & & & & & & \\
ALL GOODS & 1,120 & 4,596 & 14,727 & 100.0 & 100.0 & 100.0 \\
Electronic microcircuits (776.4) & 294 & 1,100 & 6,898 & 26.2 & 23.9 & 46.8 \\
Parts of office machinery (759.9) & 23 & 576 & 1,358 & 2.0 & 12.5 & 9.2 \\
Digital storage units (752.4) & 0 & 201 & 1,170 & 0.0 & 4.4 & 7.9 \\
Diodes and transistors (776.3) & 7 & 223 & 575 & 0.6 & 4.8 & 3.9 \\
& & & & & & \\
TAIWAN, (CHINA) & & & & & & \\
ALL GOODS & 5,525 & 49,927 & 59,992 & 100.0 & 100.0 & 100.0 \\
Electronic microcircuits (776.4) & 66 & 3,060 & 11,136 & 1.2 & 6.1 & 18.6 \\
Parts of office machinery (759.8) & 43 & 1,312 & 3,390 & 0.8 & 2.6 & 5.7 \\
Polystyrene (583.3) & 49 & 1,781 & 1,757 & 0.9 & 3.6 & 2.9 \\
\hline
\end{tabular}

Source: UN COMTRADE statistics.

Trade Trends 14

Are There "Dynamic" East Asian Exports

$\underline{\text { Key Point }}$

Manufactured goods that are high skill and highly technology intensive in production comprise a large share of East Asia's fastest growing products in regional trade. Electrical machinery accounts for about one-fifth (by value) of this exchange. East Asia is in the enviable position of having many of its fastest growing regional exports included on a list of its largest export products.

Although they presently may not constitute a large share of East Asian exports, there are reasons why one should attempt to identify "dynamic" (that is, fast growing) exports. Even though their current trade may be small, if their above-average growth continues for an extended period, these items eventually could become an importance source of export earnings. Second, if the dynamic products have common production characteristics, this could convey important information. For example, if they are (say) highly labor- or resource-intensive, both the reasons for their growth and whether similar export opportunities exist in related goods could have important implications. Third, there is an obvious interest in identifying 
dynamic products to focus attention on the removal of any trade barriers they face in possible regional trade arrangement negotiations. Fourth, correlations show a relatively strong relationship exists between the growth rates for specific manufactures in the 1980s and 1990s (Yeats 1999). As such, the identification of current dynamic products may provide useful information concerning their future growth prospects.

Table 14.1 lists the fastest-growing four-digit (Rev. 2) export products in regional trade over the recent 1995-2001 period. It shows the value of exports in each year, each item's percentage increase, and (where possible) whether or not the item is normally produced by labor- or capital- or skill intensive manufacturing procedures. These classifications are based on an UNCTAD (Mayer et. al. 2002, p. 27) analysis that attempted to identify the fastest growing products in world trade. To guard against the results being biased by items with a very low initial trade base, products were excluded if they failed to account for at least one-half of one percent of total 1995 intra-regional exports. Product descriptions are highlighted in boldface if the item was also classified as one of the regions largest exports (see Table 12.1). Finally, the largest regional exporter(s) of each item is identified and its trade share is shown.

Three important points emerge from the information presented in Table 14.1,

- High technology and high skill intensities are frequent characteristics of East Asia's fastest growing exports. Almost one-half of the products listed are classified as high skill, high capital and high scale intensive manufactures, while 22 percent are medium intensive in the use of these factors. In contrast, only three of the products, all of which are articles of clothing, are normally manufactured using labor-intensive processes.

- Electrical machinery (SITC 77) accounts for the largest number of products listed in the table (8 of the four-digit items), and about one-fifth ( $\$ 83$ billion) of the total value of dynamic product exports. The export value of these goods doubled over 1995-2001. Within this group, intra-regional trade in electronic microcircuits (SITC 776.4) was approximately $\$ 50$ billion. Office machinery and equipment (SITC 75) is the second largest group with regional trade of about $\$ 36$ billion.

- East Asia is in the enviable position of having many of its largest regional exports (identified in boldface) included in the "dynamic" or fast growing product group. Approximately 56 percent of the dynamic products, which accounted for $\$ 137$ billion of intra-regional trade, also appear in the region's largest product list (see Table 12.1).

\section{Trade Trends 15 \\ Has Intra-Industry Trade Facilitated the Expansion of East Asian Exports?}

\section{$\underline{\text { Key Point }}$}

A growing level of intra-industry trade can improve a country's prospects for development and growth, expand the range of products available to consumers, and also increase its interdependence in the global economy. Available evidence shows that East Asian intra-industry trade has been steadily growing in relative importance. These trends are evident in trade both within the region, and in trade with major global markets.

Some analyses of factors promoting regional trade and growth conclude a growing level of interindustry trade (IIT) can play an important positive role (see Grubel and Lloyd 1975, Greenway et. al. 1994, Feenstra 1998, or Hoekman and Djankov 1996). There are several reasons for this assumption. First, intra-industry exchange produces gains from international trade, over and above those from comparative advantage, because it allows countries to take advantage of larger markets. By engaging in IIT, a country can often simultaneously reduce the number of similar goods it produces, while the variety of goods available to consumers is increased. By manufacturing fewer varieties, a country can produce each on a larger scale, often with higher productivity and lower cost. 
Table 14. 1 East Asian Countries "Dynamic" Four-Digit SITC Revision 2 Intra-Regional Export Products

\begin{tabular}{|c|c|c|c|c|c|}
\hline \multirow[b]{2}{*}{ Commodity (SITC No.) } & \multirow{2}{*}{$\begin{array}{l}\text { Major } 2001 \text { Supplier(s) } \\
\text { and Share (\%) }\end{array}$} & \multicolumn{2}{|c|}{$\begin{array}{c}\text { Regional Trade Value } \\
(\$ 000)\end{array}$} & \multirow{2}{*}{$\begin{array}{c}2001 \\
\text { Export } \\
\text { Share (\%) }\end{array}$} & \multirow{2}{*}{$\begin{array}{c}\text { Percentage } \\
\text { Increase } \\
(\%)\end{array}$} \\
\hline & & 1995 & 2001 & & \\
\hline Radiotelegraphic \& telephonic equipment $(764.3)^{\star}$ & Korea (38), China (29) & $1,181,223$ & $8,333,994$ & 2.11 & 605.5 \\
\hline Peripheral electronic units $(\mathbf{7 5 2 . 5})^{\star}$ & China (33), Korea (30) & $1,474,474$ & $5,344,467$ & 1.36 & 262.5 \\
\hline Digital central storage units $(\mathbf{7 5 2 . 4})^{\star}$ & Singapore (23), China (19) & $3,324,042$ & $8,194,712$ & 2.08 & 146.5 \\
\hline Piezo-electric crystals $(776.8)^{\star}$ & Taiwan (24), Singapore (20) & $2,362,571$ & $5,500,780$ & 1.4 & 132.8 \\
\hline Electronic microcircuits $(776.4)^{\star}$ & Malaysia (23), Taiwan (23) & $22,762,712$ & $48,975,040$ & 12.43 & 115.2 \\
\hline Other coal (322.2) & China (58), Indonesia (41) & $1,132,592$ & $2,404,728$ & 0.61 & 112.3 \\
\hline Parts of office machinery $(759.9)^{\star}$ & China (34), Malaysia (33) & $10,608,952$ & $22,365,857$ & 5.67 & 110.8 \\
\hline Printed circuits and parts $(772.2)^{\star \star}$ & Taiwan (28), China (27) & $2,136,143$ & $4,474,498$ & 1.14 & 109.5 \\
\hline Jerseys and, pullovers $(845.1)^{\star \star \star \star}$ & China (89) & $2,043,761$ & $4,063,947$ & 1.03 & 98.8 \\
\hline Diodes and transistors $\left(\mathbf{7 7 6 . 3 ) ^ { \star }}\right.$ & Malaysia (25), Taiwan (20) & $3,280,603$ & $6,208,868$ & 1.58 & 89.3 \\
\hline Petroleum gases (341.3) & Indonesia (47), Malaysia (32) & $2,075,375$ & $3,883,072$ & 0.99 & 87.1 \\
\hline Fuel oils (334.4) & Singapore (48) & $1,065,655$ & $1,960,483$ & 0.5 & 84.0 \\
\hline Other outer garments $(845.9)^{* * * *}$ & China (84) & $1,377,805$ & $2,420,411$ & 0.61 & 75.7 \\
\hline Other electric power machinery $(771.2)^{\star \star}$ & China (56) & $2,682,822$ & $4,511,373$ & 1.14 & 68.2 \\
\hline Iron sheets \& plates $(674.6)^{* * *}$ & Taiwan (48), Korea (40) & $1,334,516$ & $2,237,419$ & 0.57 & 67.7 \\
\hline Other electrical machinery $(\mathbf{7 7 8 . 8})^{\star \star}$ & China (28), Taiwan (19) & $3,635,115$ & $6,050,890$ & 1.54 & 66.5 \\
\hline Electrical switches and relays $(772.1)^{\star \star}$ & China (36), Taiwan (16) & $2,825,977$ & $4,481,204$ & 1.14 & 58.6 \\
\hline Telephonic equipment $(764.1)^{\star}$ & China (61), Taiwan (12) & $1,755,083$ & $2,740,412$ & 0.7 & 56.1 \\
\hline Polyethylene $(583.1)^{*}$ & Korea (37), Singapore (21) & $1,305,583$ & $2,037,600$ & 0.52 & 56.1 \\
\hline Kerosene and other medium oils ( 334.2 ) & Singapore (46) & $1,123,867$ & $1,666,733$ & 0.42 & 48.3 \\
\hline Cameras and camera parts $(881.1)^{*}$ & China (59) & $1,333,829$ & $1,967,849$ & 0.5 & 47.5 \\
\hline Other outer garments $(843.9)^{* * * *}$ & China (87) & $1,441,471$ & $2,125,397$ & 0.54 & 47.4 \\
\hline Polypropylene $(583.2)^{*}$ & Korea (36), Taiwan (24) & $1,136,868$ & $1,665,179$ & 0.42 & 46.5 \\
\hline Electric motors \& generators $(716.2)^{\star \star}$ & China (46), Thailand (17) & $2,153,960$ & $3,104,906$ & 0.79 & 44.1 \\
\hline Other polymerization material $(583.9)^{*}$ & Taiwan (30), Korea (26) & $1,364,979$ & $1,944,928$ & 0.49 & 42.5 \\
\hline Insulated wire and cable $(773.1)^{\star *}$ & China (45), Taiwan (15) & $2,026,478$ & $2,852,770$ & 0.72 & 40.8 \\
\hline Cyclic hydrocarbons (511.2)* & Korea (58), Singapore (17) & $1,399,254$ & $1,968,195$ & 0.5 & 40.7 \\
\hline All goods & & $303,521,831$ & $394,140,708$ & 100 & 29.9 \\
\hline
\end{tabular}

* Classified by UNCTAD (2002, p. 27) as a high skill, technology-, capital and scale intensive manufactured good.

** Classified as a medium skill, medium capital and scale intensive manufactured good.

*** Classified as a low skill, low capital and scale intensive manufactured good.

**** Classified as a labor intensive manufactured good.

Note: Products whose description is highlighted are also classified as one of the region's largest exports. 
Several summary measures provide useful insights as to the extent that IIT is taking place or is changing. One such measure is the IIT ratio. This index ranges between zero and one, with larger values indicating greater trade between firms in the same industry. Higher IIT ratios suggest that gains from specialization in differentiated products are being exploited, and that the participating country is increasing its interdependence with regional or global markets. ${ }^{23}$

Table 15.1 presents 1985 and 2001 East Asian regional intra-trade ratios for all manufactured goods as well as several fabricated product sub-groups. To help visualize the pattern of changes, situations where the IIT index rose by a factor of 0.100 , or more, are marked with an asterisk. An analysis of IIT indices in other published studies suggests this magnitude of change constitutes a relatively strong increase in intra-industry trade. These statistics show that overall intra-industry trade generally strengthened for most regional countries Brunei, Cambodia, and Laos are exceptions as little or no "base" for this activity seemingly has been established. Also, somewhat different patterns occur between the product groups. For example, the 1985-2001 IIT indices for manufactures rose for all but two of the East Asian countries, and 9 of the 14 East Asian countries registered an increase in excess of $0.100 .^{24}$ The regional intraindustry trade ratios for Indonesia and Taiwan more than doubled to relatively high (approximately 0.500) values. ${ }^{25}$ However, the trend toward increased intra-industry trade appears weaker within the chemical products sector where the indices declined for 5 of the 14 regional countries.

Are the intra-industry trade trends within East Asia unusual, or do they basically reflect the region's experience in global markets. Table 15.1 provides relevant information by showing 1985, 1995 and 2001 IIT indices for East Asia's trade with Japan, NAFTA, and the European Union (15). Strong similarities are evident in East Asia's IIT trends for both intra- and inter-regional trade. The 1985-2001 intra-industry ratios for trade in all manufacture goods with Japan more than doubled (from 0.199 to 0.462), while significant increases are also reported for the European Union (15) and NAFTA. Even during the recent 1995-2001 period, that covered the financial crisis, the IIT ratios generally tended to increase. In short, the statistics provide strong evidence as to East Asia's continuing successful expansion into both regional and global markets.

${ }^{23}$ The IIT index is defined as,

$$
I I T=1-\left[\sum \sum \sum\left|X_{i j k}-M_{i j k}\right| \div\left(X_{i j k}+M_{i j k}\right)\right]
$$

Where $X_{i j k}$ represents exports from industry $i$ by country $j$ to country $k$, and $M_{i j k}$ represents corresponding import values. Industries are defined at the three-digit level of the SITC system and the analysis is confined to manufactured goods, that is, items classified in SITC groups 5 through 8 less nonferrous metals

${ }^{24}$ Assembly operations for foreign produced parts and components are one reason for the increase in some IIT ratios. Machinery parts and components are normally classified in the same SITC category as their final stage product so the import of components for assembly, and the export of the final (assembled) stage good, is reflected in the IIT ratios. Lemoine and Unal-Kasenci (2002) report that over 90 percent of China's exports and imports of high technology goods occur in the same product sectors due to assembly operations.

${ }^{25}$ Kierzkowski (2001, p. 239) provides statistics on intra-industry trade ratios for 45 countries who trade with the European Union. This information should help assess implications of the statistics in Table 15.1. In general, many of the East Asian IIT indices appear relatively high. For example, Kierzkowski calculates an index of 0.274 and 0.432 for Greece and Portugal's (both EU members) trade with the European Union, while the indices for Poland and Hungary are 0.437 and 0.509 , respectively. 
Table 15.1 Intra-Industry Trade Ratios for Individual East Asian Regional Trade in 1985, 1995 and 2001

\begin{tabular}{|c|c|c|c|c|c|c|c|c|c|c|c|c|}
\hline \multirow[b]{2}{*}{ Country } & \multicolumn{3}{|c|}{ Chemicals } & \multicolumn{3}{|c|}{ Machinery \& Transport } & \multicolumn{3}{|c|}{ Other Manufactures } & \multicolumn{3}{|c|}{ All Manufactures } \\
\hline & 1985 & 1995 & 2001 & 1985 & 1995 & 2001 & 1985 & 1995 & 2001 & 1985 & 1995 & 2001 \\
\hline Brunei Darussalam & 0.041 & 0.011 & 0.016 & 0.080 & 0.045 & 0.016 & 0.091 & 0.040 & 0.115 & 0.080 & 0.040 & 0.075 \\
\hline Cambodia & 0.004 & 0.023 & 0.005 & 0.000 & 0.010 & 0.064 & 0.000 & 0.044 & 0.060 & 0.001 & 0.023 & 0.056 \\
\hline China & 0.214 & $0.423^{*}$ & $0.382^{*}$ & 0.522 & 0.385 & 0.458 & 0.285 & 0.225 & 0.282 & 0.322 & 0.287 & 0.365 \\
\hline Hong Kong & 0.368 & 0.238 & 0.304 & 0.544 & 0.458 & 0.337 & 0.336 & 0.303 & 0.314 & 0.422 & 0.359 & 0.326 \\
\hline Indonesia & 0.303 & $0.653^{*}$ & $0.672^{*}$ & 0.112 & $0.343^{*}$ & $0.571^{*}$ & 0.226 & $0.341^{*}$ & $0.366^{*}$ & 0.223 & $0.397^{*}$ & $0.509^{*}$ \\
\hline Korea & 0.324 & 0.320 & 0.314 & 0.313 & 0.384 & $0.606^{*}$ & 0.228 & $0.427^{*}$ & $0.399 *$ & 0.271 & $0.393^{*}$ & $0.498^{*}$ \\
\hline Lao P. D. Rep. & 0.000 & $0.260^{*}$ & 0.010 & 0.004 & 0.006 & 0.033 & 0.003 & 0.033 & 0.029 & 0.002 & 0.043 & 0.029 \\
\hline Malaysia & 0.359 & $0.617^{*}$ & $0.743^{*}$ & 0.709 & 0.742 & 0.749 & 0.444 & $0.564^{*}$ & $0.681^{*}$ & 0.588 & $0.693^{*}$ & $0.738 *$ \\
\hline Mongolia & - & $0.109^{*}$ & 0.003 & -- & 0.006 & 0.005 & -- & 0.050 & $0.226^{*}$ & - & 0.045 & $0.140^{*}$ \\
\hline Philippines & 0.507 & 0.240 & 0.305 & 0.446 & $0.563^{*}$ & 0.525 & 0.212 & 0.212 & $0.334^{*}$ & 0.379 & 0.418 & $0.484^{*}$ \\
\hline Singapore & 0.344 & $0.526^{*}$ & 0.392 & 0.838 & 0.804 & 0.810 & 0.430 & 0.503 & $0.607^{*}$ & 0.638 & 0.728 & $0.746^{*}$ \\
\hline Taiwan, China & 0.343 & 0.288 & 0.344 & 0.282 & $0.545^{*}$ & $0.646^{*}$ & 0.150 & $0.292^{*}$ & $0.305^{*}$ & 0.213 & $0.411^{*}$ & $0.519^{*}$ \\
\hline Thailand & 0.284 & $0.455^{*}$ & $0.467^{*}$ & 0.530 & $0.719^{*}$ & $0.775^{*}$ & 0.508 & 0.550 & 0.579 & 0.473 & $0.645^{*}$ & $0.692^{*}$ \\
\hline Vietnam & 0.009 & 0.060 & 0.142 & 0.114 & 0.078 & $0.241^{*}$ & 0.033 & $0.172^{*}$ & $0.211^{*}$ & 0.027 & 0.119 & $0.211^{*}$ \\
\hline Average of Above & 0.221 & 0.302 & 0.292 & 0.321 & 0.362 & 0.416 & 0.210 & 0.268 & $0.322 *$ & 0.260 & 0.329 & $0.384^{*}$ \\
\hline & & & & & & & & & & & & \\
\hline $\begin{array}{l}\text { MEMO ITEM } \\
\text { IIT for Trade with: }\end{array}$ & & & & & & & & & & & & \\
\hline Japan & 0.362 & 0.343 & $0.473^{*}$ & 0.104 & $0.354^{*}$ & $0.534^{*}$ & 0.277 & 0.327 & 0.342 & 0.199 & $0.344^{*}$ & $0.462^{*}$ \\
\hline NAFTA & 0.337 & 0.344 & $0.594^{*}$ & 0.483 & 0.482 & 0.429 & 0.100 & $0.209^{*}$ & 0.164 & 0.275 & 0.374 & 0.337 \\
\hline EU (15) & 0.290 & $0.503^{*}$ & $0.577^{*}$ & 0.328 & 0.401 & $0.516^{*}$ & 0.287 & $0.396^{*}$ & 0.362 & 0.305 & $0.407^{*}$ & 0.465 * \\
\hline
\end{tabular}

* The regional intra-industry trade index increased by 0.100 or more over the 1985 level.

Source: Computations based on UN COMTRADE statistics. 
Trade Trends 16

Have East Asian Countries "Re-Orientated" Their Exports?

$\underline{\text { Key Point }}$

According to the Asian Development Bank, recent evidence pertaining to MERCOSUR shows that a regional trade arrangement can distort the composition and direction of member countries' trade in ways that incorporate major economic inefficiencies. Although East Asian RTAs (like ASEAN) are weaker a reorientation of trade may be occurring. However, an analysis of regional trade changes shows these negative trends are not occurring within East Asia even though the relative importance of intra-trade has grown very rapidly. Rather, East Asia's global and regional exports appear to be evolving in ways that are fully consistent with these countries' comparative advantage.

Any assessment of the effects of an established regional trade arrangement should consider how it influenced the direction and composition of trade. If substantial trade diversion occurred this could have important negative implications for third countries whose exports have been displaced. Second, the effects on the product composition of trade can be equally important. If an RTA stimulates intra-trade in products in which members do not have a cornparative advantage serious economic losses and inefficiencies may occur. The Asian Development Bank (2002, p. 187) cites evidence showing MERCOSUR had such negative economic effects through the "re-orientation" of member countries trade toward each other,

"Inter-block trade in MERCOSUR increased at the expense of trade with non-member countries and caused significant trade diversion. This stemmed from the groups "discriminatory" tariffs against nonmembers which are four to six tirnes higher than those in other major preferential trade arrangements. The trade block appears to reinforce the inward orientation of MERCOSUR economies enabling inefficient domestic producers to expand marketsi within the block remaining uncompetitive on the wider international scene. The decline in MERCOSUR trade (both within and outside of the bloc) in the late 1990s reflects the impact of accumulated inefficiencies sustained through relatively high discriminatory protection. The MERCOSUR case highlights the importance of examining broader economic policies - rather than just looking at trade flows - when analyzing the impact of preferential trade arrangements."

These observations raise an important issue. Have East Asian countries been re-orienting their own trade toward each other. If they have, has the re-orientation been along lines consistent with comparative advantage or is it likely that important inefficiencies are involved? For example, in the case of MERCOSUR high discriminatory tariffs promoted intra-trade in highly capital intensive manufactures that could not be exported competitively to third markets. East Asia generally does not apply high discriminatory tariffs, but there are still several reasons why questions concerning the re-orientation of regional trade should be addressed;

- The Asian Development Bank (2002, p. 185) cites evidence showing that, "since Lao PDR, Myanmar and Vietnam joined the ASEAN preferential trade arrangement between 1995 and 1998, a sharp increase in their within-block trade occurred." Similar shifts in the direction of trade may have occurred for other ASEAN countries. This re-orientation of trade may have been further encouraged by several trade facilitation and trade agreements such as the ASEAN Industrial Cooperation Scheme (which provides preferential tariffs for ASEAN owned enterprises), or the ASEAN Customs Vision 2020 agreement that attempts to streamline and simplify customs clearance procedures.

- Preferential trade arrangements in non-regional markets may have caused East Asian countries to re-direct their trade toward each other. For example, over the last decade NAFTA and MERCOSUR were formed, and the EU agreement was strengthened and expanded. These developments could have worsened relative market access conditions for East Asian exporters in North America and Europe, and caused some trade to be diverted to regional markets (Asian Development Bank 2002, p. 188).

- Exporters may have been motivated to re-orient exports toward the region by special trade facilitation arrangements, like the China-ASEAN framework agreement, which includes provisions for 
future preferential tariffs, that streamlines and simplifies procedures for international trade. The incentive to re-orient trade could be significant if the framework agreements were viewed as precursors of formal preferential trade arrangements. The establishment and operation of special economic growth zone may also have caused a re-orientation of exports as local entrepreneurs attempt to capitalize on opportunities in these areas.

An empirical measure is available that can provide useful insights concerning changes in the nature and composition of goods traded regionally. This measure, referred to as the regional "orientation" index for country $i$ and good $j$, is defined as,

$$
R O_{i r}=\frac{\text { (share of } j \text { in country } i \text { 's exports to the region) }}{\text { (share of } j \text { in country i's non-regional exports) }}
$$

The interpretation of this measure is somewhat similar to that for the standard RCA index. If the index exceeds unity the country has a higher than expected propensity to export product $j$ to regional markets. If $\mathrm{RO}_{\mathrm{ir}}$ is below unity the propensity to export $\mathrm{j}$ is lower than expected. Changes in the index over time are of particular interest since increases (decreases) indicate a growing (declining) regional orientation of trade in a specific product. See Yeats (1998) for a previous application of the regional orientation index.

Table 16.1 reports individual East Asian country's 1985 and 2001 regional orientation indices for broad product groups like foodstuffs, chemicals and mineral fuels, as well as similar information for the combined exports of these countries. To help identify any underlying trends, the last line of the table shows the 1985-2001 overall change in each of the product group's indices. ${ }^{26}$

The major impression conveyed by Table 16.1 is that, with one exception (ores and metals), no major unexpected re-orientation occurred in the broad composition of goods destined for regional markets, even though the overall relative importance of intra-trade has increased dramatically (see Table 2.1). ${ }^{27}$ Stated differently, East Asia's exports for these major product groups expanded at approximately the same pace in both regional and global markets. This point is reflected in the virtually unchanged RO index for machinery and transport manufactures (an index of 1.004 in 1985 versus 1.021 in 2001) as well as the relatively static indices for the other broad product groups.

A specific example may help the pattern of results reported in Table 16.1. Trade Trends 14 determined that machinery and transport products were among the largest and most dynamic (that is, fastest growing) products in regional trade. Was the dynamism the result of diversion of exports from global to regional markets? No! As previously noted in Trade Trends 11 "Since 1985 the product composition of East Asian intra-trade changed dramatically as the share of machinery and transport equipment rose by over 26 percentage points. At present these goods account for approximately one half of all goods traded within the region. A similar pattern is observed in non-regional trade as the share of machinery and transport equipment rose from 18 to 46 percent." East Asia's trade performance shows it is fully competitive for these types of goods in both regional and global markets. As such, the evidence

${ }^{26}$ Clearly, factors influencing global trading conditions could also have a major influence on the RO index apart from closer economic ties within East Asia. For example, the Uruguay Round agreement significantly liberalized barriers to trade in some products like steel, textiles and clothing that may have enhanced export opportunities in global, as opposed to regional markets. Some estimates indicate the Round, when fully implemented, could increase the volume of developing countries' exports by 13 to 36 percent.

${ }^{27}$ The regional orientation index for ores and metals increased by a value of 1.258 over 1985-2001 which is the largest change reported in the table. Analysis of the underlying statistics shows the index change was almost totally accounted for by the redirection of Mongolian, Indonesian and Taiwan's exports of copper alloys and ores toward regional markets. The rapid expansion of regional electronic products, whose production is intensive in the use of copper, clearly contributed to this directional change in trade. 
Table 16.1 East Asian Regional Orientation Indices for Intra-Trade of Broad Product Groups; 1985 and 2001

\begin{tabular}{|c|c|c|c|c|c|c|c|c|c|c|c|}
\hline \multirow[b]{2}{*}{ Exporter } & \multirow[b]{2}{*}{ Year } & \multicolumn{10}{|c|}{ Regional Orientation Indices for Major Product Groups } \\
\hline & & $\begin{array}{c}\text { Food \& } \\
\text { Feeds }\end{array}$ & $\begin{array}{l}\text { Beverages } \\
\& \text { Tobacco }\end{array}$ & $\begin{array}{c}\text { Agricultural } \\
\text { Raw Materials }\end{array}$ & $\begin{array}{l}\text { Ores \& } \\
\text { Metals }\end{array}$ & $\begin{array}{l}\text { Mineral } \\
\text { Fuels }\end{array}$ & $\begin{array}{c}\text { Animal \& } \\
\text { Vegetable Oil }\end{array}$ & Chemicals & $\begin{array}{c}\text { Manufactures } \\
\text { Classified by } \\
\text { Materials }\end{array}$ & $\begin{array}{l}\text { Machinery } \\
\text { \& Transport } \\
\text { Equipment }\end{array}$ & $\begin{array}{c}\text { Misc. } \\
\text { Manufactures }\end{array}$ \\
\hline \multirow[t]{2}{*}{ Brunei } & 1985 & 0.003 & 0.000 & 0.017 & 0.034 & 5.191 & 0.000 & 0.035 & 0.005 & 0.019 & 0.030 \\
\hline & 2001 & 0.009 & 0.010 & 0.065 & 0.154 & 21.511 & 0.000 & 0.013 & 0.629 & 0.076 & 0.029 \\
\hline \multirow[t]{2}{*}{ Cambodia } & 1985 & 3.472 & 0.000 & 14.219 & 0.000 & 0.000 & 0.000 & 0.183 & 0.000 & 0.002 & 0.011 \\
\hline & 2001 & 2.927 & 1.708 & 19.159 & 1.145 & 0.001 & 0.000 & 0.050 & 2.736 & 0.154 & 0.075 \\
\hline \multirow[t]{2}{*}{ China } & 1985 & 1.868 & 2.912 & 1.014 & 0.576 & 1.144 & 0.092 & 1.834 & 1.359 & 0.295 & 0.718 \\
\hline & 2001 & 0.835 & 4.365 & 0.526 & 1.581 & 0.835 & 0.155 & 0.945 & 1.286 & 0.815 & 1.204 \\
\hline \multirow[t]{2}{*}{ Hong Kong, China } & 1985 & 0.299 & 5.877 & 0.645 & 1.007 & 0.087 & 0.186 & 1.992 & 0.863 & 2.339 & 1.039 \\
\hline & 2001 & 0.179 & 2.332 & 0.542 & 1.811 & 0.250 & 0.097 & 1.977 & 1.140 & 1.100 & 0.715 \\
\hline \multirow[t]{2}{*}{ Indonesia } & 1985 & 0.984 & 0.179 & 2.489 & 0.777 & 2.684 & 0.513 & 2.720 & 0.707 & 0.031 & 0.014 \\
\hline & 2001 & 1.424 & 3.713 & 9.072 & 3.364 & 8.397 & 3.588 & 2.873 & 0.852 & 0.303 & 0.098 \\
\hline \multirow[t]{2}{*}{ Korea, Rep } & 1985 & 0.305 & 1.387 & 0.504 & 3.094 & 0.192 & 0.016 & 5.879 & $1.228^{\circ}$ & 1.508 & 0.414 \\
\hline & 2001 & 0.165 & 0.745 & 1.236 & 4.412 & 1.845 & 0.039 & 4.848 & 0.821 & 0.990 & 0.179 \\
\hline \multirow[t]{2}{*}{ Lao, PDR } & 1985 & 6.356 & 0.000 & 9.525 & 0.000 & 0.000 & 0.000 & 0.000 & 0.006 & 0.010 & 0.011 \\
\hline & 2001 & 1.831 & 0.038 & 65.356 & 2.605 & 0.442 & 0.005 & 0.067 & 0.158 & 0.062 & 0.039 \\
\hline \multirow[t]{2}{*}{ Malaysia } & 1985 & 0.705 & 0.552 & 4.019 & 0.338 & 2.024 & 5.350 & 0.597 & 0.227 & 0.825 & 0.085 \\
\hline & 2001 & 0.560 & 5.110 & 1.930 & 1.009 & 2.443 & 4.580 & 1.604 & 0.357 & 1.386 & 0.240 \\
\hline \multirow[t]{2}{*}{ Mongolia } & 1985 & 0.000 & 0.000 & 0.000 & 0.000 & 0.000 & 0.000 & 0.000 & 0.934 & 0.000 & 4.996 \\
\hline & 2001 & 0.242 & 0.007 & 6.347 & 38.860 & 0.171 & 0.008 & 0.003 & 0.662 & 0.001 & 0.001 \\
\hline \multirow[t]{2}{*}{ Philippines } & 1985 & 1.558 & 1.542 & 0.878 & 3.048 & 0.572 & 0.764 & 3.329 & 0.226 & 2.246 & 0.148 \\
\hline & 2001 & 0.794 & 1.283 & 0.242 & 1.539 & 0.335 & 1.251 & 0.473 & 0.114 & 1.832 & 0.123 \\
\hline \multirow[t]{2}{*}{ Singapore } & 1985 & 0.272 & 1.215 & 0.312 & 0.754 & 2.510 & 0.459 & 4.480 & 0.182 & 1.375 & 0.240 \\
\hline & 2001 & 0.241 & 3.274 & 0.264 & 0.761 & 4.099 & 0.242 & 3.575 & 0.178 & 1.291 & 0.285 \\
\hline
\end{tabular}


Table 16. 1 Continued

Regional Orientation Indices for Major Product Group

\begin{tabular}{|c|c|c|c|c|c|c|c|c|c|c|c|}
\hline \multirow[b]{2}{*}{ Exporter } & \multirow[b]{2}{*}{ Year } & \multicolumn{10}{|c|}{ Regional Orientation Indices for Major Product Groups } \\
\hline & & $\begin{array}{c}\text { Food \& } \\
\text { Feeds } \\
\end{array}$ & $\begin{array}{r}\text { Beverages } \\
\& \text { Tobacco } \\
\end{array}$ & $\begin{array}{c}\text { Agricultural } \\
\text { Raw Materials } \\
\end{array}$ & $\begin{array}{l}\text { Ores \& } \\
\text { Metals } \\
\end{array}$ & $\begin{array}{c}\text { Mineral } \\
\text { Fuels }\end{array}$ & $\begin{array}{c}\text { Animal \& } \\
\text { Vegetable Oil } \\
\end{array}$ & Chemicals & $\begin{array}{c}\text { Manufactures } \\
\text { Classified by } \\
\text { Materials } \\
\end{array}$ & $\begin{array}{c}\text { Machinery } \\
\text { \& Transport } \\
\text { Equipment } \\
\end{array}$ & $\begin{array}{c}\text { Misc. } \\
\text { Manufactures } \\
\end{array}$ \\
\hline \multirow[t]{2}{*}{ Taiwan, China } & 1985 & 0.647 & 0.443 & 0.648 & 1.960 & 0.152 & 0.014 & 3.080 & 1.437 & 1.434 & 0.688 \\
\hline & 2001 & 0.208 & 0.466 & 1.086 & 4.148 & 0.280 & 0.056 & 4.173 & 0.805 & 1.145 & 0.283 \\
\hline \multirow[t]{2}{*}{ Thailand } & 1985 & 6.228 & 2.649 & 1.793 & 1.517 & 0.023 & 0.265 & 1.774 & 0.500 & 0.676 & 0.211 \\
\hline & 2001 & 2.709 & 1.830 & 4.473 & 1.470 & 1.486 & 0.609 & 3.537 & 0.467 & 1.083 & 0.173 \\
\hline Vietnam & 2001 & 4.497 & 1.171 & 3.005 & 0.789 & 11.028 & 0.450 & 0.776 & 0.531 & 0.327 & 0.305 \\
\hline \multirow[t]{2}{*}{ All above countries } & 1985 & 1.192 & 1.945 & 1.389 & 1.031 & 1.286 & 1.058 & 2.446 & 0.820 & 1.005 & 0.467 \\
\hline & 2001 & 0.695 & 2.851 & 1.455 & 2.289 & 1.848 & 0.840 & 2.521 & 0.819 & 1.033 & 0.553 \\
\hline \multicolumn{12}{|l|}{ MEMO ITEM } \\
\hline \multicolumn{2}{|c|}{ Net Change: $1985-2001$} & -0.497 & 0.906 & 0.066 & 1.258 & 0.562 & -0.218 & 0.075 & -0.001 & 0.028 & 0.086 \\
\hline
\end{tabular}

Note: The product groups are classified by SITC products in Revision 2 as Foods and Feeds $(0+1+22+4)$; Agricultural raw materials (2-22-27-28); Mineral Fuels (3); Ores and metals (27+28+67+68); Chemicals (5); Machinery and Transport (7); Other Manufactures (6-67-68+84); and Miscellaneous manufactured goods (SITC 8-84). 
indicates East Asia's regional exports expanded along lines consistent with comparative advantage without any significant policy induced distortions.

\section{Trade Trends 17}

\section{How Big is East Asian Production Sharing?}

\section{$\underline{\text { Key Point }}$}

Trade in parts and components has grown steadily in East Asia and now accounts for about $\$ 66$ billion, or over one-fifth of all intra-trade in manufactured goods. Regional trade in parts of office machinery and telecommunications equipment now total about $\$ 43$ billion. The magnitude of production sharing in East Asia would clearly be a positive factor facilitating regional cooperation and increased interdependence.

A growing body of evidence has documented the remarkable increase in international production sharing as reflected in far above average growth rates for trade in components or partially assembled manufactured goods. ${ }^{28}$ Production sharing often involves the development of specialized (often) labor intensive activities within vertically integrated international manufacturing activities. As an example, electronic semi-conductors, valves, tuners and other components are now assembled for multinational firms in places like Malaysia or the Philippines. Parts of wearing apparel and leather goods are assembled in Jamaica and the Dominical Republic for re-export to the US market - one estimate by the World Bank puts the value of assembly exports from the Caribbean at over $\$ 3$ billion. Among the many industries where major parts of a production process were internationalized include television and radio receivers, sewing machines, calculators, office equipment, electrical machinery, power and machine tools, typewriters, cameras and watches (USITC 1994).

In its original form, the Standard International Trade Classification (SITC) system did a less than adequate job of distinguishing between trade in final goods as opposed to parts and components. At its lowest (five-digit) level the SITC Revision 1 identified about 800 individual products - only 10 of which consisted of "parts" of manufactured goods that normally would undergo further assembly. However, in the late 1970s and early 1980s many countries adopted the more detailed SITC Revision 2 system which expanded the number of product groups composed solely of parts and components. The coverage of these groups was most extensive within the machinery and transport equipment sector (SITC 7) where about 60 individual three, four, and five-digit product classifications that consist solely of components of manufactured equipment intended for further assembly. ${ }^{29}$ This data source greatly facilitated empirical analyses relating to production sharing. The recently introduced Harmonized System (HS) trade data classification scheme further expancled the coverage of statistics on trade in parts and components.

${ }^{28}$ Production sharing is the internationalization of a manufacturing process in which several countries participate in different stages of a specific good's fabrication. The process is of considerable economic importance since it allows stages of production to be located where they can be undertaken most efficiently. $\mathrm{Ng}$ and Yeats (1999, p. 13) East Asian intra-trade in goods normally used in production sharing grew at an annual rate of 21 percent from the mid-1980s to mid-1990s. This was approximately 7 percentage points higher than East Asia's intra-trade in all goods.

${ }^{29}$ This analysis is based exclusively' on product groups defined by the UN as consisting solely of parts and components. This almost certainly causes estimates of East Asian production sharing to be downward biased. Some other traded SITC 7 products, like television picture tubes, or threads and fibers in SITC 6 , likely experience further assembly operations, but it is not possible to accurately determine what is their true end use. 
Table 17.1 The 2001 Value and Share of East Asian Regional Trade in Parts and Components (values in \$ 000)

\begin{tabular}{|c|c|c|}
\hline \multirow[b]{2}{*}{ Component Part Description (SITC Number)* } & \multicolumn{2}{|c|}{ Regional Trade } \\
\hline & Value & Share (\%) \\
\hline Steam boilers and auxiliary plants (711.9) & 50,718 & 0.08 \\
\hline Aircraft internal combustion engines (713.19) & 32,184 & 0.05 \\
\hline Outboard Motors (713.31) & 2,619 & 0.00 \\
\hline Outboard motors, nes (713.32) & 80,057 & 0.12 \\
\hline Internal combustion engines, nes (713.9) & 317,289 & 0.48 \\
\hline Engines and motors, nes (714.9) & 170,469 & 0.26 \\
\hline Rotating electric motors (716.9) & 488,209 & 0.74 \\
\hline Water turbines and motors $(718.89)$ & 4,815 & 0.01 \\
\hline Cultivating equipment (721.19) & 9,939 & 0.02 \\
\hline Harvesting machinery (721.29) & 6,965 & 0.01 \\
\hline Dairy machinery (721.39) & 762 & 0.00 \\
\hline Wine making machinery (721.98) & 1,450 & 0.00 \\
\hline Agricultural machinery, nes $(721.99)$ & 11,551 & 0.02 \\
\hline Construction machinery (723.9) & 540,244 & 0.82 \\
\hline Spinning machinery (724.49) & 40,587 & 0.06 \\
\hline Looms and knitting machinery (724.69) & 69,144 & 0.11 \\
\hline Textile machinery, nes (724.79) & 83,248 & 0.13 \\
\hline Paper making machinery (725.9) & 24,573 & 0.04 \\
\hline Bookbinding machinery (726.89) & 850 & 0.00 \\
\hline Printing and typesetting machinery (726.9) & 119,388 & 0.18 \\
\hline Grain milling machinery $(727.19)$ & 7,255 & 0.01 \\
\hline Food processing machinery $(727.29)$ & 14,939 & 0.02 \\
\hline Machines for special industries (728.19) & 63,660 & 0.10 \\
\hline Mineral working machinery (728.39) & 31,084 & 0.05 \\
\hline Machines for special industries, nes (728.49) & 602,013 & 0.92 \\
\hline Machine tools for metal working (736.9) & 175,356 & 0.27 \\
\hline Foundry equipment (737.19) & 15,248 & 0.02 \\
\hline Rolling mill parts (737.29) & 26,549 & 0.04 \\
\hline Refrigerating equipment (741.49) & 117,514 & 0.18 \\
\hline Pumps for liquids (742.9) & 75,179 & 0.11 \\
\hline Centrifuges and filters (743.9) & 287,150 & 0.44 \\
\hline Fork lift trucks (744.19) & 18,878 & 0.03 \\
\hline Lifting and loading machines (744.9) & 447,655 & 0.68 \\
\hline Power hand tools (745.19) & 30,445 & 0.05 \\
\hline Packing machinery (745.23) & 22,085 & 0.03 \\
\hline Non-Electric machinery (749.99) & 162,630 & 0.25 \\
\hline Office and adding machinery (759) & $24,604,494$ & 37.48 \\
\hline Telecommunications equipment (764) & $18,198,727$ & 27.72 \\
\hline Electric power machinery (771.29) & 750,139 & 1.14 \\
\hline Switchgear (772) & $8,477,535$ & 12.91 \\
\hline Domestic electrical equipment (775.79) & 49,726 & 0.08 \\
\hline Electro-thermal appliances (775.89) & 208,005 & 0.32 \\
\hline Electronic components, nes (776.89) & $4,374,729$ & 6.66 \\
\hline Electronic accumulators (778.19) & 73,358 & 0.11 \\
\hline Electric lamps and bulbs (778.29) & 30,756 & 0.05 \\
\hline Electrical machinery, nes (778.89) & 370,171 & 0.56 \\
\hline Motor vehicles and accessories (784) & $1,542,921$ & 2.35 \\
\hline Carriages and cycles (785.39) & 854,227 & 1.30 \\
\hline Trailers and non-motor vehicles (786.89) & 60,100 & 0.09 \\
\hline
\end{tabular}


Table 17. 1 Continued

\begin{tabular}{|l|c|c|}
\hline & \multicolumn{2}{|c|}{ Regional Trade } \\
\cline { 2 - 3 } Component Part Description (SITC Number)* & Value & Share (\%) \\
\hline Railroad equipment and vehicles (791.99) & 12,758 & 0.02 \\
Aircraft and helicopters (792.9) & 426,848 & 0.65 \\
Chairs (821.19) & 54,474 & 0.08 \\
Other furniture parts (821.99) & 166,969 & 0.25 \\
Measuring or drawing machines (874.29) & 119,798 & 0.18 \\
Still cameras, nes (881.19) & 686,945 & 1.05 \\
Cameras under 16mm (881.21) & 31,253 & 0.05 \\
Cameras under 16mm, nes (881.29) & 12,580 & 0.02 \\
Unmounted optical elements (884.11) & 23,517 & 0.04 \\
Clocks and watches (885.29) & 328,587 & 0.50 \\
Umbrellas and canes (899.49) & 38,090 & 0.06 \\
& & \\
ALL ABOVE ITEMS & $65,649,409$ & 100.00 \\
& & \\
MEMO ITEM: EAST ASIAN REGIONAL TRADE & & \\
All Above Parts and Components. & $65,649,409$ & 26.23 \\
All Manufactures Excluding Chemicals & $250,269,408$ & 100.00 \\
\hline
\end{tabular}

*The official description of this item in UN COMTRADE is preceded by the term "Parts of ....". This has been omitted in the table to avoid excessive duplication.

Source: Computations based on UN COMTRADE statistics.

Table 17.1 utilizes the UN SITC Revision 2 trade statistics to examine the composition and relative importance of individual component products in East Asian trade. ${ }^{30}$ The table identifies each product by SITC number, it provides a short description, and also indicates the value and share of each item in all East Asian regional components trade. To help assess the relative importance of East Asian production sharing, the table also compares the value of regional trade in parts and components with that for all manufactured goods exclusive of chemicals. Regional trade in components now accounts for about one-quarter of this exchange.

One interesting point evident from these statistics is that East Asian component trade is concentrated in a relatively few itemis. Four products account for almost 85 percent of regional trade, with parts of office machinery and telecommunications equipment accounting for about two-thirds of this exchange. Production sharing is of major importance in these sectors that are among the fastest growing global exports of the East Asian countries (see Trade Trends 14). An analysis of the underlying individual East Asian country's trade statistics reveals little variation in the relative importance of these products across countries (see Appendix Table A4). A similar high level of product concentration has also been observed in global statistics on components trade except that motor vehicle parts were the largest single traded component product on all world markets (Yeats 2001).

How big is East Asian production sharing? The answer is very big! With regard to the relative importance of parts and components in East Asian trade, the table's memo item shows these goods now account for more than one-quarter of the region's intra-trade in manufactures exclusive of chemicals. The

${ }^{30}$ According to United Nations trade data the United States and Germany were the two largest exporters and importers of components, but Singapore, Hong Kong, Japan, Malaysia, and China ranked among the 10 largest countries participating in this exchange. In 1996, East Asian (including Japan) global trade in parts and components ( $\$ 165$ billion) fell between North America ( $\$ 152$ billion) and OECD Europe (\$239 billion) according to $\mathrm{Ng}$ and Yeats $(1999, \mathrm{p} .10)$ 
magnitude of this exchange, and East Asian countries links in international production sharing, would clearly be positive factors in any regional trade arrangements

\title{
Trade Trends 18
}

\section{The Direction of East Asian Trade in Parts and Components}

\author{
Key Point
}

Japan is an important center or "hub" of production sharing operations in East Asia originating about one-third (\$38.7 billion) of all regional exports of components for assembly. Over 70 percent of Indonesia's regional imports of components originate in Japan, while the corresponding share for Korea, the Philippines and Taiwan exceeds 50 percent. Trade in parts and components plays a key role in several countries strategic trade policy, often serving as a means of penetrating markets for high technology, or high skill products.

Any analysis of East Asian intra-trade in parts and components should examine the geographic pattern of this exchange. Specifically, countries that specialize the export of these goods may be at a competitive disadvantage in further assembly operations, possibly due to the influence of relatively high wage costs. ${ }^{31}$ Similarly, countries that are primarily importers of components may have a competitive advantage in assembly operations, possibly due to a large available pool of low cost labor. These latter countries may be at a comparative disadvantage in the production of some components, particularly those manufactured using capital intensive techniques. As such, the sign and size of the trade balance in parts and components may help indicate the magnitude of the competitive advantage, or disadvantage, of a country in the production of components, or in assembly operations. One further point should be noted. Previous empirical analyses demonstrated the Japan played a central role as a "hub" for production sharing in East Asia in the mid-1990s ( $\mathrm{Ng}$ and Yeats 1999), and was the major "source" of these goods. As such, the country coverage of this section is expanded to permit current analysis of trade in parts and components between Japan and other countries of East Asia.

Table 18.1 provides 2001 statistics on the origins and destinations of East Asian intra-trade in these goods. The top row of the table identifies the countries originating regional exports of components, while the left-most column shows the destinations (that is, the importers) of these shipments. For example, the table indicates Japan exported $\$ 8.3$ billion in parts and components to China, while Singapore's exports to Hong Kong were just under $\$ 2$ billion. Five countries, namely, Brunei, Cambodia, Lao PDR, Mongolia, and Vietnam were excluded from this analysis due to the fact that their participation in this regional activity was relatively unimportant.

The table's middle third shows the share of each country's total imports of components supplied by individual East Asian exporters. As an example, China sourced 43 percent of its imports of components from Japan, and about 13 percent from the Republic of Korea. Similarly, Hong Kong's major supplier of components was China which originated $\$ 13.6$ billion, or 45.5 percent of its total imports. Finally, the lower third of the table shows each exporters regional trade balances (exports minus imports) in terms of values, and expressed as a percentage of total exports. For example, Japan's exports of parts and components to East Asia exceeded its imports by about $\$ 23.5$ billion - the value of this positive balance was about 60 percent of its total exports. Bilateral trade balances can be determined from the appropriate column and row entries in Table 18.1

Four important points are evident in the statistics in Tables 18.1,

${ }^{31}$ For example, in 2001 Japan's regional exports of all exports of parts and components totaled about $\$ 38.7$ billion, which was almost two and one half times the value (\$15.2 billion) of imports of components for further assembly. In contrast, the value of imports of components by a low wage country like Indonesia ( $\$ 2.2$ billion) was 30 percent higher than the corresponding value ( $\$ 1.7$ billion) of its exports. 
- First, although China's exports of parts and components increased by almost $\$ 16$ billion over 1995 to 2001 (to a current value of $\$ 26.8$ billion), Japan largely remains the important center of production sharing operations in East Asia originating about one-third ( $\$ 38.7$ billion) of all regional exports of components. Over 70 percent of Indonesia's regional imports of components originate in Japan, while the corresponding share for Korea, the Philippines and Taiwan exceeds 50 percent (Table 18.1). Only in the unusual cases of Hong Kong and Singapore does China (or Malaysia) surpass. Japan as the major supplier of components. ${ }^{32}$

- Second, although Japan was the third largest East Asian importer of components in 2001 (receiving shipments of $\$ 15.2$ billion) behind Hong Kong (imports of almost $\$ 30$ billion) and Singapore, it still maintained a sizeable regional trade surplus of about $\$ 30$ billion for these goods. In addition to China (which had a positive trade balance of $\$ 7.7$ billion, due largely to its close association with Hong Kong) Indonesia, Korean and Taiwan had a net positive balance for regional trade in components.

- Third, China is the second largest regional importer of parts and components, with trade of $\$ 20$ billion, behind Hong Kong. In consultations with the World Bank in the early 1990s, Chinese authorities indicated these imports had a major strategic role in the country's overall trade policy. Specifically, trade in components was encouraged by governmental policies, such as tariff exemptions, that viewed local assembly of foreign produced components as a means of entering markets for high skill or high technology products that would otherwise be impenetrable. Imports of components were also viewed as a means of improving the foreign competitiveness of other industries by lowering production costs (see Lemoine and Kesenci 2002, or World Bank 1994 for details).

- Fourth, the statistics suggest that countries with relatively low wage costs tend to be major importers of components for further assembly. For example, according to the World Bank (2000a) yearly labor costs per worker in manufacturing ranged from $\$ 1,000$ to $\$ 3,400$ in the Philippines, Malaysia, and Thailand (as opposed to $\$ 32,000$ in Japan), and these three developing countries had deficits in regional parts and components trade. Singapore and Hong Kong, with average annual labor costs of $\$ 21,500$ and $\$ 13,500$ respectively appear, at first, to be outliers as both are relatively high labor cost countries with regional imports of components in excess of their exports.

Why do countries like Singapore and Hong Kong, with their relatively high wage costs, have relatively high imports of parts and components? The answer, in part, is that this is the result of a conscious effort to upgrade the composition of their final exports. Partly as a reaction to the East Asian financial crisis, Singapore and Hong Kong adopted a policy of upgrading exports by encouraging production of high technology products. ${ }^{33}$ This strategy relied on increased imports of parts and components, primarily of

${ }^{32}$ Production sharing between China and Japan has grown rapidly since the mid-1990s. As shown in Table 18.1 Japan now sources about $\$ 5.6$ billion of its total regional imports of components from China (as opposed to $\$ 2.1$ billion in 1996), while China's current imports from Japan ( $\$ 8.3$ billion) are approximately double their 1996 value. See $\mathrm{Ng}$ and Yeats (1999) for statistics on regional trade in parts and components in the mid-1990s.

${ }^{33}$ A recent (17 September 2002) Oxford Analytica report notes. "Since the introduction of market reform policies, the Pearl River Delta (PRD)) transformed its primarily agricultural economy into one of the world's leading export-processing zones. Recent economic development in the PRD has been distinguished by a rapid shift to high-tech industry, the region tops national growth rankings for this sector. In 2001, high-tech manufacturing constituted $24 \%$ of total industrial output, of which information technology (IT) and electronics were the fastest growing sectors. High-tech exports reached $31 \%$ of total exports, worth 22 billion dollars. Brisk growth continued in the first six months of 2002 , spurred by a $24 \%$ year-on-year growth in the production of telecornmunications equipment and a $21 \%$ growth in electrical machinery and equipment." 
Table 18. 1 The Matrix of Intra-Trade and Trade Balances in Parts and Components A.mong East Asian Countries in 2001

Exporter

\begin{tabular}{|c|c|c|c|c|c|c|c|c|c|c|c|}
\hline Partner (Importer) & China & Hong Kong & Indonesia & Korea, Rep. & Malaysia & Philippines & Singapore & Taiwan & Thailand & Japan & $\mathrm{EA} 10^{*}$ \\
\hline & \multicolumn{11}{|c|}{ Value of Exports of Parts and Components (\$ million) } \\
\hline China & 0 & 1,542 & 313 & 2,442 & 1,267 & 342 & 759 & 3,279 & 952 & 8,292 & 19,188 \\
\hline Hong Kong, China & 13,556 & 0 & 97 & 2,038 & 2,070 & 494 & 1,980 & 2,928 & 513 & 6,119 & 29,795 \\
\hline Indonesia & 109 & 13 & 0 & 114 & 40 & 10 & 219 & 64 & 82 & 1,558 & 2,209 \\
\hline Korea, Republic & 1,695 & 230 & 64 & 0 & 330 & 183 & 287 & 754 & 162 & 4,317 & 8,022 \\
\hline Malaysia & 1,394 & 745 & 500 & 748 & 0 & 416 & 1,697 & 1,102 & 687 & 3,610 & 10,899 \\
\hline Philippines & 170 & 502 & 26 & 788 & 259 & 0 & 804 & 523 & 256 & 3,683 & 7,011 \\
\hline Singapore & 1,989 & 808 & 1,426 & 838 & 4,611 & 390 & 0 & 1,118 & 1,623 & 3,890 & 16,693 \\
\hline Taiwan, China & 1,308 & 237 & 42 & 719 & 303 & 202 & 529 & 0 & 97 & 3,502 & 6,939 \\
\hline Thailand & 1,030 & 153 & 139 & 486 & 729 & 625 & 490 & 363 & 0 & 3,714 & 7,729 \\
\hline Japan & 5,587 & 238 & 500 & 1,728 & 1,086 & 1,229 & 766 & 2,866 & 1,230 & 0 & 15,230 \\
\hline ALL THE ABOVE & 26,838 & 4,468 & 3,107 & 9,901 & 10,695 & 3,891 & 7,531 & 12,997 & 5,602 & 38,685 & 123,715 \\
\hline
\end{tabular}

$\begin{array}{lll}0.0 & 8.0 & 1.6\end{array}$

Share of Exporter in Total Imports of the Trading Partner (\%)

$\begin{array}{lcc}\text { Hong Kong, China } & 45.5 & 0.0 \\ \text { Indonesia } & 4.9 & 0.6 \\ \text { Korea, Rep. } & 21.1 & 2.9 \\ \text { Malaysia } & 12.8 & 6.8 \\ \text { Philippines } & 2.4 & 7.2 \\ \text { Singapore } & 11.9 & 4 \\ \text { Taiwan, China } & 18.9 & 3.4 \\ \text { Thailand } & 13.3 & 2 \\ \text { Japan } & 36.7 & 1.6\end{array}$

$\begin{array}{cccc}12.7 & 6.6 & 1.8 & 4 . \\ 6.8 & 6.9 & 1.7 & 6.6 \\ 5.2 & 1.8 & 0.5 & 9.9 \\ 0.0 & 4.1 & 2.3 & 3.6 \\ 6.9 & 0.0 & 3.8 & 15 \\ 11.2 & 3.7 & 0.0 & 11 \\ 5.0 & 27.6 & 2.3 & 0.0 \\ 10.4 & 4.4 & 2.9 & 7.6 \\ 6.3 & 9.4 & 8.1 & 6.3 \\ 11.3 & 7.1 & 8.1 & 5.0\end{array}$

$\begin{array}{cc}4.0 & 17.1 \\ 6.6 & 9.8 \\ 9.9 & 2.9 \\ 3.6 & 9.4 \\ 15.6 & 10.1 \\ 11.5 & 7.5 \\ .0 .0 & 6.7 \\ 7.6 & 0.0 \\ 6.3 & 4.7 \\ 5.0 & 18.8\end{array}$

17.1
9.8
2.9
9.4
10.1
7.5
6.7
0.0
4.7
18.8

5.0
1.7
3.7
2.0
6.3
3.7
9.8
1.4
0.0
8.1

\begin{tabular}{cc|}
\hline $\mathbf{4 3 . 2}$ & 100.0 \\
$\mathbf{2 0 . 5}$ & 100.0 \\
$\mathbf{7 0 . 5}$ & 100.0 \\
$\mathbf{5 3 . 8}$ & 100.0 \\
$\mathbf{3 3 . 1}$ & 100.0 \\
$\mathbf{5 2 . 5}$ & 100.0 \\
$\mathbf{2 3 . 4}$ & 100.0 \\
$\mathbf{5 0 . 5}$ & 100.0 \\
$\mathbf{4 8 . 0}$ & 100.0 \\
$\mathbf{0 . 0}$ & 100.0
\end{tabular}

$\begin{array}{lccc}\text { Value (\$ million) } & 7,650 & -25,327 & 898 \\ \text { Share of exports (\%) } & 28.5 & -566.8 & 28.9\end{array}$

\section{Trade Balance of the Exporter}

\begin{tabular}{cccccccc}
\multicolumn{2}{l}{ Trade Balance of the Exporter } & & \\
1,879 & -204 & $-3,120$ & $-7,736$ & 6,058 & $-2,127$ & 23,455 & - \\
19.0 & -1.9 & -80.2 & -102.7 & 46.6 & -38.0 & 60.6 & --
\end{tabular}

* East Asia only includes 9 countries plus Japan due to the lack of COMTRADE data for Brunei, Cambodia, Lao PDR, Mongolia and Vietnam in 2001.

Source: Computations based on UN COMTRADE Statistics. 
telecommunications equipment and office machinery, for further assembly (see Lemoine and Kesenci 2002). In the case of Hong Kong, this strategy drew on the capabilities of "high technology areas" established within China for the manufacture of technology intensive products. ${ }^{34}$ These areas were intended to be counterparts to silicon valley in California or the route 128 corridor in Massachusetts. ${ }^{35}$

Table 18.2 provides information relevant to this point. The table lists the largest parts and components products imported from China (which was, by far, the largest supplier of these goods), it shows the value and share of each good, and (in parentheses) reports the share of the product in all regional countries imports. As indicated, the unusually high level of Hong Kong's imports of components is largely accounted for by two high technology products, parts of telecommunication equipment and parts of office and adding machinery. These two component groups accounted for over $\$ 10$ billion, or 75 percent, of Hong Kong's 2001 imports from China. Trade in telecommunications equipment, that accounted for $\$ 6.8$ billion or 50 percent of Hong Kong's imports (as opposed to a corresponding share of 32 percent in all regional countries trade) was well above the average levels for imports of these goods in other East Asian countries. ${ }^{36}$

Table 18.2 The 2001 Value and Share of Hong Kong's Major Parts and Components Import Products from China

\begin{tabular}{|l|c|c|}
\hline & \multicolumn{2}{|c|}{ 2001 Imports from China } \\
\cline { 2 - 3 } Component Part Description (SITC Number)* & Value (000) & Share** \\
\hline Telecommunications equipment (764)*** & $6,797,411$ & $50.14(32.40)$ \\
Office and adding machinery (759)*:** & $3,309,430$ & $24.41(33.85)$ \\
Switchgear (772) & $1,788,043$ & $12.19(14.44)$ \\
Electrical power machinery (771.29) & 314,460 & $2.32(1.62)$ \\
Still cameras (881.19)*** & 242,602 & $1.79(1.23)$ \\
Electronic components, nes (776.89)*** & 152,211 & $1.12(7.03)$ \\
Carriages and cycles (785.39) & 146,557 & $1.08(0.99)$ \\
& & \\
All Above Products & $12,750,716$ & $94.06(91.56)$ \\
\hline
\end{tabular}

*The official description of this item in UN COMTRADE is preceded by the term "Parts of ....". This has been omitted in the table to avoid excessive duplication.

** To better help assess implications of the unusual structure of Hong Kong's imports from China, numbers in parentheses show the share of the product in all East Asian countries regional imports.

*** According to UNCTAD (Mayer et. al, 2002) this item is normally manufactured using high skill and high technology production techniques.

${ }^{34}$ Singapore participates in a somewhat more complex economic zone that combines its comparative advantages with those of Malaysia and Indonesia. Specifically, the general objective of the Johor-RiauSingapore growth zone is to bring together semiskilled labor from Malaysia, low cost land and labor from Indonesia, and capital from Singapore.

${ }^{35}$ Yusuf and Evenett (2002) provide a useful discussion of the factors required for the development of these high technology clusters. The city of Shenzhen, which borders Hong Kong, is one such center and has been a growing supplier of parts and components of high technology products. See the web cite Shenzhenwindow.net/20years/hitech.htm for interesting information on the development of this high technology city.

${ }^{36}$ Our analysis of Singapore's imports showed that these same product groups (parts of office machinery and telecommunications equipment) were also largely responsible for what, at first, appeared to be a relatively high level of components imports. In this case, however, the high technology cluster supplying these goods was located in Malaysia. 
Given the special nature of the trade relationship between Hong Kong and China, Table 18.3 examines East Asian trade in parts and components from a somewhat different perspective. The table nets out intra-trade between China and Hong Kong (jointly referred to as Greater China) and analyzes the intratrade of Greater China, Japan, and the East Asian (7) countries as a group. The latter includes Korea, Malaysia, Philippines, Singapore, Taiwan (China), and Thailand.

This revised analytical framework confirms the generally accepted view of (Greater) China as a major importer and specialist in the assembly of components. As indicated, China's 2001 regional imports and exports of components leaves it with a negative trade balance of $\$ 17.6$ billion for these goods. A breakdown of this negative balance shows it to be about the same magnitude for Japan and the East Asia (7) countries. Similarly, Japan's total regional trade surplus of $\$ 29.3$ billion is about evenly distributed between Greater China and East Asia (7). In both cases, the relative size of the negative balances are about 60 percent of Japan's 2001 component exports.

Table 18.3. Trade in Parts and Components Among Greater China (Hong Kong plus China) and Other East Asian Producers in 2001

\begin{tabular}{|c|c|c|c|c|}
\hline & \multicolumn{4}{|c|}{ Exporter } \\
\hline Partner (Importer) & $\begin{array}{l}\text { Greater } \\
\text { China* }\end{array}$ & East Asia $(7)^{* *}$ & Japan & $\begin{array}{c}\text { All East } \\
\text { Asia }\end{array}$ \\
\hline . & \multicolumn{4}{|c|}{ Value of Exports of Parts and Components ( $\$$ million) } \\
\hline Greater China* & - & 19,474 & 14,411 & 33,885 \\
\hline East Asia $(7)^{* *}$ & 10,383 & 24,845 & 24,274 & 59,502 \\
\hline Japan & 5,825 & 9,405 & -- & 15,230 \\
\hline All East Asia & 16,208 & 53,724 & 38,685 & 108,617 \\
\hline & \multicolumn{4}{|c|}{ Share of Exporter in Total Imports of Trading Partner (\%) } \\
\hline Greater China* & -- & 57.4 & 42.6 & 100.0 \\
\hline East Asia $(7)^{* *}$ & 17.4 & 41.8 & 40.8 & 100.0 \\
\hline Japan & 38.2 & 61.8 & -- & 100.0 \\
\hline \multirow{2}{*}{ All East Asia } & 14.9 & 49.5 & 35.6 & 100.0 \\
\hline & \multicolumn{4}{|c|}{ Trade Balance of Exporter ( $\$$ million) } \\
\hline Greater China* & -- & 9,091 & 8,586 & 17,677 \\
\hline East Asia** & $-9,091$ & -- & 14,867 & 5,778 \\
\hline Japan & $-8,586$ & $-14,869$ & -- & $-23,455$ \\
\hline \multirow[t]{2}{*}{ All East Asia } & $-17,677$ & $-5,778$ & 29,280 & -- \\
\hline & \multicolumn{4}{|c|}{ Trade Balance as a Percent of Exports (\%) } \\
\hline Greater China* & -- & 46.6 & 59.6 & 52.2 \\
\hline East Asia** & -87.5 & -- & 61.2 & 9.7 \\
\hline Japan & -147.4 & -158.1 & -- & -154.0 \\
\hline All East Asia & -109.1 & -10.8 & 60.6 & -- \\
\hline
\end{tabular}

* Hong Kong plus China

** Indonesia, Korea, Malaysia, Philippines, Singapore, Taiwan (China), and Thailand.

Source: UN COMTRADE statistics 


\title{
Trade Trends 19
}

East Asian Comparative Advantage in the Production and Assembly of Manufactured Components

\author{
Key Point
}

Production sharing in East Asia may be motivated by several strategic trade policy factors including efforts to upgrade the quality and types of goods exported. In addition, considerations relating to factor proportions theory also affects a country's participation in production sharing. The production of parts and components, which is often a capital intensive operation, generally is undertaken in wealthier economies like Japan or Taiwan (China). These goods may then be exported to lower wage cost countries like Indonesia and Thailand for further assembly, which generally is a labor intensive operation.

Economic theory argues there is a relationship between the factor intensities required for the manufacture of specific goods and the location for their optimal production. Goods that are manufactured using labor intensive techniques should normally be produced in poorer, less developed, countries to capitalize on relatively low wage costs. In contrast, goods that are capital intensive in production should be manufactured in richer developed countries where the cost of capital is relatively low. While factor proportions theory has been verified in tests involving the manufacture of goods (see Lary 1968 or Yeats 1989), it has not been tested rigorously for production sharing assembly operations. However, since assembly operations often involve labor intensive activities one would anticipate a pattern in which capital intensive components, like transistors and other electronic equipment, are produced in richer countries and then sent for assembly to less developed (lower wage cost) locations. Is this expected pattern observed in production sharing in East Asia?

Economists often utilize the concept of "revealed" comparative advantage to identify countries whose factor endowments make it advantageous for them to specialize in the production of a good. The revealed comparative advantage ( $R C A$ ) index for country $i$ in the production of product $j$ has been defined as;

$$
\operatorname{RCA}_{\mathrm{ij}}^{\mathrm{p}}=\left[\mathrm{x}_{\mathrm{ij}} / \mathrm{X}_{\mathrm{j}}\right] \div\left[\mathrm{x}_{\mathrm{wj}} / \mathrm{X}_{\mathrm{w}}\right] \times 100
$$

where $x_{i j}$ and $x_{w j}$ represent the value of $j$ exported by country $i$ and the world, respectively, while $X_{w j}$ and $\mathrm{X}_{\mathrm{w}}$ are world trade in $\mathrm{j}$ and total world trade. The index has a relatively simple interpretation. If its value exceeds unity the country is said to have a comparative advantage in the production of product $\mathrm{j}$. In contrast, if the RCA index is below one the country is at a comparative disadvantage in the good. ${ }^{37}$ However, equation (19.1) must be used with some caution since domestic measures, that have nothing to do with comparative advantage (like local subsidies or foreign trade barriers), can bias the index.

This analysis employs a variant of equation (19.1) developed by $\mathrm{Ng}$ and Yeats (1999) to identify countries that appear to have a comparative advantage in further upstream operations - that is, the assembly of the next step of a manufacturing process. Specifically, the revealed comparative advantage of country $i$ in the assembly of product $j$ is;

$$
\mathrm{RCA}_{\mathrm{ij}}^{\mathrm{a}}=\left[\mathrm{m}_{\mathrm{ij}} / \mathrm{M}_{\mathrm{j}}\right] \div\left[\mathrm{m}_{\mathrm{wj}} / \mathrm{M}_{\mathrm{w}}\right] \times 100
$$

where the m's represent imports, but otherwise correspond to the terms in equation (18.1). The reasoning behind this proposition is relatively straightforward. Parts and components typically have no general end us in themselves, but are exchange for further assembly into a product that does. ${ }^{38}$ Therefore, it follows

${ }^{37}$ Balassa (1965) developed and applied the concept of "revealed" comparative advantage and also made important extensions in Balassa (1977)(1979).

${ }^{38}$ There is one exception when an irnported component is used as a replacement for a failed part in an already assembled good. However, this should have a neutral effect across countries unless failure rates for 
that countries that have above average import shares for components also have a comparative advantage in the assembly operation for these goods.

Appendix Tables A19.1 through A19.3 show 1985, 1995 and 2001 RCA indices calculated using each East Asian country's import statistics. As noted, these data should indicate whether or not the country has a comparative advantage in the assembly of each product. Similarly, Appendix Tables A19.4 through A19.6 show RCA indices computed using export statistics, and indicate whether these countries have a comparative advantage in the production of components. Statistics for Japan are included in these appendices since Trade Trends 18 showed this country plays a major role in East Asian production sharing operations. Comparative advantage indices for the United States are also shown to assist in making informed comparisons.

Table 19.1 provides summary statistics for the 1985, 1995 and 2001 RCA indices reported in the appendix tables. Shown here is the percentage of all 60 component product groups in which each East Asian country had a 1985 or 2001 comparative advantage in the production, or assembly, of components. For example, in 1985 China only had a comparative advantage in the production of less than 7 percent of the 60 component groups, as opposed to approximately 42 percent for these item's assembly operations. By 2001, however, China's comparative advantage in the production of components increased to include one-fifth of the parts and components groups and, in assembly operations, more than one-half of these products

Several noteworthy points are evident in these summary statistics;

- The pattern reflected in the data generally are in line with expectations based on factor proportions theory. Japan, which has the highest unit wage costs in the region, now only has a comparative advantage in the assembly of about one-fifth of the 60 component product groups, which is sharply lower than the results for China, Thailand and Indonesia. China, for example, has a comparative advantage in the assembly of 53 percent of the component product groups, while the corresponding share for Indonesia is ten percentage points higher.

- Exclusive of Japan, the East Asian Countries (taken together) now have a comparative advantage in the assembly of about 44 percent of these component product groups. This is almost two and one half times higher than corresponding statistics on their comparative advantage in production. This pattern is reversed for Japan where the comparative advantage in production operations (56.7 percent of all component product groups) is almost three times higher than in the case of imports for further assembly.

- The comparative advantage of almost all East Asian countries in assembly operations is concentrated in the office machinery and electrical machinery groups (see Appendix Table A19.3). In contrast, there are a few product sectors, like motor vehicle components, where no East Asian country has yet to develop a comparative advantage in assembly operations.

parts in assembled products differed substantially between nations, or there was wide differences in the use of a given finished product across countries. 
Table 19.1 The Percentage of All Parts and Components Products in Which East Asian Countries Have a Comparative Advantage

\begin{tabular}{|c|c|c|c|c|c|c|}
\hline \multirow[b]{2}{*}{ Country } & \multicolumn{3}{|c|}{$\begin{array}{l}\text { Export - Production Operations } \\
(\% \text { of Products with RCAs }>1)^{*}\end{array}$} & \multicolumn{3}{|c|}{$\begin{array}{l}\text { Import - Assembly Operations } \\
(\% \text { of Products with RCAs }>1)^{*}\end{array}$} \\
\hline & 1985 & 1995 & 2001 & 1985 & 1995 & 2001 \\
\hline \multicolumn{7}{|l|}{ East Asia } \\
\hline Brunei & .. & 3.3 & 0.0 & 0.0 & 18.3 & 23.3 \\
\hline Cambodia & .. & 1.7 & 0.0 & 0.0 & 15.0 & 11.7 \\
\hline China & 6.7 & 11.7 & 20.0 & 41.7 & 55.0 & 53.3 \\
\hline Hong Kong & 18.3 & 23.3 & 23.3 & 36.7 & 23.3 & 31.7 \\
\hline Indonesia & 0.0 & 5.0 & 10.0 & 65.0 & 55.0 & 63.3 \\
\hline Japan & 43.3 & 58.3 & 56.7 & 3.3 & 8.3 & 21.7 \\
\hline Korea & 6.7 & 13.3 & 15.0 & 25.0 & 41.7 & 33.3 \\
\hline Lao PDR &.. & 0.0 & 0.0 & & 11.7 & 11.7 \\
\hline Malaysia & 8.3 & 15.0 & 18.3 & 53.3 & 45.0 & 43.3 \\
\hline Mongolia & & 0.0 & 0.0 & . & 21.7 & 11.7 \\
\hline Philippines & 6.7 & 10.0 & 10.0 & 38.3 & 50.0 & 31.7 \\
\hline Singapore & 20.0 & 23.3 & 20.0 & 36.7 & 40.0 & 38.3 \\
\hline Taiwan, China & 20.0 & 31.7 & 28.3 & 13.3 & 35.0 & 31.7 \\
\hline Thailand & 8.3 & 11.7 & 15.0 & 33.3 & 55.0 & 58.3 \\
\hline Vietnam & & 8.3 & 5.0 & .. & 30.0 & 38.3 \\
\hline Average of Above & 13.8 & 20.3 & 21.7 & 34.7 & 40.8 & 40.7 \\
\hline Average Excluding Japan & 10.5 & 16.1 & 17.8 & 38.1 & 44.4 & 42.7 \\
\hline \multicolumn{7}{|l|}{ Comparators ${ }^{* *}$} \\
\hline Mexico & .. & 20.0 & 33.3 & 45.0 & 46.7 & 53.3 \\
\hline Hungary & 10.0 & 31.7 & 25.0 & 71.7 & 53.3 & 46.7 \\
\hline Poland & .. & 30.0 & 41.7 & 51.7 & 48.3 & 61.7 \\
\hline United States & 61.7 & 63.3 & 66.7 & 30.0 & 33.3 & 31.7 \\
\hline
\end{tabular}

* Percentages based on the 60 parts and component products listed in the appendices.

** Comparator countries statistics drawn from Ng and Yeats (1999).

\section{CONCLUSIONS}

Almost without exception this study's findings show that East Asian intra-trade has had a major positive influence on regional cooperation and growth. Since the mid-1980s, East Asian intra-trade has been growing at a rate roughly double that of world trade, and at a rate far higher than the intra-trade of NAFTA or the European Union. Similarly, evidence based on intra-industry trade ratios, or statistics on international production sharing, show economic linkages and the interdependence of East Asian economies have considerably strengthened. Furthermore, the export and import profiles of East Asian countries have been changing in directions that increase complementarity which further increases the potential for intra-regional trade. China's emergence has had a major positive influence on the region. Specifically, China's internal counter-cyclical policies, and its maintenance of a stable exchange rate, are generally viewed as important factors that helped contain the effects of the Asian financial crisis. 
Appendix Table A19.1. The Revealed Comparative Advantage of East Asian Countries in Assembly Operations as Reflected in Their 2001 Import Statistics

\begin{tabular}{|c|c|c|c|c|c|c|c|c|c|c|c|}
\hline Component Product Group* & China & $\begin{array}{l}\text { Hong } \\
\text { Kong }\end{array}$ & Indonesia & $\begin{array}{c}\text { Rep. of } \\
\text { Korea }\end{array}$ & Malaysia & Philippines & Singapore & $\begin{array}{c}\text { Taiwan, } \\
\text { China }\end{array}$ & Thailand & Japan & USA \\
\hline Steam boilers & 2.89 & 0.19 & 1.41 & 0.57 & 5.83 & 0.96 & 0.90 & 1.27 & 0.51 & 0.27 & 1.36 \\
\hline Aircraft engines & 0.43 & 0.45 & 0.20 & 0.86 & 0.82 & 0.10 & 1.59 & 0.60 & 1.13 & 1.64 & 1.29 \\
\hline Outboard Motors & 0.30 & 0.20 & 2.31 & 0.52 & 0.91 & 0.12 & 0.23 & 0.19 & 0.28 & 0.07 & 2.12 \\
\hline Outboard motors, nes & 2.38 & 0.19 & 2.10 & 1.47 & 1.07 & 1.82 & 2.65 & 2.62 & 0.72 & 0.28 & 0.56 \\
\hline Combustion engines, nes & 0.76 & 0.18 & 2.74 & 0.85 & 0.80 & 0.56 & 0.83 & 0.60 & 1.51 & 0.34 & 1.15 \\
\hline Engines and motors, nes & 0.26 & 0.57 & 0.57 & 0.40 & 0.65 & 0.31 & 1.95 & 0.48 & 0.90 & 1.00 & 1.60 \\
\hline Rotating electric motors & 1.99 & 1.23 & 1.19 & 1.17 & 1.09 & 1.90 & 1.26 & 0.80 & 2.48 & 0.80 & 1.20 \\
\hline Water turbines & 4.04 & 0.27 & 0.15 & 0.10 & 0.76 & 3.59 & 0.10 & 0.11 & 0.40 & 0.18 & 0.43 \\
\hline Cultivating equipment & 0.24 & 0.16 & 0.89 & 0.13 & .0 .24 & 0.85 & 0.46 & 0.14 & 0.79 & 0.78 & 0.76 \\
\hline Harvesting machinery & 0.15 & 0.07 & 0.32 & 0.18 & 0.14 & 0.12 & 0.09 & 0.11 & 0.14 & 0.36 & 0.76 \\
\hline Dairy machinery & 0.36 & 0.05 & 1.04 & 0.52 & 0.10 & 0.09 & 0.07 & 0.12 & 0.27 & 0.77 & 0.27 \\
\hline Wine making machinery & 2.14 & 0.27 & 2.02 & 0.07 & 0.78 & 0.28 & 0.14 & 0.35 & 0.35 & 0.36 & 0.28 \\
\hline Agricultural machinery, nes & 0.59 & 0.14 & 2.26 & 0.30 & 0.60 & 1.37 & 0.15 & 0.18 & 1.30 & 0.73 & 0.54 \\
\hline Construction machinery & 0.67 & 0.32 & 1.84 & 0.44 & 2.12 & 1.12 & 3.61 & 0.11 & 1.06 & 0.35 & 0.43 \\
\hline Spinning machinery & 3.94 & 0.48 & 5.82 & 1.31 & 0.70 & 0.61 & 0.36 & 1.97 & 3.09 & 0.52 & 0.52 \\
\hline Knitting machinery & 1.94 & 2.06 & 4.23 & 1.06 & 0.54 & 0.47 & 0.64 & 1.28 & 1.91 & 0.78 & 0.68 \\
\hline Textile machinery, nes & 1.94 & 0.65 & 2.22 & 0.47 & 1.47 & 0.91 & 0.24 & 0.50 & 3.46 & 0.78 & 0.30 \\
\hline Paper making machinery & 1.52 & 0.15 & 1.76 & 0.57 & 0.64 & 0.37 & 0.24 & 0.32 & 1.63 & 0.52 & 0.81 \\
\hline Bookbinding machinery & 0.15 & 0.33 & 0.50 & 0.52 & 0.20 & 0.23 & 0.47 & 0.30 & 0.20 & 0.60 & 1.36 \\
\hline Printing machinery & 1.34 & 0.78 & 1.55 & 1.00 & 0.64 & 0.83 & 0.58 & 0.77 & 0.96 & 1.05 & 0.88 \\
\hline Grain milling machinery & 1.17 & 0.29 & 1.53 & 0.72 & 0.46 & 1.63 & 0.32 & 0.36 & 1.12 & 0.39 & 0.43 \\
\hline Food processing machinery & 0.88 & 0.20 & 1.75 & 0.51 & 0.40 & 0.95 & 0.29 & 0.24 & 1.87 & 0.80 & 0.65 \\
\hline Machines for special industries & 1.06 & 0.67 & 1.63 & 1.00 & 1.91 & 0.97 & 1.72 & 3.00 & 1.11 & 0.95 & 0.79 \\
\hline Mineral working machinery & 1.10 & 0.19 & 3.44 & 0.30 & 1.01 & 0.56 & 0.77 & 0.34 & 0.53 & 0.45 & 0.63 \\
\hline Special industry machines, nes & 1.66 & 0.67 & 1.35 & 2.19 & 2.42 & 1.87 & 1.86 & 2.26 & 1.98 & 0.96 & 0.82 \\
\hline Metalworking machinery & 1.11 & 0.52 & 0.64 & 1.12 & 1.04 & 0.72 & 0.87 & 2.23 & 1.71 & 1.02 & 1.03 \\
\hline Foundry equipment & 1.92 & 0.50 & 1.61 & 0.91 & 0.66 & 0.30 & 0.43 & 1.39 & 1.09 & 0.82 & 1.02 \\
\hline Rolling mill parts & 3.17 & 1.07 & 3.61 & 2.78 & 0.95 & 0.26 & 0.13 & 1.81 & 1.72 & 0.29 & 0.56 \\
\hline Refrigerating equipment & 0.93 & 0.61 & 1.96 & 0.24 & 0.65 & 0.86 & 1.15 & 0.45 & 1.04 & 0.48 & 0.64 \\
\hline Pumps for liquids & 0.85 & 0.24 & 1.24 & 1.21 & 0.58 & 0.44 & 1.29 & 0.60 & 0.86 & 0.43 & 0.86 \\
\hline Centrifuges and filters & 1.46 & 0.49 & 1.07 & 1.29 & 1.17 & 0.70 & 1.21 & 1.06 & 1.71 & 0.75 & 0.83 \\
\hline Fork lift trucks & 0.54 & 0.47 & 0.76 & 0.27 & 0.56 & 4.87 & 0.40 & 0.28 & 4.23 & 0.89 & 0.93 \\
\hline Lifting and loading machines & 1.37 & 0.36 & 2.41 & 0.74 & 0.73 & 0.51 & 1.02 & 0.45 & 0.82 & 0.45 & 0.87 \\
\hline Power hand tools & 0.25 & 0.42 & 1.28 & 0.40 & 1.56 & 1.00 & 0.81 & 0.52 & 0.57 & 0.62 & 1.26 \\
\hline Packing machinery & 0.93 & 0.39 & 1.59 & 0.37 & 0.39 & 0.77 & 0.60 & 0.41 & 1.30 & 0.54 & 0.75 \\
\hline
\end{tabular}


Appendix Table A19.1. Continued

\begin{tabular}{|c|c|c|c|c|c|c|c|c|c|c|c|}
\hline Component Product Group* & China & $\begin{array}{l}\text { Hong } \\
\text { Kong }\end{array}$ & Indonesia & $\begin{array}{l}\text { Rep. of } \\
\text { Korea }\end{array}$ & Malaysia & Philippines & Singapore & $\begin{array}{c}\text { Taiwan, } \\
\text { China }\end{array}$ & Thailand & Japan & USA \\
\hline Non-Electric machinery & 0.92 & 0.52 & 0.79 & 1.20 & 1.13 & 0.68 & 1.30 & 1.67 & 1.30 & 0.64 & 0.77 \\
\hline Office and adding machinery & 1.50 & 2.06 & 0.59 & 0.86 & 2.15 & 2.18 & 3.45 & 1.80 & 2.92 & 1.30 & 1.09 \\
\hline Telecommunications equipment & 1.61 & 1.69 & 1.17 & 0.85 & 1.61 & 1.17 & 1.17 & 0.91 & 1.45 & 0.91 & 1.13 \\
\hline Electric power machinery & 3.87 & 2.85 & 1.98 & 1.25 & 2.58 & 2.57 & 1.91 & 0.86 & 1.72 & 0.90 & 0.75 \\
\hline Switchgear & 1.59 & 1.86 & 1.05 & 1.04 & 2.50 & 2.12 & 2.12 & 1.20 & 1.73 & 0.64 & 0.97 \\
\hline Domestic electrical equipment & 1.75 & 1.04 & 0.29 & 0.52 & 1.81 & 0.12 & 0.48 & 0.23 & 0.30 & 0.79 & 0.85 \\
\hline Electrothermic appliances & 2.85 & 1.56 & 1.40 & 0.30 & 1.59 & 0.22 & 0.32 & 0.48 & 2.75 & 0.77 & 0.53 \\
\hline Electronic components, nes & 2.97 & 2.02 & 1.92 & 3.68 & 14.70 & 10.25 & 2.39 & 4.93 & 5.83 & 0.94 & 0.59 \\
\hline Electronic accumulators & 3.67 & 1.50 & 2.07 & 1.53 & 2.77 & 0.58 & 0.24 & 2.36 & 0.51 & 0.29 & 0.33 \\
\hline Electric lamps and bulbs & 1.79 & 1.13 & 3.45 & 1.09 & 0.43 & 0.43 & 0.84 & 0.77 & 2.46 & 1.08 & 0.63 \\
\hline Electrical machinery, nes & 1.17 & 2.59 & 0.35 & 2.52 & 2.21 & 2.89 & 3.91 & 2.23 & 1.79 & 0.88 & 1.00 \\
\hline Motor vehicles and accessories & 0.67 & 0.11 & 1.04 & 0.44 & 0.44 & 0.44 & 0.18 & 0.38 & 0.99 & 0.41 & 1.14 \\
\hline Carriages and cycles & 0.64 & 1.02 & 9.80 & 0.29 & 0.76 & 1.69 & 0.75 & 2.27 & 1.40 & 0.97 & 0.81 \\
\hline Trailers and non-motor vehicles & 0.19 & 0.18 & 0.65 & 0.13 & 1.02 & 0.30 & 0.34 & 0.15 & 0.28 & 0.39 & 0.39 \\
\hline Railroad equipment & 0.50 & 0.18 & 0.20 & 1.38 & .0 .37 & 0.23 & 0.25 & 0.54 & 0.06 & 0.31 & 1.13 \\
\hline Aircraft and helicopters & 0.34 & 0.30 & 0.33 & 1.21 & 0.28 & 0.30 & 1.23 & 0.74 & 0.68 & 1.31 & 0.77 \\
\hline Chairs & 0.37 & 0.14 & 0.40 & 0.14 & 0.23 & 0.14 & 0.12 & 0.11 & 0.57 & 0.40 & 1.85 \\
\hline Other fumiture parts & 0.14 & 0.53 & 0.23 & 0.24 & 0.35 & 0.30 & 0.44 & 0.33 & 0.16 & 1.12 & 1.18 \\
\hline Measuring or drawing machines & 1.03 & 0.60 & 0.40 & 1.35 & 1.90 & 1.20 & 2.26 & 2.38 & 1.38 & 1.64 & 1.09 \\
\hline Still cameras, nes & 6.55 & $\mathbf{7 . 4 7}$ & 1.58 & 0.48 & 4.39 & 7.10 & 0.54 & 1.03 & 3.97 & 2.52 & 0.47 \\
\hline Cameras under $16 \mathrm{~mm}$ & 0.45 & 1.64 & 0.13 & 0.89 & 0.54 & 0.81 & 2.07 & 0.46 & 1.05 & 1.15 & 2.01 \\
\hline Cameras under $16 \mathrm{~mm}$, nes & 0.49 & 1.34 & 0.24 & 1.89 & 2.68 & 0.71 & 0.78 & 0.92 & 0.75 & 1.61 & 0.59 \\
\hline Unmounted optical elements & 0.25 & 0.60 & 0.48 & 0.39 & 0.24 & 0.06 & 2.69 & 0.58 & 0.37 & 4.49 & 0.76 \\
\hline Clocks and watches & 4.07 & 10.64 & 0.31 & 0.65 & 3.23 & 2.34 & 1.86 & 0.46 & 8.91 & 1.18 & 0.24 \\
\hline Umbrellas and canes & 0.88 & 11.10 & 1.19 & 0.32 & 0.42 & 1.32 & 0.18 & 0.46 & 2.77 & 0.97 & 0.45 \\
\hline MEMO ITEM & & & & & & & & & & & \\
\hline RCA For All Components & 1.25 & 1.18 & 1.14 & 0.86 & 1.58 & 1.32 & 1.52 & 1.04 & 1.63 & 0.84 & 1.06 \\
\hline $\begin{array}{l}\text { No. of Product Groups with } \\
\text { RCAs exceeding unity }\end{array}$ & 32 & 19 & 38 & 20 & 26 & 19 & 23 & 19 & 35 & 13 & 19 \\
\hline
\end{tabular}

- See Table 17.1 for the SITC Revision 2 classification number of each component product group

Source: Computed from United Nations SITC Revision 2 COMTRADE statistics 
Appendix Table A19.2. The Revealed Comparative Advantage of East Asian Countries in Assembly Operations as Reflected in Their 1995 Import Statistics

\begin{tabular}{|c|c|c|c|c|c|c|c|c|c|c|c|}
\hline Component Product Group* & China & $\begin{array}{l}\text { Hong } \\
\text { Kong }\end{array}$ & Indonesia & $\begin{array}{l}\text { Rep. of } \\
\text { Korea }\end{array}$ & Malaysia & Philippines & Singapore & $\begin{array}{c}\text { Taiwan, } \\
\text { China }\end{array}$ & Thailand & Japan & USA \\
\hline Steam boilers & 5.31 & 0.47 & 12.34 & 1.31 & 2.41 & 4.65 & 1.06 & 1.88 & 1.67 & 0.17 & 0.17 \\
\hline Aircraft engines & 0.77 & 0.24 & 0.18 & 1.01 & 0.34 & 0.54 & 1.51 & 0.40 & 0.69 & 2.14 & 1.15 \\
\hline Outboard Motors & 0.04 & 0.88 & 0.58 & 0.46 & 1.04 & 0.15 & 0.83 & 0.33 & 0.29 & 0.10 & 1.59 \\
\hline Outboard motors, nes & 0.95 & 0.20 & 2.64 & 2.00 & 1.86 & 1.73 & 2.48 & 3.10 & 0.61 & 0.35 & 0.81 \\
\hline Combustion engines, nes & 0.98 & 0.40 & 2.56 & 0.93 & 0.79 & 1.08 & 1.00 & 0.93 & 1.55 & 0.36 & 1.21 \\
\hline Engines and motors, nes & 0.29 & 0.34 & 1.14 & 0.84 & 0.84 & 0.64 & 1.17 & 0.45 & 1.24 & 0.70 & 1.63 \\
\hline Rotating electric motors & 2.39 & 1.85 & 2.93 & 1.03 & 2.30 & 0.68 & 0.84 & 1.31 & 3.10 & 0.51 & 0.76 \\
\hline Water turbines & 3.40 & 0.05 & 2.88 & 0.35 & 1.56 & 1.78 & 0.09 & 0.15 & 1.07 & 0.10 & 0.28 \\
\hline Cultivating equipment & 0.05 & 0.08 & 0.67 & 0.51 & 0.25 & 0.56 & 0.22 & 0.52 & 0.67 & 0.27 & 1.05 \\
\hline Harvesting machinery & 0.04 & 0.12 & 0.09 & 0.73 & 0.19 & 0.12 & 0.17 & 0.09 & 0.17 & 0.27 & 0.80 \\
\hline Dairy machinery & 0.35 & 0.17 & 0.41 & 0.51 & 0.19 & 0.12 & 0.31 & 0.32 & 0.29 & 0.55 & 0.32 \\
\hline Wine making machinery & 0.87 & 0.17 & $0: 32$ & 2.23 & 0.20 & 0.65 & 0.54 & 2.04 & 0.28 & 0.29 & 0.55 \\
\hline Agricultural machinery, nes & 3.13 & 0.06 & 1.72 & 0.77 & 0.20 & 0.95 & 0.14 & 0.40 & 1.14 & 0.32 & 0.71 \\
\hline Construction machinery & 1.05 & 0.79 & 1.46 & 0.26 & 1.70 & 1.62 & 2.30 & 0.21 & 0.92 & 0.40 & 0.35 \\
\hline Spinning machinery & 2.08 & 0.46 & 6.68 & 2.42 & 0.52 & 0.83 & 0.41 & 2.49 & 1.50 & 0.44 & 0.82 \\
\hline Knitting machinery & 1.95 & 1.33 & 2.98 & 1.18 & 0.50 & 0.79 & 0.42 & 1.34 & 1.00 & 0.88 & 1.08 \\
\hline Textile machinery, nes & 1.68 & 0.74 & 2.27 & 0.65 & 1.26 & 2.55 & 0.60 & 0.79 & 1.48 & 0.41 & 0.51 \\
\hline Paper making machinery & 1.12 & 0.16 & 7.36 & 1.43 & 0.59 & 1.03 & 0.25 & 0.75 & 2.43 & 0.39 & 0.79 \\
\hline Bookbinding machinery & 0.06 & 0.25 & 0.62 & 0.44 & 0.19 & 0.19 & 0.44 & 0.30 & 0.21 & 0.68 & 1.92 \\
\hline Printing machinery & 0.81 & 0.55 & 0.84 & 0.56 & 0.65 & 0.72 & 0.57 & 0.53 & 0.52 & 0.81 & 0.95 \\
\hline Grain milling machinery & 2.56 & 0.22 & 2.99 & 0.94 & 0.46 & 2.26 & 0.51 & 1.08 & 1.01 & 0.32 & 0.48 \\
\hline Food processing machinery & 1.30 & 0.27 & 0.16 & 0.50 & 0.46 & 0.84 & 0.15 & 0.08 & 2.16 & 0.18 & 0.69 \\
\hline Machines for special industries & 1.61 & 0.76 & 1.85 & 0.62 & 2.21 & 1.30 & 1.13 & 0.58 & 1.21 & 0.48 & 0.88 \\
\hline Mineral working machinery & 3.15 & 0.32 & 4.08 & 0.79 & 0.96 & 1.63 & 0.40 & 0.57 & 1.99 & 0.20 & 0.48 \\
\hline Special industry machines, nes & 2.41 & 0.69 & 1.58 & 2.27 & 1.82 & 1.74 & 1.36 & 1.35 & 1.44 & 0.84 & 0.95 \\
\hline Metalworking machinery & 2.16 & 0.44 & 0.76 & 1.97 & 0.96 & 0.60 & 0.88 & 1.13 & 1.35 & 0.65 & 1.08 \\
\hline Foundry equipment & 6.80 & 0.45 & 1.24 & 2.78 & 2.50 & 0.34 & 0.20 & 3.31 & 1.93 & 0.43 & 1.07 \\
\hline Rolling mill parts & 6.48 & 0.13 & 2.91 & 3.54 & 2.95 & 1.22 & 0.12 & 2.27 & 2.04 & 0.16 & 0.74 \\
\hline Refrigerating equipment & 1.05 & 0.59 & 2.80 & 0.58 & 0.57 & 1.20 & 1.06 & 1.00 & 1.55 & 0.30 & 0.57 \\
\hline Pumps for liquids & 0.67 & 0.28 & 1.55 & 1.61 & 0.42 & 0.66 & 0.90 & 0.55 & 0.90 & 0.44 & 0.81 \\
\hline Centrifuges and filters & 1.43 & 0.55 & 1.69 & 1.31 & 1.13 & 1.01 & 1.25 & 1.18 & 1.53 & 0.49 & 0.85 \\
\hline Fork lift trucks & 1.03 & 0.58 & 0.64 & 2.42 & 9.48 & 2.13 & 0.60 & 0.18 & 0.73 & 0.19 & 0.57 \\
\hline Lifting and loading machines & 1.20 & 0.42 & 1.31 & 1.24 & 1.47 & 0.76 & 1.30 & 0.56 & 1.09 & 0.28 & 0.84 \\
\hline Power hand tools & 0.13 & 0.50 & 0.83 & 0.56 & 1.01 & 0.60 & 1.51 & 0.71 & 0.64 & 0.42 & 1.43 \\
\hline Packing machinery & 1.10 & 0.54 & 0.88 & 0.72 & 0.37 & 1.13 & 0.28 & 0.37 & 0.95 & 0.53 & 0.75 \\
\hline
\end{tabular}


Appendix Table A19.2. Continued

\begin{tabular}{|c|c|c|c|c|c|c|c|c|c|c|c|}
\hline Component Product Group ${ }^{*}$ & China & $\begin{array}{l}\text { Hong } \\
\text { Kong }\end{array}$ & Indonesia & $\begin{array}{l}\text { Rep. of } \\
\text { Korea }\end{array}$ & Malaysia & Philippines & Singapore & $\begin{array}{l}\text { Taiwan, } \\
\text { China } \\
\end{array}$ & Thailand & Japan & USA \\
\hline Non-Electric machinery & 0.59 & 0.49 & 1.04 & 0.94 & 1.10 & 1.21 & 1.00 & 1.73 & 1.39 & 0.50 & 0.86 \\
\hline Office and adding machinery & 0.69 & 1.00 & 0.13 & 0.52 & 1.37 & 1.26 & 2.69 & 1.02 & 1.38 & 0.96 & 1.80 \\
\hline Telecommunications equipment & 2.55 & 1.91 & 1.56 & 0.87 & 2.56 & 1.56 & 1.84 & 0.57 & 1.51 & 0.89 & 1.07 \\
\hline Electric power machinery & 2.61 & 3.46 & 1.16 & 1.28 & 3.25 & 2.21 & 2.00 & 1.47 & 2.11 & 0.67 & 0.56 \\
\hline Switchgear & 1.33 & 1.28 & 1.43 & 1.13 & 2.40 & 1.71 & 2.21 & 1.32 & 1.56 & 0.44 & 1.02 \\
\hline Domestic electrical equipment & 1.41 & 0.57 & 0.33 & 0.22 & 0.83 & 0.34 & 0.53 & 0.33 & 0.37 & 0.50 & 0.78 \\
\hline Electrothermic appliances & 3.75 & 1.52 & 0.19 & 0.64 & 1.82 & 0.88 & 0.35 & 0.36 & 0.88 & 0.43 & 0.52 \\
\hline Electronic components, nes & 1.01 & 0.99 & 0.50 & 4.75 & 11.30 & 8.78 & 3.86 & 4.89 & 2.78 & 0.43 & 1.02 \\
\hline Electronic accumulators & 2.89 & 1.68 & 2.43 & 1.24 & 0.83 & 1.26 & 1.01 & 0.37 & 0.18 & 0.91 & 0.25 \\
\hline Electric lamps and bulbs & 0.56 & 1.17 & 1.94 & 0.78 & 0.52 & 0.86 & 0.50 & 0.44 & 1.43 & 0.56 & 0.92 \\
\hline Electrical machinery, nes & 0.17 & 1.03 & 0.22 & 0.67 & 0.80 & 1.01 & 2.33 & 1.03 & 0.65 & 0.56 & 1.67 \\
\hline Motor vehicles and accessories & 0.66 & 0.13 & 1.45 & 0.56 & 0.51 & 0.65 & 0.27 & 0.65 & 1.32 & 0.29 & 1.24 \\
\hline Carriages and cycles & 0.97 & 1.63 & 5.48 & 0.29 & 1.37 & 1.35 & 1.59 & 2.93 & 3.95 & 0.69 & 0.74 \\
\hline Trailers and non-motor vehicles & 0.51 & 0.14 & 0.44 & 0.19 & 0.68 & 0.18 & 0.46 & 0.37 & 0.62 & 0.32 & 0.40 \\
\hline Railroad equipment & 0.61 & 0.20 & 2.36 & 2.17 & 0.37 & 0.11 & 0.14 & 0.51 & 0.10 & 0.23 & 1.09 \\
\hline Aircraft and helicopters & 0.39 & 0.17 & 0.59 & 1.35 & 0.33 & 0.41 & 0.96 & 1.07 & 0.63 & 0.89 & 0.77 \\
\hline Chairs & 0.10 & 0.07 & 0.75 & 0.13 & 0.42 & 0.17 & 0.12 & 0.23 & 0.38 & 0.44 & 1.76 \\
\hline Other furniture parts & 0.12 & 0.48 & 0.22 & 0.31 & 0.21 & 0.51 & 0.53 & 0.40 & 0.12 . & 1.24 & 0.93 \\
\hline Measuring or drawing machines & 1.02 & 0.58 & 0.34 & 1.35 & 1.63 & 0.49 & 1.20 & 0.94 & 0.79 & 1.44 & 1.04 \\
\hline Still cameras, nes & 3.41 & 4.05 & 1.40 & 2.07 & 6.75 & 12.08 & 0.51 & 3.34 & 3.28 & 2.19 & 0.52 \\
\hline Cameras under $16 \mathrm{~mm}$ & 0.11 & 1.40 & 0.16 & 0.92 & 0.51 & 1.07 & 1.03 & 0.38 & 0.44 & 0.97 & 1.67 \\
\hline Cameras under $16 \mathrm{~mm}$, nes & 0.25 & 0.82 & 0.24 & 1.51 & 1.71 & 1.59 & 0.86 & 0.34 & 0.91 & 0.97 & 0.65 \\
\hline Unmounted optical elements & 0.18 & 0.75 & 0.26 & 0.43 & 0.37 & 0.08 & 0.91 & 0.50 & 0.24 & 1.94 & 0.49 \\
\hline Clocks and watches & 5.65 & 9.19 & 1.16 & 0.81 & 3.42 & 2.85 & 1.45 & 0.52 & 6.12 & 0.91 & 0.21 \\
\hline Umbrellas and canes & 1.05 & 13.47 & 0.88 & 0.21 & 0.75 & 2.93 & 0.34 & 0.96 & 3.85 & 0.62 & 0.44 \\
\hline MEMO ITEM & & & & & & & & & & & \\
\hline RCA For All Components & 1.28 & 0.94 & 1.33 & 0.92 & 1.60 & 1.29 & 1.48 & 0.94 & 1.41 & 0.63 & 1.18 \\
\hline $\begin{array}{l}\text { No. of Product Groups with } \\
\text { RCAs exceeding unity }\end{array}$ & 33 & 14 & 33 & 25 & 27 & 30 & 24 & 21 & 33 & 5 & 20 \\
\hline
\end{tabular}

* See Table 17.1 for the SITC Revision 2 classification number of each component product group

Source: Computed from United Nations SITC Revision 2 COMTRADE statistics 
Appendix Table A19.3. The Revealed Comparative Advantage of East Asian Countries in Assembly Operations as Reflected in Their 1985 Import Statistics

\begin{tabular}{|c|c|c|c|c|c|c|c|c|c|c|c|}
\hline Component Product Group* & China & $\begin{array}{l}\text { Hong } \\
\text { Kong }\end{array}$ & Indonesia & $\begin{array}{c}\text { Rep. of } \\
\text { Korea }\end{array}$ & Malaysia & Philippines & Singapore & $\begin{array}{c}\text { Taiwan, } \\
\text { China }\end{array}$ & Thailand & Japan & USA \\
\hline Steam boilers & 3.47 & 3.61 & 2.22 & 0.98 & 0.30 & 2.03 & 1.55 & 0.17 & 2.17 & 0.00 & 0.34 \\
\hline Aircraft engines & 0.03 & 1.61 & 3.31 & 0.09 & 7.52 & 0.33 & 3.94 & 0.00 & 0.26 & 0.03 & 0.00 \\
\hline Outboard Motors & 0.17 & 1.42 & 1.39 & 0.11 & 2.84 & 0.08 & 0.52 & 0.00 & 0.00 & 0.05 & 1.71 \\
\hline Outboard motors, nes & 0.50 & 0.97 & 1.18 & 12.01 & 1.50 & 0.13 & 1.96 & 0.00 & 0.00 & 0.21 & 0.29 \\
\hline Combustion engines, nes & 0.30 & 0.31 & 1.42 & 0.84 & 1.10 & 0.65 & 1.23 & 0.00 & 2.15 & 0.10 & 1.16 \\
\hline Engines and motors, nes & 0.18 & 0.07 & 1.15 & 1.17 & 0.08 & 0.12 & 0.31 & 0.00 & 0.26 & 1.13 & 1.30 \\
\hline Rotating electric motors & 2.64 & 1.33 & 3.13 & 1.15 & 1.42 & 0.75 & 1.00 & 0.00 & 0.00 & 0.39 & 0.87 \\
\hline Water turbines & 0.52 & 0.01 & 23.11 & 0.26 & 0.62 & 0.64 & 0.11 & 0.00 & 0.04 & 0.11 & 0.61 \\
\hline Cultivating equipment & 0.05 & 0.08 & 0.27 & 0.16 & 0.25 & 0.24 & 0.09 & 0.00 & 2.12 & 0.12 & 0.96 \\
\hline Harvesting machinery & 0.61 & 0.00 & 0.13 & 0.51 & 0.35 & 0.08 & 0.05 & 0.00 & 0.02 & 0.07 & 0.54 \\
\hline Dairy machinery & 0.06 & 0.16 & 3.42 & 0.22 & 0.19 & 0.65 & 0.08 & 0.00 & 0.02 & 0.09 & 0.00 \\
\hline Wine making machinery & 16.61 & 0.00 & 11.18 & 0.17 & 3.29 & 3.31 & 0.25 & 0.00 & 0.51 & 0.09 & 0.00 \\
\hline Agricultural machinery, nes & 0.66 & 0.17 & 0.64 & 0.04 & 0.45 & 0.27 & 0.11 & 0.00 & 0.06 & 0.04 & 0.52 \\
\hline Construction machinery & 1.05 & 0.82 & 13.51 & 0.33 & 4.46 & 0.67 & 3.31 & 0.00 & 2.57 & 0.08 & 0.70 \\
\hline Spinning machinery & 4.89 & 0.87 & 4.13 & 1.79 & 0.40 & 0.90 & 0.29 & 4.04 & 0.01 & 0.29 & 0.76 \\
\hline Knitting machinery & 1.96 & 1.65 & 1.81 & 0.57 & 0.71 & 1.12 & 0.20 & 0.73 & 3.23 & 0.56 & 0.89 \\
\hline Textile machinery, nes & 2.24 & 1.52 & 0.86 & 0.32 & 1.01 & 0.49 & 0.14 & 0.00 & 0.70 & 0.07 & 0.61 \\
\hline Paper making machinery & 1.56 & 0.11 & 1.23 & 0.44 & 17.62 & 0.64 & 0.05 & 0.00 & 2.27 & 0.23 & 1.00 \\
\hline Bookbinding machinery & 0.12 & 0.23 & 0.25 & 0.05 & 0.92 & 0.20 & 0.19 & 0.00 & 0.04 & 0.24 & 1.67 \\
\hline Printing machinery & 0.49 & 0.40 & 0.58 & 0.22 & 0.51 & 0.15 & 0.35 & 0.00 & 0.09 & 0.21 & 1.03 \\
\hline Grain milling machinery & 0.40 & 0.12 & 12.34 & 0.23 & 1.13 & 5.08 & 0.29 & 0.00 & 0.18 & 0.03 & 0.20 \\
\hline Food processing machinery & 1.15 & 0.40 & 3.06 & 0.21 & 0.52 & 3.05 & 0.28 & 0.00 & 2.59 & 0.15 & 0.00 \\
\hline Machines for special industries & 0.57 & 0.49 & 3.59 & 0.38 & 1.17 & 1.59 & 0.62 & 0.00 & 0.00 & 0.21 & 1.15 \\
\hline Mineral working machinery & 0.59 & 0.48 & 2.62 & 0.23 & 2.04 & 1.34 & 0.71 & 0.00 & 0.00 & 0.05 & 0.61 \\
\hline Special industry machines, nes & 2.43 & 0.70 & 6.29 & 0.83 & 3.28 & 7.72 & 0.58 & 0.00 & 2.30 & 0.34 & 0.32 \\
\hline Metal working machine tools & 0.88 & 0.27 & 1.31 & 0.61 & 0.74 & 0.50 & 1.01 & 0.57 & 0.58 & 0.28 & 1.30 \\
\hline Foundry equipment & 9.21 & 0.25 & 3.11 & 0.51 & 1.20 & 1.93 & 0.59 & 0.00 & 2.39 & 0.22 & 0.00 \\
\hline Rolling mill parts & 5.87 & 0.11 & 2.69 & 1.49 & 0.98 & 18.06 & 0.14 & 0.00 & 0.70 & 0.12 & 0.00 \\
\hline Refrigerating equipment & 8.94 & 1.19 & 1.87 & 0.12 & 1.74 & 0.49 & 1.41 & 0.00 & 0.87 & 0.20 & 0.00 \\
\hline Pumps for liquids & 0.76 & 0.29 & 5.18 & 0.75 & 0.83 & 1.19 & 1.27 & 0.00 & 1.01 & 0.30 & 0.72 \\
\hline Centrifuges and filters & 0.68 & 0.45 & 1.10 & 0.65 & 1.04 & 1.20 & 1.25 & 0.00 & 1.82 & 0.77 & 0.01 \\
\hline Fork lift trucks & 0.33 & 0.20 & 0.28 & 0.63 & 0.48 & 1.11 & 0.27 & 0.43 & 0.11 & 0.03 & 0.86 \\
\hline Lifting and loading machines & 1.34 & 1.80 & 1.77 & 0.72 & 1.30 & 0.86 & 0.86 & 0.00 & 0.00 & 0.25 & 0.86 \\
\hline Power hand tools & 0.15 & 0.14 & 8.06 & 0.22 & 2.06 & 0.51 & 0.68 & 0.00 & 0.19 & 0.18 & 0.70 \\
\hline Packing machinery & 0.77 & 0.46 & 0.68 & 0.47 & 0.77 & 1.56 & 0.30 & 0.00 & 0.51 & 0.18 & 0.31 \\
\hline
\end{tabular}


Appendix Table A19.3. Continued

\begin{tabular}{|c|c|c|c|c|c|c|c|c|c|c|c|}
\hline Component Product Group* & China & $\begin{array}{l}\text { Hong } \\
\text { Kong }\end{array}$ & Indonesia & $\begin{array}{c}\text { Rep. of } \\
\text { Korea }\end{array}$ & Malaysia & Philippines & Singapore & $\begin{array}{c}\text { Taiwan, } \\
\text { China }\end{array}$ & Thailand & Japan & USA \\
\hline Non-Electric machinery, nes & $0 . \overline{43}$ & 0.31 & 1.12 & 0.89 & 1.64 & 1.31 & 0.78 & 0.78 & 0.50 & 0.32 & 0.23 \\
\hline Office and adding machinery & 0.45 & 1.38 & 0.19 & 0.40 & 0.37 & 0.12 & 1.60 & 0.76 & 1.00 & 0.36 & 1.38 \\
\hline Telecommunications equipment & 2.17 & 1.79 & 1.16 & 1.37 & 2.07 & 0.59 & 1.36 & 1.14 & 1.70 & 0.27 & 1.75 \\
\hline Switchgear & 0.57 & 1.17 & 1.33 & 1.32 & 2.21 & 0.70 & 2.07 & 1.88 & 3.28 & 0.40 & 0.79 \\
\hline Domestic electrical equipment & 1.38 & 3.91 & 0.87 & 0.07 & 0.61 & 0.40 & 0.28 & 0.00 & 1.18 & 0.16 & 0.75 \\
\hline Electrothermic appliances & 0.31 & 2.62 & 0.23 & 0.00 & 1.26 & 0.16 & 2.59 & 0.00 & 0.58 & 0.03 & 1.99 \\
\hline Electronic components, nes & 0.49 & 1.78 & 0.82 & 9.48 & 32.70 & 11.23 & 8.32 & 0.00 & 0.02 & 0.09 & 1.19 \\
\hline Electric lamps and bulbs & 0.15 & 0.63 & 2.68 & 1.77 & 0.59 & 2.02 & 0.08 & 0.31 & 1.42 & 0.08 & 0.00 \\
\hline Electrical machinery, nes & 2.37 & 2.33 & 4.21 & 2.46 & 0.29 & 10.08 & 0.01 & 2.42 & 2.44 & 0.41 & 0.00 \\
\hline Motor vehicles and accessories & 1.80 & 0.19 & 0.41 & 0.23 & 0.24 & 0.19 & 0.24 & 0.34 & 1.08 & 0.06 & 1.25 \\
\hline Carriages and cycles & 1.39 & 0.57 & 3.65 & 0.45 & 1.22 & 0.50 & 0.59 & 3.98 & 4.37 & 0.13 & 1.27 \\
\hline Trailers and non-motor vehicles & 0.10 & 0.05 & 0.14 & 0.10 & 1.10 & 0.05 & 0.32 & 0.51 & 0.36 & 0.02 & 0.00 \\
\hline Railroad equipment & 2.09 & 0.64 & 0.90 & 0.58 & 0.29 & 0.60 & 0.05 & 0.32 & 0.87 & 0.12 & 1.14 \\
\hline Aircraft and helicopters & 1.09 & 0.47 & 1.58 & 1.11 & 0.71 & 0.71 & 1.41 & 0.07 & 0.20 & 0.51 & 1.13 \\
\hline Chairs & 0.01 & 0.09 & 0.38 & 0.34 & 0.54 & 0.05 & 0.54 & 0.00 & 0.28 & 0.49 & 0.00 \\
\hline Other furniture parts & 0.26 & 1.22 & 0.31 & 0.58 & 0.61 & 0.02 & 1.01 & 0.15 & 0.00 & 0.54 & 0.00 \\
\hline Measuring-drawing machines & 0.81 & 0.10 & 7.12 & 0.71 & 1.99 & 0.22 & 0.42 & 0.00 & 0.90 & 0.43 & 0.00 \\
\hline Cameras under $16 \mathrm{~mm}$ & 0.44 & 0.02 & 1.52 & 0.05 & 1.36 & 0.04 & 4.65 & 0.00 & 0.00 & 0.00 & 1.20 \\
\hline Cameras under $16 \mathrm{~mm}$, nes & 0.54 & 1.25 & 0.97 & 0.32 & 0.92 & 0.19 & 0.81 & 0.00 & 0.11 & 0.44 & 0.65 \\
\hline Unmounted optical elements & 0.16 & 2.01 & 0.09 & 0.69 & 0.62 & 0.07 & 1.14 & 0.68 & 0.45 & 0.92 & 1.21 \\
\hline Clocks and watches & 25.82 & 26.75 & 0.13 & 6.33 & 2.10 & 1.86 & 1.88 & 1.72 & 5.38 & 0.21 & 0.25 \\
\hline Umbrellas and canes & 2.99 & 7.03 & 1.95 & 2.05 & 3.13 & 3.19 & 2.79 & 0.03 & 7.00 & 1.31 & 0.46 \\
\hline MEMO ITEM & & & & & & & & & & & \\
\hline RCA For All Components & 1.41 & 1.01 & 1.42 & 1.04 & 2.12 & 0.95 & 1.26 & 0.66 & 1.36 & 0.26 & 1.17 \\
\hline $\begin{array}{l}\text { No. of Product Groups with } \\
\text { RCAs exceeding unity }\end{array}$ & 25 & 22 & 39 & 15 & 32 & 23 & 22 & 8 & 20 & 2 & $18^{\circ}$ \\
\hline
\end{tabular}

* See Table 17.1 for the SITC Revision 2 classification number of each component product group

Source: Computed from United Nations SITC Revision 2 COMTRADE statistics 
Appendix Table A19.4. The Revealed Comparative Advantage of East Asian Countries in Production of Components as Reflected in 2001 Export Statistics

\begin{tabular}{|c|c|c|c|c|c|c|c|c|c|c|c|}
\hline Component Product Group* & China & $\begin{array}{l}\text { Hong } \\
\text { Kong }\end{array}$ & Indonesia & $\begin{array}{c}\text { Rep. of } \\
\text { Korea }\end{array}$ & Malaysia & Philippines & Singapore & $\begin{array}{l}\text { Tạiwan, } \\
\text { China }\end{array}$ & Thailand & Japan & USA \\
\hline Steam boilers & 0.22 & 0.01 & 1.24 & 6.68 & 0.16 & 0.40 & 0.16 & 0.14 & 1.32 & 0.68 & 0.95 \\
\hline Aircraft engines & 0.03 & 0.12 & 0.01 & 0.19 & 0.16 & 0.38 & 1.17 & 0.06 & 0.03 & 1.97 & 4.39 \\
\hline Outboard Motors & 0.02 & 0.09 & 0.00 & 0.01 & 0.05 & 0.00 & 0.01 & 0.00 & 0.10 & 9.71 & 1.50 \\
\hline Combustion engines, nes & 0.15 & 0.04 & 0.13 & 0.27 & 0.04 & 0.10 & 0.23 & 0.24 & 0.30 & 2.31 & 1.47 \\
\hline Engines and motors, nes & 0.11 & 0.24 & 0.05 & 0.35 & 0.07 & 0.02 & 0.84 & 0.10 & 0.20 & 0.65 & 3.35 \\
\hline Rotating electric motors & 0.79 & 0.65 & 0.34 & 0.88 & 0.34 & 0.65 & 0.76 & 1.14 & 0.78 & 1.98 & 1.18 \\
\hline Water turbines & 0.91 & 0.01 & 0.02 & 0.90 & 0.01 & 0.00 & 0.21 & 0.06 & 0.02 & 1.08 & 0.72 \\
\hline Harvesting machinery & 0.27 & 0.05 & 0.02 & 0.16 & 0.03 & 0.02 & 0.06 & 0.56 & 0.01 & 0.40 & 1.69 \\
\hline Dairy machinery & 0.03 & 0.08 & 0.02 & 0.00 & 0.00 & 0.03 & 0.20 & 0.09 & 0.00 & 0.03 & 0.80 \\
\hline Wine making machinery & 0.26 & 0.11 & 0.00 & 0.10 & 0.50 & 0.08 & 0.20 & 0.52 & 0.08 & 0.11 & 0.83 \\
\hline Agricultural machinery, nes & 0.49 & 0.29 & 0.01 & 0.10 & 0.14 & 0.01 & 0.24 & 0.22 & 0.19 & 0.05 & 1.35 \\
\hline Construction machinery & 0.18 & 0.09 & 0.07 & 0.21 & 0.31 & 0.09 & 2.11 & 0.02 & 0.19 & 0.25 & 3.13 \\
\hline Spinning machinery & 0.34 & 0.12 & 0.17 & 0.40 & 0.07 & 0.00 & 0.73 & 0.82 & 0.05 & 1.60 & 0.43 \\
\hline Knitting machinery & 0.23 & 0.38 & 0.14 & 0.57 & 0.08 & 0.01 & 0.28 & 0.93 & 0.09 & 1.56 & 0.26 \\
\hline Textile machinery, nes & 0.73 & 0.48 & 0.06 & 1.58 & 0.05 & 0.18 & 0.18 & 0.57 & 0.27 & 0.51 & 0.58 \\
\hline Paper making machinery & 0.06 & 0.02 & 0.12 & 0.26 & 0.02 & 0.01 & 0.14 & 0.33 & 0.07 & 0.43 & 1.05 \\
\hline Bookbinding machinery & 0.04 & 0.12 & 0.00 & 0.04 & 0.02 & 0.00 & 0.18 & 0.15 & 0.00 & 0.31 & 1.35 \\
\hline Grain milling machinery & 0.44 & 0.02 & 0.27 & 0.06 & 0.26 & 0.01 & 0.36 & 0.72 & 0.61 & 0.66 & 0.82 \\
\hline Food processing machinery & 0.07 & 0.09 & 0.01 & 0.07 & 0.03 & 0.04 & 0.16 & 0.21 & 0.06 & 0.30 & 1.30 \\
\hline Machines for special industries & 0.26 & 0.20 & 0.01 & 0.48 & 0.23 & 0.02 & 0.39 & 1.46 & 0.19 & 1.80 & 1.24 \\
\hline Mineral working machinery & 0.34 & 0.07 & 0.28 & 0.48 & 0.59 & 0.05 & 0.29 & 0.23 & 0.21 & 0.25 & 1.13 \\
\hline Special industry machines, nes & 0.20 & 0.64 & 0.16 & 0.55 & 0.44 & 0.13 & 0.81 & 0.59 & 0.28 & 2.09 & 1.68 \\
\hline Metal working machine tools & 0.24 & 0.16 & 0.01 & 0.57 & 0.15 & 0.12 & 0.30 & 1.10 & 0.28 & 2.52 & 1.39 \\
\hline Foundry equipment & 0.19 & 0.07 & 0.00 & 1.32 & 0.09 & 0.01 & 0.11 & 0.35 & 0.20 & 1.81 & 0.64 \\
\hline Rolling mill parts & 0.16 & 0.04 & 0.03 & 0.56 & 0.06 & 0.05 & 0.08 & 0.21 & 0.07 & 1.79 & 0.66 \\
\hline Refrigerating equipment & 0.50 & 0.22 & 1.29 & 0.92 & 0.48 & 0.41 & 0.64 & 0.39 & 0.64 & 0.84 & 1.38 \\
\hline Pumps for liquids & 0.45 & 0.11 & 0.13 & 0.35 & 0.10 & 0.11 & 0.66 & 0.47 & 0.87 & 1.07 & 1.77 \\
\hline Centrifuges and filters & 0.29 & 0.34 & 0.12 & 0.43 & 0.17 & 0.20 & 0.47 & 0.59 & 0.33 & 1.65 & 1.75 \\
\hline Fork iift trucks & 0.20 & 21.15 & 0.00 & 0.25 & 0.09 & 0.02 & 2.24 & 0.27 & 2.10 & 4.11 & 0.90 \\
\hline Lifting and loading machines & 0.31 & 0.10 & 0.27 & 0.85 & 0.18 & 0.11 & 0.51 & 0.20 & 0.14 & 1.43 & 1.09 \\
\hline Power hand tools & 0.56 & 0.16 & 0.15 & 0.20 & 0.09 & 0.02 & 0.20 & 1.84 & 0.04 & 1.30 & 2.36 \\
\hline Packing machinery & 0.12 & 0.06 & 0.02 & 0.07 & 0.09 & 0.04 & 0.24 & 0.24 & 0.10 & 0.39 & 0.88 \\
\hline
\end{tabular}


Appendix Table A19.4. Continued

\begin{tabular}{|c|c|c|c|c|c|c|c|c|c|c|c|}
\hline Component Product Group* & China & $\begin{array}{l}\text { Hong } \\
\text { Kong }\end{array}$ & Indonesia & $\begin{array}{c}\text { Rep. of } \\
\text { Korea }\end{array}$ & Malaysia & Philippines & Singapore & $\begin{array}{c}\text { Taiwan, } \\
\text { China }\end{array}$ & Thailand & Japan & USA \\
\hline Non-Electric machinery & 0.19 & 0.18 & 0.19 & 0.50 & 0.29 & 0.29 & 1.16 & 0.61 & 0.25 & 1.36 & 1.72 \\
\hline Office and adding machinery & 1.74 & 2.23 & 0.47 & 1.18 & 4.22 & 3.39 & 3.87 & 3.82 & 2.30 & 1.72 & 1.17 \\
\hline Telecommunications equipment & 1.68 & 1.49 & 0.41 & 2.70 & 2.01 & 1.02 & 1.31 & 1.28 & 1.07 & 1.10 & 1.19 \\
\hline Electric power machinery & 1.72 & 2.30 & 3.05 & 1.94 & 1.17 & 0.84 & 0.95 & 2.27 & 0.96 & 1.80 & 1.19 \\
\hline Switchgear & 1.08 & 2.07 & 0.59 & 0.76 & 0.96 & 0.93 & 1.65 & 2.33 & 0.82 & 1.86 & 1.52 \\
\hline Domestic electrical equipment & 2.17 & 0.97 & 0.08 & 0.44 & 0.39 & 0.01 & 0.20 & 0.94 & 0.43 & 0.33 & 1.15 \\
\hline Electrothermic appliances & 1.97 & 1.86 & 0.58 & 3.27 & 0.54 & 0.10 & 1.13 & 1.07 & 0.58 & 0.81 & 0.66 \\
\hline Electronic components, nes & 0.27 & 1.06 & 0.23 & 1.58 & 1.25 & 2.38 & 2.92 & 1.92 & 0.88 & 3.01 & 2.83 \\
\hline Electronic accumulators & 0.64 & 2.71 & 0.24 & 0.26 & 3.14 & 1.04 & 0.30 & 1.01 & 0.43 & 3.09 & 1.40 \\
\hline Electric lamps and bulbs & 1.29 & 0.97 & 0.10 & 0.59 & 0.07 & 0.31 & 0.26 & 0.85 & 0.09 & 1.02 & 1.30 \\
\hline Electrical machinery, nes & 0.68 & 1.99 & 0.14 & 0.51 & 0.62 & 1.53 & 1.87 & i.4i & $\mathbf{i . 2 4}$ & $2 . \overline{9} 9$ & 2.50 \\
\hline Motor vehicles and accessories & 0.11 & 0.02 & 0.14 & 0.38 & 0.06 & 0.29 & 0.06 & 0.38 & 0.30 & 1.64 & 1.60 \\
\hline Carriages and cycles & 2.06 & 0.80 & 0.58 & 0.26 & 1.59 & 0.30 & 1.27 & 5.88 & 1.84 & 3.54 & 0.42 \\
\hline Trailers and non-motor vehicles & 0.60 & 0.09 & 0.05 & 0.54 & 0.45 & 0.01 & 0.10 & 0.58 & 0.06 & 0.03 & 0.88 \\
\hline Railroad equipment & 0.13 & 0.02 & 0.02 & 0.13 & 0.01 & 0.00 & 0.01 & 0.02 & 0.02 & 0.88 & 1.41 \\
\hline Aircraft and helicopters & 0.05 & 0.17 & 0.03 & 0.30 & 0.02 & 0.14 & 0.39 & 0.07 & 0.05 & 0.70 & 2.20 \\
\hline Chairs & 0.39 & 0.05 & 0.19 & 0.19 & 0.16 & 0.27 & 0.04 & 0.33 & 0.71 & 0.26 & 1.96 \\
\hline Other furniture parts & 2.11 & 0.71 & 3.07 & 0.23 & 1.05 & 2.44 & 0.11 & 1.41 & 0.79 & 0.05 & 0.56 \\
\hline Measuring or drawing machines & 0.17 & 0.73 & 1.48 & 0.30 & 0.65 & 0.50 & 0.84 & 0.45 & 0.47 & 1.21 & 2.76 \\
\hline Still cameras, nes & 2.70 & 5.42 & 0.31 & 0.60 & 1.65 & 0.77 & 0.81 & 5.27 & 6.79 & 4.68 & 0.29 \\
\hline Cameras under $16 \mathrm{~mm}$ & 0.21 & 0.83 & 0.04 & 0.18 & 2.85 & 0.04 & 0.64 & 1.00 & 0.23 & 2.10 & 1.84 \\
\hline Cameras under $16 \mathrm{~mm}$, nes & 0.24 & 2.63 & 0.07 & 0.17 & 3.83 & 0.06 & 0.56 & 0.50 & 0.19 & 1.49 & 1.88 \\
\hline Unmounted optical elements & 0.15 & 1.03 & 8.37 & 0.25 & 0.06 & 0.28 & 0.54 & 0.20 & 1.14 & 0.19 & 2.74 \\
\hline Clocks and watches & 1.50 & 8.37 & 0.04 & 0.39 & 1.36 & 0.60 & 1.64 & 0.96 & 4.89 & 4.90 & 0.15 \\
\hline Umbrellas and canes & 7.05 & 4.62 & 0.72 & 0.11 & 0.01 & 0.02 & 0.27 & 6.57 & 0.17 & 0.11 & 0.05 \\
\hline MEMO ITEM & & & & & & & & & & & \\
\hline RCA For All Components & 0.96 & 1.12 & 0.38 & 1.19 & 1.43 & 1.11 & 1.40 & 1.50 & 0.94 & 1.51 & 1.51 \\
\hline $\begin{array}{l}\text { No. of Product Groups with } \\
\text { RCAs exceeding unity }\end{array}$ & 12 & 14 & 6 & 9 & 11 & 6 & 12 & 17 & 9 & 34 & 40 \\
\hline
\end{tabular}

* See Table 17.1 for the SITC Revision 2 classification number of each component product group

Source: Computed from United Nations SITC Revision 2 COMTRADE statistics 
Appendix Table A19.5. The Revealed Comparative Advantage of East Asian Countries in Production of Components as Reflected in 1995 Export Statistics

\begin{tabular}{|c|c|c|c|c|c|c|c|c|c|c|c|}
\hline Component Product Group* & China & $\begin{array}{l}\text { Hong } \\
\text { Kong }\end{array}$ & Indonesia & $\begin{array}{l}\text { Rep. of } \\
\text { Korea }\end{array}$ & Malaysia & Philippines & Singapore & $\begin{array}{l}\text { Taiwan, } \\
\text { China }\end{array}$ & Thailand & Japan & USA \\
\hline Steam boilers & 0.12 & 0.13 & 0.02 & 0.33 & 0.14 & 3.12 & 0.52 & 0.18 & 0.00 & 1.74 & 1.05 \\
\hline Aircraft engines & 0.09 & 0.02 & 0.00 & 0.03 & 0.02 & 0.01 & 0.41 & 0.10 & 0.01 & 1.18 & 4.30 \\
\hline Outboard Motors & 0.01 & 0.62 & 0.01 & 0.01 & 0.00 & 0.00 & 0.03 & 0.02 & 0.00 & 6.30 & 2.13 \\
\hline Outboard motors, nes & 0.07 & 0.11 & 0.00 & 1.89 & 0.03 & 0.00 & 0.25 & 0.01 & 0.01 & 2.38 & 1.34 \\
\hline Combustion engines, nes & 0.10 & 0.14 & 0.06 & 0.23 & 0.03 & 0.03 & 0.28 & 0.48 & 0.14 & 2.43 & 1.31 \\
\hline Engines and motors, nes & 0.04 & 0.19 & 0.07 & 0.19 & 0.05 & 0.27 & 0.72 & 0.04 & 0.39 & 0.34 & 3.19 \\
\hline Rotating electric motors & 0.57 & 0.86 & 0.16 & 0.46 & 0.87 & 0.10 & 1.20 & 1.91 & 0.42 & 2.47 & 1.05 \\
\hline Water turbines & 0.13 & 0.01 & 0.00 & 0.18 & 0.01 & 0.00 & 0.59 & 0.03 & 0.00 & 1.26 & 1.04 \\
\hline Cultivating equipment & 0.30 & 0.04 & 0.01 & 0.34 & 0.01 & 0.01 & 0.03 & 0.10 & 0.02 & 0.20 & 0.68 \\
\hline Harvesting machinery & 0.12 & 0.02 & 0.01 & 0.09 & 0.01 & 0.00 & 0.03 & 0.48 & 0.01 & 0.71 & 1.48 \\
\hline Dairy machinery & 0.01 & 0.01 & 0.00 & 0.03 & 0.00 & 0.00 & 0.05 & 0.09 & 0.02 & 0.06 & 0.57 \\
\hline Wine making machinery & 0.43 & 0.48 & 0.00 & 0.10 & 0.07 & 0.00 & 0.22 & 2.02 & 0.28 & 0.19 & 1.04 \\
\hline Agricultural machinery, nes & 0.27 & 0.05 & 0.00 & 0.07 & 0.06 & 0.00 & 0.11 & 0.38 & 0.15 & 0.08 & 1.42 \\
\hline Construction machinery & 0.08 & 0.31 & 0.02 & 0.27 & 0.77 & 0.33 & 2.53 & 0.04 & 0.16 & 0.43 & 2.78 \\
\hline Spinning machinery & 0.11 & 0.17 & 0.05 & 0.63 & 0.04 & 0.00 & 0.50 & 0.54 & 0.04 & 1.62 & 0.42 \\
\hline Knitting machinery & 0.20 & 0.42 & 0.02 & 0.77 & 0.03 & 0.00 & 0.10 & 0.83 & 0.05 & 1.12 & 0.25 \\
\hline Textile machinery, nes & 0.32 & 0.62 & 0.02 & 1.24 & 0.14 & 0.31 & 0.89 & 0.65 & 0.09 & 1.03 & 0.61 \\
\hline Paper making machinery & 0.05 & 0.07 & 0.11 & 0.12 & 0.06 & 0.04 & 0.15 & 0.40 & 0.25 & 0.83 & 0.93 \\
\hline Bookbinding machinery & 0.02 & 0.07 & 0.00 & 0.02 & 0.00 & 0.00 & 0.05 & 0.25 & 0.01 & 0.23 & 0.56 \\
\hline Printing machinery & 0.07 & 0.22 & 0.01 & 0.13 & 0.04 & 0.04 & 0.27 & 0.25 & 0.03 & 0.74 & 1.19 \\
\hline Grain milling machinery & 0.42 & 0.14 & 0.44 & 0.09 & 0.32 & 0.00 & 1.99 & 0.56 & 0.51 & 0.37 & 0.72 \\
\hline Food processing machinery & 0.10 & 2.49 & 0.08 & 0.17 & 0.13 & 0.17 & 1.41 & 1.53 & 0.13 & 0.44 & 0.81 \\
\hline Machines for special industries & 0.10 & 0.22 & 0.02 & 0.50 & 0.07 & 0.01 & 0.27 & 1.21 & 0.06 & 1.22 & 0.79 \\
\hline Mineral working machinery & 0.22 & 0.09 & 0.01 & 0.36 & 0.28 & 0.33 & 0.15 & 0.17 & 0.24 & 0.39 & 1.20 \\
\hline Special industry machines, nes & 0.13 & 0.61 & 0.02 & 0.28 & 0.19 & 0.05 & 0.75 & 0.52 & 0.11 & 1.92 & 1.60 \\
\hline Metal working machine tools & 0.24 & 0.22 & 0.03 & 0.40 & 0.27 & 0.24 & 0.30 & 0.92 & 0.32 & 1.70 & 1.21 \\
\hline Foundry equipment & 0.17 & 0.08 & 0.01 & 0.97 & 0.02 & 0.04 & 0.07 & 0.33 & 0.06 & 1.10 & 0.64 \\
\hline Rolling mill parts & 0.17 & 0.05 & 0.02 & 0.39 & 0.04 & 0.00 & 0.04 & 0.21 & 0.07 & 1.96 & 0.64 \\
\hline Refrigerating equipment & 0.16 & 0.26 & 0.95 & 0.77 & 0.40 & 0.04 & 0.26 & 0.40 & 0.85 & 1.00 & 1.12 \\
\hline Pumps for liquids & 0.12 & 0.13 & 0.00 & 0.18 & 0.08 & 0.10 & 0.33 & 0.33 & 0.10 & 0.91 & 1.51 \\
\hline Centrifuges and filters & 0.27 & 0.36 & 0.04 & 0.29 & 0.29 & 0.23 & 0.59 & 0.86 & 0.20 & 1.27 & 1.56 \\
\hline Fork lift trucks & 0.08 & 0.10 & 0.03 & 0.37 & 0.34 & 0.05 & 0.11 & 0.25 & 0.01 & 1.68 & 2.42 \\
\hline Lifting and loading machines & 0.15 & 0.11 & 0.26 & 0.56 & 0.13 & 0.08 & 0.40 & 0.17 & 0.10 & 1.58 & 1.01 \\
\hline Power hand tools & 0.18 & 0.12 & 0.13 & $\cdot 0.14$ & 0.03 & 0.01 & 0.16 & 1.13 & 0.03 & 1.35 & 1.85 \\
\hline Packing machinery & 0.04 & 0.21 & 0.00 & 0.09 & 0.01 & 0.10 & 0.16 & 0.18 & 0.10 & 0.34 & 0.88 \\
\hline
\end{tabular}


Appendix Table A19.5. Continued

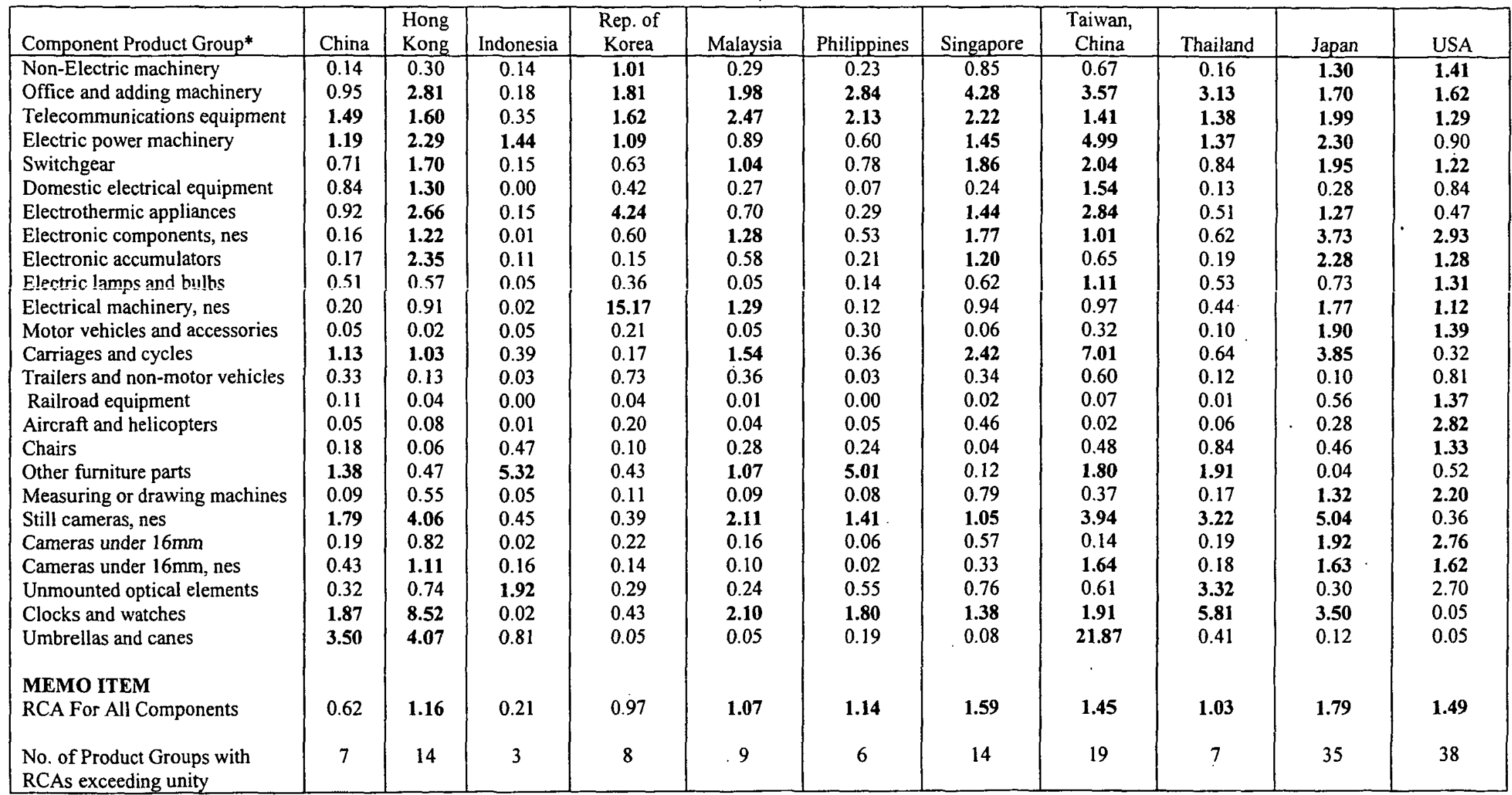

* See Table 17.1 for the SITC Revision 2 classification number of each component product group

Source: Computed from United Nations SITC Revision 2 COMTRADE statistics 
Appendix Table A 19.6. The Revealed Comparative Advantage of East Asian Countries in Production of Components as Reflected in 1985 Export Statistics

\begin{tabular}{|c|c|c|c|c|c|c|c|c|c|c|c|}
\hline Component Product Group ${ }^{*}$ & China & $\begin{array}{l}\text { Hong } \\
\text { Kong }\end{array}$ & Indonesia & $\begin{array}{l}\text { Rep. of } \\
\text { Korea }\end{array}$ & Malaysia & Philippines & Singapore & $\begin{array}{l}\text { Taiwan, } \\
\text { China }\end{array}$ & Thailand & Japan & USA \\
\hline Steam boilers & 0.03 & 0.00 & 0.00 & 0.65 & 0.09 & 0.01 & 0.07 & 0.03 & 0.00 & 4.88 & 1.74 \\
\hline Aircraft engines & 0.03 & 0.00 & 0.00 & 0.08 & 3.41 & 0.00 & 2.61 & 0.00 & 0.12 & 0.04 & 7.37 \\
\hline Outboard Motors & 0.05 & 2.21 & 0.00 & 0.01 & 0.02 & 0.03 & 0.55 & 0.00 & 0.00 & 8.85 & 0.00 \\
\hline Outboard motors, nes & 0.18 & 0.00 & 0.00 & 0.02 & 0.05 & 0.00 & 1.43 & 0.00 & 0.00 & 3.27 & 0.00 \\
\hline Combustion engines, nes & 0.07 & 0.22 & 0.00 & 0.09 & 0.02 & 0.01 & 0.57 & 0.00 & 0.07 & 1.57 & 2.08 \\
\hline Engines and motors, nes & 0.01 . & 0.00 & 0.00 & 0.52 & 0.01 & 0.00 & 0.07 & 0.00 & 0.00 & 0.14 & 3.54 \\
\hline Rotating electric motors & 0.13 & 0.51 & 0.01 & 0.25 & 0.05 & 0.00 & 2.08 & 0.00 & 0.00 & 1.63 & 1.95 \\
\hline Water turbines & 0.58 & 0.00 & 0.00 & 0.00 & 0.05 & 0.00 & 0.14 & 0.00 & 0.06 & 1.22 & 1.20 \\
\hline Cultivating equipment & 0.37 & 0.01 & 0.00 & 0.26 & 0.03 & 0.00 & 0.02 & 0.00 & 0.01 & 0.13 & 2.34 \\
\hline Harvesting machinery & 0.13 & 0.00 & 0.00 & 0.00 & 0.01 & 0.01 & 0.06 & 0.00 & 0.01 & 0.21 & 2.58 \\
\hline Dairy machinery & 0.00 & 0.00 & 0.00 & 0.00 & 0.01 & 0.18 & 0.02 & 0.00 & 0.00 & 0.05 & 0.98 \\
\hline Wine making machinery & 0.63 & 0.00 & 0.00 & 0.00 & 0.55 & 0.00 & 0.02 & 0.00 & 0.00 & 0.08 & 0.00 \\
\hline Agricultural machinery, nes & 0.15 & 0.00 & 0.00 & 0.00 & 0.01 & 0.44 & 0.14 & 0.00 & 0.43 & 0.01 & 1.06 \\
\hline Construction machinery & 0.03 & 0.00 & 0.01 & 0.04 & 0.46 & 0.00 & 2.78 & 0.00 & 1.02 & 0.36 & 5.04 \\
\hline Spinning machinery & 0.48 & 0.04 & 0.00 & 0.05 & 0.01 & 0.00 & 0.72 & 0.05 & 0.00 & 1.11 & 1.27 \\
\hline Knitting machinery & 0.52 & 0.26 & 0.00 & 0.31 & 0.00 & 0.00 & 0.08 & 0.52 & 0.11 & 1.01 & 0.53 \\
\hline Textile machinery, nes & 0.13 & 0.40 & 0.00 & 0.07 & 0.02 & 0.01 & 0.06 & 0.00 & 0.00 & 0.41 & 1.03 \\
\hline Paper making machinery & 0.00 & 0.00 & 0.00 & 0.08 & 0.04 & 0.00 & 0.03 & 0.00 & 0.00 & 0.53 & 1.38 \\
\hline Bookbinding machinery & 0.01 & 0.00 & 0.00 & 0.09 & 0.01 & 0.00 & 0.48 & 0.00 & 0.00 & 0.09 & 1.73 \\
\hline Printing machinery & 0.01 & 0.09 & 0.00 & 0.02 & 0.04 & 0.00 & 0.18 & 0.00 & 0.02 & 0.27 & 2.37 \\
\hline Grain milling machinery & 0.41 & 0.00 & 0.00 & 0.02 & 0.08 & 0.00 & 0.70 & 0.00 & 0.13 & 0.41 & 0.00 \\
\hline Food processing machinery & 0.14 & 0.01 & 0.00 & 0.01 & 0.06 & 0.00 & 0.04 & 0.00 & 0.05 & 0.17 & 0.00 \\
\hline Machines for special industries & 0.01 & 0.01 & 0.00 & 0.20 & 0.03 & 0.00 & 0.16 & 0.00 & 0.00 & 0.26 & 3.49 \\
\hline Mineral working machinery & 0.18 & 0.00 & 0.00 & 0.10 & 0.20 & 1.27 & 0.19 & 0.00 & 0.00 & 0.48 & 1.35 \\
\hline Special industry machines, nes & 0.35 & 0.19 & 0.00 & 0.05 & 0.49 & 0.02 & 0.80 & 0.00 & 0.15 & 0.79 & 0.60 \\
\hline Metal working machine tools & 0.14 & 0.03 & 0.00 & 0.07 & 0.03 & 0.00 & 0.53 & 0.77 & 0.05 & 0.64 & 1.76 \\
\hline Foundry equipment & 0.10 & 0.00 & 0.00 & 0.00 & 0.34 & 0.00 & 0.01 & 0.00 & 0.20 & 4.69 & 0.00 \\
\hline Rolling mill parts & 0.06 & 0.01 & 0.00 & 0.03 & 0.05 & 0.00 & 0.05 & 0.00 & 0.00 & 3.33 & 0.28 \\
\hline Refrigerating equipment & 0.07 & 0.07 & 0.00 & 0.21 & 0.06 & 0.02 & 0.30 & 0.00 & 0.02 & 1.41 & 0.00 \\
\hline Pumps for liquids & 0.04 & 0.02 & 0.00 & 0.09 & 0.13 & 0.01 & 0.53 & 0.00 & 0.02 & 0.65 & 2.61 \\
\hline Centrifuges and filters & 0.03 & 0.08 & 0.00 & 0.03 & 0.06 & 0.00 & 0.89 & 0.00 & 0.75 & 1.01 & 0.46 \\
\hline Fork lift trucks & 0.01 & 0.04 & 0.00 & 1.27 & 0.04 & 0.00 & 0.14 & 0.01 & 0.01 & 0.94 & 2.68 \\
\hline Lifting and loading machines & 0.11 & 0.03 & 0.00 & 0.16 & 0.16 & 0.04 & 0.34 & 0.00 & 0.00 & 0.78 & $\mathrm{i} .22$ \\
\hline Power hand tools & 0.03 & 0.00 & 0.00 & 0.00 & 0.07 & 0.00 & 0.54 & 0.00 & 0.00 & 0.74 & 2.96 \\
\hline Packing machinery & 0.00 & 0.02 & 0.00 & 0.02 & 0.02 & 0.01 & 0.04 & 0.00 & 0.01 & 0.19 & 1.61 \\
\hline
\end{tabular}


Appendix Table A19.6. Continued

\begin{tabular}{|c|c|c|c|c|c|c|c|c|c|c|c|}
\hline Component Product Group* & China & $\begin{array}{l}\text { Hong } \\
\text { Kong }\end{array}$ & Indonesia & $\begin{array}{c}\text { Rep. of } \\
\text { Korea }\end{array}$ & Malaysia & Philippines & Singapore & $\begin{array}{l}\text { Taiwan, } \\
\text { China }\end{array}$ & Thailand & Japan & USA \\
\hline Non-Electric machinery & 0.09 & 0.10 & 0.00 & 0.08 & 0.10 & 0.00 & 1.31 & 1.37 & 0.00 & 1.35 & 1.02 \\
\hline Office and adding machinery & 0.05 & 3.53 & 0.00 & 0.44 & 0.11 & 0.00 & 1.61 & 0.60 & 0.61 & 1.02 & 3.02 \\
\hline Telecommunications equipment & 0.31 & 2.47 & 0.03 & 1.21 & 0.65 & 0.10 & 1.39 & 2.15 & 0.03 & 2.87 & 1.22 \\
\hline Electric power machinery & 0.12 & 18.40 & 0.00 & 0.74 & 0.91 & 0.00 & 1.05 & 4.03 & 0.00 & 1.57 & 0.59 \\
\hline Switchgear & 0.13 & 0.94 & 0.00 & 0.28 & 0.54 & 0.26 & 3.58 & 1.28 & 5.38 & 1.51 & 1.22 \\
\hline Domestic electrical equipment & 0.58 & 3.12 & 0.00 & 0.19 & 0.07 & 0.60 & 0.42 & 0.00 & 0.04 & 0.70 & 2.24 \\
\hline Electrothermic appliances & 0.15 & 7.45 & 0.00 & 0.00 & 0.15 & 0.01 & 0.85 & 0.00 & 0.01 & 2.92 & 1.68 \\
\hline Electronic components, nes & 0.07 & 1.47 & 0.02 & 1.22 & 8.54 & 1.54 & 7.85 & 0.00 & 0.00 & 2.91 & 2.39 \\
\hline Electronic accumulators & 0.08 & 0.05 & 0.03 & 0.28 & 0.05 & 0.08 & 0.32 & 1.05 & 1.24 & 0.22 & 1.73 \\
\hline Electric lamps and bulbs & 0.14 & 0.28 & 0.00 & 0.16 & 0.01 & 0.14 & 0.03 & 2.22 & 0.09 & 0.50 & 1.25 \\
\hline Eiectricai machinery, nes & 0.11 & 1.82 & 0.00 & 0.10 & 0.12 & 0.00 & 0.11 & 16.44 & 0.64 & 0.47 & 0.00 \\
\hline Motor vehicles and accessories & 1.48 & 0.00 & 0.00 & 0.13 & 0.01 & 0.19 & 0.14 & 0.46 & 0.07 & 1.24 & 2.11 \\
\hline Carriages and cycles & 1.18 & 0.00 & 0.02 & 0.40 & 0.02 & 0.00 & 0.49 & 6.94 & 0.24 & 4.68 & 0.10 \\
\hline Trailers and non-motor vehicles & 0.02 & 0.00 & 0.00 & 1.06 & 0.06 & 0.00 & 0.11 & 0.68 & 0.00 & 0.08 & 0.65 \\
\hline Railroad equipment & 0.22 & 0.00 & 0.00 & 0.30 & 0.01 & 0.00 & 0.01 & 0.01 & 0.06 & 0.94 & 2.14 \\
\hline Aircraft and helicopters & 0.09 & 0.00 & 0.01 & 0.17 & 0.80 & 0.00 & 0.78 & 0.01 & 0.04 & 0.10 & 4.74 \\
\hline Chairs & 0.20 & 0.01 & 0.02 & 0.11 & 0.12 & 0.13 & 0.18 & 0.00 & 0.18 & 0.15 & 0.00 \\
\hline Other furniture parts & 0.67 & 1.00 & 0.17 & 0.31 & 0.24 & 18.20 & 0.26 & 20.12 & 0.00 & 0.07 & 0.00 \\
\hline Measuring or drawing machines & 0.03 & 0.13 & 0.00 & 0.18 & 0.06 & 0.00 & 0.23 & 0.00 & 0.01 & 1.74 & 0.00 \\
\hline Still cameras, nes & 0.04 & 2.92 & 0.00 & 0.71 & 0.63 & 0.00 & 0.37 & 2.36 & 0.03 & 5.79 & 0.89 \\
\hline Cameras under $16 \mathrm{~mm}$ & 0.19 & 0.00 & 0.00 & 0.17 & 6.74 & 0.00 & 6.56 & 0.00 & 0.00 & 4.64 & 0.25 \\
\hline Cameras under $16 \mathrm{~mm}$, nes & 0.10 & 0.02 & 0.00 & 0.14 & 2.87 & 0.00 & 0.24 & 0.00 & 0.41 & 0.25 & 2.75 \\
\hline Unmounted optical elements & 0.10 & 0.47 & 0.00 & 0.35 & 0.25 & 1.42 & 1.94 & 0.78 & 3.21 & 1.20 & 1.94 \\
\hline Clocks and watches & 25.59 & 19.31 & 0.00 & 0.56 & 1.58 & 0.08 & 0.89 & 2.25 & 3.22 & 2.65 & 0.25 \\
\hline Umbrellas and canes & 1.64 & 3.01 & 0.00 & 0.21 & 0.10 & 0.23 & 0.42 & 32.20 & 0.14 & 0.22 & 0.05 \\
\hline MEMO ITEM & & & & & & & & & & & \\
\hline RCA For All Components & 0.60 & 1.16 & 0.01 & 0.39 & 0.39 & 0.27 & 1.15 & 0.99 & 0.66 & 1.42 & 2.15 \\
\hline $\begin{array}{l}\text { No. of Product Groups with } \\
\text { RCAs exceeding unity }\end{array}$ & 4 & 11 & 0 & 4 & 5 & 4 & 12 & 12 & 5 & 26 & 37 \\
\hline
\end{tabular}

* See Table 17.1 for the SITC Revision 2 classification number of each component product group

Source: Computed from United Nations SITC Revision 2 COMTRADE statistics 


\section{$\underline{\text { References }}$}

Amjadi, Azita and Alexander Yeats (1995). Have Transport Costs Contributed to the Relative Decline of Sub-Saharan African Exports, (Washington: World Bank Policy Research Working Paper 1559, December).

Anderson, Kym (1983). "Intensity of Trade Between Pacific Basin Countries," Pacific Economic Papers, no. 102, Australia-Japan Research Center, July.

Asian Development Bank (2002). Asian Development Outlook 2002, (Hong Kong, China: Oxford University Press.

Balassa, Bela (1965). "Trade Liberalization and Revealed Comparative Advantage," The Manchester School of Economic and Social Studies, vol. 33, May.

Crafts, Nicolas (1998). East Asian Growth Before and After the Crisis, (Washington: IMF Staff Working Paper 46).

Drysdale, Peter and Ross Garnaut (1982). "Trade Intensities and the Analysis of Bilateral Trade Flows in a Many Country World," Hitotsubashi Journal of Economics, vol. 22, no. 2, (February)

Falvey, Rodney et. al. (1987). "Product Quality, Intra-Industry Trade, and (Im)perfect Competition," in H. Kierzkowski (ed.), Protection and Competition in International Trade, (Oxford: Basil Blackwell).

Feenstra, Robert (1998). "Trade and Disintegration of Production in the Global Economy," Journal of Economic Perspectives, (fall).

Frankel, Jeffrey (1997). Regional Trading Blocks and the World Economic System, (Washington: Institute for International Economics, October).

General Agreement on Tariffs and Trade (1966). International Trade, 1965, (Geneva: GATT).

Grubel, Herbert and Peter Lloyd). Intra-Industry Trade: The Theory and Measurement of International Trade in Differentiated Products, (New York: Wiley Publishers)

Healey, Derek (1977). Regional Trade Schemes Among Developing Countries: A Survey, (Adelaide: Center for Asian Studies, 1977).

Helleiner, G. (1978). World Market Imperfections and Developing Countries, (Washington: Overseas Development Council).

Hoekman, Bemard and Simeon Djankov (1996). "Intra-Industry Trade, Foreign Direct Investment, and the Re-orientation of Eastern European Exports," unpublished manuscript, (Washington: World Bank).

Hogendorn, Jan (1987). Economic Development, New York: Harper and Row).

Hufbauer, G. C. and J. P. O’Neill (1972). "Unit Values of U.S. Machinery Exports," Journal of International Economics, (August).

Jabar, Tayseer (1971). "The Relevance of Traditional Theory to Less Developed Countries," Journal of Common Market Studies, (March). 
Studies.

Khalaf, Nadim (1974). "Country Size and Trade Concentration," Journal of Development

Kierzkowski, Henryk (2001). "Joining the Global Economy: Experience and Prospects of the Transitional Economies," in Sven Arndt and Henryk Kierzkowski, FRAGMENTATION, (Oxford: Oxford University Press). December.

Kravis, Irving (1970). "Trade as a Handmaiden of Growth", Economic Journal, vol. 80, in press.

Krishna, Pravin (2002). "Are Regional Trade Partners Natural," Journal of Political Economy,

Labys, W. and M. Lord (1990). "Portfolio Optimization and the Design of Latin American Export Diversification Strategies," Journal of Development Studies, (January).

Lary, Hal (1968). Imports of Manufactures from Less Developed Countries, (New York: National Bureau of Economic Research).

Lemoine, F. and D. Unal-Kesenci (2002). China in the International Segmentation of Production Processes, (Paris: Centre d'Etudes Prospectives et d'Information Internationales Working Paper 2002-02, March)

Linneman, Hans (1966). An Econometric Study of International Trade Flows, (Amsterdam: North Holland Publishing Company).

MacBean, Alexander (1966), Export Instability and Economic Growth, (Cambridge: Harvard University Press).

Mayer, Jorg, Arunas Butkevicius, and Ali Kadri (2002). Dynamic Products in World Exports, (Geneva: UNCTAD Discussion Paper No. 159, May).

Michaely, Michael (1994). Trade Preferential Agreements in Latin America: An Ex Ante Assessment, (Washington: World Bank Latin America and Caribbean Region, processed).

$\mathrm{Ng}$, Francis and Alexander Yeats (1999). Production Sharing in Asia: Who Does What for Whom, and Why, (Washington: World Bank Policy Research Working Paper No. 2197, October).

$\mathrm{Ng}$, Francis and Alexander Yeats (2002). "What Can Africa Expect from Its Traditional Exports," (Washington: World Bank Africa Region Working Paper Number 26, February).

Bank, processed)

$\mathrm{Ng}$, Francis and Alexander Yeats (2003), Major East Asian Trade Trends, (Washington: World

Primo Braga, Carlos and Alexander Yeats (1995). "How Minilateral Trading Arrangements May Affect the Post Uruguay Round World," World Bank Policy Research Working Paper No. 974, (Washington: World Bank).

Pulliainen, K. (1963). "A World Trade Study: An Econometric Model of the Pattern of Commodity Flows in International Trade," Economiska, no. 2.

Safadi, Raed and Alexander Yeats (1994). Asian Economic Journal, vol. 8, no. 2 (July).

Safadi, Raed and Alexander: Yeats (1996). "NAFTA's Implications for East Asian Exports," World Bank Policy Research Paper No. 1351, (Washington: World Bank). 
Schiff, Maurice (1999). "Will the Real Natural Trading Partners Please Stand Up," (Washington, World Bank Policy Research Paper).

Tinbergen, Jan (1962). Shaping the World Economy: Suggestions for an International Economic Policy, (New York: The Twentieth Century Fund).

Tuong, Ho Dac and Alexander Yeats (1977). "On the Relation Between Country Size and Trade Concentration," Economia Internazionale, (November).

UNCTAD (various issues), Handbook of International Trade and Development Statistics, (New York: United Nations).

Viatsos, C. (1978). "Crisis in Regional Economic Cooperation Among Developing Countries: A Survey," World Development, (June).

World Bank (1994). "External Markets and China's Exports," chapter 7 in China: Foreign Trade Reform, (Washington: World Bank).

World Bank (2000a). 2000 World Development Indicators, (Washington: World Bank).

World Bank (2000b). Regional Blocks, (Washington: World Bank and Oxford University Press).

World Bank (2001a). Global Economic Prospects and Developing Countries, 2001, (Washington: World Bank).

World Bank (2001b). Ghana: International Competitiveness - Opportunities and Challenges Facing Non-Traditional Exports, (World Bank: Macroeconomics 4 Africa Region, January).

World Bank (2003). East Asia Integrates: A Trade Policy Agenda for Shared Growth, (Washington: World Bank, processed).

Yeats, Alexander (1989). Shifting Patterns of Comparative Advantage: Manufactured Exports of Developing Countries, (Washington: World Bank Policy Research Working Paper No. 165, March).

Yeats, Alexander (1990). "Do African Countries Pay More for Imports? Yes," World Bank Economic Review, vol. 4, no. 1 (January).

Yeats, Alexander (1998a). "Does Mercosur's Trade Performance Raise Concerns About the Effects of Regional Trade Arrangements?," World Bank Economic Review, 12 (1), 1-28

Yeats, Alexander (1998b). "What Can Be Expected from African Regional Trade Arrangements," Policy Research Working Paper No. 2004, (Washington: World Bank, November).

Yeats, Alexander (1999). "The East Asian Economic Crisis: Was the Region's Export Performance a Factor." A paper presented at the ASEM Regional Economists workshop From Recovery to Sustainable Development (September), held in Bali, Indonesia.

Yusuf, Shahid and Simon Evenett (2002). Can East Asia Compete? Innovation for Global Markets, (Washington: World Bank and Oxford University Press). 


\section{Appendix 1 \\ Hong-Kong's Re-Exports and Other East Asian Trade Data Problems}

A serious problem complicating analyses of the composition and geographic directions of East Asian intra-trade is the influence of major entrepot centers, particularly Hong Kong, in the region. Entrepot centers consist of a country, or countries, that serve as an "intermediate way-point" or transshipment center for goods exchanged between two other countries. For example, a relatively high share of Chinese exports pass through Hong Kong before being re-exported to other destinations in East Asia, North America, Europe, or other locations. As a result of these transshipments a specific country, like China, may not be able to correctly identify the destinations of its exports in its own official trade data. The United States also serves as an important entrepot for some goods shipped from East Asia to Europe or Latin America.

Statistics on entrepot trade reported by individual countries to the United Nations provide some indication as to the dimensions of this activity in East Asia. The overall global magnitude of entrepot activity is almost certainly larger as many countries fail to report their transshipments to the United Nations. As indicted below, Hong Kong reported re-exports of $\$ 170$ billion in 2001, which was almost 60 percent higher than the corresponding total transshipments of the other nine largest entrepot centers.

Table A1. Major Global Entrepot Centers as Reflected in 2001 COMTRADE Statistics

\begin{tabular}{|l|c|l|c|}
\hline Entrepot Center & $\begin{array}{c}\text { Re-Exports } \\
(\$ \text { million })\end{array}$ & Entrepot Center & $\begin{array}{c}\text { Re-Exports } \\
\text { (\$ million) }\end{array}$ \\
\hline Hong Kong, China & $170,793.4$ & New Zealand & 459.6 \\
United States & $65,003.2$ & Macau & 416.6 \\
Taiwan, China & $3,457.0$ & Jordan & 387.0 \\
Saudi Arabia & 970.7 & Malta & 199.9 \\
Cyprus & 591.3 & Sri Lanka & 85.3 \\
\hline
\end{tabular}

Source: United Nations COMTRADE Statistics.

Viewed somewhat differently, in 2001 Hong Kong's re-exports exceeded the total global merchandise exports of countries like Spain, Sweden, Switzerland, or Belgium. The importance of this point is further highlighted by the growth in Hong Kong's entrepot trade. From 1980 to 2001, Hong Kong's total transshipments increased more than 28 fold, or at an annual rate of approximately 17.5 percent which was about 11 percentage points higher than the corresponding growth rate for world trade (see the statistics presented below).

Table A2. The Global Value of Hong Kong's Re-Exports in Selected Years

\begin{tabular}{|c|c|c|c|c|c|}
\hline Year & $\begin{array}{c}\text { Re-Exports } \\
(\$ \text { million })\end{array}$ & Year & $\begin{array}{c}\text { Re-Exports } \\
(\$ \text { million })\end{array}$ & Year & $\begin{array}{c}\text { Re-Exports } \\
\text { (\$ million) }\end{array}$ \\
\hline 1980 & 6,033 & 1995 & 143,925 & 1999 & 152,022 \\
1985 & 13,459 & 1997 & 160,894 & 2001 & 179,147 \\
1990 & 53,388 & 1998 & 150,276 & 2001 & 170,793 \\
\hline
\end{tabular}

Source: United Nations COMTRADE Statistics.

As indicated in the data that follow, the major destinations of Hong Kong's entrepot trade were geographically diversified in 2001 , but China received more than one-third of this exchange, while about one-fifth of the total went to the United States. As reported, four Asian countries, namely, Japan, Taiwan (China), Singapore, and the Republic of Korea received over \$21 billion in Hong Kong's re-exports in the year 2001. The magnitude of East Asian re-exports makes it difficult for some exporting countries to correctly identify the true direction of regional and non-regional trade in their official statistics. 
Table A3. Major Destinations of Hong Kong's Re-Exports in 2001

\begin{tabular}{|l|c|c|l|c|c|}
\hline Destination & $\begin{array}{c}\text { Re-Exports } \\
(\$ \text { million })\end{array}$ & $\begin{array}{c}\text { Share of } \\
\text { Total }(\%)\end{array}$ & Destination & $\begin{array}{c}\text { Re-Exports } \\
(\$ \text { million })\end{array}$ & $\begin{array}{c}\text { Share of } \\
\text { Total }(\%)\end{array}$ \\
\hline World & 170,793 & 100.0 & United Kingdom & 6,056 & 3.5 \\
China & 63,809 & 37.4 & Germany & 5,870 & 3.4 \\
United States & 36,265 & 21.2 & Taiwan, China & 3,855 & 2.3 \\
European Union (15) & 24,213 & 14.2 & Singapore & 3,488 & 2.0 \\
Japan & 10,721 & 6.3 & Korea, Rep. of & 3,187 & 1.9 \\
\hline
\end{tabular}

Source: United Nations COMTRADE Statistics.

A second unrelated trade data problem is that some East Asian countries, particularly the Philippines, fail to properly report the composition of goods shipped from their own export processing zones (EPZs), and simply lump these exports into one highly aggregate SITC (93i) category "special transactions." For example, between 1992 and 1995 the Philippines classified between 31 to 37 percent of its total exports in this "special transactions" category in spite of the very diverse nature of the goods being exchanged. Available export statistics could, therefore, be quite misleading as to the composition of the goods being shipped to regional and non-regional markets. A similar problem exists, to a lesser extent, in some other Asian countries trade data.

While no fully satisfactory solutions exist for these problems, it is generally held that import statistics can provide far more accurate information on the direction and composition of trade than export data when entrepot activity is significant, or where countries are inappropriately utilizing the SITC 931 category "special transactions" for classifying export statistics. Importing countries are far more likely to know the correct origins, and composition, of their trade since there normally are important legal penalties for incorrectly specifying this information on customs vouchers. In contrast, entrepot centers normally have no legal or other obligation to inform the originating country of the true final destination of its exports. The potential importance of this point is reflected in official published trade statistics of the United States and China. For example, in 1998 China was able to identify only $\$ 37,984$ million of its exports as destined for the United States, while the United States reported approximately $\$ 75,095$ of imports from China. The discrepancy closely matches the $\$ 33,609$ US re-export total reported by Hong Kong.

For these reasons, import statistics will be used in this analysis to assess the geographic directions and composition of East Asian countries' exports. As an example, China, Thailand, or Malaysia's exports will be tabulated using the reported imports of its trading partners. An attraction of this approach is that import statistics are generally thought to be more accurate than export data since the former are used for the application of direct trade control measures like tariffs. It should be noted that there may be some slight differences in the levels of trade reflected in import and export statistics since the former are normally valued on a c.i.f. basis while the latter are reported in f.o.b. terms. ${ }^{39}$

A third East Asian data problem concerns countries that failed to report their official trade statistics to the United Nations, or report data very late and on an irregular basis. For example, Laos PDR has never reported statistics to UN COMTRADE, the last year of available data for Cambodia was 1972, and Vietnam stopped reporting trade statistics to the United Nations in 1989. Brunei and Mongolia have been consistent but late reporters in that 1998 is the last year for which United Nations statistics are available for the former. While the East Asian country coverage is complete in the very aggregate IMF

\footnotetext{
${ }^{39}$ United Nations regulations for the compilation of trade data required that goods imported for re-export (without any significant further processing) not be included in a country's official import statistics. If this practice is not being followed fully it could impart a bias in East Asian trade data. Obviously, given its role as a major entrepot, the question is of primary concern in the case of Hong Kong.
} 
Direction of Trade data (which only provides import and export totals), the lack of detailed UN COMTRADE statistics precluded some analyses of these non-reporting countries trade trends.

Two other special data problems should be noted. China failed to report its trade statistics to the United Nations prior to 1987 so most detailed analyses of its trade performance could not be conducted earlier. Second, Singapore failed to report any trade with Indonesia after 1964, purportedly due to a high volume of illicit trade (smuggling) between the countries. As such, Singapore's imports from, and exports to, Indonesia had to be tabulated from the latter's reported UN trade statistics. 
Appendix Table A4

East Asian Countries Largest Regional Exports in 2001

$\begin{array}{ll} & \frac{\text { Country/SITC/Product }}{\text { BRUNEI }} \\ & \text { Total Exports } \\ 3330 & \text { Petroleum oils } \\ 3413 & \text { Petroleum gases } \\ 8451 & \text { Jerseys and pullovers } \\ 7932 & \text { Ships and boats } \\ 8462 & \text { Under garments of cotton } \\ 8459 & \text { Knit outer garments } \\ 8452 & \text { Knit dresses and skirts } \\ 8441 & \text { Men's shirts of textile fabrics } \\ 8973 & \text { Jewellery of gold or silver } \\ 8439 & \text { Outer garments of textile fabric } \\ 8429 & \text { Other outer garments } \\ 8435 & \text { Blouses of textile fabrics } \\ 2820 & \text { Waste and scrap metal } \\ 6954 & \text { Interchangeable tools } \\ 6552 & \text { Knitted or crocheted fabrics }\end{array}$

\section{CAMbodia}

\section{Total Exports}

2320 Natural rubber latex

6341 Wood sawn lengthwise

6342 Plywood sheets

9710 Non-monetary gold

0360 Crustaceans

8459 Other knit outer garments

8452 Knit dresses or skirts

8462 Under garments of cotton

2483 Non-coniferous wood

7932 Ships and boats

8439 Other textile outer garments

8435 Blouses of textile fabrics

0341 Fish, fresh

2820 Waste and scrap metal

8441 Men's shirts of textile fabrics

\section{CHINA}

Total Exports

8942 Children's toys and games

7599 Parts of office machinery

8510 Footwear

7649 Parts telecom equipment

8451 Jerseys and pullovers

8310 Travel goods and handbags

7712 Other electric power machinery

7643 Radiotelephonic equipment

8459 Other knit outer garments

7638 Other sound recorders

$\begin{array}{cc}\begin{array}{c}\text { Exports } \\ \text { (\$000) }\end{array} & \begin{array}{c}\text { Export } \\ \text { Share }(\%)\end{array} \\ 1,212,834 & 100.0 \\ 829,020 & 68.4 \\ 156,373 & 12.9 \\ 53,463 & 4.4 \\ 41,005 & 3.4 \\ 35,551 & 2.9 \\ 32,445 & 2.7 \\ 5,546 & 0.5 \\ 5,538 & 0.5 \\ 5,183 & 0.4 \\ 4,371 & 0.4 \\ 3,702 & 0.3 \\ 1,555 & 0.1 \\ 1,446 & 0.1 \\ 1,273 & 0.1 \\ 1,246 & 0.1\end{array}$

$\begin{array}{cc}153,549 & 100.0 \\ 23,883 & 15.6 \\ 20,669 & 13.5 \\ 13,035 & 8.5 \\ 11,902 & 7.8 \\ 6,534 & 4.3 \\ 5,720 & 3.7 \\ 4,359 & 2.8 \\ 4,346 & 2.8 \\ 4,134 & 2.7 \\ 4,075 & 2.7 \\ 3,650 & 2.4 \\ 3,048 & 2.0 \\ 2,930 & 1.9 \\ 2,679 & 1.7 \\ 2,484 & 1.6\end{array}$

$124,282,677$

100.0

$5,804,360$

$5,613,303$

$4,832,699$

$4,454,386$

$3,610,732$

$3,130,025$

$2,517,265$

$2,427,842$

$2,021,568$

$1,957,036$

\section{Country/SITC/Product \\ MALAYSIA}

Total Exports

7764 Electronic microcircuits

7599 Parts of office machinery

3330 Petroleum oils

7524 Digital storage units

3413 Petroleum gases

7763 Diodes and transistors

7649 Parts of telecom equipment

7643 Radiotelephonic equipment

7788 Other electrical machinery

4242 Palm oil

7768 Piezo-electric crystals

7525 Peripheral electronic units

7722 Printed circuits and parts

2483 Non-coniferous wood

7761 Television picture tubes

\section{MONGOLIA}

Total Exports

2871 Copper ores

6114 Bovine leather

6115 Sheep and lamb skin leather

2687 Sheep's and lamb wool

2879 Other non-ferrous ores

6552 Knitted or crocheted fabrics

2111 Bovine \& equine hides

8451 Jerseys and pullovers

2683 Fine animal hair

2882 Other non-ferrous waste

8471 Clothing accessories

2682 Sheep or lamb wool

0577 Edible nuts

3330 Petroleum oils

8423 Trousers of textile fabric

\section{PHILIPPINES}

Total Exports

7764 Electronic microcircuits

7599 Parts of office machinery

7524 Digital central storage units

7763 Diodes and transistors

7768 Piezo-electric crystals

7649 Parts of telecom equipment

6821 Copper alloys

7788 Other electrical machinery

9710 Non-monetary gold

0573 Bananas

\section{Exports Export \\ (\$000) Share (\%)}

$\begin{array}{cc}44,724,458 & 100.0 \\ 11,196,817 & 25.0 \\ 5,339,691 & 11.9 \\ 1,452,430 & 3.2 \\ 1,304,255 & 2.9 \\ 1,254,136 & 2.8 \\ 1,219,489 & 2.7 \\ 918,126 & 2.1 \\ 830,585 & 1.9 \\ 714,626 & 1.6 \\ 637,169 & 1.4 \\ 516,428 & 1.2 \\ 515,456 & 1.2 \\ 443,989 & 1.0 \\ 441,139 & 1.0 \\ 434,629 & 1.0\end{array}$

$\begin{array}{cc}242,697 & 100.0 \\ 175,901 & 72.5 \\ 8,446 & 3.5 \\ 7,302 & 3.0 \\ 7,001 & 2.9 \\ 6,939 & 2.9 \\ 6,416 & 2.6 \\ 4,685 & 1.9 \\ 3,384 & 1.4 \\ 2,742 & 1.1 \\ 2,417 & 1.0 \\ 2,399 & 1.0 \\ 1,895 & 0.8 \\ 1,840 & 0.8 \\ 1,603 & 0.7 \\ 1,546 & 0.6\end{array}$

$1,472,7171 \quad 100.0$

$6,897,703 \quad 46.8$

$1,358,320 \quad 9.2$

$1,169,871 \quad 7.9$

$574,751 \quad 3.9$

$441,797 \quad 3.0$

$292,435 \quad 2.0$

$266,434 \quad 1.8$

$204,231 \quad 1.4$

$163,090 \quad 1.1$

$155,865 \quad 1.1$ 


\begin{tabular}{|c|c|c|c|c|c|c|}
\hline & $\begin{array}{l}\text { Country/SITC/Product } \\
\text { CHINA, CONTINUED }\end{array}$ & $\begin{array}{l}\text { Exports } \\
(\$ 000)\end{array}$ & $\begin{array}{c}\text { Export } \\
\text { Share (\%) }\end{array}$ & $\begin{array}{l}\text { Country/SITC/Product } \\
\text { PHILIPPINES, CONTINUED }\end{array}$ & $\begin{array}{l}\text { Exports } \\
(\$ 000)\end{array}$ & $\begin{array}{c}\text { Export } \\
\text { Share (\%) }\end{array}$ \\
\hline 8439 & Other textile outer garments & $1,846,140$ & 1.5 & 7522 Data processing machines & 154,511 & 1.0 \\
\hline 8462 & Under garments of cotton & $1,836,566$ & 1.5 & 7525 Peripheral units & 147,652 & 1.0 \\
\hline 8939 & Miscellaneous articles & $1,798,534$ & 1.4 & 7643 Radiotelephonic equipment & 139,723 & 0.9 \\
\hline 7525 & Peripheral units & $1,749,821$ & 1.4 & 7849 Parts of motor vehicles & 130,102 & 0.9 \\
\hline \multirow[t]{3}{*}{7788} & Other electrical machinery & $1,674,432$ & 1.3 & 7162 Electric motors \& generators & 110,593 & 0.8 \\
\hline & HONG KONG & & & SINGAPORE & & \\
\hline & Total Exports & $19,596,694$ & 100.0 & Total Exports & $38,076,065$ & 100.0 \\
\hline 7764 & Electronic microcircuits & $2,308,751$ & 11.8 & 7764 Electronic microcircuits & $7,573,415$ & 19.9 \\
\hline 7599 & Parts of office machinery & 996,219 & 5.1 & 7599 Parts of office machinery & $1,946,760$ & 5.1 \\
\hline 7649 & Parts of telecom equipment & 303,804 & 4.1 & 7524 Digital storage units & $1,925,296$ & 5.1 \\
\hline 6522 & Woven cotton fabrics & 529,720 & 2.7 & 3341 Motor spirits & $1,342,493$ & 3.5 \\
\hline 7763 & Diodes and transistors & 510,115 & 2.6 & 3343 Gas oils & $1,257,389$ & 3.3 \\
\hline 7788 & Other electrical machinery & 507,352 & 2.6 & 7768 Piezo-electric crystals & $1,077,100$ & 2.8 \\
\hline 7721 & Electrical switches and relays & 464,961 & 2.4 & 3344 Fuel oils, nes. & 950,199 & 2.5 \\
\hline 7722 & Printed circuits and parts & 424,296 & 2.2 & 7788 Other electrical machinery & 815,604 & 2.1 \\
\hline 6552 & Knitted fabrics & 386,173 & 2.0 & 3342 Kerosene & 813,982 & 2.1 \\
\hline 9710 & Non-monetary gold & 383,418 & 2.0 & 7643 Radiotelephonic equipment & 800,989 & 2.1 \\
\hline 7712 & Other electric power machinery & 351,716 & 1.8 & 7763 Diodes and transistors & 794,581 & 2.1 \\
\hline 8451 & Jerseys and pullovers & 332,357 & 1.7 & 7649 Parts of telecom equipment & 703,142 & $1: 8$ \\
\hline 8710 & Optical instruments \& apparatus & 320,268 & 1.6 & 7721 Electrical switches \& relays & 639,436 & 1.7 \\
\hline 7643 & Radiotelephonic equipment & 284,785 & 1.5 & 3345 Lubricating oils & 529,810 & 1.4 \\
\hline \multirow[t]{3}{*}{7768} & Piezo-electric crystals & 280,852 & 1.4 & 5831 Polyethylene & 441,127 & 1.2 \\
\hline & INDONESIA & & & TAIWAN & & \\
\hline & Total Exports & $16,811,795$ & 100.0 & Total Exports & $59,992,028$ & 100.0 \\
\hline 3330 & Petroleum oils & $1,881,283$ & 11.2 & 7764 Electronic microcircuits & $11,136,248$ & 18.6 \\
\hline 3413 & Petroleum gases & $1,810,170$ & 10.8 & 7599 Parts of office machinery & $3,389,585$ & 5.7 \\
\hline 3222 & Other coal & $979 ; 430$ & 5.8 & 5833 Polystyrene & $1,756,548$ & 2.9 \\
\hline 2517 & Chemical wood pulp & 655,967 & 3.9 & 6531 Woven synthetic fabrics & $1,508,580$ & 2.5 \\
\hline 2483 & Non-coniferous wood & 521,498 & 3.7 & 7768 Piezo-electric crystals & $1,325,876$ & 2.2 \\
\hline 2871 & Copper ores & $.457,154$ & 2.7 & 7284 Specialized machinery & $1,259,280$ & 2.1 \\
\hline 6342 & Plywood sheets & 426,793 & 2.5 & 7722 Printed circuits and parts & $1,241,545$ & 2.1 \\
\hline 7649 & Parts of telecom equipment & 309,752 & 1.8 & 7788 Other electrical machinery & $1,135,700$ & 1.9 \\
\hline 6415 & Paper and paperboard & 263,535 & 1.6 & 6552 Knit fabrics & $1,084,495$ & 1.8 \\
\hline 5138 & Poly carboxylic acids & 246,201 & 1.5 & 6746 Iron sheets \& plates & $1,068,364$ & 1.8 \\
\hline 2472 & Saw logs and veneer logs & 245,375 & 1.5 & 6822 Copper alloys, worked & 973,000 & 1.6 \\
\hline 6821 & Copper and copper alloys & 233,243 & 1.4 & 7763 Diodes and transistors & 955,906 & 1.6 \\
\hline 6513 & Cotton yarn & 222,572 & 1.3 & 65.73 Coated textile fabrics & 840,704 & 1.4 \\
\hline 7599 & Parts of office machinery & 220,605 & 1.3 & 5834 Polyvinyl chloride & 772,039 & 1.3 \\
\hline \multirow[t]{3}{*}{7525} & Peripheral units \& adapters & 213,491 & 1.3 & 6514 Yarn of synthetic fibers & 768,990 & 1.3 \\
\hline & KOREA & & & THAILAND & & \\
\hline & TOTAL TRADE & $52,510,660$ & 100.0 & Total Exports & $22,020,395$ & 100.0 \\
\hline 7764 & Electronic microcircuits & $6,222,941$ & 11.9 & 7599 Parts of office machinery & $2,634,716$ & 12.0 \\
\hline 7643 & Radiotelephonic equipment & $3,151,544$ & 6.0 & 7764 Electronic microcircuits & $1,977,948$ & 9.0 \\
\hline 7525 & Peripheral units \& adapters & $1,619,449$ & 3.1 & 7524 Digital storage units & $1,323,757$ & 6.0 \\
\hline 7649 & Parts of telecom equipment & $1,293,369$ & 2.5 & 2320 Natural rubber latex & 784,259 & 3.6 \\
\hline 5112 & Cyclic hydrocarbons & $1,136,874$ & 2.2 & 7162 Electric motors \& generators & 527,486 & 2.4 \\
\hline
\end{tabular}




\section{Country/SITC/Product}

KOREA, CONTINUED

6531

5833

3343

7768

7762

6746

5138

6114

7599

3344

\section{LAOS}

Total Exports

2483 Non-coniferous wood

2472 Saw logs and veneer logs

0011 Bovine animals.

2482 Sawn wood

2876 Tin ores.

2875 Zinc ores

9310 Special transactions

3222 Other coal

7821 Motor vehicles and trucks

2471 Saw logs and veneer logs, nes

2924 Seeds used in perfumery

0548 Vegetable roots \& tubers

2922 Shellac

6342 Plywood sheets

2450 Fuel wood

\section{Exports \\ $(\$ 000)$ \\ Export \\ Share (\%)}

$1,081,540$

$1,052,887$

$1,013,222$

974,947

926,614

889,304

880,417

835,121

818,910

803,474

102,230

49,941

19,799

5,124

4,014

2,828

1,828

1,715

1,713

1,612

1,308

1,173

948

849

808

704
2.1

2.0

1.9

1.9

1.8

1.7

1.7

1.6

1.6

1.5

\section{0}

48.9

19.4

5.0

3.9

2.8

1.8

1.7

1.7

1.6

1.3

1.1

0.9

0.8

0.8

0.7

\section{Country/SITC/Product \\ THAILAND, CONTINUED}

5833 Polystyrene

7763 Diodes and transistors

0422 Rice semi- or wholly milled

7649 Parts of telecom equipment

0611 Beet and cane sugar

7525 Peripheral units \& adapters

0579 Fruit, fresh or dried

5832 Polypropylene

7768 Piezo-electric crystals

7415 Air conditioning machines

VIETNAM

Total Exports

3330 Petroleum oils

7721 Electrical switches

0422 Rice semi- or wholly milled

0360 Crustaceans

7722 Printed circuits and parts

2320 Natural rubber latex

8510 Footwear

7599 Parts of office machinery

0579 Fruit, fresh or dried.

8219 Other furniture and parts

7761 Television picture tubes

0548 Vegetable roots \& tubers

3221 Anthracite coal

0711 Coffee

5146 Oxygen-function compounds
Exports Export

$(\$ 000)$ Share $(\%$

$456,030 \quad 2.1$

$444,933 \quad 2.0$

$424,568 \quad 1.9$

$371,159 \quad 1.7$

$289,123 \quad 1.3$

$281,982 \quad 1.3$

$271,171 \quad 1.2$

$264,874 \quad 1.2$

$259,556 \quad 1.2$

$207,987 \quad 0.9$

$4,062,245 \quad 100.0$

$1,664,199 \quad 41.0$

$159,617 \quad 3.9$

$152,894 \quad 3.8$

$144,843 \quad 3.6$

$139,202 \quad 3.4$

$83,588 \quad 2.1$

$\begin{array}{ll}71,356 & 1.8\end{array}$

$47,595 \quad 1.2$

$45,308 \quad 1.1$

$43,408 \quad 1.1$

$40,475 \quad 1.0$

$38,629 \quad 1.0$

$34,219 \quad 0.8$

$30,945 \quad 0.8$

$\begin{array}{ll}29,613 & 0.7\end{array}$

Source: UN COMTRADE statistics. 
Appendix Table A5

East Asia's Largest Four-Digit SITC (Rev. 2) Exports to Japan

\begin{tabular}{|c|c|c|c|c|c|c|}
\hline \multirow{2}{*}{ SITC No. } & \multirow[b]{2}{*}{ Product Description } & \multicolumn{2}{|c|}{ Export Value $(\$ 000)$} & \multicolumn{2}{|c|}{ Share of Exports \% } & \multirow{2}{*}{$\begin{array}{c}\text { Share } \\
\text { Change }\end{array}$} \\
\hline & & $\underline{1985}$ & $\underline{2001}$ & $\underline{1985}$ & $\underline{2001}$ & \\
\hline & TOTAL EXPORTS & $35,006,728$ & $145,002,541$ & 100.00 & 100.00 & 0.00 \\
\hline 7764 & Electronic microcircuits & 106,679 & $8,834,146$ & 0.30 & 6.09 & 5.79 \\
\hline 3413 & Petroleum gases & $6,496,234$ & $8,618,857$ & 18.56 & 5.94 & -12.61 \\
\hline 7599 & Parts of office machinery & 69,182 & $5,064,704$ & 0.20 & 3.49 & 3.30 \\
\hline 3330 & Petroleum oils & $7,791,853$ & $3,385,009$ & 22.26 & 2.33 & -19.92 \\
\hline 8451 & Jerseys and pullovers & 351,624 & $3,043,494$ & 1.00 & 2.10 & 1.09 \\
\hline 9310 & Special transactions & 627,818 & $3,005,086$ & 1.79 & 2.07 & 0.28 \\
\hline 7649 & Parts of telecom equipment & 111,016 & $2,967,883$ & 0.32 & 2.05 & 1.73 \\
\hline 7525 & Peripheral units including adapters & 18,829 & $2,805,570$ & 0.05 & 1.93 & 1.88 \\
\hline 7524 & Digital central storage units & 6 & $2,784,993$ & 0.00 & 1.92 & 1.92 \\
\hline 3341 & Motor spirit and other light oils & $1,261,262$ & $2,457,621$ & 3.60 & 1.69 & -1.91 \\
\hline 8510 & Footwear & 271,935 & $2,272,008$ & 0.78 & 1.57 & 0.79 \\
\hline 7523 & Complete digital processing equipment & 743 & $2,204,222$ & 0.00 & 1.52 & 1.52 \\
\hline 0360 & Crustaceans & $1,014,867$ & $2,187,799$ & 2.90 & 1.51 & -1.39 \\
\hline 8439 & Other textile outer garments & 59,719 & $2,060,961$ & 0.17 & 1.42 & 1.25 \\
\hline 7638 & Other sound recorders & 9,957 & $1,904,222$ & 0.03 & 1.31 & 1.28 \\
\hline 7611 & Color television receivers & 5,328 & $1,874,914$ & 0.02 & 1.29 & 1.28 \\
\hline 8462 & Under garments of cotton & 118,688 & $\mathrm{I}, 789,840$ & 0.34 & 1.23 & 0.90 \\
\hline 8942 & Children s toys and games. & 60,335 & $1,764,205$ & 0.17 & 1.22 & 1.04 \\
\hline 7522 & Complete digital data processing machines & 318 & $1,725,974$ & 0.00 & 1.19 & 1.19 \\
\hline 7731 & Insulated electrical wire & 8,006 & $1,686,788$ & 0.02 & 1.16 & 1.14 \\
\hline 6342 & Plywood sheets & 50,387 & $1,592,357$ & 0.14 & 1.10 & 0.95 \\
\hline 8310 & Travel goods and handbags & 40,519 & $1,575,179$ & 0.12 & 1.09 & 0.97 \\
\hline 8219 & Other furniture and parts & 118,901 & $1,544,285$ & 0.34 & 1.07 & 0.73 \\
\hline 3222 & Other coal & 187,646 & $1,422,334$ & 0.54 & 0.98 & 0.44 \\
\hline 7712 & Other electric power machinery & 44,865 & $1,416,974$ & 0.13 & 0.98 & 0.85 \\
\hline 7788 & Other electrical equipment & 62,384 & $1,314,368$ & 0.18 & 0.91 & 0.73 \\
\hline 7641 & Electrical and telephonic line & 9,749 & $1,310,827$ & 0.03 & 0.90 & 0.88 \\
\hline 8459 & Other knit outer garments & 150,074 & $1,303,814$ & 0.43 & 0.90 & 0.47 \\
\hline 0342 & Frozen fish (excluding fillets) & 353,075 & $1,235,742$ & 1.01 & 0.85 & -0.16 \\
\hline 7721 & Electrical switches and relays & 46,761 & $1,216,875$ & 0.13 & 0.84 & 0.71 \\
\hline 0371 & Fish, prepared or preserved & 184,057 & $1,153,974$ & 0.53 & 0.80 & 0.27 \\
\hline 8939 & Miscellaneous articles & 31,687 & $1,116,852$ & 0.09 & 0.77 & 0.68 \\
\hline 8423 & Trousers and breeches & 68,621 & $1,050,003$ & 0.20 & 0.72 & 0.53 \\
\hline 8429 & Other textile outer garments & 46,843 & 995,424 & 0.13 & 0.69 & 0.55 \\
\hline 0372 & Crustaceans, prepared or preserved & 74,692 & 850,360 & 0.21 & 0.59 & 0.37 \\
\hline 7162 & Electric motors \& generators & 6,452 & 835,783 & 0.02 & 0.58 & 0.56 \\
\hline 8431 & Coats and jackets of textile fabric & 51,060 & 793,032 & 0.15 & 0.55 & 0.40 \\
\hline 5989 & Chemical products and preparation:s, & 64,855 & 792,767 & 0.19 & 0.55 & 0.36 \\
\hline 8710 & Optical instruments and apparatus & 6,407 & 788,965 & 0.02 & 0.54 & 0.53 \\
\hline 3342 & Kerosene and other medium oils & 327,742 & 767,845 & 0.94 & 0.53 & -0.41 \\
\hline 7763 & Diodes and transistors & 85,970 & 757,473 & 0.25 & 0.52 & 0.28 \\
\hline 8983 & Gramophone records & 28,947 & 752,179 & 0.08 & 0.52 & 0.44 \\
\hline 7849 & Other parts of motor vehicles & 19,932 & 751,297 & 0.06 & 0.52 & 0.46 \\
\hline 8441 & Men's shirts & 80,656 & 739,647 & 0.23 & 0.51 & 0.28 \\
\hline 8947 & Other sporting goods & 127,599 & 711,141 & 0.36 & 0.49 & 0.13 \\
\hline
\end{tabular}


Appendix Table A5. Continued

\begin{tabular}{|c|c|c|c|c|c|c|}
\hline SITC No. & Product Description & $\underline{1985}$ & $\underline{2001}$ & $\underline{1985}$ & $\underline{2001}$ & Change \\
\hline 6584 & Bed and table linen & 45,908 & 705,861 & 0.13 & 0.49 & 0.36 \\
\hline 6613 & Building \& monumental stone & 116,286 & 699,534 & 0.33 & 0.48 & 0.15 \\
\hline 7758 & Electro-thermal appliances. & 2,981 & 679,315 & 0.01 & 0.47 & 0.46 \\
\hline 8211 & Chairs and parts & 43,798 & 661,937 & 0.13 & 0.46 & 0.33 \\
\hline 7628 & Other radio-broadcast receivers & 9,295 & 652,912 & 0.03 & 0.45 & 0.42 \\
\hline 0341 & Fish, fresh or chilled & 275,328 & 651,415 & 0.79 & 0.45 & -0.34 \\
\hline 8931 & Articles for conveyance or packing & 11,613 & 645,613 & 0.03 & 0.45 & 0.41 \\
\hline 0149 & Other prepared or preserved meat & $7,297^{\circ}$ & 632,877 & 0.02 & 0.44 & 0.42 \\
\hline 8212 & Furniture for medical establishments & 50,913 & 621,310 & 0.15 & 0.43 & 0.28 \\
\hline 8435 & Blouses of textile fabrics & 35,261 & 619,880 & 0.10 & 0.43 & 0.33 \\
\hline 0546 & Vegetables, frozen & 114,240 & 612,990 & 0.33 & 0.42 & 0.10 \\
\hline 0114 & Poultry\& edible offal & 68,021 & 596,610 & 0.19 & 0.41 & 0.22 \\
\hline 7722 & Printed circuits and parts & 3,690 & 571,338 & 0.01 & 0.39 & 0.38 \\
\hline 8811 & Photographic cameras and parts & 34,895 & 566,626 & 0.10 & 0.39 & 0.29 \\
\hline 8472 & Clothing accessories, knitted & 50,773 & 564,388 & 0.15 & 0.39 & 0.24 \\
\hline 2483 & Wood of non-coniferous species & 222,012 & 561,534 & 0.63 & 0.39 & -0.25 \\
\hline 7528 & Off-line data processing equipment. & 71 & 540,641 & 0.00 & 0.37 & 0.37 \\
\hline 7591 & Parts of office machinery & 4,218 & 529,312 & 0.01 & 0.37 & 0.35 \\
\hline 2871 & Copper ores $\&$ concentrates & 318,583 & 508,892 & 0.91 & 0.35 & -0.56 \\
\hline 3343 & Gas oils & 42,482 & 503,929 & 0.12 & 0.35 & 0.23 \\
\hline 2320 & Natural rubber latex & 417,283 & 497,150 & 1.19 & 0.34 & -0.85 \\
\hline 0545 & Other fresh or chilled vegetables & 56,630 & 486,895 & 0.16 & 0.34 & 0.17 \\
\hline 8422 & Men's suits of textile fabrics & 10,186 & 485,350 & 0.03 & 0.33 & 0.31 \\
\hline 8434 & Women's skirts of textile fabrics & 8,917 & 481,079 & 0.03 & 0.33 & 0.31 \\
\hline 6589 & Other made-up textile articles & 22,548 & 478,982 & 0.06 & 0.33 & 0.27 \\
\hline 8720 & Medical instruments and appliances & 4,313 & 473,075 & 0.01 & 0.33 & 0.31 \\
\hline 5823 & Alkyds and other polyesters & 3,905 & 472,020 & 0.01 & 0.33 & 0.31 \\
\hline 7415 & Air conditioning machines & 1,094 & 459,305 & 0.00 & 0.32 & 0.31 \\
\hline 8465 & Corsets and brassieres & 37,057 & 441,126 & 0.11 & 0.30 & 0.20 \\
\hline 0565 & Vegetables, prepared or preserved. & 109,597 & 422,756 & 0.31 & 0.29 & -0.02 \\
\hline 2872 & Nickel ores and concentrates & 145,775 & 420,696 & 0.42 & 0.29 & -0.13 \\
\hline 7852 & Bicycles, not motorized & 1,457 & 407,022 & 0.00 & 0.28 & 0.28 \\
\hline 7642 & Microphones and loudspeakers & 27,321 & 404,327 & 0.08 & 0.28 & 0.20 \\
\hline 7768 & Piezo-electric crystals & 28,753 & 400,004 & 0.08 & 0.28 & 0.19 \\
\hline 7621 & Radio-broadcast receivers for motor & 2,838 & 397,225 & 0.01 & 0.27 & 0.27 \\
\hline 6997 & Articles of iron or steel, nes. & 16,815 & 396,891 & 0.05 & 0.27 & 0.23 \\
\hline 6841 & Aluminum and alloys & 225,990 & 390,521 & 0.65 & 0.27 & -0.38 \\
\hline 3344 & Fuel oils, nes. & $1,561,453$ & 372,788 & 4.46 & 0.26 & -4.20 \\
\hline 6727 & Iron or steel coils & 232,230 & 372,450 & 0.66 & 0.26 & -0.41 \\
\hline 7757 & Electrical domestic appliances & 8,395 & 370,636 & 0.02 & 0.26 & 0.23 \\
\hline 0589 & Fruit otherwise prepared or preserved & 72,953 & 368,587 & 0.21 & 0.25 & 0.05 \\
\hline 0573 & Bananas, fresh or dried & 289,915 & 358,916 & 0.83 & 0.25 & -0.58 \\
\hline 8481 & Articles of apparel \& clothing accessories & 40,604 & 358,489 & 0.12 & 0.25 & 0.13 \\
\hline 0344 & Fish fillets, frozen & 10,453 & 356,309 & 0.03 & 0.25 & 0.22 \\
\hline 7284 & Machines for specialized industries & 13,051 & 352,524 & 0.04 & 0.24 & 0.21 \\
\hline 7711 & Electrical transformers & 73,816 & 335,128 & 0.21 & 0.23 & 0.02 \\
\hline 6911 & Structures \& parts of iron & 758 & 315,483 & 0.00 & 0.22 & 0.22 \\
\hline
\end{tabular}


Appendix Table A5. Continued

\begin{tabular}{cl} 
SITC No. & \multicolumn{1}{c}{ Product Description } \\
66974 & Articles used for domestic purposes \\
6412 & Printing paper \& writing paper \\
8851 & Watches and watch movements \\
5121 & A-cyclic alcohols \\
6716 & Ferro-alloys \\
7518 & Office machines, nes. \\
7499 & Other non-electric parts \& accessories \\
0980 & Edible products and preparations nes
\end{tabular}

ALL ABOVE PRODUCTS

\begin{tabular}{|c|c|c|c|c|}
\hline \multicolumn{2}{|c|}{ Export Values $(\$ 000)$} & \multicolumn{2}{|c|}{ Export Shares \% } & \multirow{2}{*}{$\begin{array}{l}\text { Export } \\
\text { Share } \\
\text { Change }\end{array}$} \\
\hline 1985 & $\underline{2001}$ & $\underline{1985}$ & 2001 & \\
\hline 9,854 & 315,023 & 0.03 & 0.22 & 0.19 \\
\hline 10,211 & 307,235 & 0.03 & 0.21 & 0.18 \\
\hline 125,300 & 292,106 & 0.36 & 0.20 & -0.16 \\
\hline 61,395 & 289,481 & 0.18 & 0.20 & 0.02 \\
\hline 51,302 & 284,961 & 0.15 & 0.20 & 0.05 \\
\hline 1,915 & 284,182 & 0.01 & 0.20 & 0.19 \\
\hline 10,672 & 284,032 & 0.03 & 0.20 & 0.17 \\
\hline 85,948 & 282,651 & 0.25 & 0.19 & -0.05 \\
\hline $25,892,649$ & $114,770,112$ & 73.96 & 79.15 & 5.19 \\
\hline
\end{tabular}

Source: UN COMTRADE statistics. 
Appendix Table A6

East Asia's Largest Four-Digit SITC (Rev. 2) Exports to All Other Destinations

(Totals Exclude Japan and all Regional Countries)

SITC No. Product Description

TOTAL TRADE

7764 Electronic microcircuits

7599 Parts of office machinery

8942 Children s toys and games.

7524 Digital central storage units

7525 Peripheral units \& adapters

8510 Footwear

7643 Radiotelephonic equipment

7810 Passenger motor cars

7638 Other sound recorders

7522 Complete digital data processing machines

8451 Jerseys and pullovers

7641 Electric telephonic \& telegraphic line

8310 Travel goods and handbags

8219 Other furniture and parts

8439 Other outer garments of textile fabric

7649 Parts of telecom equipment

9310 Special transactions

8939 Miscellaneous articles

7788 Other electrical machinery

8459 Other knit outer garments

7712 Other electric power machinery

8124 Lighting fixtures and fittings

7758 Electro-thermal appliances

7628 Other radio-broadcast receivers

7528 Off-line data processing equipment

8211 Chairs and other seats

7721 Electrical switches and relays

3330 Petroleum oils

8462 Under garments of cotton

7611 Color television receivers

7722 Printed circuits and parts

7523 Complete digital processing equipment

8947 Other sporting goods

8429 Other outer garments of textile fabric

7731 Insulated electrical wire

7849 Other parts \& accessories of motor vehicles

7763 Diodes and transistors

8973 Jewellery of gold or silver

7757 Electrical domestic appliances

8481 Apparel \& clothing accessories

8423 Trousers and breeches

8983 Gramophone records

7415 Air conditioning machines

7642 Microphones and loudspeakers

\section{Export Values $(\$ 000)$}

$\underline{1985} \quad \underline{2001}$

$\underline{96,868,507}$

$3,767,804$

$1,940,788$

$3,176,701$

3,775

499,963

$4,363,040$

205,680

46,277

673,100

79,055

$1,981,580$

524,815

$1,797,510$

144,052

$2,096,054$

$1,371,712$

828,694

924,218

838,549

$1,453,389$

376,721

368,089

886,482

926,202

34,361

69,206

360,300

$4,843,947$

739,153

760,313

150,445

206,756

875,608

631,698

431,565

276,805

504,503

543,046

303,264

985,524

991,124

306,507

34,096

291,483

\section{$572,884,033$}

$33,851,396$

$30,882,450$

$22,689,247$

$21,150,427$

$21,033,579$

$20,054,966$

$12,944,357$

$12,461,436$

$10,267,198$

$10,163,693$

$9,778,780$

$8,491,822$

$8,010,007$

$7,934,572$

$7,790,250$

$7,163,547$

$6,824,153$

$6,647,579$

$5,773,110$

$5,667,265$

$5,435,563$

$5,058,851$

$4,968,078$

$4,800,235$

$4,521,606$

$4,473,660$

$4,203,768$

$3,951,801$

$3,840,324$

$3,695,114$

$3,546,071$

$3,535,136$

$3,433,721$

$3,366,823$

$3,356,268$

$3,253,065$

$3,249,291$

$3,223,597$

$3,076,607$

$3,021,234$

$2,931,993$

$2,913,471$

$2,881,335$

$2,788,223$
Export Shares \%

$\underline{1985} \quad \underline{2001}$

100

3.89

2.00

3.28

0.00

0.52

4.50

0.21

0.05

0.69

0.08

2.05

0.54

1.86

0.15

2.16

1.42

0.86

0.95

0.87

1.50

0.39

0.38

0.92

0.96

0.04

0.07

0.37

5.00

0.76

0.78

0.16

0.21

0.90

0.65

0.45

0.29

0.52

0.56

0.31

1.02

1.02

0.32

0.04

0.30
Export

Share

Change

--

2.02

3.39

0.68

3.69

3.16

$-1.00$

2.05

2.13

1.10

1.69

$-0.34$

0.94

$-0.46$

1.24

$-0.80$

$-0.17$

0.34

0.21

0.14

$-0.51$

0.56

0.50

$-0.05$

$-0.12$

0.75

0.71

0.36

$-4.31$

$-0.09$

$-0.14$

0.46

0.40

$-0.30$

$-0.06$

0.14

0.28

0.05

0.00

0.22

$-0.49$

$-0.51$

0.19

0.47

0.19 


\begin{tabular}{|c|c|c|c|c|c|c|}
\hline \multirow[b]{2}{*}{ SITC No. } & \multirow[b]{2}{*}{ Product Description } & \multicolumn{2}{|c|}{ Export Values $(\$ 000)$} & \multicolumn{2}{|c|}{ Share of Exports \% } & \multirow{2}{*}{$\begin{array}{l}\text { Export } \\
\text { Share } \\
\text { Change } \\
\end{array}$} \\
\hline & & $\underline{1985}$ & 2001 & 1985 & 2001 & \\
\hline 8441 & Men's shirts of textile fabrics & $1,478,649$ & $2,734,354$ & 1.53 & 0.48 & -1.05 \\
\hline 0360 & Crustaceans & 373,829 & $2,640,950$ & 0.39 & 0.46 & 0.08 \\
\hline 8482 & Articles of apparel \& clothing accessories & 333,105 & $2,610,124$ & 0.34 & 0.46 & 0.11 \\
\hline 6940 & Iron nails, screws or nuts & 453,678 & $2,592,438$ & 0.47 & 0.45 & -0.02 \\
\hline 6974 & Articles used for domestic purposes, & 386,945 & $2,447,315$ & $0.40^{\circ}$ & 0.43 & 0.03 \\
\hline 7932 & Ships and boats & 505,534 & $2,442,720$ & 0.52 & 0.43 & -0.10 \\
\hline 8811 & Photographic cameras and parts & 246,161 & $2,342,983$ & 0.25 & 0.41 & 0.15 \\
\hline 6531 & Woven fabrics of synthetic thread & 400,503 & $2,266,432$ & 0.41 & 0.40 & -0.02 \\
\hline 8851 & Watches and watch movements & 918,582 & $2,249,557$ & 0.95 & 0.39 & -0.56 \\
\hline 6991 & Locksmiths wares & 305,533 & $2,244,109$ & 0.32 & 0.39 & 0.08 \\
\hline 6552 & Knitted or crocheted fabrics & 80,830 & $2,217,994$ & 0.08 & 0.39 & 0.30 \\
\hline 8931 & Articles for packing goods & 154,848 & $2,202,754$ & 0.16 & 0.38 & 0.22 \\
\hline 8435 & Blouses of textile fabrics & $1,105,656$ & $2,178,960$ & 1.14 & 0.38 & -0.76 \\
\hline 7622 & Radio-broadcast receivers portable. & 848,625 & $2,098,678$ & 0.88 & 0.37 & -0.51 \\
\hline 8999 & Manufactured goods, nes & 443,254 & $1,994,268$ & 0.46 & 0.35 & -0.11 \\
\hline 7621 & Radio-broadcast receivers & 362,848 & $1,920,376$ & 0.37 & 0.34 & -0.04 \\
\hline 6953 & Other hand tools & 400,370 & $1,903,802$ & 0.41 & 0.33 & -0.08 \\
\hline 2320 & Natural rubber latex & $1,640,401$ & $1,839,854$ & 1.69 & 0.32 & -1.37 \\
\hline 7781 & Batteries and accumulators & 143,141 & $1,817,769$ & 0.15 & 0.32 & 0.17 \\
\hline 7492 & Taps, cocks, and valves for pipes & 148,368 & $1,803,174$ & 0.15 & 0.31 & 0.16 \\
\hline 7784 & Tools for working in the hand & 30,096 & $1,736,503$ & 0.03 & 0.30 & 0.27 \\
\hline 7518 & Office machines, nes. & 63,278 & $1,666,686$ & 0.07 & 0.29 & 0.23 \\
\hline 7512 & Calculating machines & 224,078 & $1,649,719$ & 0.23 & 0.29 & 0.06 \\
\hline 7853 & Invalid carriages & 122,116 & $1,645,571$ & 0.13 & 0.29 & 0.16 \\
\hline 8842 & Spectacles and spectacle frames & 241,981 & $1,644,279$ & 0.25 & 0.29 & 0.04 \\
\hline 8710 & Optical instruments and apparatus & 66,904 & $1,635,428$ & 0.07 & 0.29 & 0.22 \\
\hline 6522 & Cotton fabrics, woven & 438,971 & $1,628,092$ & 0.45 & 0.28 & -0.17 \\
\hline 7852 & Bicycles & 309,908 & $1,602,118$ & 0.32 & 0.28 & -0.04 \\
\hline 8720 & Medical instruments and appliances & 95,522 & $1,590,644$ & 0.10 & 0.28 & 0.18 \\
\hline 6960 & Cutlery & 275,116 & $1,563,716$ & 0.28 & 0.27 & -0.01 \\
\hline 8997 & Basketwork & 401,974 & $1,537,049$ & 0.41 & 0.27 & -0.15 \\
\hline 8484 & Headgear and fittings thereof & 230,083 & $1,532,610$ & 0.24 & 0.27 & 0.03 \\
\hline 6589 & Other made-up articles of textile $m$ & 213,805 & $1,527,875$ & 0.22 & 0.27 & 0.05 \\
\hline 6672 & Diamonds & 234,149 & $1,508,847$ & 0.24 & 0.26 & 0.02 \\
\hline 4242 & Palm oil & $1,115,175$ & $1,501,677$ & 1.15 & 0.26 & -0.89 \\
\hline 8921 & Books and pamphlets & 193,529 & $1,482,159$ & 0.20 & 0.26 & 0.06 \\
\hline 7162 & Electrical motors \& generators & 114,985 & $1,430,295$ & 0.12 & 0.25 & 0.13 \\
\hline 7821 & Motor vehicles for transport of goods & 7,852 & $1,399,303$ & 0.01 & 0.24 & 0.24 \\
\hline 6514 & Yarn containing $85 \%$ synthetic fibur & 222,401 & $1,347,880$ & 0.23 & 0.24 & 0.01 \\
\hline 6354 & Domestic manufactures of wood & 272,326 & $1,316,050$ & 0.28 & 0.23 & -0.05 \\
\hline 8465 & Corsets and brassieres & 145,052 & $1,305,064$ & 0.15 & 0.23 & 0.08 \\
\hline 8431 & Coats and jackets of textile fabric & 661,393 & $1,302,918$ & 0.68 & 0.23 & -0.46 \\
\hline 6251 & Tires & 212,359 & $1,301,097$ & 0.22 & 0.23 & 0.01 \\
\hline 6997 & Articles of iron or steel, nes & 227,706 & $1,285,928$ & 0.24 & 0.22 & -0.01 \\
\hline 7782 & Electrical filament lamps & 160,025 & $1,281,035$ & 0.17 & 0.22 & 0.06 \\
\hline 7648 & Telecommunications equipment & 274,430 & $1,231,839$ & 0.28 & 0.22 & -0.07 \\
\hline 0372 & Crustaceans & 205,302 & $1,209,928$ & 0.21 & 0.21 & 0.00 \\
\hline
\end{tabular}


Appendix Table A6. Continued

\begin{tabular}{cl} 
SITC No. & Product Description \\
\hline 6584 & Bed and table linen \\
8433 & Women's dresses \\
6342 & Plywood sheets \\
8972 & Imitation jewellery \\
5156 & Hetero-cyclic compounds \\
5823 & Alkyds and other polyesters \\
7768 & Piezo-electric crystals \\
7284 & Machines for specialized purposes \\
8472 & Clothing accessories, knitted \\
& ALL ABOVE PRODUCTS
\end{tabular}

\begin{tabular}{|c|c|c|c|c|}
\hline \multicolumn{2}{|c|}{ Export Value $(\$ 000)$} & \multicolumn{2}{|c|}{ Share of Exports \% } & $\begin{array}{l}\text { Export } \\
\text { Share }\end{array}$ \\
\hline 1985 & 2001 & $\underline{1985}$ & 2001 & Change \\
\hline 427,708 & $1,185,712$ & 0.44 & 0.21 & -0.23 \\
\hline 382,486 & $1,180,933$ & 0.39 & 0.21 & -0.19 \\
\hline 690,936 & $1,166,016$ & 0.71 & 0.20 & -0.51 \\
\hline 482,015 & $1,147,022$ & 0.50 & 0.20 & -0.30 \\
\hline 120,608 & $1,132,206$ & 0.12 & 0.20 & 0.07 \\
\hline 39,696 & $1,110,004$ & 0.04 & 0.19 & 0.15 \\
\hline 399,173 & $1,062,147$ & 0.41 & 0.19 & -0.23 \\
\hline 136,405 & $1,044,894$ & 0.14 & 0.18 & 0.04 \\
\hline 290,870 & $1,018,400$ & 0.30 & 0.18 & -0.12 \\
\hline $3,075,227$ & $453,565,924$ & 65.11 & 79.17 & 14.06 \\
\hline
\end{tabular}

Source: UN COMTRADE statistics. 
Appendix Table A7

East Asia's Largest Four-Digit SITC (Rev. 2) Exports to ASEAN Markets

\begin{tabular}{|c|c|}
\hline SITC No. & $\frac{\text { Product Description }}{\text { TOTAL TRADE }}$ \\
\hline 7764 & Electronic microcircuits \\
\hline 7524 & Digital central storage units \\
\hline 7599 & Parts of office machinery \\
\hline 7525 & Peripheral units $\&$ adapters \\
\hline 8510 & Footwear \\
\hline 3330 & Petroleum oils \\
\hline 7638 & Other sound recorders \\
\hline 7643 & Radiotelephonic equipment \\
\hline 8451 & Jerseys and pullovers \\
\hline 7641 & Telephonic \& telegraphic line \\
\hline 7522 & Digital data processing machines \\
\hline 9310 & Special transactions \\
\hline 8219 & Other furniture \\
\hline 8439 & Other textile outer garments \\
\hline 7628 & Other radio-broadcast receivers \\
\hline 0360 & Crustaceans \\
\hline 7649 & Parts of telecom equipment \\
\hline 7611 & Color television receivers \\
\hline 7763 & Diodes and transistors \\
\hline 8459 & Other knit outer garments \\
\hline 2320 & Natural rubber latex \\
\hline 7528 & Off-line data processing equipment. \\
\hline 4242 & Palm oil \\
\hline 8482 & Articles of clothing accessories \\
\hline 7712 & Other electric power machinery \\
\hline 7788 & Other electrical machinery and equipment \\
\hline 8973 & Jewellery of gold or silver \\
\hline 8310 & Travel goods and handbags \\
\hline 8211 & Chairs and other seats and parts \\
\hline 8462 & Under garments of cotton \\
\hline 7721 & Electrical switches and relays \\
\hline 7523 & Complete digital central processing \\
\hline 7621 & Radio-broadcast receivers for motor \\
\hline 8423 & Trousers of textile fabric \\
\hline 6342 & Plywood consisting of sheets \\
\hline 8429 & Other outer garments of textiles \\
\hline 7415 & Air conditioning machines \\
\hline 0372 & Crustaceans, prepared \\
\hline 8942 & Children s toys and indoor games. \\
\hline 7731 & Insulated electrical wire \\
\hline 7821 & Motor vehicles for transport of goods \\
\hline 8441 & Men's shirts of textile fabrics \\
\hline 0371 & Fish, prepared or preserved \\
\hline 2483 & Wood of non-coniferous species \\
\hline 0422 & Rice semi-milled or wholly milled, \\
\hline 8720 & Medical instruments and appliances \\
\hline
\end{tabular}

\begin{tabular}{|c|c|c|c|c|}
\hline \multicolumn{2}{|c|}{ Export Value $(\$ 000)$} & \multicolumn{2}{|c|}{ Share of Exports (\%) } & \multirow{2}{*}{$\begin{array}{l}\text { Export } \\
\text { Share } \\
\text { Change } \\
\end{array}$} \\
\hline$\underline{1985}$ & 2001 & 1985 & $\underline{2001}$ & \\
\hline $30,467,224$ & $176,320,781$ & 100.00 & 100.00 & \\
\hline $2,744,942$ & $19,562,977$ & 9.01 & 11.10 & 2.09 \\
\hline 973 & $15,760,433$ & 0.00 & 8.94 & 8.94 \\
\hline 992,401 & $11,439,900$ & 3.26 & 6.49 & 3.23 \\
\hline 168,514 & $6,579,090$ & 0.55 & 3.73 & 3.18 \\
\hline 126,080 & $5,117,799$ & 0.41 & 2.90 & 2.49 \\
\hline $3,423,297$ & $3,805,147$ & 11.24 & 2.16 & -9.08 \\
\hline 93,470 & $3,689,712$ & 0.31 & 2.09 & 1.79 \\
\hline 26,977 & $2,893,647$ & 0.09 & 1.64 & 1.55 \\
\hline 131,419 & $2,694,439$ & 0.43 & 1.53 & 1.10 \\
\hline 39,751 & $2,687,202$ & 0.13 & 1.52 & 1.39 \\
\hline 15,695 & $2,589,377$ & 0.05 & 1.47 & 1.42 \\
\hline 288,520 & $2,537,726$ & 0.95 & 1.44 & 0.49 \\
\hline 36,095 & $2,424,683$ & 0.12 & 1.38 & 1.26 \\
\hline 289,483 & $2,417,848$ & 0.95 & 1.37 & 0.42 \\
\hline 174,972 & $2,116,440$ & 0.57 & 1.20 & 0.63 \\
\hline 193,188 & $2,054,453$ & 0.63 & 1.17 & 0.53 \\
\hline 399,832 & $1,996,794$ & 1.31 & 1.13 & -0.18 \\
\hline 226,023 & $1,951,955$ & 0.74 & 1.11 & 0.37 \\
\hline 280,414 & $1,941,438$ & 0.92 & 1.10 & 0.18 \\
\hline 161,222 & $1,886,344$ & 0.53 & 1.07 & 0.54 \\
\hline 1636,194 & $1,836,166$ & 5.37 & 1.04 & -4.33 \\
\hline 8,358 & $1,793,374$ & 0.03 & 1.02 & 0.99 \\
\hline $1,091,180$ & $1,500,634$ & 3.58 & 0.85 & -2.73 \\
\hline 61,489 & $1,492,246$ & 0.20 & 0.85 & 0.64 \\
\hline 38,749 & $1,410,630$ & 0.13 & 0.80 & 0.67 \\
\hline 264,490 & $1,371,270$ & 0.87 & 0.78 & -0.09 \\
\hline 274,050 & $1,330,524$ & 0.90 & 0.75 & -0.14 \\
\hline 40,740 & $1,308,680$ & 0.13 & 0.74 & 0.61 \\
\hline 31,156 & $1,286,372$ & 0.10 & 0.73 & 0.63 \\
\hline 151,607 & $1,253,061$ & 0.50 & 0.71 & 0.21 \\
\hline 110,645 & $1,149,969$ & 0.36 & 0.65 & 0.29 \\
\hline 4,525 & $1,097,895$ & 0.01 & 0.62 & 0.61 \\
\hline 91,656 & $1,089,381$ & 0.30 & 0.62 & 0.32 \\
\hline 156,088 & $1,077,721$ & 0.51 & 0.61 & 0.10 \\
\hline 509,364 & $1,060,208$ & 1.67 & 0.60 & -1.07 \\
\hline 33,059 & $1,041,638$ & 0.11 & 0.59 & 0.48 \\
\hline 23,404 & $1,013,941$ & 0.08 & 0.58 & 0.50 \\
\hline 136,353 & $1,011,964$ & 0.45 & 0.57 & 0.13 \\
\hline 201,670 & 994,062 & 0.66 & 0.56 & -0.10 \\
\hline 34,624 & 974,509 & 0.11 & 0.55 & 0.44 \\
\hline 1,056 & 971,700 & 0.00 & 0.55 & 0.55 \\
\hline 222,075 & 861,982 & 0.73 & 0.49 & -0.24 \\
\hline 252,257 & 836,694 & 0.83 & 0.47 & -0.35 \\
\hline 741,446 & 733,705 & 2.43 & 0.42 & -2.02 \\
\hline 241,410 & 704,146 & 0.79 & 0.40 & -0.39 \\
\hline 66,175 & 666,538 & 0.22 & 0.38 & 0.16 \\
\hline
\end{tabular}




\begin{tabular}{|c|c|}
\hline SITC No. & Product Description \\
\hline 7722 & Printed circuits and parts thereof \\
\hline 5156 & Hetero-cyclic compounds \\
\hline 7810 & Passenger motor cars \\
\hline 0711 & Coffee \\
\hline 8435 & Blouses of textile fabrics \\
\hline 8465 & Corsets and brassieres \\
\hline 0589 & Fruit otherwise prepared \\
\hline 7642 & Microphones and loudspeakers \\
\hline 5157 & Sulfa compounds \\
\hline 2871 & Copper ores \\
\hline 8939 & Miscellaneous articles \\
\hline 8811 & Photographic cameras and parts \\
\hline 7768 & Piezo-electric crystals \\
\hline 4243 & Coconut (copra) oil \\
\hline 9710 & Non-Monetary gold \\
\hline 8983 & Gramophone records \\
\hline 5146 & Oxygen-function compounds \\
\hline 8931 & Articles for packing goods \\
\hline 7758 & Electro-thermal appliances. \\
\hline 8743 & Measuring appliances \\
\hline 8710 & Optical instruments and apparatus \\
\hline 6353 & Builders' carpentry products \\
\hline 3222 & Other coal \\
\hline 6514 & Yarn of synthetic fiber \\
\hline 7849 & Other parts of motor vehicles \\
\hline 6531 & Woven synthetic fabrics \\
\hline 5823 & Alkyds and other polyesters \\
\hline 8947 & Other sporting goods \\
\hline 5989 & Chemical products and preparations, nes \\
\hline 5154 & Organic-sulfur compounds \\
\hline 6354 & Manufactures of wood for domestic use \\
\hline 8851 & Watches and watch movements \\
\hline 7781 & Batteries and accumulators \\
\hline 6612 & Portland cement \\
\hline 7149 & Parts of the engines \& motors, nes \\
\hline 7162 & Electric motors \& generators \\
\hline 6672 & Diamonds \\
\hline 0149 & Other prepared or preserved meat \\
\hline 8748 & Electrical measuring equipment \\
\hline 6974 & Domestic use articles \\
\hline 8921 & Books and pamphlets \\
\hline 8433 & Women's dresses \\
\hline 6412 & Printing paper \\
\hline 4244 & Palm kernel oil \\
\hline 5121 & Alcohols \\
\hline 3344 & Fuel oils, nes. \\
\hline 2890 & Ores of precious metals \\
\hline
\end{tabular}

\begin{tabular}{|c|c|c|c|c|}
\hline \multicolumn{2}{|c|}{ Export Value $(\$ 000)$} & \multicolumn{2}{|c|}{ Share of Exports (\%) } & \multirow{2}{*}{$\begin{array}{l}\text { Export } \\
\text { Share } \\
\text { Change }\end{array}$} \\
\hline$\underline{1985}$ & 2001 & $\underline{1985}$ & 2001 & \\
\hline 36,216 & 660,175 & 0.12 & 0.37 & 0.26 \\
\hline 73,169 & 657,173 & 0.24 & 0.37 & 0.13 \\
\hline 420 & 653,452 & 0.00 & 0.37 & 0.37 \\
\hline 502,431 & 650,369 & 1.65 & 0.37 & -1.28 \\
\hline 175,212 & 598,441 & 0.58 & 0.34 & -0.24 \\
\hline 61,335 & 595,571 & 0.20 & 0.34 & 0.14 \\
\hline 308,442 & 579,511 & 1.01 & 0.33 & -0.68 \\
\hline 22,259 & 570,156 & 0.07 & 0.32 & 0.25 \\
\hline 16 & 551,423 & 0.00 & 0.31 & 0.31 \\
\hline 78 & 522,705 & 0.00 & 0.30 & 0.30 \\
\hline 41,203 & 504,072 & 0.14 & 0.29 & 0.15 \\
\hline 16,924 & 503,072 & 0.06 & 0.29 & 0.23 \\
\hline 275,893 & 495,900 & 0.91 & 0.28 & -0.62 \\
\hline 511,278 & 495,091 & 1.68 & 0.28 & -1.40 \\
\hline 36,387 & 486,554 & 0.12 & 0.28 & 0.16 \\
\hline 30,440 & 481,246 & 0.10 & 0.27 & 0.17 \\
\hline 20,061 & 472,182 & 0.07 & 0.27 & 0.20 \\
\hline 37,858 & 466,676 & 0.12 & 0.26 & 0.14 \\
\hline 196,482 & 465,516 & 0.64 & 0.26 & -0.38 \\
\hline 15,333 & 454,283 & 0.05 & 0.26 & 0.21 \\
\hline 6,034 & 447,768 & 0.02 & 0.25 & 0.23 \\
\hline 40,818 & 426,881 & 0.13 & 0.24 & 0.11 \\
\hline 141 & 424,692 & 0.00 & 0.24 & 0.24 \\
\hline 37,533 & 423,539 & 0.12 & 0.24 & 0.12 \\
\hline 33,288 & 423,097 & 0.11 & 0.24 & 0.13 \\
\hline 14,779 & 412,161 & 0.05 & 0.23 & 0.19 \\
\hline 919 & 395,646 & 0.00 & 0.22 & 0.22 \\
\hline 11,062 & 393,187 & 0.04 & 0.22 & 0.19 \\
\hline 31,539 & 388,309 & 0.10 & 0.22 & 0.12 \\
\hline 434 & 372,990 & 0.00 & 0.21 & 0.21 \\
\hline 43,305 & 370,153 & 0.14 & 0.21 & 0.07 \\
\hline 97,139 & 369,941 & 0.32 & 0.21 & -0.11 \\
\hline 40,279 & 367,815 & 0.13 & 0.21 & .0 .08 \\
\hline 34,700 & 360,741 & 0.11 & 0.20 & 0.09 \\
\hline 61,087 & 359,965 & 0.20 & 0.20 & 0.00 \\
\hline 23,506 & 359,889 & 0.08 & 0.20 & 0.13 \\
\hline 47,471 & 357,218 & 0.16 & 0.20 & 0.05 \\
\hline 920 & 353,234 & 0.00 & 0.20 & 0.20 \\
\hline 35,341 & 352,952 & 0.12 & 0.20 & 0.08 \\
\hline 5,194 & 344,395 & 0.02 & 0.20 & 0.18 \\
\hline 47,817 & 334,606 & 0.16 & 0.19 & 0.03 \\
\hline 54,719 & 332,814 & 0.18 & 0.19 & 0.01 \\
\hline 1,458 & 324,755 & 0.00 & 0.18 & 0.18 \\
\hline 279,167 & 323,282 & 0.92 & 0.18 & -0.73 \\
\hline 29,306 & 320,893 & 0.10 & 0.18 & 0.09 \\
\hline 915,020 & 316,956 & 3.00 & 0.18 & -2.82 \\
\hline 2,328 & 312,334 & 0.01 & 0.18 & 0.17 \\
\hline
\end{tabular}


Appendix Table A7. Continued

\begin{tabular}{cl} 
SITC No. & Product Description \\
\hline 7512 & Calculating machines \\
0980 & Edible products and preparations nes \\
6415 & Paper and paperboard \\
8996 & Orthopedic appliances \\
8431 & Coats and jackets of textile fabric \\
7723 & Electrical resistors \\
7518 & Office machines nes
\end{tabular}

\begin{tabular}{cc}
\multicolumn{2}{c}{ Export Value $(\$ 000)$} \\
$\frac{1985}{23,299}$ & $\underline{2001}$ \\
34,000 & 299,556 \\
1,895 & 292,628 \\
1,763 & 288,129 \\
103,330 & 285,709 \\
15,751 & 283,043 \\
4,330 & 282,105
\end{tabular}

Share of Exports (\%)

$\underline{1985} \quad \underline{2001}$

Export

2001 Change

$\begin{array}{lll}0.08 & 0.17 & 0.09\end{array}$

$\begin{array}{lll}0.11 & 0.17 & 0.05\end{array}$

$\begin{array}{lll}0.01 & 0.17 & 0.16\end{array}$

$\begin{array}{lll}0.01 & 0.16 & 0.16\end{array}$

$\begin{array}{lll}0.34 & 0.16 & -0.18\end{array}$

7518 Office machines nes

Source: UN COMTRADE statistics. 

Policy Research Working Paper Series

Title

WPS3056 Avoiding the Pitfalls in Taxing

Financial intermediation

WPS3057 Teaching Adults to Read Better arid Faster: Results from an Experiment in Burkina Faso

WPS3058 Working for God? Evaluating Service Delivery of Religious Not-for-Profit Health Care Providers in Uganda

WPS3059 Do Capital Flows Respond to Risk and Return?

WPS3060 World Market integration through the Lens of Foreign Direct Investors

WPS3061 Reciprocity in Free Trade Agreements

WPS3062 Labor Effects of Adult Mortality in Tanzanian Households

WPS3063 Trade Liberalization, Firm Performance, and Labor Market Outcomes in the Developing World: What Can We Learn from Micro-Level Data?

WPS3064 Trade Policy, Trade Volumes, and Plant-Level Productivity in Colombian Manufacturing Industries

WPS3065 Ghost Doctors: Absenteeism in Bangladeshi Health Facilities

WPS3066 The Potential Demand for and Strategic Use of an HIV-1 Vaccine in Southern India

Ana M. Fernandes

Norman Loayza

Luis Servén

Rui Albuquerque

Norman Loayza

Luis Servén

Caroline Freund

Kathleen Beegle

Paolo Epifani

May 2003

May 2003

May 2003

May 2003

Contact

for paper

Date

May 2003

May 2003

May 2003

May 2003

T. Tourougui

87431

T. Tourougui

87431

P. Flewitt 32724

E. de Castro 89121

P. Flewitt 32724

May 2003

May 2003

Nazmul Chaudhury

Jeffrey S. Hammer

Shreelata Rao Seshadri

P. Subramaniyam

Prabhat Jha

WPS3067 The Mini-Integrated Macroeconomic Pierre-Richard Agénor Model for Poverty Analysis: A Framework for Analyzing the Unemployment and Poverty Effects of Fiscal and Labor Market Reforms

WPS3068 Poverty and Economic Growth in Egypt, 1995-2000

Heba El-laithy

Michael Lokshin

Arup Banerji

WPS3069 International Migration, Remittarices, Richard H. Adams, Jr. and the Brain Drain: A Study of 24 Labor-Exporting Countries

WPS3070 Are You Satisfied? Citizen Feedlsack and Delivery of Urban Services
Uwe Deichmann

Somik V. Lall
June 2003

P. Sader 33902

June 2003

N. Obias 31986

June 2003
A. Fernandes 33983

H. Sladovich 37698

H. Sladovich 37698

M. Gosiengfiao 33363

Y. D'Souza

31449 
Title

WPS3071 Survey Techniques to Measure and Explain Corruption

WPS3072 Diversity Matters: The Economic Geography of Industry Location in India

WPS3073 Metropolitan Industrial Clusters: Patterns and Processes

WPS3074 The Gender Impact of Pension Reform: A Cross-Country Analysis

WPS3075 Child Labor, Income Shocks, and Access to Credit

WPS3076 Trade Reform in Vietnam: Opportunities with Emerging Challenges

WPS3077 Do More Transparent Governments Govern Better?

WPS3078 Regional Integration in East Asia: Challenges and OpportunitiesPart I: History and Institutions

WPS3079 Regional Integration in East Asia: Challenges and OpportunitiesPart II: Trade, Finance, and Integration

WPS3080 Can Fiscal Rules Help Reduce Macroeconomic Volatility in the Latin America and Caribbean Region?

WPS3081 The Anatomy of a Multiple Crisis: Why was Argentina Special and What Can We Learn from It?

WPS3082 Financial Dollarization and Central Bank Credibility

Guillermo Perry

Guillermo Perry

Luis Servén

Kevin Cowan

Quy-Toan Do

Michael Haney

WPS3083 Mine Closure and its Impact on the Community: Five Years after Mine Maria Shkaratan

Jun KoO

Estelle James

Rebeca Wong

Roberta Gatti

Philippe Auffret

Roumeen Islam
Date

Contact

for paper

Alejandra Cox Edwards

Kathleen Beegle

Rajeev H. Dehejia

Eisuke Sakakibara

Eisuke Sakakibara Sharon Yamakawa Closure in Romania, Russia, and Ukraine
June 2003

June 2003

June 2003

$\begin{array}{ll}\text { June 2003 } & \begin{array}{l}\text { H. Sladovich } \\ 37698\end{array} \\ \text { June 2003 } & \begin{array}{l}\text { V. Soukhanov } \\ 35721\end{array} \\ & \\ \text { June 2003 } & \text { V. Soukanov } \\ & 35721\end{array}$

June 2003

M. Ponglumjeak 31060

June 2003

June 2003

June 2003

June 2003

E. de Castro 89121

K. Tomlinson 39763

R. Islam 32628

S. Yusuf 82339

June 2003

S. Yusuf 82339

June 2003

R. Izquierdo 84161

June 2003

A. Izquierdo 84161

June 2003

Q. Do 34813

June 2003

\section{Marquez} 36578 